\title{
Public-Private partnerships and sustainable development in the European Union
}

Citation for published version (APA):

Aschieri, A. (2018). Public-Private partnerships and sustainable development in the European Union: Another reason to foster the promotion of PPPs as viable alternatives in the delivery of public services and infrastructure. [Doctoral Thesis, Maastricht University]. Datawyse / Universitaire Pers Maastricht. https://doi.org/10.26481/dis.20180207aa

Document status and date:

Published: 01/01/2018

DOI:

10.26481/dis.20180207aa

Document Version:

Publisher's PDF, also known as Version of record

\section{Please check the document version of this publication:}

- A submitted manuscript is the version of the article upon submission and before peer-review. There can be important differences between the submitted version and the official published version of record.

People interested in the research are advised to contact the author for the final version of the publication, or visit the DOI to the publisher's website.

- The final author version and the galley proof are versions of the publication after peer review.

- The final published version features the final layout of the paper including the volume, issue and page numbers.

Link to publication

\footnotetext{
General rights rights.

- You may freely distribute the URL identifying the publication in the public portal. please follow below link for the End User Agreement:

www.umlib.nl/taverne-license

Take down policy

If you believe that this document breaches copyright please contact us at:

repository@maastrichtuniversity.nl

providing details and we will investigate your claim.
}

Copyright and moral rights for the publications made accessible in the public portal are retained by the authors and/or other copyright owners and it is a condition of accessing publications that users recognise and abide by the legal requirements associated with these

- Users may download and print one copy of any publication from the public portal for the purpose of private study or research.

- You may not further distribute the material or use it for any profit-making activity or commercial gain

If the publication is distributed under the terms of Article $25 \mathrm{fa}$ of the Dutch Copyright Act, indicated by the "Taverne" license above, 


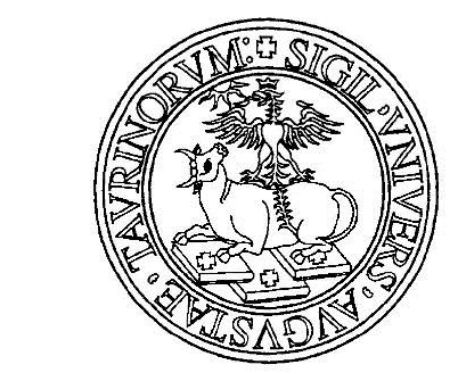

UNIVERSITA DEGLI STUDI DI TORINO

\section{Duastricht University in Leaning!}

\section{Public-Private Partnerships and Sustainable Development in the European Union}

Another Reason to Foster the Promotion of PPPs as Viable Alternatives in the Delivery of Public Services and Infrastructure

to obtain the degree of Doctor by the University of Turin on the authority of the Rector Magnificus, Professor Gianmaria Ajani, and the degree of Doctor by Maastricht University, on the authority of the Rector Magnificus,

Professor Rianne M. Letschert, in accordance with the decision of Board of Deans, to be defended in public on Wednesday $7^{\text {th }}$ of February 2018 at 16:00 hours in Maastricht

by

Annalisa Aschieri 
First Supervisor:

Prof. Hildegard Schneider, Maastricht University

Second Supervisor:

Prof. Roberto Caranta, Università degli Studi di Torino

Co-supervisor:

Dr. Sarah Schoenmaekers, Maastricht University

Assessment Committee:

Chairman, Prof. Dr. Michael Faure, Maastricht University

Prof. Dr. Niels Philipsen, Maastricht University

Prof. Mario Comba, Università degli Studi di Torino

Prof. Mariano Protto, Università degli Studi di Torino

Prof. Christopher Bovis, University of Hull

Dr. Martina Conticelli, Università degli Studi di Roma Tor Vergata 


\title{
Public-Private Partnerships and Sustainable Development in the European Union
}

\author{
Another Reason to Foster the Promotion of PPPs as Viable Alternatives in the \\ Delivery of Public Services and Infrastructure
}

This thesis discusses the ability of Public-Private Partnerships (hereinafter PPPs) to generate socioenvironmental benefits, thus, their capability to promote sustainable development goals throughout Europe.

In the ongoing process of boosting growth within the European Union, it is crucial to acknowledge that PPPs could be used as effective public delivery means of both economic and socio-environmental gains. Not only the functioning of the Internal Market could be fostered through PPPs, but also other equally important goals of sustainable development could be effectively pursued.

This thesis will preliminarily provide an understanding of the PPP phenomenon as a whole, its legal background and implementation in the Member States studied. Then, the relationship between the concept of sustainable development and public procurement will be examined in order to subsequently delve into the study of PPPS' ability to generate socio-environmental benefits. Furthermore, the scope for sustainable development in the European public contracts and concessions law will be outlined so as to identify the possible spaces for sustainability considerations in PPPS' structures. Next, PPPs' potential socioenvironmental benefits will be investigated. Then, it will be studied the scope for sustainable development considerations within domestic policies and relevant public contracts and concessions law regimes of the Member States studied. Thereafter, national representative PPP projects will be identified and case studies will be carried out. Such empirical study will highlight, inter alia, the specific socio-environmental benefits delivered as well as the tender and contractual strategies, inherent in the particular structure of the PPPS studied, which allowed the integration and the generation, along with economic gains, of sustainable benefits. Thus, this study will identify the concrete ways through which sustainable development goals were promoted in the PPPs studied. Lastly, an overview of the research carried out and a picture of the acknowledgments and achievements of this thesis, along with concluding findings and remarks, will be provided.

Therefore, this study recognises PPPs as key elements, not only for the functioning of the Internal Market, but also for the promotion of sustainable development goals, such as social justice issues and shared environmental policy purposes. These may range from climate change concerns and the promotion of energy savings, to alternative energy sources or from energy and resource efficiency, development and environmental sustainability, to high-quality level of public services and infrastructure.

Overall, this thesis argues that, especially in the light of the current European contingencies, the generation of socio-environmental benefits represents another important reason why PPPs should be broadly exploited throughout the European Union as viable alternatives in the delivery of public services and/or infrastructure. 


\section{ACKNOWLEDGEMENTS}

I want to thank Professor Sue Arrowsmith, University of Nottingham, UK, Dr. Ping Wang, University of Nottingham, UK, Dr. Baudouin Heuninckx, University of Nottingham, UK, Professor Peter Kunzlik, University of East Anglia, UK, Professor John Linarelli, Swansea University, UK, Dr. Albert Sanchez Graells, University of Bristol, UK, Professor Martin Trybus, University of Birmingham, UK, Dr. Pedro Telles, Swansea University, UK, as well as all the academic staff of the PPRG for their insightful comments on my research project.

Moreover, I would like to thank Mr. David Szuminski, Housing Manager, Plymouth Grove project, Mr. Niklas Franck, Skanska Infrastructure Development, Mr. Wop Schat and Mr. Leon Kneepkens, A12 Project Managers, Mr. Leendert Van Geldermalsen and Mr. Arno Eversdijk, Rijkswaterstaat, Mr. Michiel de Beer, N33 Project Manager, Mr. René Bartels, Project Manager, Municipality of Eindhoven, Mr. Alberto Eichholzer, Compagnia di San Paolo, Mrs. Giusi di Bartolo, Project Manager, TRM S.p.A., Mr. Giorgio Gallesio, DE-GA S.p.A., Mr. Sandro Perrone, SDB shareholder, Mr. Paolo Badino, Intesa San Paolo, Mr. Roberto Rocchietti, Ivrea 24 Abitare Sostenibile S.p.A., Ms. Valentina Gallia, Project Manager, Sharing S.r.l., for their precious support in the research and study of the national PPP projects presented in this thesis.

I would then like to thank my supervisors Professor Hildegard Schneider and Professor Sarah Schoenmaekers, University of Maastricht, The Netherlands, for their valuable support and advice throughout this research, which helped me to mould my thoughts and arouse my interest in this fascinating area of law.

Finally yet importantly, I am particularly grateful to my supervisor Professor Roberto Caranta, University of Torino, Italy, for his confidence, encouragement and constant support during my every-day research and drafting of this thesis.

All mistakes are mine.

Annalisa Aschieri

Ph.D. Candidate

Department of Law

University of Torino, Italy

University of Maastricht, The Netherlands 


\section{LIST OF ABBREVIATIONS}

CCR 2016 Concession Contracts Regulations 2016

CJEU Court of Justice of the European Union

CPN Competitive Procedure with Negotiation

CPV Common Procurement Vocabulary

DPA Dutch Procurement Act

DPS Dynamic Purchasing System

ECI Environmental Cost Indicator

EEA European Economic Area

ELCC Environmental Life Cycle Costing

ESI International School of Eindhoven

ESPD European Single Procurement Document

EU European Union

EU law European law

GPA Government Procurement Agreement

ILO International Labour Organization

IMF International Monetary Fund

LCA Life Cycle Assessment

LCC Life Cycle Costing

MEAT Most Economically Advantageous Tender

MIRT Multiyear Programme for Infrastructure, Spatial Planning and Transport

NL Netherlands

OJEU Official Journal of the European Union

PCR 2015 Public Contracts Regulations 2015

PIN Prior Information Notice

PFI Private Finance Initiative

PF2 Private Finance 2

PPC Public-Private Comparator

IPPP Institutionalised Public-Private Partnerships

PPC Public-Private Comparator

PPPs Public-Private Partnerships

PPS Publiek-Private Samenwerking

PSC Public Sector Comparator

RWS Rijkswaterstaat

SME Small and Medium Size Enterprises

SPV Special Purpose Vehicle

TFEU Treaty on the functioning of the European Union

TTIP Transatlantic Trade and Investment Partnership

VfM Value for Money

UNICITRAL United Nations Commission on International Trade law

UK United Kingdom

US United States

WTO World Trade Organization 


\section{LIST OF FIGURES AND TABLES}

Figure 1 Types of private sector involvement

Figure 2 Country breakdown by value and number of transactions

Figure 3 PPS phases

Figure 4 The concept of sustainable development

Figure 5 Sustainable public procurement

Figure 6 Project 2002 PFI structure

Figure 7 The p-p-p triangle

Figure 8 The monetization of environmental impacts

Figure 9 The functioning of DuboCalc tool

Figure 10 The selection of the best bid

Figure 11 The A12 highway

Figure 12 The ISE buildings

Figure 13 The ISE courtyard

Figure 14 The ISE buildings, chart.

Table 1 Procurement schemes falling or not within the PPP notion

Table 2 Procedures available

Table 3 Competitive procedure with negotiation

Table 4 Competitive dialogue procedure

Table 5 Innovation partnership procedure

Table 6 Design contest procedure

Table 7 EU Environmental legislation

Table 8 EU Social legislation

Table 9 Measures that can support the integration of sustainability in PPPs

Table 10 Socio-environmental benefits generated by the Plymouth Grove PFI project

Table 11 Socio-environmental benefits generated by the Barts and the London Hospitals

Table 12 Socio-environmental benefits generated by the Glasgow Schools Project

Table 13 Socio-environmental benefits generated by the A12 project

Table 14 Socio-environmental benefits generated by the N33 project

Table 15 Socio-environmental benefits generated by the International School of Eindhoven project

Table 16 Socio-environmental benefits generated by the Ivrea 24 project.

Table 17 Socio-environmental benefits generated by the TRM project

Table 18 Socio-environmental benefits generated by the Scuola di Biotecnologie project

Table 19 Inclusion of sustainable development considerations into PPPs

Table $20 \quad$ United Kingdom's case studies

Table 21 The Netherlands' case studies

Table 22 Italy's case studies

Table 23 Inclusion of sustainable development considerations into PPPs 


\section{TABLE OF CONTENTS}

ICHAPTER-INTRODUCTION

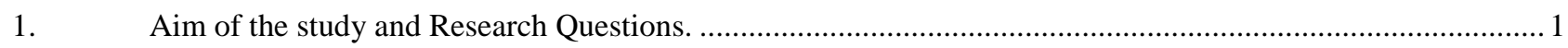

2. Definitions and Summary of the Literature Review. …….....................................................................

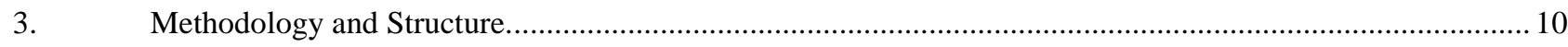

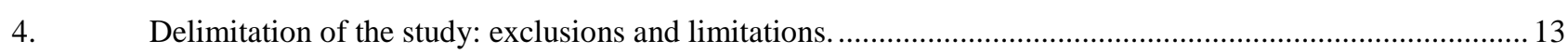

5. 'Brexit' and its possible implications on the UK's public procurement market and legal regime................... 16

II CHAPTER - PUBLIC-PRIVATE PARTNERSHIPS .....................................................................................................................................18

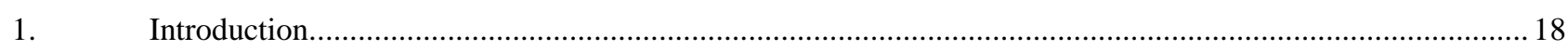

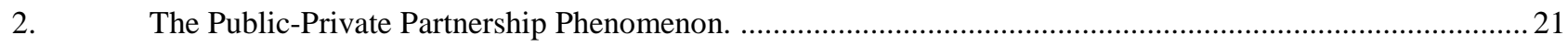

2.1. Public-Private Partnership's Definition at an International Level. .................................................................. 23

2.2. The Definition of Public-Private Partnerships at the European Level. ............................................................ 27

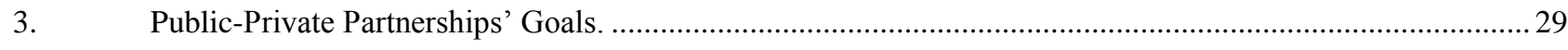

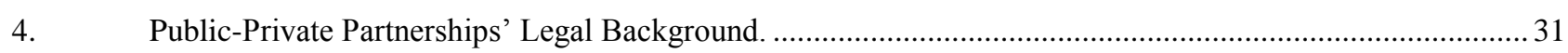

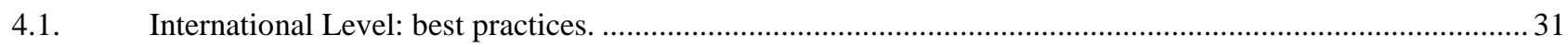

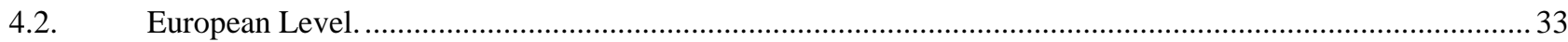

4.2.1 The absence of a uniform regulation: PPPs governed by the Treaty principles and EU public contracts and

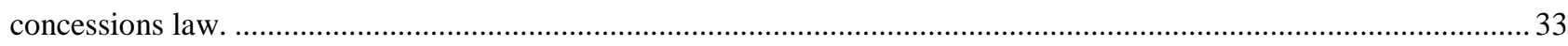

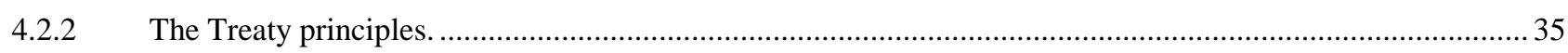

4.2.3 EU Soft Law: Interpretative Communications, Resolutions and Green Papers............................................... 39

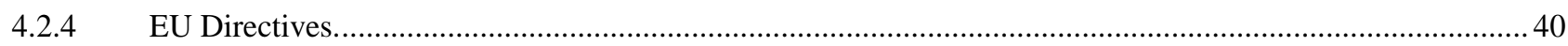

4.2.4.1 Public contracts' award procedures and relevant 2014 changes: general overview....................................... 42

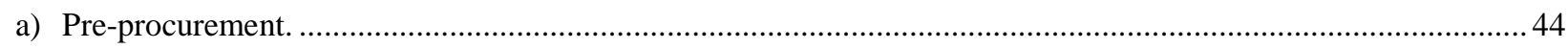

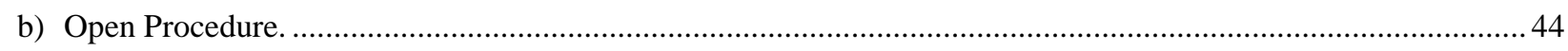

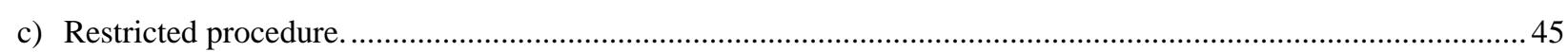

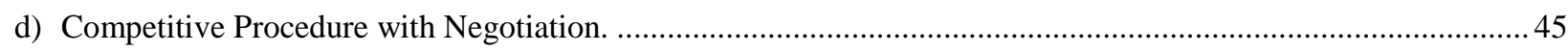

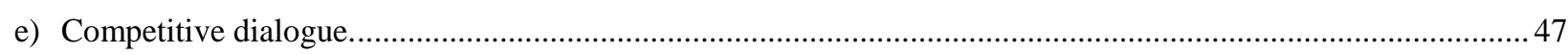

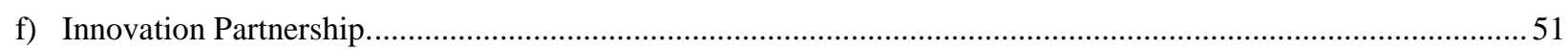

g) Negotiated Procedure without Prior Publication. ........................................................................................52

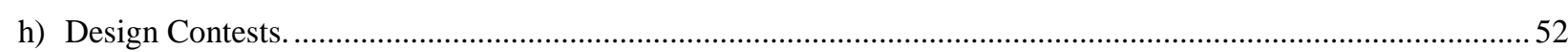

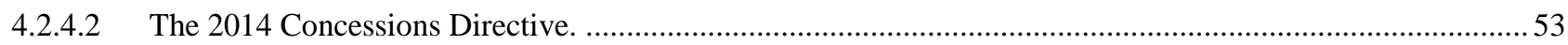

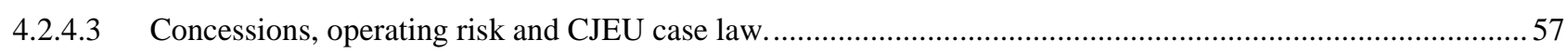

5. Public-Private Partnerships in the selected Member States. ........................................................................62

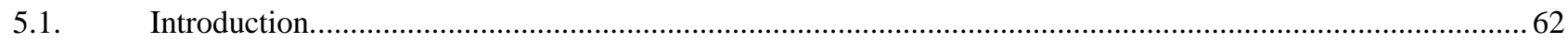

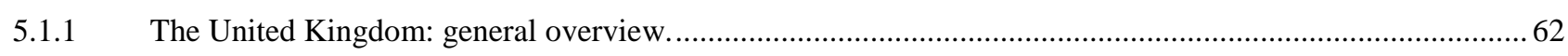

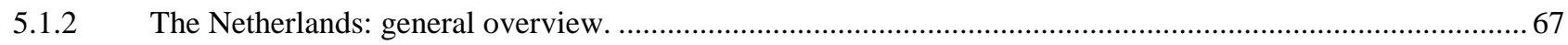

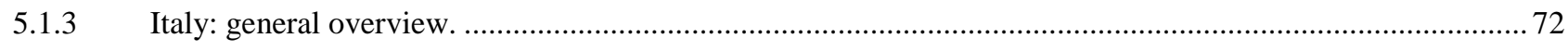

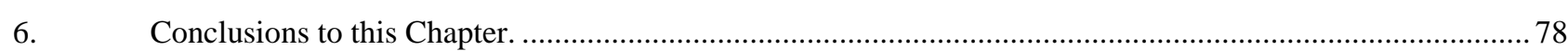

III CHAPTER - PUBLIC-PRIVATE PARTNERSHIPS AND SUSTAINABLE DEVELOPMENT IN THE EUROPEAN

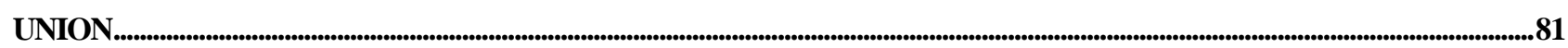

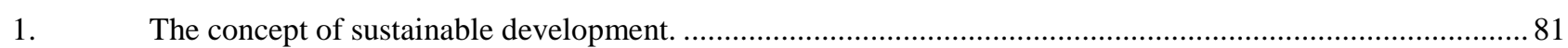




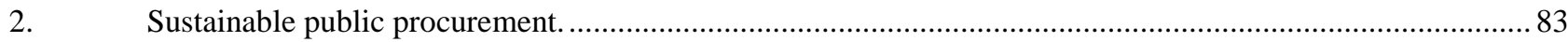

3. The scope for sustainable development in EU public contracts and concession law................................... 85

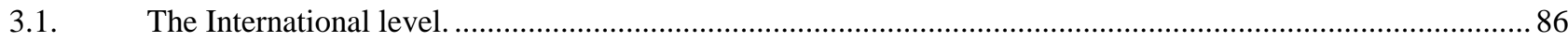

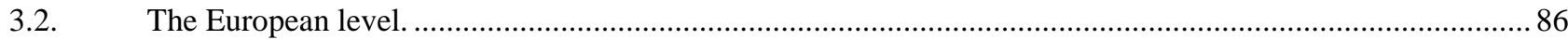

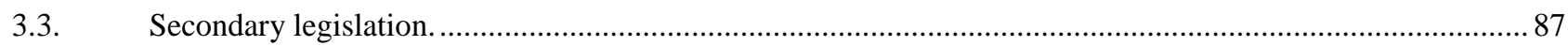

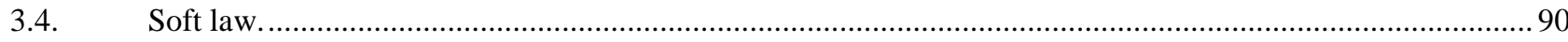

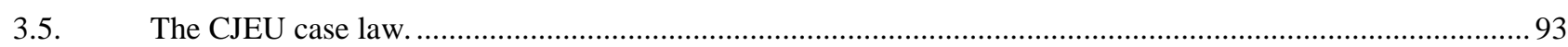

3.6. The Scope for sustainable development in the 2014 public procurement Directives. .................................. 97

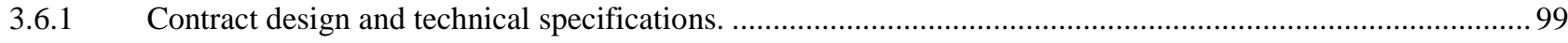

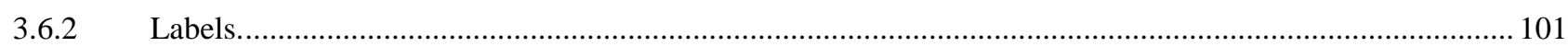

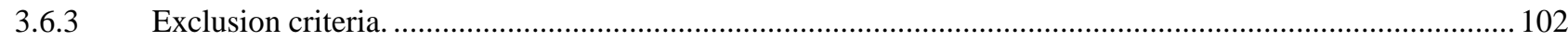

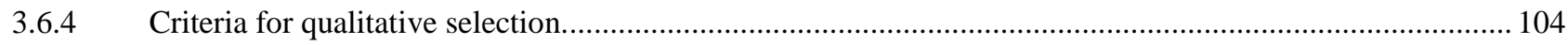

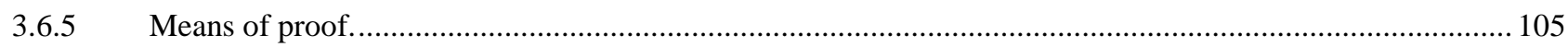

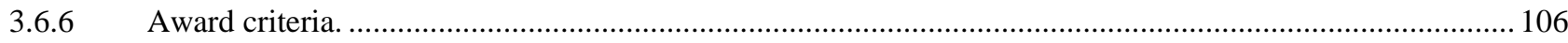

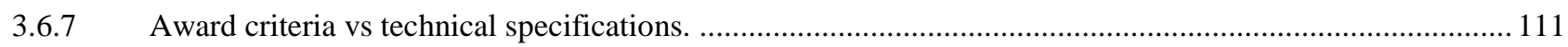

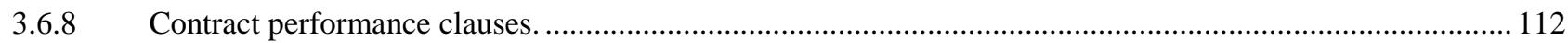

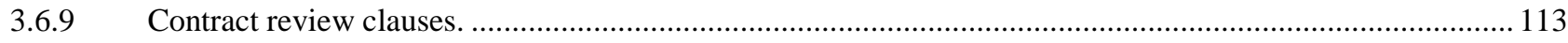

4. The scope for sustainable development concerns in public-private partnerships. ......................................113

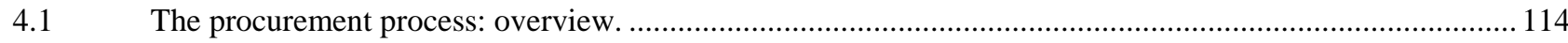

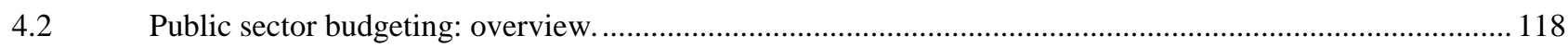

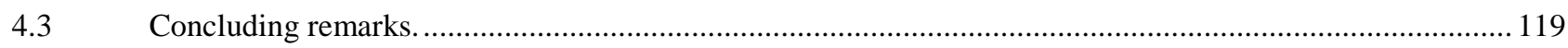

5. Public-Private Partnerships's socio-environmental benefits. ........................................................... 120

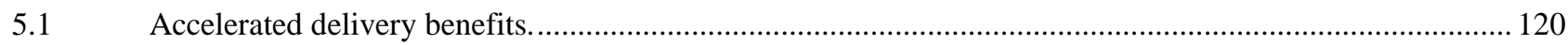

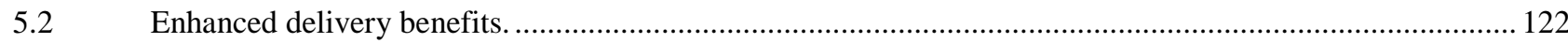

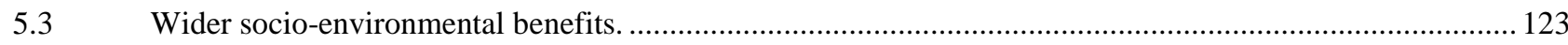

The open issue of measurement of socio-environmental benefits. ........................................................ 123

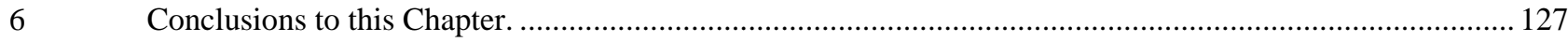

IV CHAPTER - MEMBER STATES' EXPERIENCE: THE UNITED KINGDOM, THE NETHERLANDS AND ITALY 130

1 Introduction

130

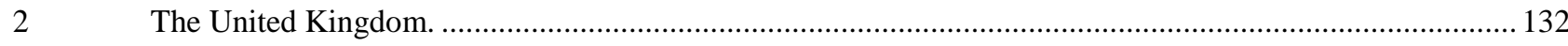

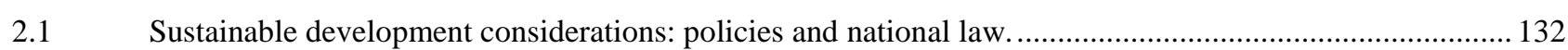

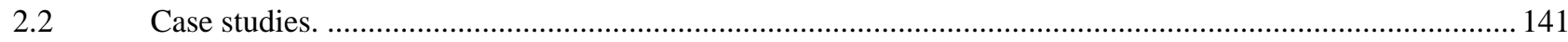

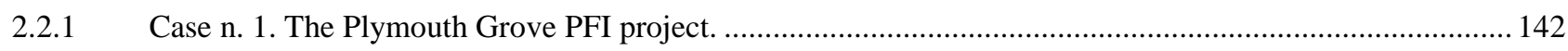

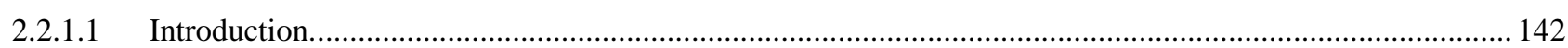

2.2.1.2 Socio-environmental benefits generated by the Plymouth Grove PFI project. ...................................... 143

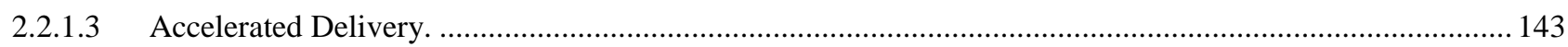

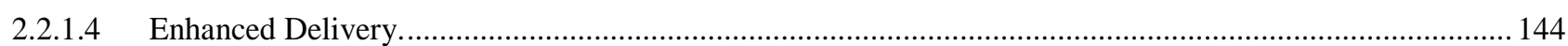

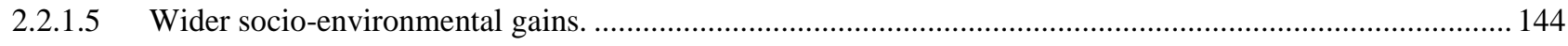

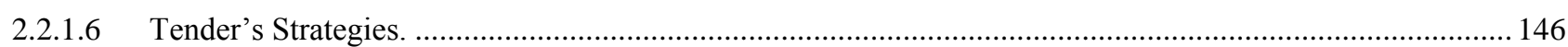

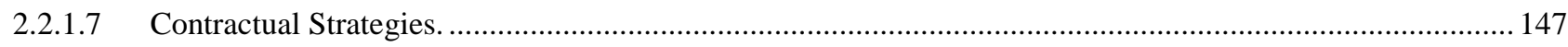

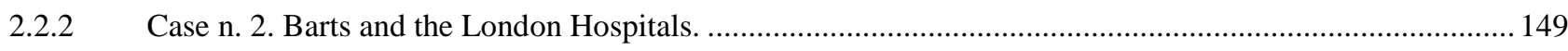




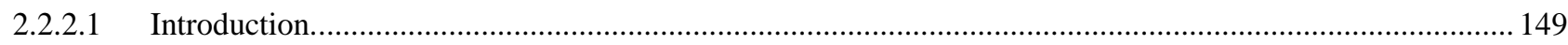

2.2.2.2 Socio-environmental benefits generated by the Barts and the London Hospitals........................................ 150

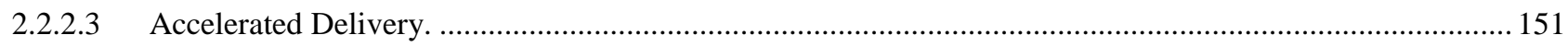

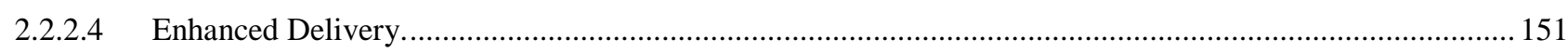

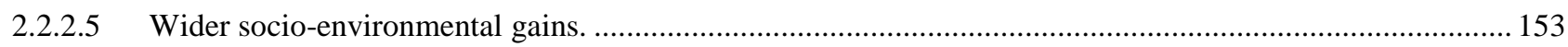

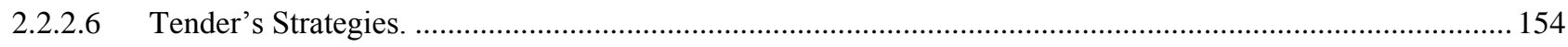

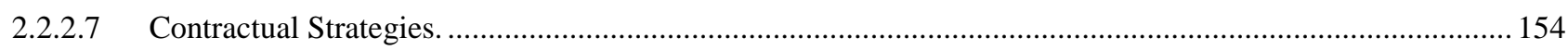

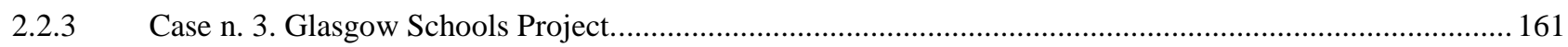

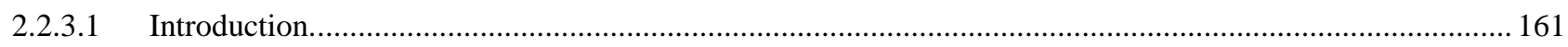

2.2.3.2 Socio-environmental benefits generated by the Glasgow Schools Project. ............................................... 162

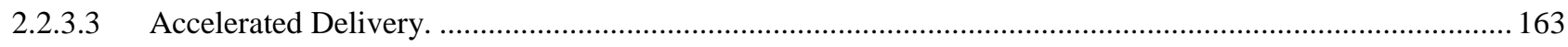

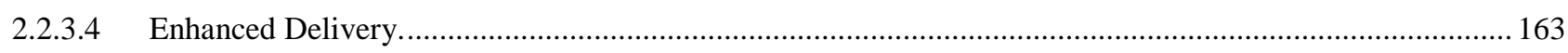

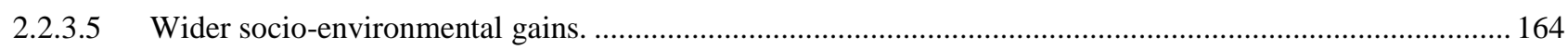

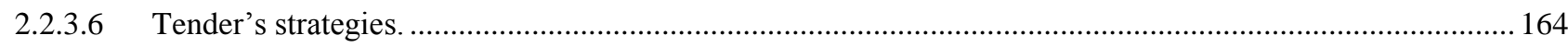

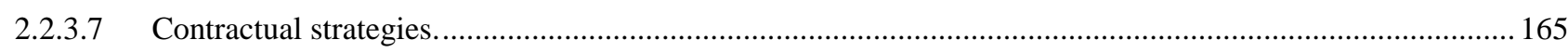

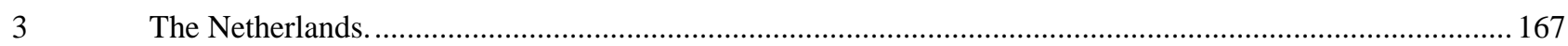

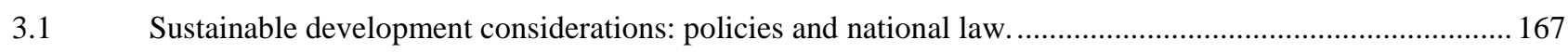

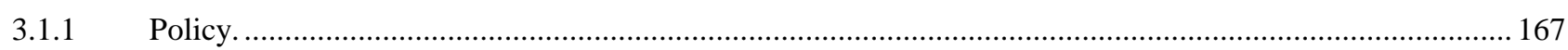

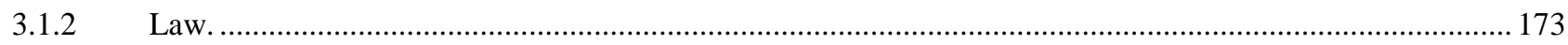

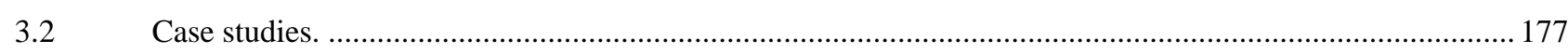

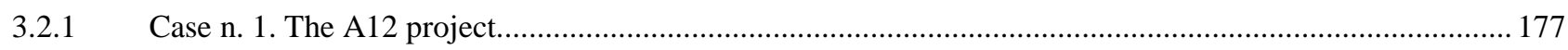

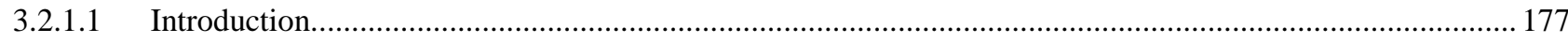

3.2.1.2 Socio-environmental benefits generated by the A12 project. ............................................................... 178

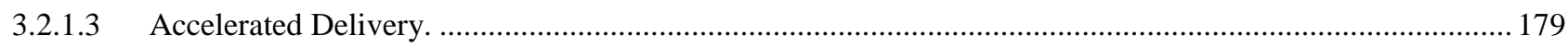

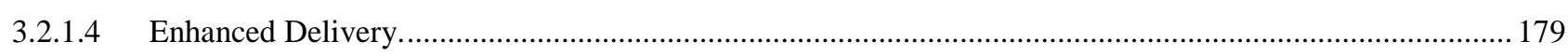

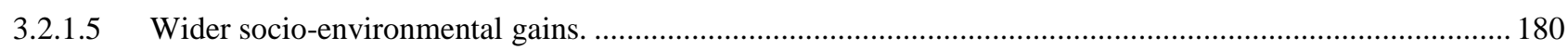

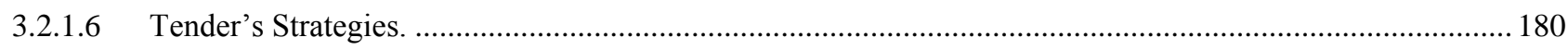

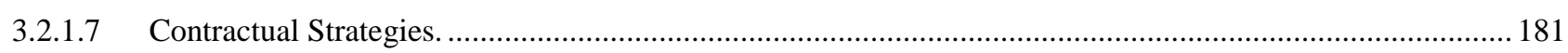

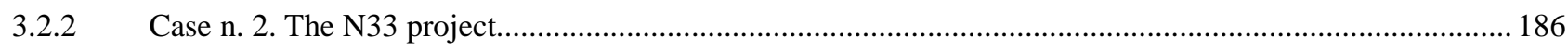

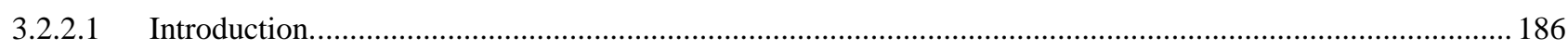

3.2.2.2 Socio-environmental benefits generated by the N33 project. …............................................................ 187

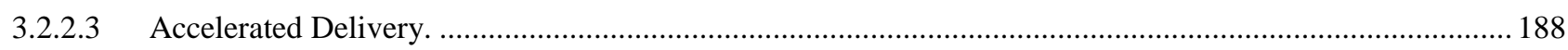

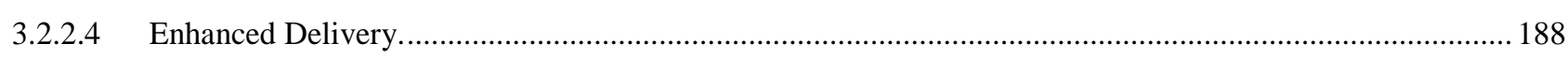

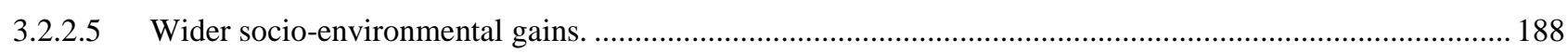

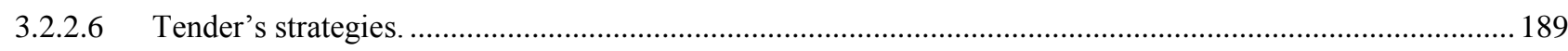

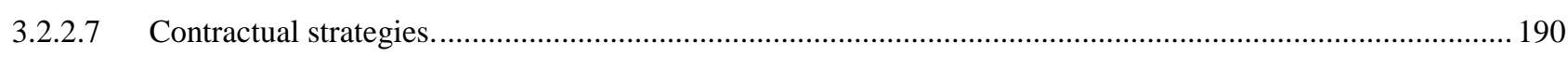

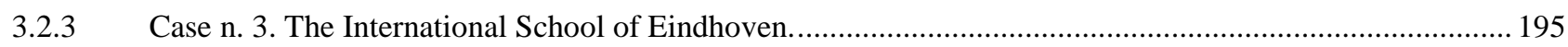

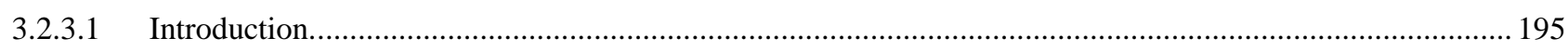

3.2.3.2 Socio-environmental benefits generated by the International School of Eindhoven project. ...................... 196

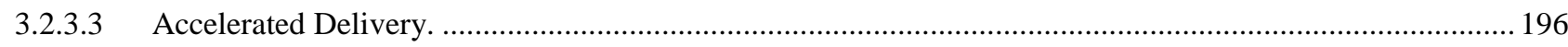

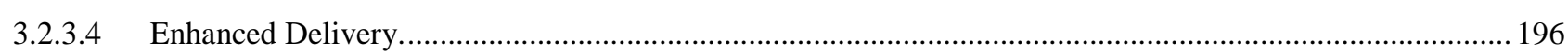




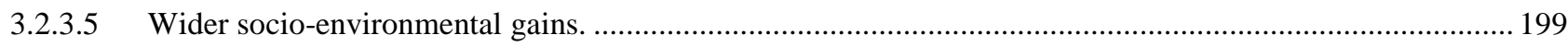

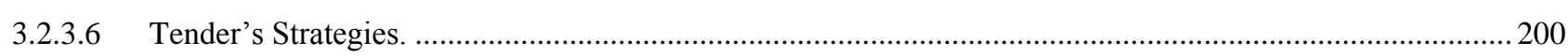

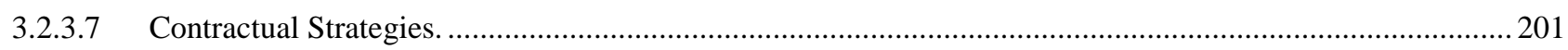

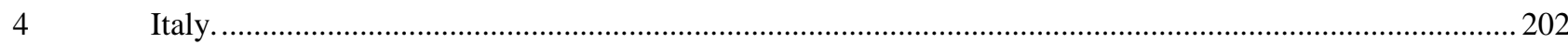

4.1 Sustainable development considerations: policies and national law......................................................202

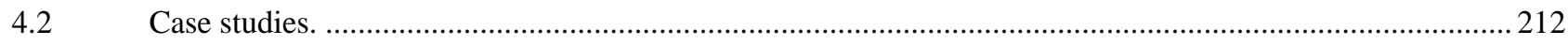

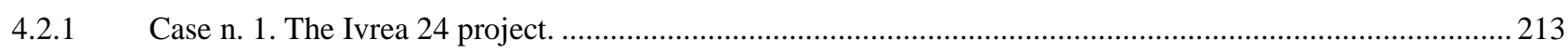

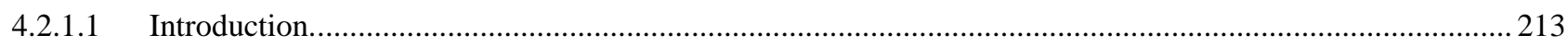

4.2.1.2 Socio-environmental benefits generated by the Ivrea 24 project. ....................................................215

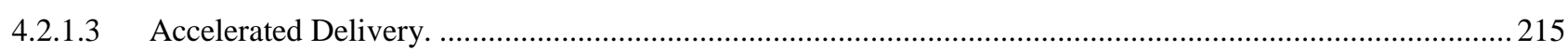

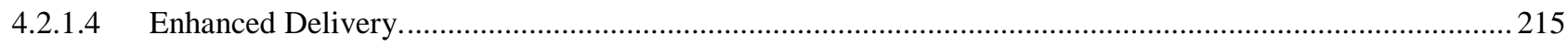

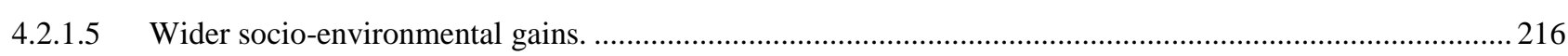

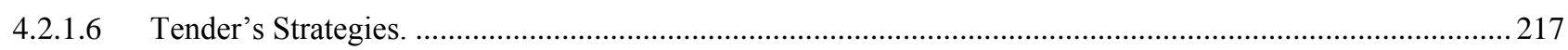

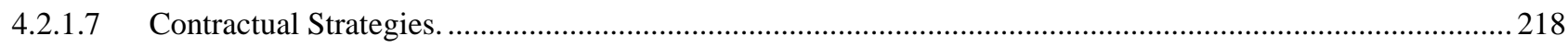

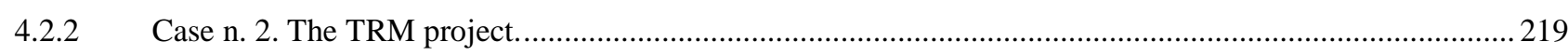

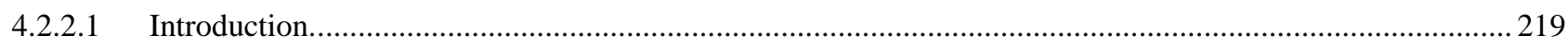

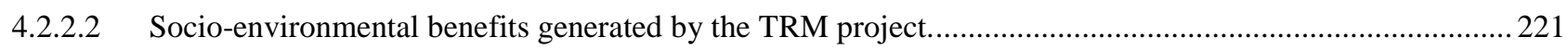

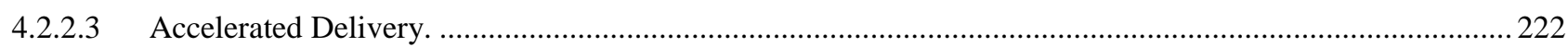

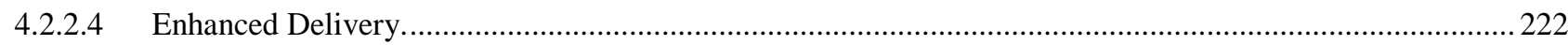

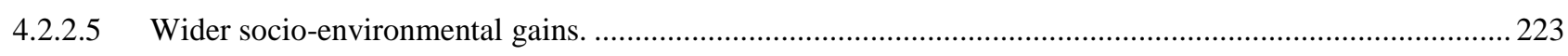

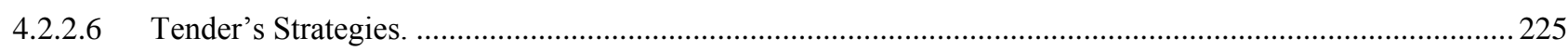

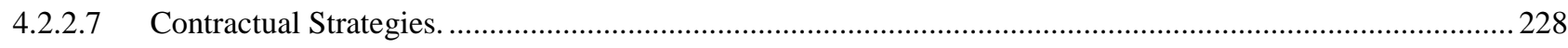

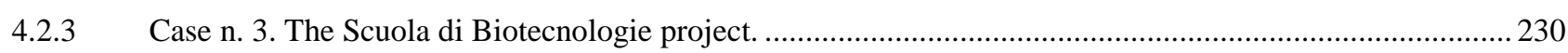

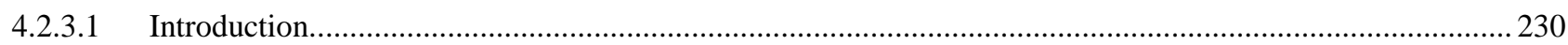

4.2.3.2 Socio-environmental benefits generated by the Scuola di Biotecnologie project. .......................................232

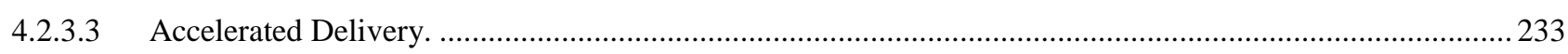

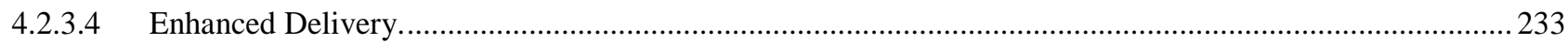

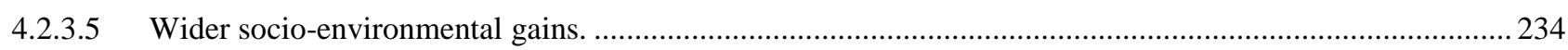

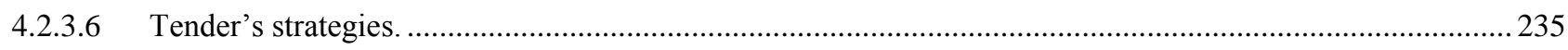

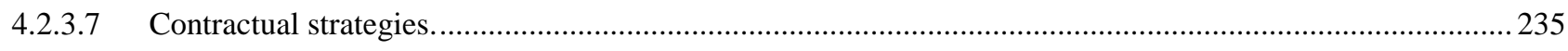

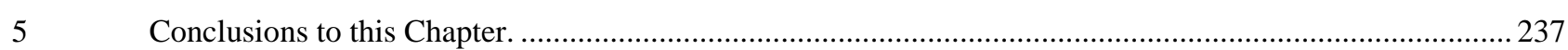

V CHAPTER - GENERAL CONCLUSIONS TO THIS STUDY .....................................................................................................................245

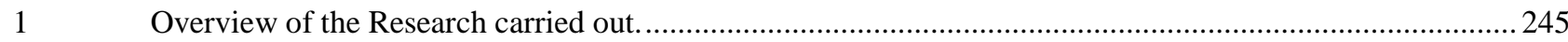

2 Acknowledgments and Achievements of this Study with respect to the Research Questions. .....................248

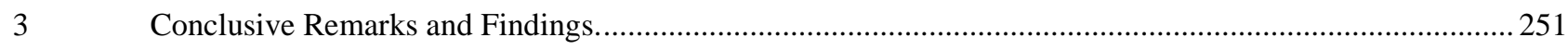

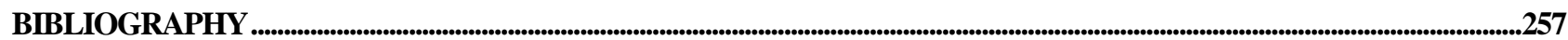

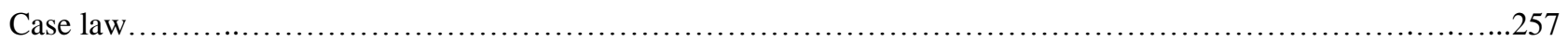

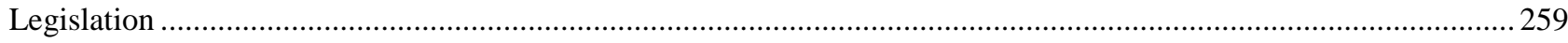

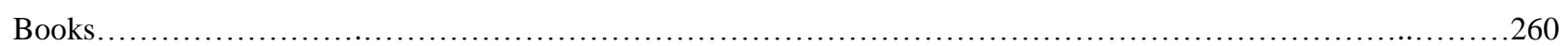

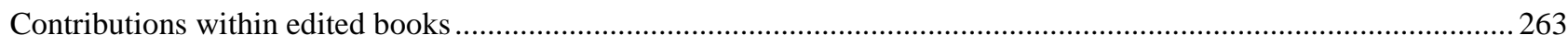

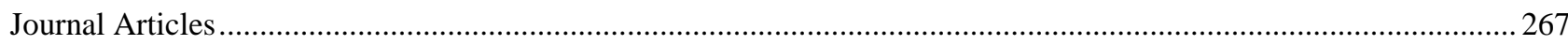

VIII 
Reports and other types of publications

EU soft law 


\section{CHAPTER - INTRODUCTION}

\section{Aim of the study and Research Questions.}

The widely accepted statement on the need for economic growth, innovation and sustainable development in the European Union (hereinafter EU) is increasingly driving Member States towards a smarter procurement of public services and infrastructure. ${ }^{1}$ Additionally, the evolution towards an innovation model - whereby innovation is the new knowledge for economic and socioenvironmental gains - is pushing Member States to endorse and resort to PPP arrangements and transfer private expertise to the public sector. Public-private collaborations, thus, represent a new strategically important tool to target EU productivity and sustainable development goals. ${ }^{2}$

Between the 1970s and the 1980s, various EU jurisdictions began to privatize public companies, driven by efficiency and political concerns. ${ }^{3}$ Public services, such as telecommunications, electricity and public health, came first. Then, governments began to be willing to extend the advantages of private sector's participation to areas perceived as difficult to privatize, such as transportation and schools. This evolution led to the development of PPPs: longterm contracts between public authorities and private businesses for the provision of public services and/or infrastructure. ${ }^{4}$

Before the rise of PPPs, States usually provided public infrastructure and/or services on their own. The construction of a project was contracted out to a private firm while the funding came from taxes or public debt. The private company after building the asset received the agreed payment, thereby performing the contract. At that point, a specific public sector department took care of the management and maintenance of the infrastructure.

Under traditional public procurement, splitting the building and operating phases entailed that the planning phase did not adequately incorporate future maintenance and operating costs. In addition, the public sector often preferred to invest in new projects rather than on routine maintenance. Disregard for maintenance led to the worsening of service quality until the contracting authority's decision to respond to local needs through the reconstruction of the infrastructure, albeit, at high costs. PPPs introduced a new approach to public provision: one private company finances

\footnotetext{
${ }^{1}$ For instance, see the Communication from the Commission to the European Parliament, the Council, the European Economic and Social Committee and the Committee of the Regions, Taking Stock of the Europe 2020 Strategy for Smart, Sustainable and Inclusive Growth, Brussels, 19.3.2014, COM (2014) $130 \mathrm{final} / 2$. On December 2014, the United Nations encouraged the engagement in public-private partnerships in order to catalyze global solidarity for sustainable development. United Nations General Assembly, The Road to Dignity by 2030: Ending Poverty, Transforming all Lives and Protecting the Planet - Synthesis Report of the Secretary General on the Post-2015 Sustainable Development Agenda, December 4, 2014, para 81, available at http://www.un.org/disabilities/documents/reports/SG_Synthesis_Report_Road_to_Dignity_by_2030.pdf.

${ }^{2}$ In this respect, an important challenge for the EU will be to develop a comprehensive ad hoc legal framework that promotes an effective use of PPPs.

${ }^{3}$ See, for instance, E Engel, R D Fischer, A Galetovic, The Economics of Public-Private Partnerships, A Basic Guide (Cambridge University Press, 2014), 1.

${ }^{4}$ See, among others, E R Yescombe, Public-Private Partnerships: Principles of Policy and Finance (Elsevier, 2007). G C Feroni, Il Partenariato Pubblico-Privato: Modelli e Strumenti (Giappichelli, 2011). F Mastragostino, La collaborazione pubblico-privato e l'ordinamento amministrativo: dinamiche e modelli di partenariato in base alle recenti riforme (Giappichelli, 2011). R Dipace, Partenariato Pubblico Privato e Contratti Atipici (Giuffrè, 2006).
} 
and builds a public infrastructure or delivers a public service. The private party is entrusted also with the operation and maintenance of the asset or service upon performance and availability standards throughout the contract life. Instead, the public sector, once defined the project's objectives in terms of public interest, quality of services and pricing policy, monitors the compliance by the private party with such objectives.

PPPs expanded rapidly over the past two decades. It is a trend that will likely increase, especially during the recovery of developed countries from the 2008 financial crisis, which led to general severe budgetary constraints.

Within this picture, this thesis challenges the understanding of public-private collaborations that does embrace, or better, that does not sufficiently take into consideration the potentialities of PPPs in the generation of also socio-environmental benefits. PPPs are, in fact, generally perceived as positive tools only from an economic and financial point of view. Instead, this thesis recognises and holds that PPPs also have the ability of promoting sustainable development goals through the generation of socio-environmental benefits. Thus, PPPs' structures have to include spaces for sustainable considerations.

In the ongoing process of boosting EU's economic growth and innovation, PPPs should be strategically used in order to endorse socio-environmental considerations along with Internal Market concerns. ${ }^{5}$ PPPs have, in fact, high potentialities in the generation of socio-environmental benefits. ${ }^{6}$ Thanks to their inherent features, they allow scope for smart and sustainable solutions. ${ }^{7}$ The following, non-exhaustive list, indicates the main reasons for this.

i. All phases of a certain project are awarded to one private contractor. In traditional procurements, each phase is, instead, normally contracted out to a different party. This allows the private party to plan ahead, covering all different aspects of a project, including its management and maintenance.

ii. The project's costs are pre-determined and normally borne by the private party. Usually, the public sector repays the sums invested through instalments only if the agreed outcomes are delivered. If the private party does not deliver the project as agreed upon, the public sector can withhold part of its payments. For the private sector, this represents a great incentive to deliver high quality assets on time. For the public sector, it is a solution that allows the setting of sustainable and/or innovative goals and a comprehensive view of future expenses (which is very useful in public financial planning).

iii. Through a smart allocation of tasks and risks, the public and private parties involved have the chance of doing what they are actually best at.

iv. Given the long duration of such cooperative schemes, the private party has the incentive to invest in new technologies, sustainable and innovative solutions (in order to reduce the project's total costs over the lifetime of the asset delivered).

\footnotetext{
${ }^{5}$ See the Green Paper on Public-Private Partnerships and Community law on Public Contracts and Concessions, COM (2004) 327 final.

${ }^{6}$ The scope for sustainability considerations in PPPs will be specifically investigated in Chapter III, paragraph 4.

${ }^{7}$ For detailed analyses on public-private schemes, see, among others, the Green Paper on the Modernisation of EU Public Procurement Policy: European Commission, 'Towards a more efficient European Procurement Market', Brussels, 27.1.2011, COM(2011) 15 final. C H Bovis, 'The Notion of Public Concession as a Component of Public Private Partnerships' [2007] EPPPL 12. K Christian, W Julia, 'The Relevance of EC State Aid Control for PPP Infrastructure Funding' [2007] EPPPL, 5, 11.
} 
Thus, the public sector should choose and structure PPPs in the light of their ability to support and promote sustainable solutions. Public authorities are used to undertake projects only under the assumption that a specific investment is economically justified. In order to decide whether to deliver a public service or infrastructure through a classic procurement option or a PPP scheme, costs comparisons at specific standards are normally carried out. Typically, cost-minimisation approaches implicitly consider the socio-environmental benefits related to different delivery models as ultimately the same. ${ }^{8}$ However, this is not always the case. In fact, as briefly seen above, the incentives inherent in the particular characteristics of PPP cooperative models are capable of delivering potentially high levels of socio-environmental benefits. ${ }^{9}$ This study builds from the assumption that the overall incentives specific to PPP schemes - if actually endorsed in the direction of sustainable development promotion - have the ability of creating actual spaces for sustainability concerns, therefore, fostering sustainable development through the generation of socioenvironmental benefits. As mentioned, PPPs have the potential of allowing the private sector to apply innovation at all levels of a project delivery. They have attached a particular set of incentives, which is supported by a composite contract structure where especially the agreed payment mechanism, and related financial arrangements are organised in a way that maximizes the chances for the public service or infrastructure to be delivered in a sustainable way. ${ }^{10}$ Therefore, moving from this consideration, the actual potentialities of PPPs in the delivery of socio-environmental benefits will be investigated. The latter will be described as accelerated deliveries, the delivery of services and/or infrastructure with high quality standards and wider beneficial socio-environmental impacts. ${ }^{11}$

This thesis seeks to provide a scientific contribution to the field of PPPs by exploring a specific aspect of such schemes, which is generally overlooked by legal and economic scholars and by public and private actors: their ability to generate also socio-environmental benefits and, thus, their capability to promote sustainable development objectives within the EU. Therefore, this study explores a different understanding of PPPs whereby social and environmental concerns are fully embraced and where sustainable development goals are actually promoted.

To this end, this thesis will study which are the spaces for sustainable development considerations within PPP structures according to EU public contracts and concessions law as well as according to the relevant domestic regimes of the Member States studied. Moreover, this thesis will identify - along with the potential socio-environmental benefits achievable through PPPs - the concrete tender and contractual strategies that may allow the integration of sustainability considerations within PPPs and, thus, the generation of socio-environmental benefits.

Therefore, this thesis seeks to address the following central research questions: can PPPs be considered as public services and infrastructure delivery models actually capable of promoting

\footnotetext{
${ }^{8}$ Cost-minimisation approaches may be defined as financial strategies that aim at identifying the most cost-effective way of delivering a good or service with respect to the required level of quality.

${ }^{9}$ The Non-Financial Benefits of PPPs, A Review of Concepts and Methodology, European PPP Expertise Centre, European Investment Bank, June 2011, 5, available at http://www.eib.org/epec/resources/epec-non-financial-benefitsof-ppps-public.pdf.

10 The legal regimes of these arrangements are diverse and display different models of both financing and asset ownership. See, for instance, M Burnett, 'Beyond the New Public Procurement Directive - the Future for Public Private Partnerships' [2005] Eipascope, 21, 25.

${ }^{11}$ On PPPs' socio-environmental benefits please refer below to Chapter III, paragraph 5. In this respect, see also, The Non-Financial Benefits of PPPs, A Review of Concepts and Methodology, European PPP Expertise Centre, European Investment Bank, June 2011, available at http://www.eib.org/epec/resources/epec-non-financial-benefits-of-pppspublic.pdf..
} 
sustainable development goals through the generation of socio-environmental benefits? Which are the spaces for sustainable development concerns that can be located within PPPs' structures according to EU public contracts and concessions law? Which are the spaces for sustainable development considerations that can be located within PPP schemes according to the public contracts and concessions laws of the Members States studied in this thesis? Through which means (i.e. tender and contractual strategies) public and private actors may actually integrate sustainability concerns within PPPs' structures and, therefore, deliver also socio-environmental benefits? In other words, which is the scope, from a legal point of view, for sustainable development within PPPs? Which are the concrete strategies that may allow public and private actors to implement socioenvironmental considerations within PPP structures and, thus, foster sustainable development throughout the EU?

\section{Definitions and Summary of the Literature Review.}

There is no unique or widely accepted definition of PPPs. There is a large variety of definitions used by academics and practitioners, especially in the fields of economics and law. All around the world 'the public-private association has become a perniciously broad category'. ${ }^{12}$

This thesis will adopt and use as a reference point the definition of PPPs given by the EU Commission in the 2004 Green Paper on PPPs. ${ }^{13}$ The term PPP will refer to any form 'of cooperation between public authorities and the world of businesses which aim to ensure the funding, construction, renovation, management or maintenance of infrastructure or the provision of a service. ${ }^{14}$ Therefore, the term PPP will refer to any legal scheme characterised by the following elements:

i. the long duration of the cooperation arrangement, where the public and the private sectors work together on various aspects of the project;

ii. the funding method, which mainly comes from the private party and may be completed by public funds;

iii. the participation of the economic operator at the different phases of the project;

iv. the definition of the project's objectives in terms of public interest, quality of services and pricing policy by the public party, which then monitors the compliance with the said objectives by the private operator;

v. the distribution of risks between the public and the private sectors according to their respective abilities to assess, control and deal with them. ${ }^{15}$

\footnotetext{
${ }^{12}$ See, J D Donaghue, R Zeckhauser, Collaborative Governance: Private Roles for Public Goals in Turbulent Times, (Princeton University Press, 2011) 259.

${ }^{13}$ Green Paper on Public-Private Partnerships and Community Law on Public Contracts and Concessions, Brussels, 30.4.2004 COM (2004) 327 final.

${ }^{14}$ This is the definition given - in very general terms - by the EU Commission in the Green Paper on Public-Private Partnerships and Community Law on Public Contracts and Concessions, Brussels, 30.4.2004 COM (2004) 327 final, 3.

${ }^{15}$ According to the Commission's view, these elements characterise PPP arrangements. See the Green Paper on PublicPrivate Partnerships and Community Law on Public Contracts and Concessions, Brussels, 30.4.2004 COM (2004) 327 final, 3 .
} 
Given the above, the Table below shows whether the legal schemes indicated in the first column fall or not within the PPP notion adopted by this thesis.

\begin{tabular}{|c|c|c|c|c|c|c|c|}
\hline & $\begin{array}{c}\text { Cooperation } \\
\text { aiming at } \\
\text { ensuring the } \\
\text { funding, } \\
\text { construction, } \\
\text { renovation, } \\
\text { management } \\
\text { or } \\
\text { maintenance } \\
\text { of } \\
\text { infrastructure } \\
\text { or the } \\
\text { provision of a } \\
\text { service }\end{array}$ & $\begin{array}{c}\text { Long } \\
\text { duration of } \\
\text { the } \\
\text { cooperation } \\
\text { arrangement } \\
\text { (the public } \\
\text { and private } \\
\text { sectors } \\
\text { collaborate } \\
\text { on various } \\
\text { aspects of the } \\
\text { project) }\end{array}$ & $\begin{array}{l}\text { Funding } \\
\text { method } \\
\text { (mainly } \\
\text { from the } \\
\text { private } \\
\text { party and } \\
\text { may be } \\
\text { completed } \\
\text { by public } \\
\text { funds) }\end{array}$ & $\begin{array}{c}\text { Participation } \\
\text { of the } \\
\text { economic } \\
\text { operator at } \\
\text { the different } \\
\text { phases of the } \\
\text { project }\end{array}$ & $\begin{array}{c}\text { Definition } \\
\text { of the } \\
\text { objectives } \\
\text { in terms of } \\
\text { public } \\
\text { interest, } \\
\text { quality of } \\
\text { services } \\
\text { and pricing } \\
\text { policy by } \\
\text { the public } \\
\text { party } \\
\text { (compliance } \\
\text { monitoring) }\end{array}$ & $\begin{array}{c}\text { Distribution } \\
\text { of risks } \\
\text { between the } \\
\text { public and } \\
\text { the private } \\
\text { sectors } \\
\text { (according } \\
\text { to their } \\
\text { respective } \\
\text { abilities to } \\
\text { assess, } \\
\text { control and } \\
\text { deal with } \\
\text { them) }\end{array}$ & $\begin{array}{l}\rightarrow \\
\text { PPP } \\
\text { or } \\
\text { NO } \\
\text { PPP }\end{array}$ \\
\hline $\begin{array}{l}\text { Service } \\
\text { contracts }\end{array}$ & $\begin{array}{l}\text { NO } \\
\text { The selected } \\
\text { private party } \\
\text { performs the } \\
\text { contract in } \\
\text { accordance with } \\
\text { the standards of } \\
\text { the service set by } \\
\text { the public party }\end{array}$ & $\begin{array}{c}\text { NO } \\
\text { Service } \\
\text { contracts are } \\
\text { short term } \\
\text { agreements } \\
\text { (<5 years })\end{array}$ & $\begin{array}{l}\text { NO } \\
\text { The public } \\
\text { partner is } \\
\text { responsible } \\
\text { for every } \\
\text { capital } \\
\text { investment }\end{array}$ & $\begin{array}{l}\text { NO } \\
\text { The private } \\
\text { partner only } \\
\text { delivers a } \\
\text { defined part of } \\
\text { the service }\end{array}$ & YES & $\begin{array}{l}\text { NO } \\
\text { The public } \\
\text { partner bears } \\
\text { most of the } \\
\text { risks }\end{array}$ & $\begin{array}{l}\overrightarrow{ } \\
\mathrm{NO} \\
\mathrm{PPP}\end{array}$ \\
\hline $\begin{array}{l}\text { Management } \\
\text { contracts }\end{array}$ & $\begin{array}{c}\text { NO } \\
\text { The selected } \\
\text { private party } \\
\text { delivers and } \\
\text { manages the } \\
\text { service in } \\
\text { accordance with } \\
\text { the standards of } \\
\text { the service set out } \\
\text { by the public } \\
\text { party }\end{array}$ & $\begin{array}{c}\text { NO } \\
\text { Management } \\
\text { contracts are } \\
\text { medium term } \\
\text { agreements } \\
\text { (3 to } 5 \text { years) }\end{array}$ & $\begin{array}{l}\text { NO } \\
\text { The private } \\
\text { party } \\
\text { provides the } \\
\text { working } \\
\text { capital (i.e. } \\
\text { for daily } \\
\text { operations). } \\
\text { The public } \\
\text { partner } \\
\text { finances } \\
\text { capital } \\
\text { investments }\end{array}$ & $\begin{array}{l}\text { NO } \\
\text { The private } \\
\text { partner only } \\
\text { delivers a } \\
\text { defined part of } \\
\text { the service }\end{array}$ & YES & YES & $\begin{array}{c}\rightarrow \\
\text { NO } \\
\text { PPP }\end{array}$ \\
\hline
\end{tabular}




\begin{tabular}{|c|c|c|c|c|c|c|c|}
\hline $\begin{array}{l}\text { Concession } \\
\text { contracts }\end{array}$ & YES & $\begin{array}{l}\text { YES } \\
\text { Concession } \\
\text { contracts are } \\
\text { long term } \\
\text { contracts } \\
\text { (25 to } 30 \\
\text { years) }\end{array}$ & $\begin{array}{c}\text { YES } \\
\text { The private } \\
\text { party is } \\
\text { responsible for } \\
\text { capital } \\
\text { investments } \\
\text { (potential } \\
\text { public party's } \\
\text { support for } \\
\text { capital } \\
\text { investment } \\
\text { costs) }\end{array}$ & YES & YES & YES & $\begin{array}{l}\overrightarrow{\mathrm{PPP}} \\
\end{array}$ \\
\hline $\begin{array}{c}\text { PFI } \\
\text { contracts } \\
\text { (Private } \\
\text { Finance } \\
\text { Initiative) }\end{array}$ & YES & $\begin{array}{c}\text { YES } \\
\text { PFIs are long } \\
\text { term contracts } \\
\text { (25 to } 30 \\
\text { years) }\end{array}$ & $\begin{array}{c}\text { YES } \\
\text { The private } \\
\text { party is } \\
\text { responsible for } \\
\text { capital } \\
\text { investments }\end{array}$ & YES & YES & YES & $\begin{array}{l}\overrightarrow{\mathrm{PPP}} \\
\end{array}$ \\
\hline $\begin{array}{c}\text { BOT } \\
\text { contracts } \\
\text { (Build- } \\
\text { Operate } \\
\text { Transfer) }\end{array}$ & YES & $\begin{array}{l}\text { YES } \\
\text { BOT contracts } \\
\text { may be long } \\
\text { term contracts } \\
\text { (the duration } \\
\text { of the contract } \\
\text { depends on the } \\
\text { time needed to } \\
\text { the private } \\
\text { party to } \\
\text { recover the } \\
\text { investments } \\
\text { made from } \\
\text { end-users) }\end{array}$ & $\begin{array}{c}\text { YES } \\
\text { The private } \\
\text { party finances } \\
\text { the } \\
\text { construction } \\
\text { (the public } \\
\text { partner may } \\
\text { commit to a } \\
\text { certain level of } \\
\text { purchasing in } \\
\text { order to } \\
\text { guarantee the } \\
\text { private } \\
\text { partner's } \\
\text { operating } \\
\text { costs) }\end{array}$ & YES & YES & YES & $\begin{array}{l}\rightarrow \\
\mathrm{PPP}\end{array}$ \\
\hline $\begin{array}{l}\text { DBFM } \\
\text { contracts } \\
\text { (design, } \\
\text { build, } \\
\text { finance and } \\
\text { maintain } \\
\text { contracts) }\end{array}$ & YES & $\begin{array}{c}\text { YES } \\
\text { DBFM } \\
\text { contracts are } \\
\text { long term } \\
\text { contracts } \\
\text { (25 to } 30 \\
\text { years) }\end{array}$ & $\begin{array}{c}\text { YES } \\
\text { The private } \\
\text { party is } \\
\text { responsible for } \\
\text { the funding of } \\
\text { the project } \\
\text { (the public } \\
\text { party pays to } \\
\text { the private } \\
\text { partner fees } \\
\text { upon } \\
\text { performance } \\
\text { and } \\
\text { availability } \\
\text { standards) }\end{array}$ & YES & YES & YES & $\begin{array}{l}\overrightarrow{\mathrm{PPP}} \\
\mathrm{P}\end{array}$ \\
\hline
\end{tabular}

Table 1 Procurement schemes falling or not within the PPP notion. 
Many different definitions and types also characterize the notions of public infrastructure and services ${ }^{16}$. For the purpose of this thesis, the terms public infrastructure and services will be used to refer to any long-lasting investment program for the provision of public infrastructure or services such as a highway, airport, seaport, school, housing scheme or health care institution. An infrastructure or service can be defined as public if it aims at satisfying essential needs of the society and it is subject to a particular regime in light of the importance of the interests pursued. Since there is no agreement on a unique and all-encompassing definition of public infrastructure and services, the latter are generally identified and defined as 'public' whenever certain indicators reveal their public nature. These indicators, for the purpose of this thesis, will be: (i) the direct satisfaction by the infrastructure or service considered of needs of general interest (which can be defined as the 'functional element'); and (ii) the fact that the infrastructure or service is subject to a particular regime because of the social relevance of the interests pursued (which may be defined as the 'organizational element'). Therefore, regardless of the specific way through which an infrastructure or service is delivered, its public nature derives from the particular regime (i.e. public law regime) to which it is subject to and from the aim pursued (i.e. need of general interest).

Moreover, the terms efficiency, effectiveness, cost effectiveness and economic efficiency, when used in this thesis, will refer to the following concepts.

The term efficiency will indicate the ability of a specific mean or process to produce a certain outcome with a minimum waste of resources, such as physical materials, energy or time, while successfully achieving the desired output. Efficiency is normally a measurable concept that can be determined by the ratio of useful output to total input. Effectiveness, instead, may be expressed quantitatively and will refer to the degree to which objectives are achieved by a mean or a process and to the extent to which targeted problems are tackled. Therefore, whereas efficiency will mean performing or functioning in the best possible manner with the least waste of time and effort, effectiveness will consist in the ability to achieve the desired result or in the suitability of a given process of accomplishing a certain purpose.

Furthermore, the term cost effectiveness will refer to the economic approach that allows to depict the extent to which a process or mean can be considered to represent VfM. ${ }^{17}$ Costeffectiveness analysis may be defined as an economic evaluation technique whereby the choice of a certain mean depends on the nature of the benefits attached to it. ${ }^{18}$ In cost-effectiveness analyses, consequences of different processes are measured using a single outcome. Alternative delivery means are then compared in terms of costs per each result achieved. As with all economic evaluation techniques, the aim of cost effectiveness analyses is to maximize the level of benefits with respect to the available resources.

\footnotetext{
${ }^{16}$ G Torrisi, "Public infrastructure: definition, classification and measurement issue" [2009] Munich Personal RePEc Archive, 6; F Nicotra, "Nozione di servizio pubblico nel diritto interno e comunitario" [2015] available at https://www.diritto.it/la-nozione-di-servizio-pubblico-nel-diritto-interno-e-comunitario/.

${ }^{17}$ Thus, in the field of public procurement, if the same quantity and quality of a service or infrastructure is delivered at a lower overall cost.

${ }^{18}$ On cost effectiveness see also C Phillips, What is cost effectiveness?, Health Economics, 2009, available at http://www.bandolier.org.uk/painres/download/whatis/Cost-effect.pdf; National Institute for Health and Clinical Excellence, Guide to the methods of technology appraisal, 2013, available at https://www.nice.org.uk/process/pmg9/chapter/foreword; C McCabe, "What is cost-utility analysis?" [2009], Hayward Medical Communications, available at http://www.whatisseries.co.uk/what-is-cost-utility-analysis/. 
The term economic efficiency will, instead, refer to the general concept of optimization of resources in order to best serve and reach the desired result while minimizing waste and inefficiency. It is a notion that implies that benefits outweigh losses. There is no specific threshold that determines the economic efficiency of a given process, however, indications in this sense may include, for instance, the fact that goods are produced at the lowest possible cost and labor, being performed with the greatest possible output.

Many definitions then characterise the notion of sustainable development. ${ }^{19}$ It is a broad and abstract concept, which brings together various meanings that are often understood differently among individuals, professionals, interest groups, State agencies, political leaders and NGOs. In this thesis, the term sustainable development will refer to a particular vision of growth where social, economic and environmental considerations are integrated with one another as inseparable and interdependent components of human progress. The concept of sustainable development embraced by this thesis will be the following: a development that entails a synergy between the economic, environmental and social dimensions of human life in order to move towards a new and integrated approach of human progress.

Moreover, the term socio-environmental benefit will encompass any and all social and environmental gain enjoyed by end-users, wider society and surrounding territory arising out the operation of a public infrastructure and/or service. ${ }^{20}$ Socio-environmental benefits differ from financial ones essentially because they - generally - do not represent cash inflows and/or outflows. They range from social and welfare gains to environmental positive achievements and improvements. Environmental benefits may arise out climate change concerns, the promotion of energy savings, of alternative energy sources or of resource efficiencies. Social benefits may, instead, arise out social and territorial cohesion: such as better connectivity between cities, creation of green areas, promotion of health and safety of communities, social integration and inclusion, social integration of disadvantaged people or persons of vulnerable groups, design for all end-users, accessibility for persons with disabilities, strong community involvement, improvement of local facilities, promotion of cultural heritage, promotion of social and cultural community activities, and improved or high level of education. ${ }^{21}$

With regard to the literature reviewed to draft this thesis, a great variety of pieces coming from different research areas - scientific and non-scientific - was examined. This was because the concept of PPP covers diverse fields of study. Therefore, legal, economic, managerial and sociological academic works, reports, guidelines and studies prepared by practitioners and/or nongovernmental bodies were investigated. The literature reviewed has been critically scrutinized and valued according to its source and scientific contribution in light of the scope of this research.

\footnotetext{
${ }^{19}$ On the concept of sustainable development, please, refer to Chapter III, paragraph 1.

${ }^{20}$ See below, Chapter III, paragraph 5.

${ }_{21}$ Moreover, social benefits may arise out the promotion of tax compliance, the fight against unfair commercial practices and employment-related considerations. These include matters such as promotion of high-employment, employment of disadvantaged categories, gender equality and equal opportunities, non-discrimination, exclusion of child labour, minimum labour conditions, compliance with ILO and human rights conventions, workplace safety and health, and traineeships. Moreover, social benefits may also arise out certain social and labour conditions within the supply-chain: such as fair-trade conditions of the goods, works or services purchased (e.g. purchase of products from small-scale producers in developing countries at favourable trading standards, ethical production methods) measures aiming at the protection of the health of the staff involved in the performance of the contract, fair wages of persons involved in the procurement process.
} 
Legal literature on PPPs is limited because of the absence of a specific legal framework regulating them. ${ }^{22}$ At a European level, the Treaty principles and the EU public contracts and concessions regime represent the PPP legal reference point. While the Treaty principles apply to any PPP arrangement, EU public contracts and concessions rules apply differently according to the specific legal scheme used to carry out the public-private cooperation, e.g. concession contract, project financing or joint venture. At a national level, there is generally no regulation of the PPP category as a whole. ${ }^{23}$ Usually, only certain legal types of PPPs are specifically regulated. ${ }^{24}$ Additionally, national rules may vary from jurisdiction to jurisdiction.

Furthermore, legal literature on PPPs appears to be weak on the study of PPPs' capability to integrate socio-environmental considerations and, thus, on their ability to promote sustainable development goals. Whereas, especially sociological and managerial works and studies prepared by practitioners and/or non-governmental bodies provide significant in-puts on the issue. ${ }^{25}$ Hence, in order to fill in this gap, this thesis will carry out a new and different study of PPPs, which investigates their ability to integrate socio-environmental concerns within their structures in order to foster sustainable development. While most legal and economic scholars' efforts are concentrated on PPPs' economic benefits and drawbacks, ${ }^{26}$ less, or better, very little attention, is put on the study of PPPs as effective delivery means of sustainable public services and/or infrastructure. ${ }^{27}$ For this reason, the aim of this thesis will be to open a new discussion on PPPs, which explores their actual ability to generate socio-environmental benefits and, hence, to promote sustainable development goals.

Scientific theoretical approaches to PPPs generally focus exclusively on their economic feasibility and start from the premise that they are economically beneficial means, without, however, taking into account their capability to deliver also socio-environmental sustainability. ${ }^{28}$ For instance, PPPs are generally praised because they enable off-budget funding of infrastructure and/or service projects and attract foreign investments by taking advantage of the private sector's expertise and skills. The large majority of the existing scientific literature on PPPs focuses on the related financial and/or non-financial risks and on the protection of private sector's investments. ${ }^{29}$ The broader social and environmental context and gains are normally overlooked. Few works deal

\footnotetext{
${ }^{22}$ See below, Chapter II, paragraph 4.

${ }^{23}$ Except for Italy, see below Chapter IV.

${ }^{24}$ For instance, concession contracts.

${ }^{25}$ T De Lemos, L Almeida, M Betts, D Eaton, 'An Examination on the Sustainable Competitive Advantage of Private Finance Initiative Projects' [2003] Construction Innovation, Information, Process, Management, 249, 259. N Wang, R Ding, M Radosavljevic, H Sun, 'Practicing Sustainability in PFI Project Management' [2011] Technology Management Conference, IEEE International, 717, 722.

${ }^{26}$ Among others, see, B Li, A Akintoye, P J Edwards, C Hardcastle, 'Perceptions of Positive and Negative Factors Influencing the Attractiveness of PPP/PFI Procurement for Construction Projects in the UK' [2005] Engineering, Construction and Architectural Management, 125, 148. R Osei-Kyei, A P C Chan, 'Review of Studies on the Critical Success Factors for Public-Private Partnership (PPP) Projects from 1990 to 2013' [2015] International Journal of Project Management, 1335, 1346. H Smyth, A Edkins, 'Relationship Management in the Management of PFI/PPP Projects in the UK' [2007] International Journal of Project Management, 232, 240. Broadbent, R Laughlin, 'The Role of PFI in the UK Government's Modernization Agenda' [2005] Financial Accountability and Management, $721,746$.

${ }^{27}$ See, inter alia, R Garwood, 'Sustainability Lessons from Private Finance and Similar Private Initiatives' [2002] Information Paper, BRE. L Zhou, R Keivani, E Kurul, 'Sustainability Performance Measurement Framework for PFI projects in the UK' [2013] Journal of Financial Management of Property and Construction, 232, 250. J Hill, J Collins, 'PFI: Meeting the Sustainability Challenge' [2004] Green Alliance, London.

${ }^{28} \mathrm{~J}$ Sussex, The Economics of the Private Finance Initiative in the NHS, (Office of Health Care Economics, 2001).

${ }^{29}$ See, Li Bing, A Akintoye, P J Edwards, C Hardcastle, 'The Allocation of Risk in PPP/PFI Construction Projects in the UK' [2005] International Journal of Project Management, 25, 35. J Froud, 'The Private Finance Initiative Risk, Uncertainty and the State' [2003] Accounting, Organizations and Society, 567, 89.
} 
with the potential environmental and social sustainability of PPP schemes in the delivery of infrastructure and/or service projects. ${ }^{30}$

The most comprehensive study on this issue concludes that traditional PPP arrangements do not sufficiently address environmental and social considerations. ${ }^{31}$ It further recommends how to improve PPPs' sustainability at a legislative and institutional level and during the various phases of a PPP scheme. Other authors highlight inconsistencies in the way PPP's stakeholders address sustainability issues in PPP projects. ${ }^{32}$ Another recent work concludes that PPP arrangements have failed to embrace an inclusive approach. ${ }^{33}$

Therefore, a review of the actual understating of PPPs had to be carried out in order to put society and the environment as major stakeholders in their implementation. In this respect, industrial organization and policy literature indicate that public-private cooperation, where the public and private sectors work together for the delivery of public infrastructure and/or services, generate great outcomes in terms of socio-environmental quality. ${ }^{34}$ Moreover, they argue that complementarities between collaborating partners deliver more effective results. ${ }^{35}$

Furthermore, hardly any case study showing the tender and contractual strategies that allow PPP projects to generate socio-environmental benefits were found. As said, the economic and financial feasibility of PPPs is normally the only lens through which these legal schemes are addressed.

Hence, the aim of this thesis will be to change the perspective in the study of PPPs and to fill in the gap related to the consideration of socio-environmental concerns in their design and implementation. This, by investigating the actual ability of PPPs to embed socio-environmental considerations in their structure and, thus, to promote sustainable development goals.

\section{Methodology and Structure.}

In order to discuss the actual capability of PPPs to generate socio-environmental benefits and, thus, their ability to promote sustainable development throughout the EU, a multi-disciplinary and heuristic approach will be adopted. The chosen methodology will combine real-world evidence with the existing literature on PPPs, including policy, social, environmental legal and economic perspectives. The study will, in fact, be an interplay between academic literature and PPPs' practical experiences. This thesis will use a deductive top-down methodology to investigate the

\footnotetext{
${ }^{30}$ For instance, see, Public-Private Partnerships and Sustainable Principles Guiding Legislation and Current Practice, B Ryan, Dublin Institute of Technology, 2004, available at http://arrow.dit.ie/cgi/viewcontent.cgi?article=1007\&context=futuresacrep. S Ng, J M Wong, K Wong, A Public Private People Partnerships (P4) Process Framework for Infrastructure Development in Hong Kong, Department of Civil Engineering, the University of Hong Kong, available at

http://isiarticles.com/bundles/Article/pre/pdf/3618.pdf. P Rwelamila, P Fewings, C Henjewele, Addressing the Missing Link in PPP Projects: What Constitutes the Public?' [2015] J. Manage. Eng., 56, 75.

${ }^{31}$ Harnessing the Power of Public-Private Partnerships: the Role of Hybrid Financing Strategies in Sustainable Development, International Institute for Sustainable Development, Colverson, Perera, available at http://www.iisd.org/pdf/2012/harnessing_ppp.pdf.

${ }^{32}$ Public-Private Partnerships and Sustainable Principles Guiding Legislation and Current Practice, B Ryan, Dublin Institute of Technology, op. cit.

${ }^{33}$ P Rwelamila, P Fewings, C Henjewele, 'Addressing the Missing Link in PPP Projects: What Constitutes the Public?' op. cit..

${ }^{34}$ See, among others, R De Bondt, 'Spillovers and Innovative Activities' [1997] International Journal of Industrial Organization, 1, 28.

${ }^{35}$ Ibid.. 
ability of PPPs to embed socio-environmental considerations within their structure and, thus, to promote sustainable development throughout Europe. A normative analysis will serve to delve into such discussion.

The study of the PPP phenomenon and the review of the legal framework applicable to it will represent the necessary starting point, without being the objective, of this thesis. As mentioned, PPPs cannot rely on an ad hoc regulation specifically dedicated to them, neither at EU nor at an International level. Therefore, Chapter II will serve the purpose of identifying the International and EU legal regime governing PPPs. At the same time, it will highlight the set of rules that will have to be analysed in order to explore the actual spaces for sustainable development considerations within these kind of complex public contracts. PPPs' current theoretical understanding focused on their acknowledgment foremost as economically beneficial means will be, furthermore, challenged and critically examined in the light of the assumption according to which also socio-environmental goals can be effectively promoted by PPPs through an inclusive approach. To this end, Chapters III and IV will investigate the actual spaces for sustainable development considerations within PPPs according to EU and considered national public contracts and concessions laws. Finally, Chapter IV will carry out an empirical study of representative PPP projects in the Member States studied, which will identify, along with the specific socio-environmental benefits delivered, the tender and contractual strategies, inherent in the particular structure of the PPP projects studied, which allowed the integration of sustainability concerns within their structure and, thus, the generation of socioenvironmental benefits. The case studies will serve as practical assessment of the actual ability of PPPs to deliver socio-environmental benefits and, thus, to promote sustainable development. The specific strategies - used in the PPPs studied - through which sustainable development goals were promoted will be presented in Chapter IV. These cannot per se be generalised as they pertain and are tailored to the specific characteristics of the projects studied. However, a comparative analysis of such strategies - disengaged as much as possible from the specific context of the projects in which they were used - will allow the identification of general key tender and contractual strategies. The latter will aim at serving as guidelines or as reference models for public and private actors in the award, structure and management of PPPs capable of promoting sustainable development objectives.

Therefore, and more in detail, this thesis will be structured as follows. Firstly, an overview of the PPP phenomenon as understood at an International and European level will be provided. PPPs' goals and International and EU legal background will be then identified. As mentioned, this preliminary focus will be necessary to identify the actual rules governing public-private collaborations in the light of the absence of an ad hoc regulation of PPPs at an International and EU level. It will then follow an overview of the implementation of the PPP phenomenon in the Member States studied: the United Kingdom, the Netherlands and Italy. These three jurisdictions were chosen because of the following reasons. The United Kingdom's experience is of key importance in the study of PPPs. The United Kingdom (hereinafter UK) is, in fact, the country where modern PPPs were born, at least in the EU context. Indirect evidence of this is, for instance, the global use of the English language to describe PPP's legal aspects and processes. ${ }^{36}$ The Netherlands (hereinafter NL) represent, instead, an interesting case study because of the high level of PPPs' arrangements carried out if compared to the geographical dimensions of the country. In the NL, PPP

\footnotetext{
${ }^{36}$ By way of example, the English terms 'output' and 'value for money' that are widely used throughout Europe in the PPP context.
} 
schemes were largely exploited in the last decades, specifically in order to enhance local and central infrastructure projects. Finally, Italy represents an example of an EU civil law system highly affected by the international economic crisis, which nonetheless - and remarkably - was capable of redirecting its energies towards the use of PPPs to boost its economic growth. For each jurisdiction, the following aspects will be highlighted: (i) the Government support in the promotion of PPPs, (ii) the PPP types more commonly used and the sectors where they advanced, (iii) the relevant national legal framework and (iv) the main criticalities connected to the use of PPPs.

The mentioned diversity of these Member States' experience with PPPs represents an enriching element for this research. In fact, even with different cultural, legal and policy backgrounds, one common denominator emerged: the need - stressed especially at the European level $^{37}$ - of developing a true strategy for smart, sustainable and inclusive growth, the promotion of a more resource-efficient, greener and competitive economy capable of fostering high-employment, social and territorial cohesion. ${ }^{38}$ It is precisely within this picture that PPPs developed in the considered Member States as important market-based instruments for the achievement of the stated objectives.

Furthermore, Chapter III will explore the concept of sustainable development and its relationship with public procurement. Following the understanding of such relationship, Chapter III will explore the scope for sustainable development considerations within EU public contracts and concessions law in order to identify the potential spaces for sustainability considerations within PPPs, which are a kind of complex public contracts.

Later on, Chapter III will identify PPPs' potential socio-environmental benefits. Specifically, it will be shown how they may present themselves. The large majority of public authorities usually refers to economic analysis in order to evaluate whether to deliver an investment through a PPP or a traditional procurement model. This means that ex-ante feasibility analyses are normally carried out. These, however, focus mainly on the financial costs inherent in the different delivery models with outputs that are considered to be equivalent. Nonetheless, if there are reasons to believe that the socio-environmental benefits related to a delivery under a PPP will be larger than under a classic

\footnotetext{
${ }^{37}$ As mentioned, Europe 2020 is a ten-year growth and job strategy launched in 2010 by the EU. It is a project that aims at overcoming the crisis from which Member States' economies are gradually recovering. It tackles the downsides of domestic growth-models through the establishment of conditions for a smart, sustainable and inclusive growth. The EU set out five objectives to be reached by 2020. These are: (i) achieving 75\% employment of 20-64 year-olds; (ii) ensuring 3\% of the EU's GDP invested in research and development; (iii) reducing greenhouse gas emissions by $20 \%$ or even $30 \%$ compared to 1990 levels, generating $20 \%$ of energy needs from renewables and enhancing our energy efficiency by 20\%; (iv) reducing school dropout rates to below 10\%, with at least $40 \%$ of $30-34$ year-olds completing tertiary education; (v) guaranteeing 20 million fewer people at risk of poverty or social exclusion. Each Member State adopted national targets for each of the above-mentioned objectives. An agreement was reached on a number of concrete actions to be carried out both at EU and domestic levels. The most important areas of action, which are believed to be the new drivers of growth, and jobs boost, were identified. For further details, see, for instance, The EU explained, Europe 2020: Europe's growth strategy, Growing to a sustainable and job-rich future, 2012, available at http://ec.europa.eu/europe2020/pdf/europe_2020_explained.pdf.

${ }^{38}$ This need could be easily addressed by PPPs because of the following reasons. As it will be seen, the planning in advance of all project's phases and the long duration of PPP contracts allow, on the one hand, the incorporation of future maintenance and operating costs and, on the other hand, investments in innovative and sustainable solutions. In addition, PPPs' funding and payment mechanisms allow the public sector to set high quality targets and the private sector to deliver them in the best way. Moreover, a smart allocation of risks and tasks between the private and public sectors allows the delivery of better outcomes.
} 
procurement, public authorities should take this into consideration. ${ }^{39}$ PPPs do have the potential to provide to society environmental improvements, jobs growth and high quality standards, which by the way represent some of the main objectives of Europe's 2020 program. ${ }^{40}$

Moreover, Chapter IV will investigate the scope for sustainability considerations within the relevant policies and legal regimes of the Member States studied in order to identify the actual spaces for sustainable development considerations within PPPs. An empirical analysis will be then carried out. National representative PPP case studies - in terms of their ability to integrate socioenvironmental considerations - will be undertaken. This empirical study will be carried out:

(i) as hardly any case study identifying the concrete strategies through which public and private actors can integrate sustainability concerns within PPPs and, thus, promote sustainable development goals, was found;

(ii) in order to examine whether a theoretical and academic discourse could be validated also on practical grounds; therefore, to investigate if, in the every-day practice, PPPs are actually capable of promoting sustainable development considerations through the integration of sustainability concerns.

Therefore, the empirical study of Chapter IV will highlight - in addition to the specific socioenvironmental benefits delivered by each PPP project - the tender and contractual strategies that allowed the integration of sustainability concerns within the PPPs studied and, thus, the generation of socio-environmental gains.

Eventually, this thesis will provide an overview of the research carried out and a picture of the acknowledgments and achievements obtained through this study along with concluding findings and remarks. Specifically, it will highlight, inter alia, which are the strategies that may be overall used by public and private actors to shape PPP arrangements that promote also sustainable development goals. These generally applicable strategies will aim at serving as guidelines or as reference models for public and private actors in the award, structure and management of PPPs capable of promoting sustainable development objectives.

\section{Delimitation of the study: exclusions and limitations.}

This thesis will approach PPPs exclusively from the perspective of sustainable development promotion. Therefore, it will be investigated only the ability of PPPs to generate socioenvironmental benefits and, thus, their capability to promote sustainable development objectives.

The strategic relevance given by EU institutions to PPP models, the need for economic growth within the Internal Market along with the need to promote sustainable development goals, justify such a focus. As mentioned, academics and practitioners have thoughtfully covered the study of PPPs' economic feasibility, potential financial risks and shortfalls. ${ }^{41}$ Little attention has been,

\footnotetext{
${ }^{39}$ See, for instance, The Non-Financial Benefits of PPPs, A Review of Concepts and Methodology, European PPP Expertise Centre, European Investment Bank, June 2011, available at http://www.eib.org/epec/resources/epec-nonfinancial-benefits-of-ppps-public.pdf.

${ }^{40}$ Communication from the Commission, Europe 2020, A strategy for smart, sustainable and inclusive growth, European Commission, Brussels, 3.3.2010, COM (2010) 2020 final.

${ }^{41}$ The study of PPPs' economic feasibility, financial risks and potential shortfalls will be out of the scope of this research. For an in depth review in this regard, see, among others, J Guasch, J L Laffont, S Straub, "Concessions of infrastructure in Latin America: Government-led renegotiation” [2007] Journal of Applied Econometrics, 22(7), 1267, 13
} 
instead, put on the ability of PPPs to promote environmental and social sustainability when providing public infrastructure and/or service projects. Therefore, this thesis - bearing in mind the possible drawbacks of PPPs as highlighted by practitioners and scholars ${ }^{42}$ - will focus the attention on a different and specific aspect of PPPs, which has not been yet delved into: their ability to generate socio-environmental benefits and, thus, their capability to promote sustainable development.

This work is, thus, intentionally and inevitably not all encompassing. It does not aim at exploring the existing differences between traditional public procurement means and PPPs. It builds from the critical assessment and the existing approach to public provision through PPPs to carry out a study of such complex public contracts under a different light. It is a thesis that aims at opening up the way to a new theoretical understanding of PPPs, supported by empirical findings, whereby PPPs are considered as viable alternatives in the delivery of public services and infrastructure because of their ability to promote sustainable development objectives. This thesis uses an approach to critical issues that departs from the actual state of circumstances in order to generate new knowledge and understanding. In particular, this thesis seeks to explore the ways through which PPPs can actually integrate sustainable considerations within their structure, thus, promoting sustainable development goals. This, with the overall aim of creating a progressive theory secured by empirical evidence.

Therefore, without ignoring the possible PPPs' drawbacks - on the contrary being well aware of the fact that PPPs do not represent the solution to every problem - this study will be carried out in the light of its specific objective: the investigation of PPPs' ability to generate socio-environmental benefits and, thus, to promote sustainable development within the EU. This entails that this study

1294. E Maskin, J Tirole, "Public-private partnerships and government spending limits" [2008] International Journal of Industrial Organization, 26(2), 412, 420. D Heald, G Georgiou, "The Substance of Accounting for Public- Private Partnerships" [2011] Financial Accountability \& Management, 27(2), 217, 247. R Ball, M Heafey, D Kin, "The Private Finance Initiative in the UK" [2007] Public Management Review, 9(2), 289, 310. J Broadbent, J Gill, R Laughlin, "Identifying and controlling risk: The problem of uncertainty in the private finance initiative in the UK's National Health Service" [2008] Critical Perspectives on Accounting, 19(1), 40, 78. D Grimsey, M Lewis, "Public private partnerships and public procurement" [2007] Agenda: A Journal of Policy Analysis and Reform, 14(2), $2007,171,188$. A Ng, M Loosemore, "Risk allocation in the private provision of public infrastructure" [2007] International Journal of Project Management, 25(1), 66, 76. J Broadbent, J Gill, R Laughlin, "Identifying and controlling risk: The problem of uncertainty in the private finance initiative in the UK's National Health Service" [2008] Critical Perspectives on Accounting, 19(1), 40, 78. J Shaoul, “A critical financial analysis of the Private Finance Initiative: selecting a financing method or allocating economic wealth?" [2005] Critical Perspectives on Accounting, 16(4), 441, 471. R Ball, H Maryanne, D King, "The Private Finance Initiative in the UK" [2007] Public Management Review, 9(2), 289, 310. M Pollitt, "The Declining Role of the State in Infrastructure Investment in the UK" in S V Berg (ed), Private Initiatives in Infrastructure: Priorities, Incentives and Performance (Aldershot, Edward Elgar, 2002). Klijn, "Institutional and strategic barriers to public-private partnerships: an analysis of the Dutch case" [2003] Public Money \& Management, 23(3), 137, 146.

${ }^{42}$ See also, D Heald, "Value for money tests and accounting treatment in PFI schemes" [2003] Accounting, Auditing \& Accountability Journal, 16(3), 342, 371. F Blanc-Brude, H Goldsmith, T Valila, Ex-Ante Construction Costs in the European Road Sector: A Comparison of Public-Private Partnerships and Traditional Public Procurement, European Investment Bank, European and Financial Report, 2006/01, available at

http://www.eib.org/attachments/efs/efr_2006_v01_en.pdf. J L Guasch Laffont, S Straub, “Concessions of infrastructure in Latin America: Government-led renegotiation" [2007] Journal of Applied Econometrics, 22(7), 1267, 1294. S P Ho, L Y Liu, "Analytical model for analyzing construction claims and opportunistic bidding" [2004] Journal of construction engineering and management, 130(1), 94, 104. J L Guasch, Renegotiation of concession contracts in Latin America, World Bank Publications, 2003. E Chong, F Huet, S Saussier, F Steiner, "Public-private partnerships and prices: Evidence from water distribution in France" [2006] Review of Industrial Organization, 29(1-2), 149, 169. D Parker, K Hartley, "Transaction costs, relational contracting and public private partnerships: a case study of UK defence" [2003] Journal of Purchasing and Supply Management, 9(3), 97, 108. S P Ho, L Y Liu, "Analytical model for analyzing construction claims and opportunistic bidding" [2004] Journal of construction engineering and management, 130(1), 94, 104. 
will be entirely carried out within this specific scope, moving from the assumption that PPPs have the potentialities of being effective delivery means also of socio-environmental benefits and, thus, that they should be structured through an inclusive approach.

Consequently, EU public contracts and concessions law - as well as the relevant legal regimes of the Member States studied - will be analysed with the specific purpose of identifying the spaces for sustainable development considerations within PPPs.

Along the same lines, the case studies discussed in Chapter IV will aim at investigating the socio-environmental benefits delivered and the concrete ways through which the studied PPP projects integrated sustainability concerns within their structure, thus, promoting sustainable development goals. Therefore, the PPP projects presented in Chapter IV have been chosen according to the following criteria:

i. operational PPPs carried out in the UK, the NL and Italy.

The generation of socio-environmental benefits through PPPs can be investigated only if the considered PPP projects are in the operation and maintenance phase. ${ }^{43}$

Given that the PPPs studied in this thesis had not yet reached the end of the operation and maintenance phase, the end of life of such contracts is out of the scope of this research.

ii. $\quad$ PPPs that promote sustainable development objectives or that implemented sustainability considerations in some or all projects' phases. In order to study how PPP arrangements can integrate sustainability concerns within their structures and, thus, how they can deliver socio-environmental benefits, PPPs promoting sustainable development goals or implementing sustainability considerations in some or all projects' phases, had to be chosen.

Therefore, the case studies that will be presented in Chapter IV seek to enhance the theoretical discussion on the ability of PPPs to foster sustainable development goals when delivering public services and/or infrastructure. It is, in fact, believed that, if PPPs' typical incentives are actually endorsed, PPP arrangements may effectively deliver socio-environmental benefits, thereby promoting sustainable development goals. Undertaking an empirical investigation in this field was deemed as crucial in order to verify how, in practice, socio-environmental benefits can be concretely generated by public-private collaborations, driving the choice for PPPs as effective means of public services and/or infrastructure delivery also in this respect. In this regard, by looking at the best overall quality of projects, the best sustainable public delivery model can be chosen. The case studies that will be described in Chapter IV will show that public authorities may indeed achieve sustainable objectives through the use of PPPs.

\footnotetext{
${ }^{43}$ PPPs' phases are the following: planning phase, tender or procurement phase, realisation phase, operation and maintenance phase. 


\section{5. 'Brexit' and its possible implications on the UK's public procurement market and legal regime.}

When drafting this thesis two main events occurred. First, the transposition by Member States of the 2014 EU public procurement Directives into their national legal systems. This meant that this research - upon a previous knowledge of the 2004 EU public procurement Directives - covered the 2014 Directives as well as their implementation in the Member States studied, which occurred by April 18, 2016. Secondly, on June 23, 2016, the 'Brexit' referendum took place. It asked UK's people whether they wanted the country to continue to be part of the EU. The result was an overall vote to leave the EU.

The extent to which the latter event will affect the UK's public procurement market and legal regime will depend on the future relationship between the UK and the rest of the EU. In fact, the UK - by leaving the EU - would not be any more part also of the WTO GPA, to which the UK is legally bound only as part of the EU as a whole. EU public procurement rules are coordinated with GPA obligations and, hence, compliance with such international rules would allow the UK to keep access to both the EU and GPA markets. Anyway, if the UK decides to rely only on the GPA, it would have to negotiate its membership, without having in the meanwhile access to the relevant market. Moreover, the UK would have to define its commitments towards the EU and other GPA members. In this respect, the UK would likely face pressures to accept stricter obligations than those already existing between the EU and the rest of GPA parties.

Furthermore, the UK - by withdrawing from the EU - will no longer be part of the European Economic Area (hereinafter EEA). However, if the UK obtains an EEA membership in its own right, it would maintain access to the Internal and GPA markets with no considerable changes on the state of art. The EU public procurement Directives are, in fact, legislative texts with EEA relevance and, thus, EEA members must comply with them. If, instead, the UK decides to design its relationship with the EU upon an ad hoc trade agreement it may still keep access to the Internal Market. Nonetheless, the EU would probably stand firm for the UK's maintenance of its existing public procurement law regime, which closely follows EU Directives.

If the relationship between the UK and the EU is not to be based on the UK's membership to the GPA or the EEA and no trade agreement is signed, the UK will lose access to both the Internal and worldwide markets. This would be detrimental to the UK's public procurement system. It would negatively affect the public sector and the business world, especially those companies relying on cross-border procurement trades. In addition, relying on the possibility of creating a new UK's public procurement model would be likely to have negative effects. Transactions costs are higher for companies working in markets where different procurement regimes are in place. British undertakings would have difficulties to export to the EU if they need to apply different regulatory systems. Thus, EU importing companies could buy goods from UK's companies and then sell them to the public sector in the rest of the EU. A new UK public procurement model, which differs from the EU current regime, would also not ease cross-border collaborations with public authorities across the EU and the rest of the world. Additionally, non-UK public and private actors would have to verify that the new system complies with their requirements, thereby slowing down cross-border procurement related trades. Finally, yet importantly, in the transposition of the 2014 EU public procurement Directives, the UK did not demonstrate a high level of creativity. Therefore, it is likely that no clear strategy or direction for the development of a new public procurement regime has been 
developed yet. The Transatlantic Trade and Investment Partnership (hereinafter TTIP) may be mentioned as well. Even though TTIP negotiations seem to be failing, by withdrawing from the EU, the UK would also lose access to an extended US-EU market specifically foreseen under this agreement. Such a market would probably not be accessible by the UK on its own.

Therefore, in order to reduce as much as possible post-Brexit negative effects on the UK's public procurement market, the UK should - at least in the short term - maintain a broad continuity with the existing EU-based legal model. It should keep its system coordinated with the EU public contracts and concessions regime, maintaining as much as possible the status quo ante 'Brexit'. This would, mainly, preserve the possibility (i) of promoting sustainable development concerns through public procurement means; and the chances (ii) of cross-border procurement related trades, without disrupting investments, infrastructure and/or service projects. 


\section{CHAPTER - PUBLIC-PRIVATE PARTNERSHIPS}

\section{Introduction.}

All forms of collaboration between the public and the private sectors which lead to normally complex transactions, long term and high-value contracts in high profile fields, generally fall within the broad notion of PPPs. ${ }^{1}$ PPPs are overall understood as cooperation arrangements undertaken by public authorities and private operators aiming at the funding, construction, renovation, management and maintenance of a public infrastructure and/or service. ${ }^{2}$

The Efficiency Unit of Honk Kong, ${ }^{3}$ a unit of the Chief Secretary for Administration Office established in 1992, ${ }^{4}$ provided a noteworthy description of PPPs identifying six different PPPs' model types. These, can be summarized as follows:

a. The creation of wider markets where assets in terms of skills and funding from the private and the public sectors are used.

b. The Private Finance Initiative where the public party purchases quality services and the private sector constructs and maintains the relevant infrastructure. The private actor delivers the design, building, funding and bears the relevant costs through charges on end-users.

c. The joint venture structure where the private and public sectors put together their assets, finance and expertise under a joint management.

d. Partnerships companies, which bring private sector's ownership into Stateowned businesses by means of legislation, regulation, partnership agreements or holding of a specific government share.

e. Partnership investments where the public sector shares the returns of investments made by the private sector.

f. Arrangements whereby the private sector pays a fee during the concession period awarded by the public authority according to the revenues that the service generates.

PPPs are one of the most studied topics within the so-called nouvelle vague of European public law. ${ }^{5}$ Undoubtedly, they are one of the most fascinating fields. They represent the emerging and merging point of classical legal types of administrative law (e.g. concessions), fundamental principles of EU law (e.g. free competition), comparative issues (e.g. the French service public),

\footnotetext{
${ }^{1}$ As the International Monetary Fund stated, there is no real agreement or consensus on a unique definition of PPPs. See, for instance, B Craig, C Wilson, 'PPPs in the European Union' in N Avery (ed), Public-Private Partnerships: A Practical Analysis (Globe Business Publishing, 2010) 257. G R Teisman, E H Klijn, 'Public-Private Partnerships in the European Union: Officially Suspect' in S P Osborne (ed), Public-Private Partnerships: Theory and Practice in International Perspective (Routledge, 2000) 165.

${ }^{2}$ See the European Commission statement in the Green Paper on Public-Private Partnerships and Community Law on Public Contracts and Concessions, COM (2994) 327 final.

${ }_{4}^{3}$ Further data available at http://www.eu.gov.hk/en/index.html.

${ }^{4}$ The mission of this Unit is to provide departments with high quality management consultancy services and promote the provision of world-class public services to the people of Honk Kong.

${ }^{5}$ In this respect, see, for instance, G C Feroni, Il Partenariato Pubblico-Privato: Modelli e Strumenti (Giappichelli, 2011) 23. 
critical rethinking of consolidated legal categories (e.g. the distinction between private and public law) and interpretative criteria of EU law provisions, which are often the result of Member States' legal categories (e.g. the EU notion of service concession that comes from the French experience).

From another perspective, PPPs are considered as effective tools of economic policy choice and, especially in circumstances of serious budget restraints and financial crisis, they are seen as essential tools. In a situation of crisis, as the one that we have been experiencing since 2008, PPPs are normally engaged for the realization of public infrastructure and/or service projects, to promote and boost the economic development of a country. In this regard, the European Commission expressed itself in its Communication of $2009^{6}$ meaningfully entitled 'Mobilising private and public investment for recovery and long term structural change: developing Public-Private Partnerships.' PPPs are, in fact, cooperation arrangements that allow normally large financial resources to be directed towards the funding of public infrastructure and/or services, key elements in the long-term growth of any economy and, in the European context, of the Internal Market. ${ }^{7}$ In fact, overall, society's prosperity and well-being depends on infrastructure projects, such as ports, highways, water systems, pipelines, hospital and schools. $^{8}$ They assure transportation, facilitate communication, deliver energy and water, promote health-care and education allowing the whole economy of a concerned area to flourish. Indeed, infrastructure costs are high, but the costs of failing to invest on them are even higher. ${ }^{9}$ It is within this picture that public-private collaborations slowly re-emerged and became crucial in the provision of public infrastructure and services. PPPs are conceived as economically effective alternatives in the delivery of complex capital projects, which need a considerable on-going maintenance. Yet, up to now few Member States have fully discovered and exploited PPPs. Most of them have still little experience in the use of this multifaceted legal category. ${ }^{10}$

While market and policy makers' attention on PPP projects is fairly recent, ${ }^{11}$ private investments in public infrastructure is an old phenomenon. Already back in the eighteenth century, European countries were experiencing the participation of private investors in the provision of public infrastructure and/or services. For instance, in France, a concession contract delivered

\footnotetext{
${ }^{6}$ Communication from the Commission to the European Parliament, the Council, the European Economic and Social Committee and the Committee of the Regions, 'Mobilising private and public investment for recovery and long-term structural change: developing Public Private Partnerships', Brussels, 19.11.2009, COM (2009) 615 final.

${ }^{7}$ See, What Makes Public-Private Partnerships Work? An Economic Analysis, J Bensaid, F Marty, Prisme, n. 27, Cournot Centre, 2014, available at http://www.osservatorioappalti.unitn.it/content.jsp?id=31. S E Pommer, 'Public-Private Partnerships' in M Trybus, R Caranta, G Edelstam (eds), EU Public Contract Law, Public Procurement and Beyond, (Bruylant, 2014) 285 et ss.. N Budina, H P Brixi, T Irwin, Public Private Partnerships in the New EU Member States: Managing Financial Risks (World Bank Working Papers, 2007).

${ }^{8}$ See, A Akintoye, E Chinyio, 'Private Finance Initiative in the Healthcare Sector: Trends and Risk Assessment' [2005] Engineering Construction and Architectural Management, 601, 616.

${ }^{9}$ In this respect, see the World Economic Forum, Global Agenda Council on Infrastructure 2012-2014, available at https://www.weforum.org/reports/global-agenda-council-infrastructure-2012-2014/.

${ }^{10}$ T M Nisar, 'Implementation Constraints in Social Enterprise and Community Public-Private Partnerships' [2013] International Journal of Project Management, Elsevier, 638, 651.

${ }^{11}$ At the earliest in the $90 \mathrm{~s}$ in the UK. 
drinking water to Paris. ${ }^{12}$ In the nineteenth century, similar cases were found - outside Europe ${ }^{13}$ - in American and Asian countries. ${ }^{14}$

Traditionally, States have had three main alternatives to procure or develop their public infrastructure or provide public services. First, construction on their own of the relevant facilities and the provision of public goods or services by means of their own powers, and so an in-house or direct public sector provision. Second, the use of the private market productive forces through traditional public sector procurement, and so public work or service contracts. Third, the handing over $^{15}$ to the private sector - for instance by means of PPP arrangements - of the general responsibility of both the planning of the project, the construction of the infrastructure and/or provision of the service. Thus, PPPs represent one of the three main alternatives through which public authorities can deliver public services and/or infrastructure.

Due to States' lack of budgetary funds and technical expertise, this third way is increasingly taken. PPP contracts are getting used to tackle States' shortfalls because they allow private sector's funding, managerial and technical know-how to fill in the actual deficiencies of the public sector abilities. ${ }^{16}$ Therefore, PPP schemes generally emerge when:

- States are dysfunctional and under oppressive fiscal constraints, incapable also with regard to technical skills - of fulfilling their public duties; and

- there is a pressing need for new high quality public works and/or services delivery.

PPPs have the potential to effectively address and reduce such tension by means of public goods or service provision that includes private sector's expertise and funds.

Internationally, the attention is kept on actions capable of addressing the need for public infrastructure and/or service provision. Substantial reinvestments are needed, for instance, in ageing infrastructure in order to deal with - especially in developing countries - population growth, increasing urbanization and policies that are driving a strong demand for new infrastructural spending. This trend, along with the actual financial conditions - which are worldwide severely constraining public budgets - is leading to a wide gap of almost $\$ 2$ trillion annually between demand and investment in infrastructure for the next 20 years. ${ }^{17}$ Studies have shown that $\$ 57$ trillion infrastructure investments should be carried out before 2030, meaning an increase of $60 \%$ compared to the equivalent period until today. ${ }^{18}$ Moreover, according to the World Economic Forum findings, ${ }^{19}$ there is a need for infrastructure projects for almost the $15 \%$ of GDP in order to

\footnotetext{
${ }^{12}$ L Y Tang, Q Shen, E W L Cheng, 'A review of Studies on Public-Private Partnerships Projects in the Construction Industry’ [2010] International Journal of Project Management, Elsevier, 683, 694.

${ }^{13}$ For instance, the Suez Canal and the Trans-Siberian Railway, but also canals, turnpikes and railroads throughout Europe.

${ }^{14}$ In the United States, China and Japan. See M M Kumaraswamy, D A Morris, 'Build-Operate-Transfer Type Procurement in Asian Megaprojects' [2002] Journal of Construction Engineering and Management, 93, 102.

${ }^{15}$ Typical outsourcing contracts are DB (Design, Build); DBO (Design, Build, Operate); DBFO (Design, Build, Finance, Operate); BOO (Build, Own Operate); BOOT (Build, Own, Operate, Transfer).

${ }^{16}$ J Kitsos, 'Construction Investments in Public Works through Public Private Partnerships' [2014] EPPPL, $202,208$.

${ }^{17}$ For further data, see the World Economic Forum, Global Agenda Council on Infrastructure 2012-2014, op. cit..

${ }^{18}$ As noted, for instance, D Podhraški, 'Real Options in Public-Private Partnerships' [2014] EPPPL, $164,173$.

${ }^{19}$ The World Economic Forum periodically publishes comprehensive series of reports, which examine in detail a broad range of global issues addressing them with the relevant stakeholders. 
attain the $7 \%$ annual growth required to meet the Millennium Development Goals of Africa. ${ }^{20}$ The 2030 Agenda - comprising 17 new Sustainable Development Goals - replaced on September 2015 the mentioned Millennium Development Goals, which in September 2000 gathered the world around a common 15-year agenda to tackle the indignity of poverty. The objective of the new Sustainable Development Goals is to produce a set of universally applicable goals to balance the three dimensions of sustainable development: environmental, social and economic. In this respect, PPPs indeed have the capabilities to enter into the scene and work as effective tools capable of dealing with today's lack of public funding and need for economic and sustainable growth. ${ }^{21}$

In the European Union, the PPP phenomenon fits within the process of public sector regulation. Its re-emergence and application is clearly changing public services and especially the way in which they are organised, financed and delivered to end-users. This is because PPPs' approach entails involving the private sector as a strategic and innovative planner, investor, financier, constructor, manager and direct deliverer of services and/or infrastructures that aim at fulfilling the public interest.

\section{The Public-Private Partnership Phenomenon.}

Figure 1 shows how the private sector's involvement can concretely present itself: through either outsourcing or PPP schemes, which in turn can be of various forms and types.
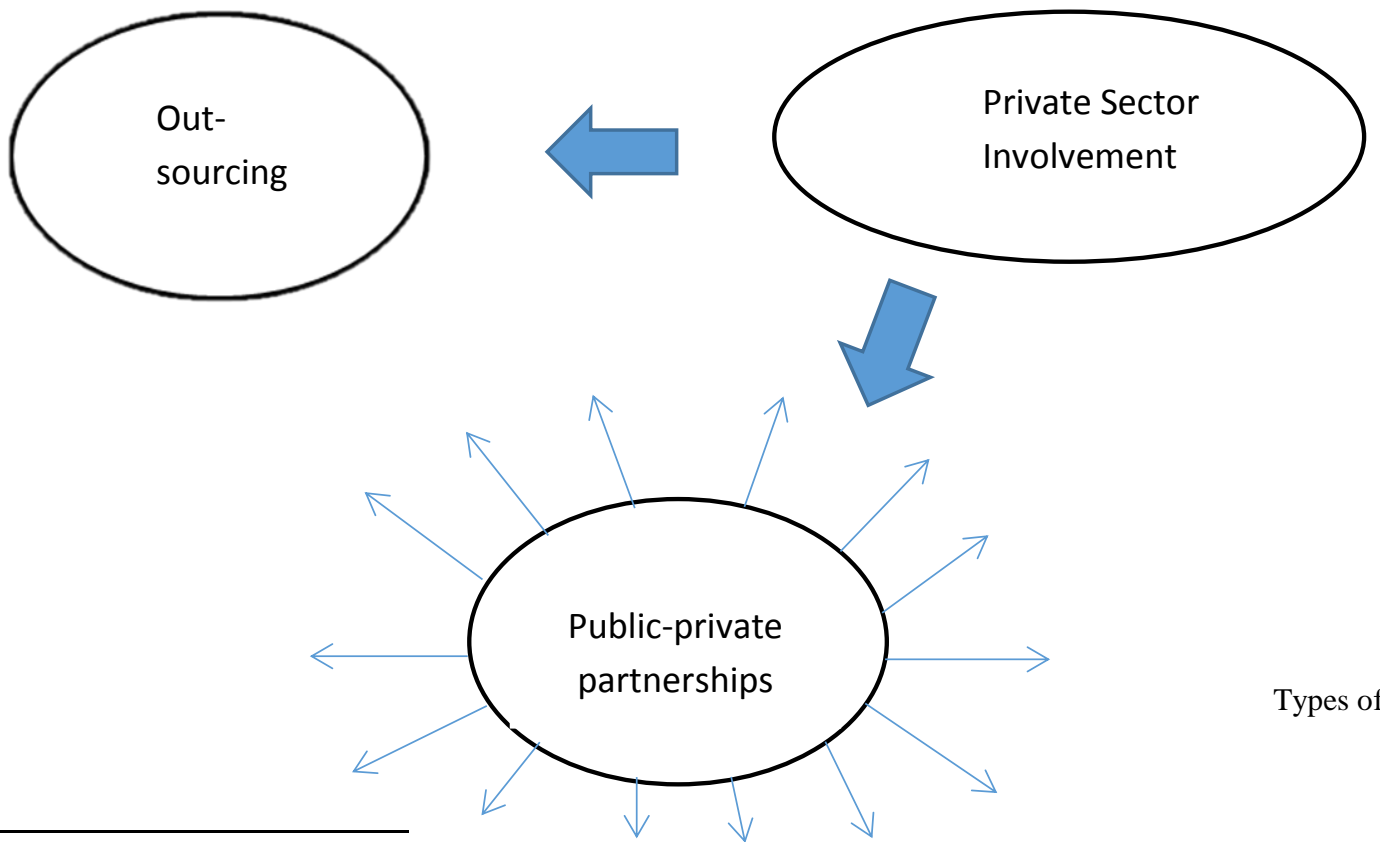

Fig. 1

Types of private sector's involvement.

\footnotetext{
${ }^{20}$ On September 25, 2015, at the United Nations of New York, the 2030 Agenda for Sustainable Development was adopted. This ambitious agenda on Sustainable Development Goals (SDGs) was agreed by 193 countries in September 2015. The 2030 Agenda comprises 17 new SDGs, or Global Goals, which will guide policy and funding for the next 15 years. The concept of the SDGs originated at the United Nations Conference on Sustainable Development, Rio+20, in 2012. The objective was to develop a set of universally applicable goals that balanced the three dimensions of sustainable development: environmental, social, and economic. The Global Goals replaced the Millennium Development Goals (MDGs), which in September 2000 gathered the world around a common 15-year agenda to tackle the indignity of poverty. The MDGs established measurable, universally agreed objectives (considered as development imperatives). The MDGs drove progress in several important areas with a shift on a sustainable path. The new development agenda applies to all countries, aims at promoting peaceful and inclusive societies, creating better jobs, tackling environmental challenges, particularly climate change.

${ }^{21}$ See, Meeting the Infrastructure Challenge with Public-Private Partnerships: Bridging the Gap, M Airoldi, J Chua, P Gerbet et all (eds), The Boston Consulting Group, 2013, available at http://www.bcg.de/documents/file128534.pdf. 
The PPP phenomenon is a form of outsourcing with its own peculiarities and specific features. ${ }^{22}$ Both outsourcing and PPPs entail a strategic use of private resources to perform activities traditionally handled by the public sector. However, PPPs differ from general outsourcing arrangements mainly in terms of goals and governance.

In terms of goals, outsourcing is foremost directed towards efficiency gains. Outsourcing, in fact, allows the public sector to be more efficient, while generally reducing costs. The public sector identifies a problem, defines the solution and selects a private company that can achieve that result in a cost-efficient way. ${ }^{23}$ Hence, outsourcing benefits regard efficiency aspects, such as delivery of an asset in a quicker and cheaper way. PPPs are, instead, mainly aimed towards the improvement of effectiveness. $^{24}$ PPPs' objective is to increase effectiveness through a public-private synergy that delivers an enriched output.

In terms of governance, outsourcing is characterised by a principal-agent relationship. A principal-agent relationship comes into existence whenever one party engages another to perform certain aspects of a work for a consideration and a contractual arrangement manages their relation. Between the outsourcer and the provider, there is a principal-agent relationship regulated by the relevant contract. $^{25}$ The latter sets clear goals and well-defined project specifications. PPPs' governance involves, instead, a joint decisions-making process and a relationship that last throughout the entire life of the contract. ${ }^{26}$ Mutual trust usually characterises PPPs' relationships and each party maintains its own interests, ways of working, accountability and financing principles.

Traditionally, public entities have counted more on internal delivery. Thus, on in-house service provision in support of public sector's functions ${ }^{27}$ delivered directly to the public. ${ }^{28}$ The public sector employed its own construction and maintenance teams, especially for routine or minor works. Over the last twenty years, the balance, however, shifted towards the external provision outsourcing and PPP arrangements - of public services and goods thanks also to the support of central government's policies and legislative measures. ${ }^{29}$

Undoubtedly, outsourcing in general has a range of positive advantages. First of all, it may be used as a strategic alternative when there are services that are not the public sector's core business

\footnotetext{
${ }^{22}$ In the United Kingdom practitioners and academics commonly use the terms outsourcing, contracting out and publicprivate partnership as synonymies. Outsourcing entails normally short-term contracts where only some components of a public service are bought in the market (e.g. the hiring of a cleaning company). With PPPs, some components of a public service (e.g. the construction of the infrastructure needed for service provision), or the whole public service, are contracted out to a private operator through medium or long-term contracts with the public sector monitoring the service provision.

${ }^{23}$ In fact, some of the main advantages brought by outsourcing are staff flexibility, knowledge transfer to permanent staff and the possibility to free internal resources for other purposes. The term cost-efficiency generally refers to the act of saving money by performing an activity in the best way.

${ }^{24}$ See M Walther, Partnering Capacity in White-Collar Public-private Partnerships, 2009, University of St. Gallen, 26, available at

http://www1.unisg.ch/www/edis.nsf/SysLkpByIdentifier/3580/\$FILE/dis3580.pdf.

${ }^{25}$ Keys to success are clear definitions of goals, rules on tendering, selection and delivery.

${ }^{26}$ For instance, goals, funding schemes, realization and utilization are subject to joint decision-making in PPPs. Key characteristics of PPPs are interconnected goals, rules on ongoing cooperation and suitable assignments along with joint efforts and delivery commitments.

${ }^{27}$ Such as accounting and office cleaning.

${ }^{28}$ Such as, for instance, paying benefits, refuse collection, street cleaning and healthcare.

${ }^{29}$ At the European level, see, for all, Sue Arrowsmith, The Law of Public and Utilities Procurement, Regulation in the EU and $U K$ (Sweet \& Maxwell, 2014).
} 
or expertise. In fact, normally the most required and outsourced services are non-core public services. Thus, services usually not related to the fundamental policy-making functions of the public sector and not crucially important in service-delivery terms. In this case, the public sector is interested in concentrating its efforts on other provisions. ${ }^{30}$ Outsourcing these kinds of services allows the public sector to focus on its core tasks of general policy development, education and healthcare service delivery. Therefore, it can be argued that outsourcing well fits within a working and developed market.

Secondly, economic efficiency reasons support outsourcing mechanisms. Economic efficiency reasons are key drivers of contracting out policies and the main goals of today's large majority of public authorities. In this regard, several indicators are proving that the private sector is more economic-efficient. ${ }^{31}$ For instance, the competition incentive and the profit-motive driver. Moreover, the private sector is believed to be normally faster in implementing operational changes in order to meet developing demands. The private sector is also usually considered capable of providing better productivity through innovation and investment in technology. ${ }^{32}$

Furthermore, outsourcing may provide quality improvements because it entails a careful definition of service specifications leading to a greater attention in the formulation and monitoring of quality standards. The latter have to be normally met by external and internal providers while the monitoring is typically carried out by the contracting authority or by an external body. Nonetheless, there are still elements that hinder the realisation of the full potentials of contracting out schemes. Difficulties may arise in the monitoring and enforcement phase of complex arrangements, thereby challenging the provision of adequate quality standards. Moreover, if the public service's aim is not adequately pursued - and it is replaced by a profit motive - a tendency towards lower quality services' provision may rise. Furthermore, preserving competition might be difficult if private bidders submit low bids to hinder in-house capability to provide services. Thus, the initial savings would not reflect the efficiency gains. In addition, if the public sector loses its in-house capacity it becomes reliant on private operators for the provision of services and/or infrastructures, exposing itself to the risk of market failures. Finally, difficulties for outsourcing options may arise from private companies' inexperience in certain new public provisions, if they bid too low or were too ambitious. These concerns are still open issues in today's designing of appropriate contracting out policies and hence also in the structuring of well-functioning PPP schemes.

\subsection{Public-Private Partnership's Definition at an International Level.}

At an International level, there is no unique or widely accepted definition of PPPs. ${ }^{33}$ There are, instead, a number of commonly acknowledged features pertaining to the PPP category as a whole. First of all, it is recognized that the term PPP encompasses a variety of types of legal forms of collaboration between the private and the public sectors for the realization of activities that pursue the public interest. As a result, PPPs have in practice different levels of formalizations. Moreover, it

\footnotetext{
${ }^{30}$ Services that are often outsourced are, for instance, back-office administrative services, facility management activities such as maintenance, cleaning and catering. See, among others, R Mclvor, The Outsourcing Process, Strategies for Evaluation and Management, (Cambridge University Press, 2005) 7 et ss..

${ }^{31}$ In this respect, see Sue Arrowsmith, The Law of Public and Utilities Procurement, Regulation in the EU and UK, op. cit..

${ }_{32}^{3}$ Ibid..

${ }^{33}$ The term PPP is undoubtedly and clearly vague. It is believed that the elusive nature of such a term leaves room for negotiation of rules and practices applicable to partnerships. 
is agreed that the objective of a public-private cooperation is in general terms the creation of a partnership between the public and private sectors in order to deliver infrastructure and/or services to the public. In this respect, the degree of involvement of the private partner - attaining foremost to financing aspects and expertise - depends on the specific features of the PPP project. Given that PPPs are complex transactions leading to long duration, ${ }^{34}$ high-value contracts in high profile sectors, an adequate length of time is usually foreseen to ensure investment and profit recovery. In addition, it is generally understood that the typical long term commitments of these programs to which contracting authorities are normally bound according to PPP contracts, usually represent for the public sector an incentive to choose and invest in more rational and long-term projects and, for the private partner, another reason to plan and deliver more coherent public investment programs.

Thus, even though at an international level there is no consensus on a unique definition of PPPs, it is widely acknowledged that this legal category implies various ideological and managerial choices that are firmly connected to the relationship established between the private and public actors involved and the costs and benefits of the different public-private solutions. ${ }^{35}$

When discussing the PPP notion, it has been argued that:
'the greatest divide seems to be between researchers who view public- private partnerships as a tool of governance and those who think of it as a language game. 36

At a supranational level, PPPs are often used to serve specific strategies and/or agendas such as privatization or the promotion of private suppliers of public goods and/or services on behalf of the public sector. In this regard, terms such as alternative delivery systems or PPPs, push private entities to participate to the market share of public services and infrastructure provision. ${ }^{37}$ Under the language game perspective, the focus shifts, instead, on public policy analyses. Hence, on how public authorities intentionally modify policies in order to obtain the necessary political support. Language games are a key discourse in public policy debates and if applied to the PPP context, they allow public authorities of different States and jurisdictions to conceive PPPs in different ways.

Moreover, when PPPs are perceived as organizational and financial arrangements, the benefits enjoyed by the private and public sectors are regarded as central. Given that both sides have specific skills and capabilities, whenever these are combined it is believed that there is potential for an overall improved outcome. Hence, cooperation and allocation of risks are the main reasons why public and private actors get involved in a PPP. ${ }^{38}$

According to certain literature, PPPs if seen under the said light are:

\footnotetext{
${ }^{34}$ Medium term PPPs last less than 25 years, long term PPPs even over 30 years.

35 See, S H Linder, P Vaillancourt Rosenau, 'Mapping the Terrain of the Public-Private Policy Partnership' in P. Vaillancourt Rosenau (ed), Public-Private Policy Partnerships (MIT Press, 2000), 1, 18.

${ }^{36}$ See G Teiseman, E H Klijn, 'Partnerships Agreements: Governmental Rhetoric or Governance Scheme?' [2002] Public Administration Review, v. 62, n. 2, 197, 205. G A Hodge, C Greve, 'Public-Private Partnerships: an International Review' [2007] Public Administration Reviews, 33, 39, available at https://www.researchgate.net/publication/227691342_Public-Private_Partnerships_An_International_Review.

${ }^{37}$ E S Savas, Privatization and Public-Private Partnerships, (Seven Bridges Press, 2000).

${ }^{38}$ See, S H Linder, P Vaillancourt Rosenau, 'Mapping the Terrain of the Public-Private Policy Partnership' op. cit. 1, 18.
} 
' a cooperation of some sort of durability between public and private actors in which they jointly develop products and services and share risks, costs, and resources which are connected with these products. ${ }^{39}$

From this definition, PPPs' key features emerge: enduring duration, risk sharing and cooperation between the private and public sectors aiming at obtaining benefits from mutual efforts. During the last decade, the PPP phenomenon globally expanded in many fields falling within the public sector's scope. Among all, the infrastructure sector is the field where PPPs schemes mostly developed.

In this regard, PPPs are defined as:

'arrangements where the government states its need for capital-intensive, long-lived infrastructure and the desired facility is built using a complex combination of government and (mostly) private financing and then operated by a private entity under a long-term franchise, contract or lease. ${ }^{40}$

Internationally, in the infrastructure sector, PPPs are seen as advanced alternative forms of public delivery. Private sector's contractors are increasingly providing States' public infrastructure. They undertake the project's financing ${ }^{41}$ and entrepreneurial risk, during the entire contract life, which is of normally 25-30 years. The private party is repaid of its investment, either directly from the contracting authority upon an availability and/or performance basis, ${ }^{42}$ or indirectly from end-users through fees or tools. Otherwise, there is a combination of both paying mechanisms. Moreover, the State may retain property rights on the constructed infrastructure, but can also explicitly grant to the private contractor rights for its operation, management and commercial exploitation. ${ }^{43} \mathrm{~A}$ contractor consortium may be formed by the private sector in order to claim the award of a specific public work, the so-called Special Purpose Vehicle (hereinafter SPV) that will carry out the project.

PPPs, as known today, are believed to be the result of a three-generation process. ${ }^{44}$ The first generation was characterised by several mistakes in the use of PPPs because of the lack of expertise of the public and private sectors involved and of their respective consultants. The second generation of PPPs saw big development companies focused on specialized PPP growth projects and on their management on behalf of the public party. The third generation of PPPs arose after social

\footnotetext{
${ }^{39}$ H Van Ham, J Koppenjan, 'Building Public-Private Partnerships: Assessing and managing risks in port development' [2001] Public Management Review, 3 (4) 598.

${ }^{40}$ E S Savas, Privatization and Public-Private Partnerships, op. cit., 7.

${ }^{41}$ See, E R Yescombe, Public Private Partnerships: Principles of Policy and Finance (Elsevier, 2007);

${ }^{42}$ Being this the English Private Finance Initiative model. See below paragraph 5.1.1. for further details.

${ }^{43}$ N Stern, H P Lankers, Making the Most of Markets: the Role of IFIs, in International Financial Institutions in the $21 \mathrm{st}$ century, European Investment Bank Papers, Vol. 3, n. 2, 1998, 102, 114, available at http://www.eib.org/attachments/efs/eibpapers/eibpapers_1998_v03_n02_en.pdf.

44 L B Sagalyn, 'Public Private Development: Lessons from History, Research and Practice' [2007] Journal of the American Planning Association, vol. 73, (1), 7, 22. 
development. ${ }^{45}$ In this phase, PPPs began to be used by social developers in search of private sector's involvement. Today, we are assisting to an expansion of this latter generation.

As already mentioned, at an International level there have been attempts at defining the PPP phenomenon. For instance, the World Bank provided its own PPP's definition by holding that it consists of a:

' a long-term contract between a private party and a government entity, for providing a public asset or service, in which the private party bears significant risk and management responsibility, and remuneration is linked to performance. ${ }^{46}$

Worth mentioning is another enriching attempt at defining the PPP phenomenon carried out by the United Nations Development Programme. The latter, when focusing on PPPs for the Urban Environment, highlighted that the definition of PPPs should be broad enough to include also informal dialogues between government officials and local community-based organizations, which remarkably are considered essential for effective PPPs. ${ }^{47}$

Furthermore, the OECD considers PPPs as:

'long-term contractual arrangements between the government and a private partner whereby the latter delivers and funds public services using a capital asset, sharing the associated risks. ${ }^{48}$

Therefore, as already mentioned, at an International level there is no real agreement on a unique definition of PPPs. This is mainly because of the different legal traditions existing throughout the world. A wider consensus, instead, surrounds PPPs' features and goals. The rise of PPPs, in fact, occurred after a global policy change, namely the shift of the role played by the public sector. States began stepping back from the typical sectors where they once exercised and imposed their sovereignty, often through the creation of monopolies. PPPs entered into the scene when States became service purchasers, while once being service providers.

\footnotetext{
${ }^{45}$ Social development may be described as a process of change from a traditional way of living of rural communities to progressive ways of living. It is a process where people are assisted in the development of themselves, of their own capacities and resources. Social development is concerned with the investment on human beings, education, health, social welfare, etc. Social development is directed towards the global development of people. It is an inter-sectorial, inter-regional and inter-disciplinary process aiming at institutional and structural reforms that can provide greater social justice.

${ }^{46}$ Asian Development Bank, Inter-American Development Bank, World Bank Group, Public-Private Infrastructure Advisory Facility, Public-Private Partnerships Reference Guide: Version 2.0, second edition, July 2014, 14. Full text available at https://ppp.worldbank.org/public-private-partnership/library/public-private-partnerships-reference-guideversion-20.

${ }^{47}$ E Bennett, P Grohmann, B Gentry, United Nations Development Programme (UNDP), Yale University and PPPUE, Public-Private Partnerships for the Urban Environment, Options and Issues, New York, 1999, Working Paper Series Volume I, available at http://www.ucl.ac.uk/dpuprojects/drivers_urb_change/urb_infrastructure/pdf_public_private_services/UNDP_PPPUE_Joint\%20Venture_1.pdf. ${ }^{48}$ OECD, Recommendation of the Council on Principles for Public Governance of Public-Private Partnerships, 2012 available at https://www.oecd.org/governance/budgeting/PPP-Recommendation.pdf. 


\subsection{The Definition of Public-Private Partnerships at the European Level.}

Also at a European level the term PPP has not been defined. Comparative analyses on the implementation of PPPs in various Member States display a heterogeneous and complex universe where a vast variety of definitions, categories and models fall within the notion of PPP. The term PPP is, in fact, broadly used to describe different types of contractual arrangements. ${ }^{49}$ It is understood in different ways according to the Member State, the country context, the sector, the different legal, regulatory and investment considerations involved, the specific market structure, industry, organization and project-related features. Hence, in Europe, PPPs come in a wide variety of models and legal types ranging, for instance, from concession contracts to joint ventures.

Remarkably, the 2004 Green Paper on Public-Private Partnerships ${ }^{50}$ (hereinafter the Green Paper) did not lay down a legal definition of PPPs, but the essential traits that the formulas through which PPPs present themselves should have. In addition, it anticipated the critical issues related to their application. According to the European Commission, PPPs are characterized by the following elements:

i. a long lasting relationship that involves cooperation between a public and a private partner on various aspects of a planned project. The long duration of a PPP is primarily due to the fact that the private sector needs to repay its investments.

ii. the funding of the project, which normally comes from the private sector and is usually the result of complex arrangements between various stakeholders. Public funding which in some cases is quite significant - may be provided in addition to private funds;

iii. the vital role of the economic operator that participates at various stages of the project: designing, construction, management and maintenance. The role of the public sector is, instead, the identification of the goals to be achieved in the light of the public interest and the quality of the service to be provided. In addition, the public sector identifies the pricing policy and monitors the compliance with the set goals;

iv. the allocation of risks between the public and the private sector. Risks are allocated to the partner who is better capable of bearing them. This means that the private partner does not necessarily take all risks. Their precise distribution is decided on a case-by-case basis depending on the parties' ability to assess, control and deal with them.

\footnotetext{
${ }^{49}$ For instance, the BOT (Build-Own-Transfer) and BOOT (Build-Own-Operate-Transfer) contracts where the only difference is the management of the infrastructure before the transfer back to the public sector. According to the BOOT scheme the private actor builds the infrastructure, operates it during the concession period and, at the end, it transfers it to the public party without consideration. Moreover, reference can be made to sale and lease back agreements under which local public bodies sell buildings and then rent them back through a 20-30 year contract from a financial entity. $G$ Hodge, C Greve, 'Public-Private Partnerships: an International Review' [2007] Public Administration Review, 546.

${ }^{50}$ Green Paper on Public-Private Partnerships and Community law on Public Contracts and Concessions, COM (2004) 327 final.
} 
The picture of the PPP phenomenon that arises out the Green Paper's considerations is broken into two different legal categories: contractual and institutionalised PPPs. This distinction reflects two different types of PPPs where the inner criticalities are often the same and related to the application of EU public contracts and concessions law. ${ }^{51}$ The first type of PPPs are partnerships based merely on contractual relations linking together the different actors involved. This type of PPPs can be setup in various ways, all characterised by the fact that one or more tasks are allocated to the private sector. These, can include the design, funding, execution, renovation or exploitation of a work or of a service. Overall, it is the case of public works and services concessions, which today can count on an EU regulation thanks to the enactment of Directive 2014/23/EU. ${ }^{52}$ According to the Commission, concession schemes are characterized by a direct relationship between the private partner and end-users. The private operator provides a service to the public on behalf of - but under the control of - the public partner. Another characterizing element is the private sector's compensation that comes from end-users, combined, if needed, with public funds. ${ }^{53}$ In addition, the Commission remarked that the private partner's selection procedure cannot limit the principle of free competition or assure the project promoter a competitive hedge that may affect bidders' equal treatment. At the same time, it highlighted that the principles of equal treatment between economic operators and the principle of transparency have to be respected also after the contractual award, hence in the phase of construction and management of the service. ${ }^{54}$

Other levels of formalization of contractual PPPs are those where the private actor builds and manages infrastructure or provides a service for the public sector, e.g. a school, a hospital, a prison or a transport facility. The Private Finance Initiative (hereinafter PFI) model is an example of this kind of purely contractual PPP. In this case, the private sector's remuneration is based on the public sector's regular payments, which can be either fixed or calculated in an adjustable way, according, for instance, to the availability of the work or service provided or to the usage-level of the work or service.

The term institutionalised PPPs (hereinafter IPPPs) refers, instead, to the creation of an entity jointly held by the private and public partner, namely a SPV, which provides a service or an infrastructure to the benefit of the public. ${ }^{55}$ This PPP type allows the public and private sectors to cooperate within an entity that has a legal personality, thus enabling the public sector - thanks to its presence in the body of shareholders and in the decision-making structure - to have quite a high degree of control in the development of the PPP project. This may ease contract changes that might become necessary during the project evolution. ${ }^{56}$ It can also allow the public sector to acquire its

\footnotetext{
${ }^{51}$ See below Chapter II, paragraph 4.2..

${ }^{52}$ Directive 2014/23/EU of the European Parliament and of the Council of 26 February 2014 on the award of concession contracts, 28.3.2014, Official Journal of the European Union L 94/1. See below Chapter II, paragraph 4.2.4.2..

${ }^{53}$ Green Paper on Public-Private Partnerships and Community law on Public Contracts and Concessions, COM (2004) 327 final, point 22

${ }^{54}$ Green Paper on Public-Private Partnerships and Community law on Public Contracts and Concessions, COM (2004) 327 final, points 42 and following.

${ }^{55}$ Still few Member States use this kind of PPP model to provide infrastructures at a local level, as in the case of water supply services or waste collection services Green Paper on Public-Private Partnerships and Community law on Public Contracts and Concessions, COM (2004) 327 final, 18.

${ }^{56}$ It must be borne in mind that EU public procurement Directives limit contract changes by indicating the extent to which they can be modified.
} 
own managing expertise through the day-to-day collaboration with the private partner. Finally, IPPPs may also be set-up with the private sector taking control of a public company.

Thus, also at a European level the term PPP has not been yet defined. As seen, characterising indicators and two macro legal categories have been identified, leaving to each Member State the precise definition and regulation of the different legal formalizations.

\section{Public-Private Partnerships' Goals.}

In terms of objectives pursued, PPPs are first of all perceived as legal tools capable of delivering public infrastructure and/or services through an enhanced partnership between the public and the private sectors. ${ }^{57}$ PPPs, in fact, aim at obtaining an effective risk management ${ }^{58}$ of a project and a clear prior identification of critical success factors, ${ }^{59}$ along with an adequate financial analysis according to the specific public asset and/or service that has to be delivered. ${ }^{60}$ One of the central goals of PPPs is to save resources and to use those available in an efficient manner. This is done in different ways. For instance, the public sector concentrates on its best skills without using its resources for the realization of projects where it has no expertise.$^{61}$ Public assets are efficiently used and public services and/or infrastructures are delivered with a final improved overall quality. ${ }^{62}$ In addition, it is believed that a smart use of private sector's skills, expertise, funding, technology and innovation can support the achievement of high quality standards. Risk sharing at various stages of a project entails less risk of cost overruns and project's delays. ${ }^{63}$

\footnotetext{
${ }^{57}$ X Q Zhang, M M Kumaraswamy, 'Hong Kong experience in managing BOT projects' [2001] Journal of Construction Engineering and Management, 154, 162. A Erridge, J Greer, 'Partnerships and public procurement: building social capital through supply relations' [2002] Public Administration, 503, 522. X Q Zhang, M M Kumaraswamy, W Zheng, E Palaneeswaran, 'Concessionaire selection for build-operate-transfer tunnel projects in Hong Kong' [2002] Journal of Construction Engineering and Management, 155, 163. X Q Zhang, 'Improving concessionaire selection protocols in public-private partnered infrastructure projects' [2004] Journal of Construction Engineering and Management, 670, 679. X Q Zhang, 'Concessionaire selection: methods and criteria' [2004] Journal of Construction Engineering and Management, 235, 244. T Ysa, 'Governance forms in urban public-private partnerships' [2007] International Public Management Journal, 35, 57.

${ }^{58} \mathrm{D}$ Grimsey, M K Lewis, 'Evaluating the risks of public-private partnerships for infrastructure projects' [2002] International Journal of project Management, 107, 118. B Li, A Akintoye, P J Edwards, C Hardcastle, 'The allocation of risk in PPP/PFI construction projects in the UK' [2005] International Journal of project Management, 25, 35. L Y Shen, A Platten, X Deng, 'Role of public-private partnerships to manage risks in public sector projects in Hong Kong' [2006] International Journal of project Management, 587, 594.

${ }^{59} \mathrm{~B} \mathrm{Li}$, A Akintoye, P J Edwards, C Hardcastle, 'Critical success factors for PPP/PFI projects in the UK construction industry’ [2005] Construction Management and Economics, 459, 47.

${ }^{60}$ A Saunders, 'Aspects of funding for BOO projects' [1998] Engineering, Construction and Architectural Management 22, 30. S R Norwood, N R Mansfield, 'Joint venture issues concerning European and Asian construction markets of the 1990's' [1999] International Journal of Project Management, 89, 93. A Akintoye, M Beck, C Hardcastle, 'Introduction: public-private partnerships in infrastructure development' in A Akintoye, M Beck, C Hardcastle (eds), Public-private partnerships: managing Risks and Opportunities, (Blackwell Science Ltd, 2003) xix-xxiv. A Akintoye, M Beck, C Hardcastle, 'Achieving best value in private finance initiative project procurement' [2003] Construction Management and Economics, 461, 470. Y L Huang, S P Chou, 'Valuation of the minimum revenue guarantee and the option to abandon in BOT infrastructure projects' [2006] Construction Management and Economics, 379, 389.

${ }^{61}$ D Cumming, 'Government policy towards entrepreneurial finance, Innovation investment funds' [2007] Journal of Business Venturing, 193, 235.

${ }^{62}$ A J Edkins, H J Smith, 'Contractual management in PPP projects: evaluation of legal versus relational contracting for service delivery' [2006] Journal of Professional Issues in Engineering Education and Practice, 82, 93.

${ }^{63} \mathrm{~B}$ Li, A Akintoye, 'An overview of Public-Private Partnerships' in A Akintoye, M Beck, C Hardcastle (eds), Publicprivate partnerships: managing Risks and Opportunities, op. cit.. S P Ho, 'Model for Financial renegotiation in Publicprivate partnerships projects and its policy implications: game theoretic view' [2006] Journal of Construction Engineering and Management, 678, 688.
}

29 
Under this perspective, PPP cooperation arrangements present themselves as public service instruments. ${ }^{64}$ By choosing the PPP option, States choose to externalise the provision of a public service and the PPP inherent risk-transfer mechanism allows them to act differently in the public sector's management, as enablers and facilitator agents. At the same time, the vital role of the private sector in the funding and provision of infrastructure or service - through its input in the different project's phases - requires a continuous relationship between the private and public actors. The use of PPPs as public service instruments affects also the legal configuration of risks' allocation between the public and the private parties. Different kinds of risks need, in fact, to be adequately considered and distributed:

(i) the construction or project's risk, which is related to designing and building's costs overruns and/or to the project's delays;

(ii) the financial risk that arises from the inconstancy of interest rates, exchange rates or other factors that distress financing costs;

(iii) the performance risk, meaning the availability of an asset or the stability and quality of a certain service provided;

(iv) the demand risk that refers to the on-going needs of the service provision and of end-users; and

(v) the remaining risk value, which is related to the future market price of an asset or service provision.

Moreover, PPPs are conceived as investment instruments for the provision of public infrastructure and/or services. The funding schemes of projects delivered through PPPs can take different forms. It can be used as a stand-alone arrangement which means that the collected funding is intended specifically for the PPP project. Otherwise, a SPV may be used as a borrowing entity. ${ }^{65}$ Thus, an independent legal subject is specifically established to collect and manage the necessary funds to carry out the project. Or else, it can use a high ratio of debt by means of gearing or leverage. In this case, the project company normally has the minimum equity necessary to issue debt at an adequate cost. Moreover, a funding scheme could entail private lending, which normally depends on the project's specific cash flow and not on corporate balance sheets. Furthermore, there may be different kinds of financial guarantees - generally limited to equity contributions - given to lenders by the private sector involved in the PPP. The public actor normally does not provide for financial guarantees. The latter allow lenders to receive their repayment from the project's income or directly from the public actor. ${ }^{66}$

Finally yet importantly, PPPs are - even if so far not sufficiently - considered as growth instruments. At international level, the UN announced its commitment to fill in the gap between the poorest countries and the industrialised ones by agreeing on the UN Millennium Declaration according to which its members are devoted to a new global partnership. ${ }^{67}$ Remarkably, the stress

\footnotetext{
${ }^{64} \mathrm{C} \mathrm{H}$ Bovis, 'Efficiency and Effectiveness in Public Sector Management: the Regulation of Public Markets and Public-Private Partnerships and its Impact on Contemporary Theories of Public Administration' [2013] EPPPL, 186, 199.

${ }^{65}$ In Europe, this is the case for IPPPs.

${ }^{66}$ Financial guarantees can cover the failure of the public partner to meet its obligations under a PPP.

${ }^{67}$ Please refer to the latest report on The Millennium Development Goals, 2015, available at http://www.un.org/millenniumgoals/2015_MDG_Report/pdf/MDG\%202015\%20rev\%20(July\%201).pdf. 30
} 
has been put on the potential of PPPs in attaining the United Nations Millennium Development Goals. ${ }^{68}$ At the European level, there is an emblematic initiative for growth, the so-called 2020 Growth Strategy ${ }^{69}$ that motivated the European Council to approve several measures aiming at increasing investment, for instance, in the infrastructure of the Trans-European Transport Networks (TENs), ${ }^{70}$ as well as in research, innovation, development and delivery of services of general economic interest. ${ }^{71}$ In this respect, the PPP phenomenon is about providing incentives and attracting resources in an environment which naturally does not call for them, but that without them would not be capable of delivering goods or services. Under this perspective, it is believed that including a private interest in a public context, and/or vice versa, can be an effective way to create better opportunities, carry out and facilitate effective, innovative and sustainable projects.

\section{Public-Private Partnerships' Legal Background.}

\subsection{International Level: best practices.}

At supra-national level, the PPPs' legal background mainly consists of best practices. The term best practices refers to a set of guidelines, techniques, methodologies, ethics or ideas that, through experience and research, have proven to be the most efficient or the prudent course of action in order to achieve a desired result. A commitment to use best practices in any field is a commitment to use all the knowledge and technology at one's disposal to ensure the success of a certain asset. Best practices are normally laid down by international and/or non-governmental organizations and can be defined as soft law, non or quasi-legal instruments. This because they do not have legally binding force.

Best practices in the field of PPPs' arose with the spread of globalisation. Internationally active organisations ${ }^{72}$ were looking for a uniform set of standards of construction, business and management practice, especially for large investment projects, independent of countries and governments. Clearly defined, well-known and globally agreed upon best practices can recognise standards capable of reducing project's costs developing a predictable legal and business environment for the global construction and business industry. Thus, the creation of best practices in the PPPs' context emerged with the need of relying on international business standards, commercial relationships and professional communities with the additional aim of spreading ideas, networking, gathering and exchanging valuable contacts. It is within this picture that international

\footnotetext{
${ }^{68}$ The eight Millennium Development Goals - which range from fighting extreme poverty to blocking the spread of HIV and globally provide primary education - form a plan agreed by all the world's countries and world's leading development institutions. As already mentioned, world leaders gathered on September 25, 2015, at the United Nations in New York to adopt the 2030 Agenda for Sustainable Development agreed upon by 193 countries. The 2030 Agenda set out 17 new Sustainable Development Goals or Global Goals, which will guide policy and funding for the next 15 years. The objective was to lay down a set of universally applicable goals that balanced the three dimensions of sustainable development: environmental, social, and economic. The Global Goals replace the Millennium Development Goals.

${ }^{69}$ Communication from the Commission, Europe 2020, A strategy for smart, sustainable and inclusive growth, European Commission, Brussels, 3.3.2010, COM (2010) 2020 final, 21.

${ }^{70}$ Details available at http://ec.europa.eu/transport/themes/infrastructure/index_en.htm.

${ }^{71}$ C H Bovis, 'Efficiency and Effectiveness in Public Sector Management: the Regulation of Public Markets and Public-Private Partnerships and its Impact on Contemporary Theories of Public Administration' [2013] EPPPL, 186, 199.

${ }^{72}$ It is noteworthy to highlight that such organizations are mainly Multilateral Development Banks. For instance, The World Bank, European Bank for Reconstruction and Development, the Inter-American Development Bank, the African Development Bank, the Islamic Development Bank.
} 
organizations began to lay down guidebooks, ${ }^{73}$ guidelines ${ }^{74}$ and standardised contracts ${ }^{75}$ in order to improve the awareness, capacity and skills of the public and private sectors in the development of successful PPP projects.

With regard to best practices models, it is worthwhile mentioning that the United Nations Commission on International Trade law (hereinafter UNICITRAL) adopted the UNICITRAL Legislative Guide to Privately Financed Infrastructure Projects ${ }^{76}$ in 2001 and the UNICITRAL Model Legislative Provisions on Privately Financed Infrastructure Projects ${ }^{77}$ in 2003. At an international level, these documents provide an important legal reference framework when engaging in PPP projects. The Legislative Guide to Privately Financed Infrastructure Projects includes seventy-one recommended legislative principles that aim at supporting the creation of a PPP legislative framework. Explanatory notes, including an analytical description of the financial, regulatory, general legal and policy issues relevant to the PPP field, follow these recommendations. The Guide aims at providing reliable data in order to support the drafting of national PPP laws and regulations. Two years later, the Model Legislative Provisions on Privately Financed Infrastructure Projects rewrote the advice of the Legislative Guide to Privately Financed Infrastructure Projects in legislative terms laying down fifty-one provisions. The Legislative Guide to Privately Financed Infrastructure Projects and the Model Legislative Provisions on Privately Financed Infrastructure Projects highly affected the drafting of following best practices elaborated by international organizations: the Bank for Reconstruction and Development's Core Principles of $2006^{78}$ and the Recommendation of the Council on Principles for Public Governance of Public-Private Partnerships of 2012. ${ }^{79}$

Moreover, PPP-related educational and training materials, conferences and workshops were prepared. ${ }^{80}$ In addition, networks and centres of excellence in the PPP field began to be established in order to implement work programmes on PPPs. ${ }^{81}$ Expert Centres were set up all around the world to identify excellence, elaborate best practices' guides and assist governments in building their capabilities to develop successful PPP schemes. Expert Centres' main tasks normally include the conducting of research within a certain PPP sector, the dissemination of PPPs' best practices in that sector, the development of sector specific capability and growth strategies for governments and the

\footnotetext{
${ }^{73}$ For instance, the Guidebook on Public-Private Partnership in Infrastructure, Economic and Social Commission for Asia and the Pacific, 2011, available at http://www.unescap.org/sites/default/files/ppp_guidebook.pdf.

74 See, for instance, the PPPIRC, World Bank guidelines available at http://ppp.worldbank.org/public-privatepartnership/overview/practical-tools/procurement-bidding/standardized-guidelines. The PPPIRC provides sample PPP agreements and concessions, checklists and sample clauses, terms of reference, risk matrices, standard bidding documents developed by government agencies and sample PPP and sector legislation and regulation. These were designed for government officials, project managers and lawyers involved in PPP projects in developing countries. They provide international experience and precedents to help the development of well-functioning PPPs.

${ }^{75}$ As in the case of FIDIC which laid down the most common form of model contracts used in large construction projects. FIDIC is the International Federation of Consulting Engineers. Its members are national associations of consulting engineers.

${ }_{76}^{76}$ Available at https://www.uncitral.org/pdf/english/texts/procurem/pfip/guide/pfip-e.pdf.

${ }_{77}$ Available at https://www.uncitral.org/pdf/english/texts/procurem/pfip/model/03-90621_Ebook.pdf.

${ }_{78}^{78}$ Available at http://www.ebrd.com/downloads/legal/concessions/coreprin.pdf.

${ }^{79}$ Available at http://www.oecd.org/governance/budgeting/PPP-Recommendation.pdf.

${ }^{80}$ For instance, refer to the United Nations Economic Commission for Europe, Guidebook on Promoting Good Governance in Public-Private Partnerships, New York and Geneva, 2008, available at https://www.unece.org/fileadmin/DAM/ceci/publications/ppp.pdf.

81 As a way of example, the Committee on Innovation, Competitiveness and Public-Private Partnerships may be mentioned. It was specifically established in order to promote a policy, financial and regulatory environment leading to economic growth, innovative development and higher competitiveness, focusing mainly on countries with economies in transition. More details are available at http://www.unece.org/eci.html.
} 
provision of specialised training on PPP schemes. In fulfilling these tasks, a large number of expert Centres are supported by a coordinating hub at the United Nations Economic Commission for Europe Secretariat. ${ }^{82}$ The latter provides assistance in some of the most important PPP sectors. Furthermore, it established an International PPP Centre of Excellence in order to support governments in the structuring of effective PPPs, addressing many of the most demanding problems. ${ }^{83}$ These embrace the issue of greening the economy and the effects of climate change. Moreover, the aim of this Centre is to discover which PPP scheme constitutes an effective model and have the most beneficial impact on development. Along the same lines, the European Investment Bank, the European Commission, EU Member States and candidate countries created the European PPP Expertise Centre. ${ }^{84}$ The main objective of this Centre is again to enhance the public sector's skills when involved in PPP arrangements, thereby allowing EU Member States' PPP taskforces to share the knowledge gained in the PPPs' field. Remarkably, the Centre has recently published an interesting work entitled The Guide to Guidance. ${ }^{85}$ This guide highlights the best worldwide available guidelines on the implementation of PPP arrangements and seeks to support the public sector in the use of PPPs by easing the understanding of the related key issues and procedures involved in procurement goods and/or services through PPPs.

\subsection{European Level.}

\subsubsection{The absence of a uniform regulation: PPPs governed by the Treaty principles and EU public contracts and concessions law.}

At a European level, there is no uniform regulation of PPPs. However, this does not mean that there are no general principles capable of integrating the regulation of each legal category falling within the notion of PPPs. There are the Treaty principles, ${ }^{86}$ which form - at European level - the first and main regulating legal framework of the PPP phenomenon. ${ }^{87}$ Even if of a general nature, the Treaty principles govern PPPs by adapting themselves to their distinctive features. They are, in fact, fundamental values and criteria that characterize and integrate a still missing uniform PPP regulation.

The same EU Institutions that highlighted the absence of a uniform regulation of PPPs indicated, as a logical consequence, that the PPP phenomenon, and in particular each legal category falling within the PPP notion, is subject to EU law. ${ }^{88} \mathrm{EU}$ Institutions specifically recalled the fundamental criterion under which any act, unilateral or bilateral, ${ }^{89}$ through which a contracting authority 'entrusts the provision of an economic activity to a third party must be examined in the

\footnotetext{
${ }^{82}$ UNECE stands for United Nations Economic Commission for Europe. The latter created a Secretariat aimed at supporting national expert centres. Further details are available at http://www.unece.org/index.php?id=32394.

${ }^{83}$ Further data is available at

http://www.unece.org/ceci-welcome/areas-of-work/public-private-partnerships-ppp/icoeppp.html.

${ }^{84}$ Further details are available at http://www.eib.org/epec/.

${ }^{85}$ The Guide is of 2011 and it is available at http://www.eib.org/epec/resources/guide-to-guidance-en.pdf.

${ }^{86}$ Reference is made to the EC Treaty. Footnotes will indicate the respective TFEU provisions.

${ }^{87}$ Specifically, the principles of freedom of establishment and of service provision and, more generally, all those ensuring the principle of free competition. See the Green Paper on Public-Private Partnerships and Community law on Public Contracts and Concessions, COM (2004) 327 final, point 8. See also below Chapter II, paragraph 4.2.2..

${ }^{88}$ See below Chapter II, par. 4.2.1..

${ }^{89}$ See note 52 of the Green Paper on Public-Private Partnerships and Community law on Public Contracts and Concessions, COM (2004) 327 final. 
light of the rules and principles resulting from the Treaty. ${ }^{90}$ This criterion defines the applicability of EU law and - with regard to PPPs - represents the first and general relevant applicable principle. Thus, whenever a legal category falls within the PPP genus and implies entrusting to a private operator an economic activity, the Treaty principles and provisions do apply.

EU Institutions also specified that 'under Community law, public authorities are free to pursue economic activities themselves or to assign them to third parties, such as mixed capital entities founded in the context of a PPP. However, if public bodies decide to involve third parties in economic activities and if this involvement qualifies as a public contract or a concession, the Community provisions for public procurement and concessions must be complied with. ${ }^{91}$ Reference is made to what is usually called EU public contracts and concessions law, which consists of the principles of the Treaty, and in certain cases, of the provisions of the Directives on the coordination of awarding procedures. ${ }^{92}$ In this regard, it was highlighted that - by recalling the CJEU case law on in-house providing ${ }^{93}$ - 'the fact that a private party and a contracting entity cooperate within a public-private entity, cannot serve as justification for the contracting entity not having to comply with the legal provisions on public contracts and concessions.' 94

Before delving into each Treaty principle relevant in the field of public-private collaborations, it is worthwhile mentioning the existence of a particular cross-reference relationship between the principles and the provisions of the Treaty and between each principle. The following extracts show how this cross-reference relationship works. The chosen extracts come from the Commission's Interpretative Communication on the Application of Community Law on Public Procurement and Concessions to Institutionalised PPP, ${ }^{95}$ the Green Paper $^{96}$ and the CJEU judgement in Sea S.r.l. v Comune di Ponte Nossa. ${ }^{97}$ They state that:

A. 'in the field of public procurement and concessions, the principle of equal treatment and the specific expressions of that principle, namely the prohibition of discrimination on the grounds of nationality and Articles 43 EC on freedom of establishment and 49 EC on freedom to provide services, are to be applied in cases where a public authority entrusts the supply of economic activities to a third party. More specifically, the principles arising from Article 43 EC and Article 49 EC include not only non-discrimination

\footnotetext{
${ }^{90}$ See point 8 and note 7 of the Green Paper on Public-Private Partnerships and Community law on Public Contracts and Concessions, COM (2004) 327 final.

${ }^{91}$ Par. 1 of the Commission Interpretative Communication on the application of Community law on Public Procurement and Concessions to Institutionalised Public-Private Partnerships (IPPP), Brussels, 05.02.2008, C (2007) 6661.

${ }^{92}$ See point 57 of the Green Paper on Public-Private Partnerships and Community law on Public Contracts and Concessions, COM (2004) 327 final. See also par. 2.1 of the Commission Interpretative Communication on the application of Community law on Public Procurement and Concessions to Institutionalised Public-Private Partnerships (IPPP), Brussels, 05.02.2008, C (2007) 6661.

${ }^{93}$ Para 49, C-26/03, Stadt Halle, ECR [2005], I-1. Paragraphs 30 et ss., C-410/04, ANAV, ECR [2006], I-3303.

${ }^{94}$ Par. 2.1 of the Commission Interpretative Communication on the application of Community law on Public Procurement and Concessions to Institutionalised Public-Private Partnerships (IPPP), Brussels, 05.02.2008, C (2007) 6661.

${ }^{95}$ Ibid.

${ }^{96}$ Green Paper on Public-Private Partnerships and Community law on Public Contracts and Concessions, COM (2004) 327 final.

${ }^{97}$ Points 37 and 40, C-573/07, Sea Srl v Comune di Ponte Nossa, 2009 I-08127. 
and equality of treatment, but also transparency, mutual recognition and proportionality. ${ }^{98}$

B. 'the provisions on freedom of establishment require compliance with the principles of transparency and equality of treatment 99

C. 'That case-law is relevant for the interpretation of both Directive 2004/18 and Articles 12 EC, 43 EC, and 49 EC, and also of the general principles of which the latter are the specific expression. ${ }^{100}$

Extracts A. and B. show that Articles 18, 49 and 56 of the TFEU are 'specific expressions' of one (equal treatment, extract A) or more principles (extract C), but at the same time that they 'include' (extract A) - in the sense that they appear to be sources of - other principles (e.g. principles of transparency, mutual recognition and proportionality). Thus, the relationship between the Treaty principles and provisions can be defined as bi-directional, meaning from the principles to the provisions and from the provisions to the principles. ${ }^{101}$ With regard to the relationship between principles, in extract A., the principle of freedom of establishment is considered as a 'specific expression' of the principle of equal treatment. In extract B., the provisions on freedom of establishment impose the respect of the principle of equal treatment. Hence, also the relationship between principles could be conceived as bi-directional, meaning from the principle $a$ to the principle $b$, and from the latter to the former. The mentioned bi-directionality shows the tight connection between all the elements forming the general legal framework of the PPP category. Both if the principles are expressively mentioned in the Treaty or if they are implicitly inferable from - as a pre-requisite or a result of - its provisions.

\subsubsection{The Treaty principles.}

This paragraph provides an overview of the relevant Treaty principles in the field of PPPs. ${ }^{102}$ First of all, the principle of free competition has to be mentioned (Articles 101 et ss. TFEU). In public contracts and concessions law, this principle implies that the awarding - in the case of PPPs, the selection of the private partner - must be carried out through a competitive procedure. According to the CJEU case law, specific provisions and other principles of the Treaty safeguard this principle. For instance, 'it follows from Article 106, para 1, TFEU, that Member States must not maintain in force national legislation which permits the award of public service concessions without their being

\footnotetext{
${ }^{98}$ Paragraph 2.1 of the Commission interpretative communication on the application of Community law on Public Procurement and Concessions to institutionalised PPP (IPPP) (2008/C 91/02).

${ }^{99}$ Point 68 of the Green paper on public-private partnerships and community law on public contracts and concessions, Brussels, 30.4.2004 COM (2004) 327 final.

${ }^{100}$ Point 37, C-573/07, C-573/07, Sea Srl v Comune di Ponte Nossa, [2009] I-08127.

${ }^{101}$ In this respect, see G Sciullo, 'Le dinamiche collaborative tra pubblico e privato ed i principi generali di riferimento' in F Mastragostino (ed), La collaborazione pubblico-privato e l'ordinamento amministrativo, Dinamiche e modelli di partenariato in base alle recenti riforme (Giappichelli, 2011) 28.

${ }^{102}$ In this respect, among others, C H Bovis, EU public procurement law (Edward Elgar, 2007). R Caranta, 'The Borders of EU Public Procurement Law' in R Caranta, D Dragos (eds), Outside the EU Procurement Directives - Inside the Treaty? (DJØF, 2012) 25 et ss.. Sue Arrowsmith, The Law of Public and Utilities Procurement: Regulation in the EU and UK, op. cit.. C Risvig Hamer, Contracts not covered or not fully covered by the Public Sector Directive (DJØF, 2012). - A Semple, A Practical Guide to Public Procurement, (Oxford University Press, 2015) 35 et ss..
} 
put out to competition, since such an award infringes Articles 49 and 56 TFEU or the principles of equal treatment, non-discrimination and transparency. ${ }^{103}$ The logical primacy of the principle of free competition that arises out this statement ends up giving relevance to the meaning and implication of other principles.

Among the latter, there are the principles of equal treatment and of non-discrimination upon nationality (Articles 18, but also 49 and $56^{104}$ TFEU). These principles are often mentioned together in the CJEU's case law ${ }^{105}$ and secondary EU law. ${ }^{106}$ Sometimes they are considered as interchangeable notions, ${ }^{107}$ at other times - and in certain fields - they are distinctively considered, but still linked to each other. For instance, in the context of public procurement, the principle of non-discrimination is mentioned with regard to the formulation of award criteria. Instead, the principle of equal treatment is referred to when explaining the application of the said award criteria. ${ }^{108}$ The principle of non-discrimination presents itself as a specific expression of the principle of equality (in the sense of prohibition of different treatment for identical situations and identical treatment of different situations). ${ }^{109}$ Therefore, there is the possibility of a wider application of the principle of equal treatment with respect to the principle of non-discrimination (e.g. equality of treatment of operators also of the same nationality). ${ }^{110}$ Anyway, these principles are both characterised by the aim of guaranteeing 'competition within the internal market' (Article 101, TFEU). From the CJEU application of the principle of equal treatment in the field of public contracts (in particular when stating the need to have offers that comply with tender conditions in order to allow a comparison between them ${ }^{111}$ ) it is possible to state that - along the same lines as that held by the Commission with regard to concessions in EU law ${ }^{112}$ - in the field of PPPs the principle of equal treatment requires that the selection of the private partner must be carried out in compliance with the procedural rules and requirements initially established. ${ }^{113}$ In any case, the selection must be carried out upon objective criteria. Moreover, the potential technical improvements proposed by tenderers - based on the solutions originally foreseen by the contracting authority - cannot concern the essential elements of the project. If, initially, the public sector did not

\footnotetext{
${ }^{103}$ Point 50, C C-196/08, Acoset SpA v Conferenza Sindaci e Presidenza Prov. Reg. ATO Idrico Ragusa and Others, [2009] I-09913. Point 23, C-410/04, ANAV v Comune di Bari and AMTAB Servizio SpA, [2006] I-03303. Points 51 et ss., C-458/03, Parking Brixen GmbH v Gemeinde Brixen and Stadtwerke Brixen AG, [2005] I-08585.

${ }_{104}$ Articles 49 and 56 are considered by the CJEU expression of the principle of equal treatment. In this regard, see C330/91, The Queen v Inland Revenue Commissioners, ex parte Commerzbank AG, [1993] I-04017.

${ }^{105}$ For instance, see point 32, C-454/06, Pressetext Nachrichtenagentur GmbH v Republik Österreich (Bund), [2008] I04401. Point 39, C-573/07, Sea Srl v Comune di Ponte Nossa, [2009] I-08127.

${ }^{106}$ For instance, Article 2 of Directive 2004/18/EC of the European parliament and of the council of 31 March 2004 on the coordination of procedures for the award of public works contracts, public supply contracts and public service contracts.

${ }^{107}$ See, by way of example, C-422/02 P, Europe Chemi-Con (Deutschland) GmbH v Council of the European Union, [2005] I-00791, where the principle of equal treatment is also called of non-discrimination.

${ }^{108}$ In this regard see A Massera, 'I Principi Generali' in M P Chiti, G Corso (eds), Trattato di Diritto Amministrativo Europeo (Giuffrè, 2007) 339.

${ }^{109}$ Point 16, C-810/79, Peter Überschär v Bundesversicherungsanstalt für Angestellte, [1980] I-02747. See also A Massera, 'I Principi Generali' op. cit., 341.

${ }^{110}$ Point 20, C-410/04, ANAV v Comune di Bari and AMTAB Servizio SpA, [2006] I-03303. Point 48, C-196/08, Acoset SpA v Conferenza Sindaci e Presidenza Prov. Reg. ATO Idrico Ragusa and Others, [2009] I-09913.

${ }_{111}$ Point 37, C-243/89, Commission of the European Communities v Kingdom of Denmark, [1993] I-03353.

112 Commission Interpretative Communication on Concessions under Community Law (2000/C 121/02) para 3.1.1.. This Communication is explicitly referred to by the Commission Interpretative Communication on the application of Community law on Public Procurement and Concessions to Institutionalised Public-Private Partnerships (IPPP), Brussels, 05.02.2008, C (2007) 6661, para 2.1, note 10.

${ }^{113}$ See below paragraph 4.2.4.1. on public contracts' award procedures and relevant 2014 innovations. 
specifically define its technical needs, any tenderer must have the possibility to propose different technical solutions. ${ }^{114}$

Furthermore, the principles of transparency ${ }^{115}$ and publicity ${ }^{116}$ derive from the principles of equal treatment and of non-discrimination. The relationship between these two principles is structured upon logical implications: the 'obligation of transparency [...] consists in ensuring, for the benefit of any potential tenderer, a degree of advertising sufficient to enable the services market to be opened up to competition and the impartiality of procurement procedures to be reviewed.' 117 A specific application of the principle of transparency concerns tender documents. For instance, in the context of IPPPs, the principle of transparency entails the clear indication of the optional renewals or modifications of the public contract or concession initially awarded to an entity publicly and privately held. ${ }^{118}$

Other relevant principles in the field of PPPs are the principles of mutual recognition and proportionality. ${ }^{119}$ The former principle ${ }^{120}$ applies with regard to the free movement of goods, people and services and, in general terms, expresses Member States' obligation to allow goods and services, legally produced and marketed in other Member States, to circulate and be placed on their markets. ${ }^{121}$ In the field of PPPs, the principle of mutual recognition requires Member States to consider meeting the requirements (e.g. technical specifications, titles, qualifications) that they expect from the potential private partner, to the extent that such requirements are recognized as equivalent according to the law of the country of origin of the concerned operator. ${ }^{122}$ The principle of proportionality requires that public authorities' actions, such as the imposition of obligations or restrictions on a bidder's freedom, have to be adequate and necessary in relation to the public interest's objectives pursued. ${ }^{123}$ In the PPP context, the principle of proportionality prohibits contracting authorities from requiring - during the private partner selection - technical, professional

\footnotetext{
${ }^{114}$ Commission Interpretative Communication on Concessions under Community Law (2000/C 121/02 para 3.1.1..

115 Para 2.3.5. of the Commission Interpretative Communication on the application of Community law on Public Procurement and Concessions to Institutionalised Public-Private Partnerships (IPPP), Brussels, 05.02.2008, C (2007) 6661. See also point 49, C-458/03, Parking Brixen GmbH v Gemeinde Brixen and Stadtwerke Brixen AG, [2005] I08585.
}

116 Point 39, C-573/07, Sea Srl v Comune di Ponte Nossa, [2009] I-08127. Point 32, C-454/06, Pressetext Nachrichtenagentur GmbH v Republik Österreich (Bund), [2008] I-04401. See also M P Chiti, 'I Principi' in M A Sandulli, R De Nictolis, R Garofoli (eds), Trattato sui contratti pubblici (Giuffrè, 2008) 164.

${ }^{117}$ Point 62, C-324/98, Telaustria Verlags GmbH and Telefonadress GmbH v Telekom Austria AG, [2000] I-10745. See also point 21, C-410/04, ANAV v Comune di Bari and AMTAB Servizio SpA, [2006] I-03303. Point 49, C-196/08, Acoset SpA v Conferenza Sindaci e Presidenza Prov. Reg. ATO Idrico Ragusa and Others, [2009] I-09913. The said statement comes from point 29 of the Green Paper on Public-Private Partnerships and Community law on Public Contracts and Concessions, COM (2004) 327 final. Point 49, C-458/03, Parking Brixen GmbH v Gemeinde Brixen and Stadtwerke Brixen AG, [2005] I-08585.

${ }^{118}$ Para 2.3.5 of the Commission Interpretative Communication on the application of Community law on Public Procurement and Concessions to Institutionalised Public-Private Partnerships (IPPP), Brussels, 05.02.2008, C (2007) 6661.

${ }^{119}$ Para 3.1.4 of the Commission Interpretative Communication on Concessions under Community Law (2000/C 121/02).

${ }^{120}$ For an analysis on the principle, see G Tesauro, Diritto dell'Unione Europea, (6th ed, Cedam, 2010) 438 et ss..

121 The principle of free movement of goods was stated by the CJEU in C-120/78, Rewe-Zentral AG $v$ Bundesmonopolverwaltung für Branntwein, [1979] 00649. The principle of freedom of establishment was stated in C340/89, Irène Vlassopoulou v Ministerium für Justiz, Bundes- und Europaangelegenheiten Baden-Württemberg, [1991] I-02357. The principle of free movement of services was stated in C-76/90, Manfred Säger v Dennemeyer \& Co. Ltd., [1991] I-04221.

${ }^{122}$ Commission Interpretative Communication on Concessions under Community Law (2000/C 121/02) para 3.1.4..

${ }^{123}$ M P Chiti, 'I Principi' in M A Sandulli, R De Nictolis, R Garofoli (eds), Trattato sui contratti pubblici (Giuffrè, 2008) 163. 
or financial skills not proportionate to the object of the partnership. At the same time, whenever a PPP leads to a long lasting relationship, the principle of proportionality requires that its duration does not restrict or distort competition more than what is needed in order to allow the identified private operator to recover its investments and obtain a reasonable remuneration. ${ }^{124}$

An effective synthesis of how the Treaty principles generally work can be found in the following extract. 'The rules resulting from the relevant provisions of the Treaty can be summed up in the following obligations: fixing of the rules applicable to the selection of the private partner, adequate advertising of the intention to award a concession and of the rules governing the selection in order to be able to monitor impartiality throughout the procedure, introduction of genuine competition between operators with a potential interest and/or who can guarantee completion of the tasks in question, compliance with the principle of equality of treatment of all participants throughout the procedure, selection on the basis of objective, non-discriminatory criteria., 125

To conclude, it can be recalled a general reference criterion pertaining, not to the PPP category as a whole, but to only one of its types, the IPPP. It is a concrete application of the fundamental principle of free competition and it is understood - in PPP terms - as a principle of competitive procedure. It is the principle related to the need to avoid a double tender. It offers an answer to the issue of whether or not it is necessary to carry out a tender procedure for the award of a public contract or concession to a jointly held company, when the contracting authority has already selected the private partner through a competitive procedure. The Commission Interpretative Communication on IPPPs provided a practical solution to the issue by stating that there has to be one unique competitive procedure with two objectives. On the one hand, the public contract or concession to award and, on the other hand, the private partner's operational contribution to the project in relation to the performance of the tasks of the jointly held company, or even just its contribution to the management of the entity. ${ }^{126}$ The Advocate General's conclusion in the Acoset case - sharing the Commission's view - showed that the choice of the private partner is carried out 'indirectly through the selection of the industrial participant." ${ }^{127}$ The CJEU set out a clear point on the issue by stating that if a 'private participant [...] is selected by means of a public and open procedure after verification of the financial, technical, operational and management requirements specific to the service to be performed and of the characteristics of the tender with regard to the service to be delivered, provided that the tendering procedure in question is consistent with the principles of free competition, transparency and equal treatment laid down by the Treaty with regard to concessions,' EU law ${ }^{128}$ 'does not preclude the direct award' of a public service to a jointly held company specifically established 'for the purpose of providing that service and possessing a single corporate purpose. ${ }^{129}$ The central point of the CJEU reasoning is the following. If the selection criteria refer not only to its capital contribution, but also to its technical skills and to

\footnotetext{
${ }^{124}$ In this regard see for instance, para 3.1.3 of the Commission Interpretative Communication on Concessions under Community Law (2000/C 121/02).

125 Point 30 of the Green Paper on Public-Private Partnerships and Community Law on Public Contracts and Concessions, Brussels, 30.4.2004 COM (2004) 327 final.

${ }^{126}$ Para 2.2 of the Commission Interpretative Communication on the application of Community law on Public Procurement and Concessions to Institutionalised Public-Private Partnerships (IPPP), Brussels, 05.02.2008, C (2007) 6661.

${ }^{127}$ Point 89 of the Opinion of the Advocate General Ruiz-Jarabo Colomer delivered on June 2, 2009 1(1) in C-196/08, Acoset SpA v Conferenza Sindaci e Presidenza Prov. Reg. ATO Idrico Ragusa and Others, [2009] I-09913.

${ }^{128}$ Specifically, Articles 49, 56 and 106 TFEU.

${ }^{129}$ Point 63, C-196/08, Acoset SpA v Conferenza Sindaci e Presidenza Prov. Reg. ATO Idrico Ragusa and Others, [2009] I-09913.
} 
the characteristics of its tender - and the private operator is entrusted with the operation of the service in question - 'the selection of the concessionaire can be regarded as an indirect result of the selection of that participant. ${ }^{130}$ Therefore, it is the application of the principle of free competition referred to the private party's selection - that allows a direct awarding of a service to a jointly held company. Thus, whenever the object of a public and open procedure covers also the private operator's characteristics - as it is the party to whom the operational activity of the jointly held company is entrusted - the choice of the partner also logically and legally implies the choice of the mixed entity to which the operational activity is formally awarded.

\subsubsection{EU Soft Law: Interpretative Communications, Resolutions and Green Papers.}

EU soft law builds on the assumption that there is no uniform regulation of the PPP phenomenon. Specifically, the Commission's 2004 Green Paper ${ }^{131}$ indicates that 'Community law does not lay down any special rules covering the PPP category'. ${ }^{132}$ Moreover, the Commission in its Communication of 2005 acknowledged that the consultations following the 2004 Green Paper showed 'stakeholder opposition to a regulatory regime covering all contractual PPPs.' In addition, and consequently, the Commission stated that it did 'not envisage making them subject to identical award arrangements. ${ }^{133}$ Then, the European Parliament in its 2006 Resolution held that it opposed 'the creation of a separate legal regime for PPPs.' ${ }^{134}$ Eventually, the Commission, in its Interpretative Communication of 2008 reaffirmed that 'at Community level there are no specific rules governing the founding of IPPP., 135

Notwithstanding the above, the legal background of PPPs was defined and developed by, inter alia, an intense elaboration undertaken by the European Commission. The latter, in fact, enacted a large number of non-binding legal instruments in the field of PPPs. ${ }^{136}$ Pursuant to the Commission's view, ${ }^{137}$ the PPP phenomenon should reflect each Member State's experience, acknowledging that the public sector has abandoned its intervening role and is now an actor,

\footnotetext{
${ }^{130}$ Point 60, C-196/08, Acoset SpA v Conferenza Sindaci e Presidenza Prov. Reg. ATO Idrico Ragusa and Others, [2009] I-09913.

${ }^{131}$ Green Paper on Public-Private Partnerships and Community law on Public Contracts and Concessions, COM (2004) 327 final.

${ }^{132}$ Point 8 of the Green Paper on Public-Private Partnerships and Community law on Public Contracts and Concessions, COM (2004) 327 final.

${ }^{133}$ Para 2.3.1. of the Communication from the Commission to the European parliament, the council, the European economic and social committee and the committee of the regions on Public-Private Partnerships and Community Law on Public Procurement and Concessions, Brussels, 15.11.2005 COM(2005) 569 final.

${ }^{134}$ Point 2 of the European Parliament Resolution on Public-Private Partnerships and Community law on Public Procurement and Concessions (2006/2043(INI)).

135 Para 2.1. of the Commission Interpretative Communication on the application of Community law on Public Procurement and Concessions to Institutionalised Public-Private Partnerships (IPPP), Brussels, 05.02.2008, C (2007) 6661.

${ }^{136}$ For instance, see Green Paper on Public-Private Partnerships and Community law on Public Contracts and Concessions, COM (2004) 327 final. Communication from the Commission to the European parliament, the council, the European economic and social committee and the committee of the regions on Public-Private Partnerships and Community Law on Public Procurement and Concessions, Brussels, 15.11.2005 COM (2005) 569 final. Commission Interpretative Communication on the application of Community law on Public Procurement and Concessions to Institutionalised Public-Private Partnerships (IPPP), Brussels, 05.02.2008, C (2007) 6661. Communication from the Commission to the European Parliament, the Council, the European Economic and Social Committee and the Committee of the Regions, 'Mobilizing private and public investment for recovery and long-term structural change: developing Public Private Partnerships', Brussels, 19.11.2009, COM (2009) 615 final.

${ }^{137}$ Initially laid down in the mentioned Green Paper on Public-Private Partnerships and Community law on Public Contracts and Concessions, COM (2004) 327 final.
} 
organizer and controller. The Commission held that the choice for a public-private cooperation scheme should be justified upon ascertained micro-economic advantages and that the peculiar contractual relationship between the public partner and the private operator should be structured in order not to elude public policies of financial restriction. ${ }^{138}$ Moreover, the Commission considered it important to preserve the differences between PPPs and other legal categories not falling within this notion. Furthermore, the Commission highlighted that, in case of IPPPs, critical aspects concern their compatibility with EU public contracts law - specifically with regard to selection criteria - the ways of entrustment of the relevant activity and the principles guiding its execution. ${ }^{139}$

As indicated above, these issues have been analysed by the same Commission in its Communication of 2008. ${ }^{140}$ In this document, the EU's executive body stated that the private actor has to participate to the activity carried out by the jointly held entity, not by merely providing funds, but by actively participating in the execution of the entity's functions or management. Moreover, the Commission held that the private partner must be selected through a procedure that focuses both on the contract and on the active participation of the private partner in the execution and management of the entity. Otherwise, a second tender procedure would be needed for the award of the concession.

Considering the current state of the art and, specifically, the numerous legal categories falling within the PPP category, the above-mentioned European Institutions' positions do not seem to be that questionable. What should instead be questioned is whether or not there is a need for a uniform EU regulation of PPPs. The Commission's negative answer was given because of (i) the specificities of each legal category falling within the broad notion of PPPs and (ii) the need to encourage the creation of new legal categories of PPPs, in accordance with the on-going socioeconomic developments. A different question is also whether certain legal categories falling within the PPP umbrella should or should not be regulated by specific EU law regulation. ${ }^{141}$

\subsubsection{EU Directives.}

The EU Directives in the field of public contracts do not provide for a specific regulation of PPPs. ${ }^{142}$ Nonetheless, PPP arrangements do fall within the scope of the EU public procurement Directives $^{143}$ as they represent a particular category of public contracts. ${ }^{144}$ In fact, and as it has been

\footnotetext{
${ }^{138}$ As recalled also in the Communication from the Commission to the European parliament, the council, the European economic and social committee and the committee of the regions on Public-Private Partnerships and Community Law on Public Procurement and Concessions, Brussels, 15.11.2005 COM (2005) 569 final.

${ }^{139}$ Points 53 et ss. of the Green Paper on Public-Private Partnerships and Community law on public contracts and concessions, COM (2004) 327 final.

${ }^{140}$ Commission Interpretative Communication on the application of Community law on Public Procurement and Concessions to Institutionalised Public-Private Partnerships (IPPP), Brussels, 05.02.2008, C (2007) 6661.

${ }^{141}$ As it happened with concession contracts that have been regulated by Directive 2014/23/EU of the European Parliament and of the Council of 26 February 2014 on the award of concession contracts. See below Chapter II, paragraph 4.2.4.2..

${ }^{142}$ See European Parliament Resolution on Public-Private Partnerships and Community law on Public Procurement and Concessions $(2006 / 2043$ (INI)) where it is stated that there is no intention to create a legal regime specific for PPPs (point 2 of the General Observations).

${ }^{143}$ Which today are the following. Directive 2014/24/EU of the European Parliament and of the Council of 26 February 2014 on public procurement and repealing Directive 2004/18/EC. Directive 2014/25/EU of the European Parliament and of the Council of 26 February 2014 on procurement by entities operating in the water, energy, transport and postal services sectors and repealing Directive 2004/17/EC. Directive 2014/23/EU of the European Parliament and of the Council of 26 February 2014 on the award of concession contracts. In this respect see, inter alia, M Burnett, 'The New 40
} 
mentioned before, public authorities can carry out economic activities on their own or assign them to third parties, including recurring to PPP schemes. Whenever they decide to include third parties in the provision of public services and/or infrastructure - and this inclusion takes the shape of either a public contract or a concession - then EU public contracts and concessions law applies. The latter guarantees to all interested economic operators the right to tender for public contracts and concessions in an equal and transparent way. In this way, reducing projects' costs through greater competition while, at the same time, promoting the functioning of the Internal Market.

Thus, PPPs fall within the scope of EU public procurement Directives. However, no Directive specifically regulates such a legal category. Hence, different rules apply according to the PPP scheme chosen and implemented. In the case of PPPs taking the form of concessions, there is a specific Directive dedicated to these legal options. On March 28, 2014, a new Directive, $2014 / 23 / \mathrm{EU},{ }^{145}$ on the award of concession contracts was published in the Official Journal of the European Union (hereinafter OJEU), as part of a legislative package reforming EU procurement rules. ${ }^{146}$ PPPs taking, instead, other legal forms have to be awarded according to the full EU public procurement regime. The identification and application of the right and/or adequate procedural procurement rule is, however, not always straightforward. This is because of the complexity of PPP projects, the long-term nature of these contracts, the length and related high costs of bidding and award procedures. In addition, in PPPs, consortia generally submit bids and private funding involves banks and funds in the procurement process. These elements increase the complexity of the whole arrangement and lead to a number of difficulties that may range from costs complaints to unexpected delays and legal uncertainties on how to carry out PPPs under EU public contracts rules. As of today, in the EU, many practical difficulties have been overcome through the day-to-day practice, the increased standardisation of contract-terms for certain PPPs models and a more harmonised approach to this kind of contracting. Nonetheless, the use of PPPs still remains quite complex, with a large potential for legal mistakes in terms of costs and delays.

Before 2004, the legal regime governing public contracts' awards - generally defined by EU public procurement Directives - was considered not adequate for PPPs. ${ }^{147}$ Specifically, it was believed that the traditional open and restricted procedures were not flexible enough, but also that as the European Commission held - the more flexible negotiated procedure with notice was not available for many PPP contracts. ${ }^{148}$ Hence, in 2004 a new procedure was created, the competitive dialogue procedure. The latter was introduced by the so-called public sector Directive ${ }^{149}$ which was the public contracts' fundamental Directive providing for a method of contract awarding. Today,

European Directive on the Award of Concession Contracts, Promoting Value for Money in PPP Contracts?' [2014] EPPPL, 86, 103.

${ }^{144}$ J Kitsos, 'Construction Investments in Public Works through Public Private Partnerships' [2014] EPPPL, 202, 208.

${ }^{145}$ The deadline for its transposition by EU Member States into national law was April 18, 2016.

${ }^{146}$ On the same day, Directives 2014/24/EU and 2014/25/EU, relating to procurement by public sector contracting authorities and utilities entities replacing the EU procurement directives of 2004, were also published.

${ }^{147}$ See for instance, S Arrowsmith, 'The European Procurement Rules and Public-Private Partnerships: EU Policies in Conflict?' [2000] CML Rev, 709. P Braun, 'Strict Compliance versus Commercial Reality: the Practical application of EC Public Procurement Law to the UK's Private Finance Initiative' [2003] ELJ 575. P Braun, 'Selection of Bidders and Contract Award Criteria: the Compatibility of Practice in PFI Procurement with European Law' [2001] PPLR 1.

${ }^{148}$ See, among others, S Arrowsmith, The Law of Public and Utilities Procurement, Regulation in the EU and UK (Sweet \& Maxwell, 2014).

${ }^{149}$ Directive 2004/18/EC of the European Parliament and of the Council of 31 March 2004 on the coordination of procedures for the award of public works contracts, public supply contracts and public service contracts, Official Journal L 134, 30/04/2004, 0114, 0240.

41 
the 2014 Directive on public procurement repealed the 2004 public sector Directive. ${ }^{150}$ The exact content and relevance of this Directive for PPPs will be now discussed.

\subsubsection{Public contracts' award procedures and relevant 2014 changes: general overview.}

The use of specific procedures for the award of public contracts characterizes the procurement regulated under the EU Directives. ${ }^{151}$ Coordination of procedures under the Directives aims at harmonizing the different national and organizational practices. The 2014 reform of the public procurement legislative regime introduced two new procedures ${ }^{152}$ and a certain number of changes to the five existing ones. ${ }^{153}$ The declared intention was to streamline procedures and provide greater flexibility for both contracting authorities and economic operators. ${ }^{154}$ For PPP contracts, both objectives are potentially beneficial. On the one hand, smoother procedures may counteract the complexity of PPP contracts encouraging the awarding of such arrangements. On the other hand, a higher degree of flexibility throughout the process may allow the award of better functioning PPP contracts. This paragraph will provide an overview of the reformed public contracts' award procedures ${ }^{155}$ with a highlight on their relevance and suitability for PPP contracts' awards.

Following the 2014 reform, contracting authorities may resort to any of the procurement procedures indicated in the Table below, provided that the conditions for their application are met. The choice of the most adequate procedure is a central and strategic question for the public sector.

\footnotetext{
${ }^{150}$ Directive 2014/24/EU of the European Parliament of the Council of 26 February 2014 on Public Procurement and repealing Directive 2004/18/EC Text with EEA relevance [2014] OJ L 94 (Directive 2014/24/EU). On December 2011 the European Commission published proposals to revise and update the public sector and utilities Directives (2004/18/EC and 2004/17/EC respectively) along with a proposed new directive on the award of concession contracts. Following negotiations between Member States, three new texts were agreed upon and came into force on April 2014. Member States had to transpose them into their national legal systems within 24 months from that date. The new EU rules provide for a more modern, flexible and commercial approach compared to the previous regime. New aspects have been introduced to consolidate and modernize public procurement. Contracting authorities should be now able to run procurement procedures faster, with more focus on getting the right supplier and best tender. For suppliers, the tender process should be quicker, less costly, and less bureaucratic, allowing them to compete more effectively.

${ }^{151}$ Directive 2014/24/EU of the European Parliament and of the Council of 26 February 2014 on public procurement and repealing Directive 2004/18/EC. Directive 2014/25/EU of the European Parliament and of the Council of 26 February 2014 on procurement by entities operating in the water, energy, transport and postal services sectors and repealing Directive 2004/17/EC. Directive 2014/23/EU of the European Parliament and of the Council of 26 February 2014 on the award of concession contracts.

${ }^{152}$ The competitive procedure with negotiation and the innovation partnership procedure.

${ }^{153}$ Namely, the open and restricted procedures, the competitive dialogue procedure, the negotiated procedure without prior publication and design contest.

${ }^{154}$ Under the 2014 Directives, for the first time, Member States had to transpose into their domestic legislation all procedures, with the exclusion of the negotiated procedure without prior publication.

${ }^{155}$ As set out in the 2014 Directives.
} 
Open

Restricted

Competitive procedure

with negotiation

Competitive dialogue

Innovation partnership

Negotiated procedure without prior publication

Design contest

$\begin{array}{cc}\text { None } & \text { None } \\ \text { None } & \text { None } \\ \text { Must justify } & \text { None } \\ \text { Must justify } & \text { None } \\ \text { None }^{\mathrm{i}} & \text { None } \\ \text { Exceptional } & \text { Exceptiona } \\ \text { None } & \text { None }\end{array}$

i There are no explicit restrictions on innovation partnerships. However, such a procedure can be used when contracting authorities' needs cannot be satisfied by solutions already present on the market (Article 31 of Directive 2014/24/EU, Article 49 of Directive 2014/25/EU).

As it will be seen, the new competitive procedure with negotiation and the competitive dialogue appear to be the most suitable procedures for the award of PPP contracts. In fact, the justification grounds for the use of such procedures - especially conditions (iii) and (iv) mentioned below normally arise frequently in the context of PPPs. Article 26, Directive 2014/24/EU, specifically states that contracting authorities can turn to either procedure if one of the alternative conditions below are satisfied. ${ }^{156}$

'(i) the needs of the contracting authority cannot be met without adaptation of readily available solutions; or

(ii) they include design or innovative solutions; or

(iii) the contract cannot be awarded without prior negotiations because of specific circumstances related to the nature, the complexity or the legal and financial make-up or because of the risks attaching to them; or

(iv) the technical specifications cannot be established with sufficient precision by the contracting authority with reference to a standard, European Technical Assessment, ${ }^{157}$ common technical specification or technical reference within the meaning of points 2 to 5 of Annex VII; or

(v) in response to an open or a restricted procedure, only irregular or unacceptable tenders are submitted. ${ }^{, 158}$

\footnotetext{
${ }^{156}$ See, J Davey, 'Procedures Involving Negotiation in the New Public Procurement Directive: Key Reforms to Grounds of Use and the Procedural Rules' [2014] PPLR 103, 111. M Burnett, 'The New Rules for Competitive Dialogue and the Competitive Procedure with Negotiation in Directive 2014/24 - What Might They Mean for PPP?' [2015] EPPPL, 62, 71.

157 The European Technical Assessment is a document providing for information about the performance of a construction product, to be declared in relation to its essential characteristics. In this respect, see the Construction Products Regulation (EU) No 305/2011.

${ }^{158}$ The Directives provide examples of what may represent an irregular or unacceptable tender, e.g. tenders which do not comply with the procurement documents or which are received late. If only irregular or unacceptable tenders are submitted, the contracting authority can enter into negotiations/dialogue without publishing a further notice only (i) with bidders who have met the exclusion and selection criteria of the original procedure, and their tenders are in 43
} 


\section{a) Pre-procurement.}

EU Directives do not specifically regulate pre-procurement. Nonetheless, it is worthwhile mentioning it because of its potential beneficial impact in the award of PPP contracts: market engagement at an earlier stage, which allows more focused and effective procedures. Procedures, specifications and award criteria promise to be better identified with a prior and deeper understanding of market capacity. Moreover, through pre-procurement, private operators have the possibility to plan ahead the beginning of formal competitions. Thus, pre-procurement could be highly beneficial for the award of PPP contracts. The latter, in fact, need the identification of the best technical specifications and award criteria according to the specific project that has to be delivered, which could be effectively defined during the pre-procurement phase where an effective market engagement took place. As of today, pre-procurement has the potential of expanding its importance. Most procedures have, in fact, to be carried out within tight time limits and full procurement documents have to be published at the beginning of procedures. ${ }^{159}$ Thus, preprocurement could be used to prepare in advance for formal competitions. Clearly, pre-procurement positive benefits highly depend on the public sector's ability to manage such a phase and on the willingness of private operators to take advantage of it. Critical aspects are related to the possible unfair advantages that private operators, participating in the pre-procurement phase, may enjoy. Article 41, Directive 2014/24/EU, specifically considers this possibility. ${ }^{160}$ If the involvement of a private operator in a pre-procurement phase distorts competition, and there is no other measure that can guarantee equal treatment among participants, than that economic operator will be excluded from the competition. ${ }^{161}$ Therefore, pre-procurement promises to be useful in cases of first-time procurements or innovative or complex contracts, such as PPPs. Anyway, it has to be considered that the value of this phase may be hindered by a poor coordination within the public sector and the exclusion of pre-procurement from the Directives. ${ }^{162}$

\section{b) Open Procedure.}

The open procedure allows any interested operator to submit a tender without having to prove in advance its capability. The existence of exclusion grounds - financial, professional and technical

accordance with the formal requirements of the tender procedure; and (ii) if it invites them all to participate. It is not clear if a new competition has to be carried out in cases where only tenderers which submitted their offers late or which did not somehow comply with the procurement documents were submitted. See P Telles, Luke R A Butler, 'Public Award Procedures in Directive 2014/24/EU' in F Lichère, R Caranta, S Treumer (eds), Modernising Public Procurement: the New Directive, (DJØF, 2014) 131.

${ }^{159}$ In this respect, see Article 53, Directive 2014/24/EU.

${ }^{160}$ As a result of certain CJEU cases in which the issue of exclusion of such tenderers arose. See, C-21/03 and C-34/03, Fabricom SA v Belgian State, [2005] I-01559 and case T-345/03, Evropaïki Dynamiki v Commission, [2008] II-00341.

${ }^{161}$ There is anyway provided a right of objection to such exclusion. An alternative means could be sharing information (exchanged during the pre-procurement phase) and allowing a proportionate amount of time to all tenderers to modify accordingly their submissions. Another pre-procurement aspect - relevant in the context of PPPs' awarding - is the confidentiality issue and information disclosure. Data indicated as confidential by economic operators or contracting authorities should not be revealed, being this anyway subject to national legislation on access to information and to all the specific disclosure requirements set out in the Directives. For instance, the obligation to notify candidates and tenderers of the evaluation results and the publication of contracts' award notices. See Article 21, Directive 2014/24/EU, Article 39, Directive 2014/25/EU and Article 28, Directive 2014/23/EU. The latter Article also provides that confidentiality 'shall not prevent public disclosure of non-confidential parts of concluded contracts, including any subsequent changes'.

${ }^{162}$ In this respect, see A Semple, A Practical Guide to Public Procurement (Oxford University Press, 2015$) 72$. 44 
'eligibility' of tenderers - can, in fact, be assessed after the substantive evaluation of tenders against contract award criteria. ${ }^{163}$ The specific order and the way in which tenders are evaluated varies. The precise structure of the procedure normally varies according to the number of bids submitted and the nature of the evaluation criteria. Usually, a large number of tenders are received and assessed. However, these are submitted for low average contract values. Thus, the open procedure does not represent a suitable awarding procedure for PPP contracts being, instead, adequate for the procurement of low value and straightforward goods and services.

\section{c) Restricted procedure.}

The restricted procedure entails a discrete selection phase that allows a larger control over the dimension and nature of the competition. Candidates are selected and evaluated upon qualitative criteria. Selection criteria are weighed and scored. ${ }^{164}$ Then, normally a minimum of five candidates are invited to tender. ${ }^{165}$ Following the 2014 reform, upon publication of the notice, full procurement documents have to be electronically available. This is in order to promote transparency of tender procedures and limit costs related to submissions of expressions of interest, which end up being not relevant after a deeper investigation. ${ }^{166}$ However, given the improved flexibility and higher availability of other multi-phase procedures, ${ }^{167}$ it is expected that the frequency with which the restricted procedure will be used - especially for the award of long term and complex contracts such as PPPs - will be low.

\section{d) Competitive Procedure with Negotiation.}

The competitive procedure with negotiation (hereinafter CPN) represents, together with the revised competitive dialogue, the most suitable procedure for the award of PPP contracts. The CPN replaces the negotiated procedure with prior publication ${ }^{168}$ and its main characteristic ${ }^{169}$ is its increased accessibility for contracting authorities. In fact, the 2014 reform mitigated the doubts surrounding the possibility for the public sector to negotiate contracts, which is a crucially important aspect especially in the award of PPPs, given their legal, technical and financial complexity. In the CPN, negotiations take place only at certain and specific stages. The Table below shows how the CPN is structured.

\footnotetext{
${ }^{163}$ Article 56, para 2, Directive 2014/24/EU and Article 76, para 7, Directive 2014/25/EU. Member States may decide to limit this option when implementing the Directives.

${ }^{164}$ In the open procedure eligibility can be instead assessed on a pass or fail basis. Article 65, Directive 2014/24/EU.

165 See, P Telles, Luke R A Butler, 'Public Award Procedures in Directive 2014/24/EU', op. cit., 140. The minimum number of candidates that will be invited to tender is indicated in the contract notice. This indication is anyway subject to the availability of a sufficient number of adequate candidates. There is also the possibility to indicate a maximum number. However, if there are two or more candidates that obtain the same score after the qualitative selection, all of them are invited to tender unless an objective and non-discriminatory selective rule for such event was previously set out. Short time periods are also envisaged.

${ }^{166}$ However, this change was not explicitly acknowledged in the recitals to the Directives. See, A Semple, A Practical Guide to Public Procurement, op. cit., 74.

${ }^{167}$ Competitive dialogue and competitive procedure with negotiation.

168 The negotiated procedure with prior publication still applies in the utilities sector. See, T Kotsonis, 'The 2014 Utilities Directive of the EU: Codification, Flexibilisation and Other Misdemeanours' [2014] PPLR, 174.

${ }^{169}$ That differentiates such a procedure from the old negotiated procedure. See J Davey, 'Procedures Involving Negotiation in the New Public Procurement Directive: Key Reforms to Grounds of Use and the Procedural Rules', op. cit., 103.
} 


\section{Selection phase}

2. Tender phase

3. Award phase a.

Call for tender and publication of documents (including award criteria, specifications and minimum requirements). b.

Selection of operators upon selection criteria. (minimum of 3 , unless fewer qualified candidates)

b.

Optional reduction of tenderers (through the application of award criteria).

b. Evaluation of the final tenders according to the award criteria. Confirmation of the eligibility and award of the contract without additional negotiations.

The CPN differs from the competitive dialogue mainly because the contracting authority sets out, before the invitation to tender, its requirements and specifications, upon which negotiations will later take place. ${ }^{170}$ As it will be seen, in the competitive dialogue, descriptive documents may indicate only the public sector's needs without identifying the nature or features of the solutions to be offered. The latter are progressively identified. Therefore, it is believed that the CPN represents an appropriate procedure whenever innovative or complex needs have to be dealt with, such as in the case of PPP arrangements. It may also be useful when there are specific commercial or technical characteristics, which are difficult to obtain without a dialogue with tenderers. ${ }^{171}$ In addition, as provided by Article 26, para 4, (iii), Directive 2014/24/EU, the use of the CPN may be justified in 'circumstances related to the nature, the complexity or the legal and financial make-up or because of the risks attaching to them', which is the typical context within which PPP contracts are awarded.

Overall, the CPN procedural rules laid down in Directive 2014/24/EU differ considerably from those applicable to the negotiated procedure with notice set out in Article 30, Directive 2004/18/EC. The main rules provided by Article 29, Directive 2014/24/EU, can be summarized as follows.

- In the CPN, any private operator can respond to a call for competition by providing the information requested for the qualitative selection. In the procurement documents, the contracting authority defines the subject matter of the procurement, describing its needs, requirements and award criteria. This information must allow private operators to understand the nature, scope of the procurement and decide whether to participate or not.

\footnotetext{
${ }^{170}$ Article 29, para 1, Directive 2014/24/EU.

${ }^{171}$ However, the CPN does not entail the same level of relationship with the preferred tenderer as the competitive dialogue does. For instance, the competitive dialogue allows the definition and optimization of the final tender. See $\mathbf{J}$ Davey, 'Procedures Involving Negotiation in the New Public Procurement Directive: Key Reforms to Grounds of Use and the Procedural Rules', op. cit., 107. 
- Economic operators invited (after the evaluation of the submitted information) can present an initial tender. The following negotiations are based on such tender. ${ }^{172}$

- Unless otherwise provided in para 4, contracting authorities have to negotiate initial and all following tenders to refine their content, with the exception of final tenders according to para 7. Minimum requirements and award criteria cannot be negotiated. If specified in the contract notice or invitation to confirm interest, contracting authorities can award contracts based on initial tenders, without carrying out any negotiation.

- Contracting authorities have to guarantee - while negotiating - equal treatment of tenderers. With this aim, they cannot offer information in a discriminatory way. ${ }^{173}$ They must inform non-excluded tenderers in writing of any modification of technical specifications or other procurement documents (with the exclusions of changes on minimum requirements). ${ }^{174}$

- CPN may be carried out in successive phases in order to limit the number of tenders to be negotiated (through the application of the award criteria indicated in the contract notice). ${ }^{175}$

- The conclusion of negotiations must be communicated to the remaining tenderers. ${ }^{176}$ The contracting authority controls the compliance of final tenders with the minimum requirements. Then it verifies the conformity with Article 56, para 1, evaluates the final tenders against the award criteria and awards the contract, as provided by Articles 66 to 69 .

\section{e) Competitive dialogue.}

The competitive dialogue was introduced in 2004 for the public sector as an alternative to the restricted and negotiated procedure with prior publication specifically for the award of complex contracts involving, for instance, an element of private finance, as in the case of PPPs. ${ }^{177}$ Its use can, in fact, be justified in circumstances of 'particularly complex contracts' ${ }^{178}$ Key feature of the

\footnotetext{
${ }^{172}$ Contracting authorities can reduce the number of participants in accordance with Article 65.

${ }^{173}$ See, P Telles, L Butler, 'Public Award Procedures in Directive 2014/24/EU', op. cit., 147. Both the CPN and the competitive dialogue stress the need to guarantee equal treatment of tenderers and availability of information among bidders in non-discriminatory way. As already mentioned, the latter aspect is subject to the confidentiality requirements set out in the 2014 Directives allowing limited possibilities for the public sector or private operator to refuse disclosure of information even if indicated as confidential. Article 21, Directive 2014/24/EU, Article 39, Directive 2014/25/EU and Article 28, Directive 2014/23/EU.

${ }^{174}$ In such a case, contracting authorities have to foresee an adequate amount of time for the non-excluded tenderers to change and re-submit their tenders accordingly. See M Burnett, 'The New Rules for Competitive Dialogue and the Competitive Procedure with Negotiation in Directive 2014/24 - What Might They Mean for PPP?', op. cit., $66,67$.

${ }^{175}$ The contracting authority has to state in advance whether it will do so. See Article 29, para 6, Directive 2014/24/EU and A Semple, A Practical Guide to Public Procurement, op. cit., 75.

${ }^{176}$ In addition, the contracting authority indicates when any new or modified tenders can be submitted. See P Telles, Luke R A Butler, 'Public Award Procedures in Directive 2014/24/EU', op. cit., 153.

177 In this respect, see point 26, Green Paper on Public-Private Partnerships and Community Law on Public Contracts and Concessions Brussels, 30.4.2004 COM (2004) 327 final. 'The competitive dialogue procedure should provide the necessary flexibility in the discussions with the candidates on all aspects of the contract during the set-up phase, while ensuring that these discussions are conducted in compliance with the principles of transparency and equality of treatment, and do not endanger the rights which the Treaty confers on economic operators.' The competitive dialogue is today foreseen also in the utilities Directive. Formally, the competitive dialogue was not envisaged in the old utilities Directive 2004/17/EC. There was no provision for the competitive dialogue. Nonetheless, contracting authorities could use it as a kind of negotiated procedure, which they could - and still can - apply without justification. Contracting authorities could unrestrictedly use the negotiated procedure with a prior call for competition. Article 1, para 9, letter c) and Article 40, Directive 2004/17/EC. See, T Kotsonis, 'The 2014 Utilities Directive of the EU: Codification, Flexibilisation and Other Misdemeanours', op. cit., 175.

${ }^{178} 24$ Member States implemented this procedure. The UK and France are the two countries that advertised the majority of competitive dialogues in the OJEU between 2006 and 2011. See A Semple, A Practical Guide to Public 47
} 
competitive dialogue is the possibility to engage in effective rounds of dialogue with candidates prior to the preferred tenderer stage, and to do so in a structured way. ${ }^{179}$ It is a procedure that lies somehow between pure negotiations and the limitations of the open and restricted procedures. In general terms, it keeps alive a competitive tension while technical and commercial features of a tender are formulated. The value of contracts awarded through the competitive dialogue procedure is normally high if compared to contracts' value awarded via open and restricted procedures. Among the 2014 changes, the possibility to 'fine-tune' tenders ${ }^{180}$ was replaced with the ability to 'optimize' them. This was most likely done with the aim of creating greater flexibility. ${ }^{181}$ Criticalities of the procedure may be related to its potential misuse and long duration. ${ }^{182}$ Thus, skills, time and resource commitment are important for the competitive dialogue to work effectively. It is too soon to predict the impact on its use after the 2014 introduction of two new procedures. ${ }^{183}$ Nonetheless, even if the competitive dialogue does not represent anymore the exceptional procedure through which greater engagement with tenderers is allowed, it still offers an important balance between negotiation and structured competition. At the most, it allows contracting authorities to clarify their requirements after targeted interactions with potential contractors. In this regard, following the 2014 Directives, negotiations with the preferred bidder can now be carried out in order to:

\begin{abstract}
'confirm financial commitments or other terms contained in the tender by finalising the terms of the contract provided this does not have the effect of materially modifying essential aspects of the tender or of the public procurement, including the needs and requirements set out in the contract notice or in the descriptive document and does not risk distorting competition or causing discrimination. ${ }^{184}$
\end{abstract}

This provision takes into consideration the possibility that not all aspects of a tender may be agreed upon during the dialogue. Thus, it aims at rendering the procedure more effective by being closer to the reality of public procurement. As it was already provided, contracts awarded with the competitive dialogue have to consider qualitative aspects as part of award criteria and, hence, cannot be awarded based on only the lowest price or cost. In addition, at least 3 candidates must be

Procurement, op. cit., 77. In the UK, the competitive dialogue is highly used because of the low rate application of the negotiated procedure compared to other Member States and the greater use of large scale out-sourcing and private finance initiative contracts. Also in the Netherlands, the competitive dialogue procedure is highly applied. In this latter respect see, M Nagelkerke, J Muntz-Beekhuis, 'Competitive Dialogue in the Netherlands' in S Arrowsmith, S. Treumer (eds), Competitive Dialogue in EU Procurement, (Cambridge University Press, 2012) 491, 526.

${ }^{179}$ See below Table 4.

${ }^{180}$ Several authors studied and explored the competitive dialogue and, particularly, the somehow ambiguous provision of Article 29, Directive 2004/18/EC within which tenders could be 'clarified, specified and fine-tuned' after their submission, only if this did not 'involve changes to the basic features of the tender or the call for tender'. See, among others, S Arrowsmith, S Treumer, Competitive Dialogue in EU Procurement, (Cambridge University Press, 2012) and C Kennedy-Loest, 'What can be done at the Preferred Bidder Stage in Competitive Dialogue?' [2006] PPLR 316.

${ }^{181}$ It is not clear whether tenders may by downgraded or merely upgraded. Some authors, considered 'optimize' as a term implying more flexibility than 'fine-tune'. See T Kotsonis, 'The 2014 Utilities Directive of the EU: Codification, Flexibilisation and Other Misdemeanours', op. cit., 176.

${ }^{182}$ With regard to the duration of the competitive dialogue, it is now mandatory to have an 'indicative timeline' in the notice or tender documents. However, it is still uncertain whether this requirement refers to the dialogue or the contract. See A Semple, A Practical Guide to Public Procurement, op. cit., 76.

${ }^{183}$ The CPN and the innovation partnership.

${ }^{184}$ Article 30, para 7, Directive 2014/24/EU. 
invited to the dialogue and the number invited to deliver final tenders has to create 'genuine competition in so far as there are enough tenders, solutions or qualified candidates'. By referring to the award criteria set out at the begging of the procedure - in the procurement documents - the number of tenders to be negotiated, or solutions to be discussed, can be reduced. ${ }^{185}$ The Table below shows how the procedure is structured.

a.

$\begin{array}{cl}\text { 1. Selection } & \text { Call for competition and } \\ \text { phase } & \begin{array}{l}\text { publication } \\ \text { of detailed documents } \\ \text { identifying needs and award } \\ \text { criteria, indicative time line. }\end{array}\end{array}$

a. $\quad$ b.

2. Tender One or more rounds of tender phase submissions and dialogue with the selected candidates.

a.

3. Award phase b.

Selection of operators upon selection criteria.

(minimum of 3 unless fewer qualified candidates).

Optional reduction of number of tenderers applying award criteria.

End of dialogues, deadline for final tenders. b.

Evaluation and selection of the preferred tenderer.

\begin{abstract}
c. Optional negotiations with the preferred tenderer to confirm financial and other commitments leading to the award of the contract.
\end{abstract}

Table 4 Competitive dialogue procedure.

The most relevant changes of Article 30, Directive 2014/24/EU, to the procedural rules set out in Article 29, Directive 2004/18/EC, can be identified as follows.

- Article 30, para 1, provides as an award basis the 'best price-quality ratio'. Directive 2004/18/EC, instead, indicated the 'most economically advantageous tender'. This change reflects the definition of Article 67, para 2, Directive 2014/24/EU.

- Article 30, para 2, states that contracting authorities should foresee an indicative time line for the award procedure.

- Article 30, para 3, states that any agreement on the sharing of solutions or confidential information may not 'take the form of a general waiver but shall be given with reference to the intended communication of specific information'. ${ }^{186}$

- Article 30, para 6, states that tenders can be 'clarified, specified and optimised' by contracting authorities. Article 29, para 6, Directive 2004/18/EC, instead, used the words 'clarified, specified and fine-tuned'.

-'Negotiations', 'financial commitments', 'finalising the term of the contract' and 'materially modifying', represent probably the most relevant - especially with respect to the award of PPP contracts - changes of Article 30 if compared to Article 29, para 7, Directive 2004/18/EC. The term 'negotiations' replaced the previous wording

\footnotetext{
185 Article 66, Directive 2014/24/EU.

186 This provision promises to have an important impact in the award of PPP contracts. See M Burnett, 'The New European Directive on the Award of Concession Contracts, Promoting Value for Money in PPP Contracts?', op. cit., 67. 
'clarifying aspects of the tender or confirming commitments'. Moreover, specifically mentioned are now 'financial commitments'. The scope of the negotiation is then indicated as the need to finalize the contract. In addition, the objective of negotiations in Article 30, para 7, is qualified by referring to 'material modification', instead, of 'modification'. 187

Overall, the new provisions of the competitive dialogue and the CPN increased the suitability of such procedures for the award of PPP contacts. This is mainly because contracting authorities can now count on wider justification grounds for the use of such multi-phase and flexible procedures. For instance, for the use of either procedure:

- a contract no longer has to be 'particularly complex', as it was as envisaged by Directive 2004/18/EC, and

- there is no reference to 'exceptional cases', as in the negotiated procedure with notice.

Moreover, Directive 2014/24/EU does not illustrate the conditions that justify the use of the competitive dialogue and the CPN. Specifically,

- the meaning of a 'readily available solution',

- the extent to which a solution has to be 'innovative',

- what aspects or degree of complexity or risks have to be considered, and

- to what extent the condition on 'technical specifications' that 'cannot be established with sufficient precision by the contracting authority’ must be interpreted.

Recital 43, Directive 2014/24/EU, foresees only one limit: 'in respect of off-the-shelf services or supplies that can be provided by many different operators on the market, the competitive procedure with negotiation and competitive dialogue should not be used.' Therefore, it is believed that after the transposition of the 2014 Directives, PPP contracts will keep being awarded through the competitive dialogue. The CPN is also expected to have a high degree of application. In this regard, it will have to be considered whether the lack of procedural rules under Directive 2014/23/EU will have an impact on the awarding of PPP contracts. ${ }^{188}$ In other words, it remains to be seen whether

\footnotetext{
${ }^{187}$ Article 29, para 7, Directive 2004/18/EC. Especially the modifications set out in Article 30, paras 6 and 7, Directive 2014/24/EU, are likely to positively support the use of such a procedure for the award of long-term, high value and complex contracts such as PPPs. Ibid, 68.

${ }_{188}$ On Directive 2014/23/EU see below, para 4.2.4.2. In brief, according to Directive 2014/23/EU, contracting authorities are free to organise the procedure as they prefer. There are few procedural rules. There is no indication on whether the award procedure should be carried out in one or more phases. Selection criteria, and the kind of evidence that should support them, are not defined. Article 38 only states that participation conditions have to be included in the concession notice and must allow the performance, by the economic operator, of the concession. Participation conditions must refer to the professional, technical and economic capability of the private party. Evidence for qualification criteria has to be based on 'self-declarations' and 'references'. The award criteria are not identified. Article 41 merely states that they have to be objective and compliant with the principles of transparency, non-discrimination, equality of treatment and proportionality. In addition, awarding criteria must confirm the recognition of the economic advantage for the contracting authority. They have to relate to the subject-matter of the concession, they cannot guarantee to the contracting authority an unlimited discretional power of choice and can cover environmental, social or innovative criteria. The order of importance of award criteria is not set, but has to be indicated. It can be changed if there are tender submissions entailing innovative solutions with an unforeseeable and exceptional level of performance. 50
} 
this will lead to increased legal challenges that will hinder - in the long term - the award of PPPs, which take the form of concessions.

\section{f) Innovation Partnership.}

In general, contracts for research and development services are excluded from the scope of the Directives. There is an exception for the case in which benefits of this kind of services are reserved exclusively to the public sector, which also entirely pays for them. ${ }^{189}$ Nevertheless, this exception does not cover the purchase on a commercial scale of the resulting goods or services. In order to fill in this gap the innovation partnership was introduced. The objective of an innovation partnership is the development and following acquisition of innovative products, services or works 'provided that they correspond to the performance levels and maximum costs agreed between the contracting authorities and the participants'. ${ }^{190}$ Thus, the innovation partnership covers the early research and development phases and the final purchase on a commercial scale. Such a procedure allows the public sector to implement research and development activity benefits - publicly funded or cofinanced - in its own operations. The innovation partnership differs from the other procedures because it can end with the award of a contract to either one or more economic operators. Thus, it can be considered as an application of the CPN aiming at creating a partnership with one or several partners. However, the innovation partnership can count on additional rules on structure and contracts' stages. Partnerships must be progressively structured, with halfway targets and payments through instalments. Selection criteria have to deal with participants' ability in the research and development field. ${ }^{191}$ The actual procedure differs from the Commissions' original scheme. It is more flexible as it eliminated the requirement of guaranteeing an 'adequate profit' for the private operator. ${ }^{192}$ The Table below shows how the innovation partnership procedure may present itself.

b.

a.

Call for competition and publication

1.Selection phase of descriptive documents. Submission of requests to participate in response to contract notice.
Negotiations with candidates, which may take place in successive stages. Selection of candidates particularly by applying criteria concerning candidates' capacities in the fields of research and development and development and implementation of innovative solutions.

a.

2.Tender phase The economic operators invited by the contracting authority submit research and innovation projects.

See M Burnett, 'The New European Directive on the Award of Concession Contracts, Promoting Value for Money in PPP Contracts?' [2014] EPPPL, 86, 103.

${ }^{189}$ Article 14, Directive 2014/24/EU and Article 32, Directive 2014/25/EU.

190 Article 31, para 2, Directive 2014/24/EU.

${ }^{191}$ Procurement documents must cover intellectual property arrangements and the various activities to be carried out for the development of innovative solutions. In this respect, it can be difficult to foresee appropriate requirements and select adequate partners at the beginning of the procedure. See P Cerqueira Gomes, 'The Innovative Innovation Partnerships Under the 2014 Public Procurement Directive' [2014] PPLR, 211, 218.

192 Proposal for a Directive of the European Parliament and of the Council on Public Procurement, Brussels, 20.12.2011, COM (2011) 896 final, 2011/0438 (COD) 60. In addition, the aim was to avoid as much as possible potential State aid implications. 
b.

a.

3.Award phase $\quad \begin{aligned} & \text { Award of the contract to one or more } \\ & \text { economic operators. }\end{aligned}$

Definition of the structure of the partnership in phases reflecting the degree of innovation of the proposed solution and the sequence of the research and innovation activities required for the development of the innovative solution.

Table 5

Innovation partnership procedure.

The innovation partnership could be used as an adequate awarding procedure for PPP contracts. It is, in fact, suitable in cases of long-term projects, which include the possibility of eventual commercial acquisitions. Moreover, innovation partnerships are structured in order to reduce some of the risks related to innovation procurement through a progressive interaction with suppliers and the possibility of terminating one or more contracts at the end of each stage. As of today, with a potential positive benefit for PPP arrangements, Horizon 2020 and other EU projects are supporting the public sector's innovation procurement in different sectors, e.g. health, construction, IT services and equipment. ${ }^{193}$

\section{g) Negotiated Procedure without Prior Publication.}

The negotiated procedure without prior publication of a notice can be used by contracting authorities only in exceptional cases, which do not usually occur in the context of PPPs' awards. For instance, Article 32, Directive 2014/24/EU, sets out that the use of such a procedure may be justified in cases of 'extreme urgency brought about by events unforeseeable by the contracting authority." ${ }^{194}$ It can be also used if 'no tenders or no suitable tenders or no requests to participate or no suitable requests to participate have been submitted in response to an open procedure or a restricted procedure'. ${ }^{195}$

\section{h) Design Contests.}

A design contest allows the identification by a jury of a winning plan and/or design, after a competition. Design contests are usually used in the architecture field. However, following the 2014 reform, they can also cover engineering, data processing or 'financial engineering' plans. ${ }^{196}$ Design

\footnotetext{
${ }^{193}$ Initiatives and programmes can be found at https://ec.europa.eu/programmes/horizon2020/.

${ }_{194}$ Article 32, para 2, let. c), Directive 2014/24/EU.

195 Article 32, para 2, let. a), Directive 2014/24/EU. A tender is considered unsuitable if it is 'irrelevant to the contract, being manifestly incapable, without substantial changes, of meeting the contracting authority's needs and requirements as specified in the procurement documents'. Article 32, para 2, let. a), second period, Directive 2014/24/EU. Article 32, para 3, let. b), Directive 2014/24/EU, provides for similar circumstances compared to those already foreseen in Article 31, para 2, let. b) and para 4, Directive 2014/18/EC. The possibility of awarding additional services or works (essential because of unforeseen events and up to $50 \%$ of the original contract value) has been instead eliminated.

${ }^{196}$ Recital 120, Directive 2014/24/EU. Reference is made to the development of EU funded SME support programmes. In this respect, see, M Trybus, 'The Promotion of Small and Medium Sized Enterprises in Public Procurement: a Strategic Objective of the New Public Sector Directive?' in F Lichère, R Caranta, S Treumer (eds), Modernising Public Procurement: the New Directive, (DJØF, 2014) 255. 
contests can be used as a preliminary phase before the awarding of a public service contract and/or the award of prizes or payments to competitors. A specific notice details the procedure to be followed, the selection, award criteria and whether the contracting authority is bound by the jury's decision. Article 80, Directive 2014/24/EU, states that procedures can be tailored to the needs of each contest. If there is a selection phase, selection criteria have to be clear, non-discriminatory and the identified number of participants must be sufficient to allow competition. ${ }^{197}$ There is little space for redefinition of plans when discussing with contestants. Therefore, design contests are usually not appropriate for the award of PPP contracts being, instead, suitable for projects where the value and quality of plans can be easily evaluated upon initial submissions. In the case of public contracts that include a complex design, the competitive dialogue procedure, the innovation partnership or the CPN may be more adequate. The Table below shows how the design contest procedure may present itself.
a. Contracting authorities that intend to carry out a
1. First stage design contest express their intention by means of a contest notice.
b. Candidates submit requests to participate in response to the contest notice. Selection of candidates.
2. Second a. Selected economic operators submit their plans Stage or designs.

b. Examination of the jury of plans and designs submitted.

\section{Third Stage}

a. Identification of the winning plan or design.

b. Notification of the results of the contest.

\subsubsection{The 2014 Concessions Directive.}

As mentioned, the 2014/23/EU Directive (or Concessions Directive) is particularly important for PPP schemes as concession contracts are one of the main legal types through which PPPs may take form. This paragraph provides a general overview of the essential reasons that led to the enactment of the 2014 Concessions Directive ${ }^{198}$ in order to then highlight its essential characteristics.

It has to be preliminarily recalled that concessions are characterised by the way through which concessionaires recover their costs and profits. The supplier, or better the concessionaire, obtains a reward for the investment made in the construction of infrastructure or in the provision of a service

\footnotetext{
${ }^{197}$ Members of the jury are independent and act independently in their decisions and assessments. In case there is a member of a certain profession who must compete, a least a third of the jury has to be of that profession. Moreover, during evaluation, contestants are anonymous and the jury records its assessments, comments or clarifications. See A Semple, A Practical Guide to Public Procurement, op. cit., 84.

${ }^{198}$ Directive 2014/23/EU. Persuasive reasons were put forward for a legislative initiative on concessions. These were, mainly, the need to assure greater legal certainty and value for money for long term contracts with a high level of investment of the private business world and a significant financial commitment by public authorities to develop Europe's and domestic infrastructures.
} 
with the right to exploit this infrastructure or service. A straightforward example of this is a toll road where the concessionaire's remuneration arises out the tolls paid by road users. Since concessions are large-scale contracts requiring long-term financial commitments and a high level of investment, legal certainty is a priority. ${ }^{199}$ The 2014 Concession Directive on the award of concession contracts aimed especially at ensuring the latter.

The historical differences between Member States in the approach to concessions explain in part why only in 2014 legislative action was taken in this field. ${ }^{200}$ Work and service concessions were, in fact, excluded from the scope of Directive 2004/17/EC. ${ }^{201}$ Moreover, Directive 2004/18/EC regulated only certain public work concessions through a limited set of rules. ${ }^{202}$ In spite of these exclusions, concessions with a sufficient cross-border interest were awarded in compliance with the EU principles of equal treatment, non-discrimination and transparency. Nonetheless, a high degree of legal uncertainty impaired the use of concessions schemes as the Treaty principles did not provide sufficient guidance on how award procedures had to be carried out. ${ }^{203}$ Therefore, the European Commission - acknowledging these difficulties - decided to take action ${ }^{204}$ mainly in order to avoid legal uncertainty hindering the functioning of the four freedoms and, hence, of the Internal Market. Thus, with the goal of addressing the need for greater legal certainty in this field and an actual regulation of the concession contracts' category, Directive 2014/23/EU was published on March 28, 2014, entering into force 20 days later pursuant to Article $52 .{ }^{205}$ The concession

${ }^{199}$ Especially in terms of clarification of definitions and EU rules. See the Report on the Public Consultation on the Green Paper on Public-Private Partnerships and Community Law on Public Contracts and Concessions, Commission Staff Working Paper, SEC (2005) 629.

${ }^{200}$ Reference is made to disparity of definitions and regimes in Member States, defective application of the principles of transparency, equal treatment and non-discrimination and insufficient legal certainty arising out CJEU case law. See the Communication from the Commission to the European parliament, the council, the European economic and social committee and the committee of the regions on Public-Private Partnerships and Community Law on Public Procurement and Concessions, Brussels, 15.11.2005 COM (2005) 569 final, 8. Moreover, insufficient legal protection of bidders. In fact, in the case of concessions not covered by the Directives, private operators could not refer to the provisions of the Remedies Directive. Directive 2007/66/EC of the European Parliament and of the Council of 11 December 2007 amending Council Directives 89/665/EEC and 92/13/EEC with regard to the improvement of the effectiveness of review procedures concerning the award of public contracts.

${ }^{201}$ Article 18, Directive 2004/17/EC. See, S Arrowsmith, The Law of Public and Utilities Procurement, Regulation in the EU and UK (Sweet \& Maxwell, 2014) 427. Sue Arrowsmith holds that, according to the CJEU in the Teleaustria judgement, the Commission's original proposals on the coordination of procedures on the award of public service contracts (which resulted in Directive 92/50) expressively included provisions on concessions' regulation. However, the Council deleted them. Concessions were excluded from the Services Directive because the differences between Member States in the use of concessions would have brought a situation of 'great imbalance' in regulation. Concessions were then excluded also from the Utilities Directive because concessions existed only in one Member State and further investigation was needed. According to Sue Arrowsmith, in the legal systems of some Member States concessions are not considered as ordinary procurement, but as a different type of legal relationship and have not been regulated by public procurement law, but by separate rules covering the award and operations of such schemes.

${ }^{202}$ For instance, see Articles 56 to 61 of Directive 2004/18/EC of the European Parliament and of the Council of 31 March 2004 on the coordination of procedures for the award of public works contracts, public supply contracts and public service contracts regulating advertising issues and time limits.

${ }^{203}$ See M Burnett, 'The New European Directive on the Award of Concession Contracts, Promoting Value for Money in PPP Contracts?', op. cit., 98.

${ }^{204}$ See, for instance, Recital 1 of the Concessions Directive.

${ }^{205}$ The deadline for the transposition by EU Member States of the Concessions Directive into national legal systems was April 18, 2016. In principle, the provisions of the Concessions Directive are not binding prior to the date of transposition. Before that date, the award of services concessions is nevertheless subject to the general principles set out by the CJEU in its case law and the award of works concessions falls under the directive 2004/18/EC. 
Directive is now the key reference point for the award of public and utility contracts that take the form of concessions. ${ }^{206}$

Directive 2014/23/EU replicates several provisions of the 2014 public sector and utilities Directives. ${ }^{207}$ Many provisions and definitions are, in fact, the same in all three Directives. ${ }^{208}$ For instance, the innovative solution of the so-called light touch regime for social, health and other specific services provided for under the EU's new public sector Directive can be found also in the Concessions Directive. ${ }^{209}$ The Concessions Directive is applicable to works and services concessions $^{210}$ equal to and above specific financial reference standards set out in Articles 8 and 9. ${ }^{211}$ The calculation of the value of complex, long-term concession contracts entails the consideration of many aspects. Therefore, Directive 2014/23/EU sets out a transparent and objective approach - to be reproduced in the concession documents - that guides such evaluation. Directive 2014/23/EU provides for a detailed definition of the term concession, which comes from the CJEU case law and stresses the right of exploitation and the transfer of the economic risk. ${ }^{212}$ Article 5, para 1, Directive 2014/23/EU, remarks that the consideration for the execution of the work or provision or management of the service consists of 'either solely in the right to exploit [the works or services] or in that right together with payment.' Article 5, para 1, further states that the definition of concession should embrace a transfer of operating risk to the concessionaire. Such transfer is considered sufficient when there are no guarantees that the concessionaire will regain its investment. Directive 2014/23/EU highlights that operating risks are risks outside parties' control, such as the exposure to market uncertainties. ${ }^{213}$ Thus, the risk that has to be transferred must be a risk of loss, the assessment of which has to be carried out taking into account the net present value of all investments, costs and revenues. ${ }^{214}$ Hence, an arrangement preventing an economic operator to make losses would not involve the required transfer of operating risk. ${ }^{215}$ Once an operating risk is transferred, it is not relevant - for the identification of a concession contract - where the remuneration comes from. The remuneration has to be in any case based exclusively on the demand for the supply of the considered service or infrastructure delivered. Moreover, the entire operating risk does not have to be necessarily transferred in order to have a concession contract. ${ }^{216}$ Lastly, the

\footnotetext{
${ }^{206}$ Service concessions in the public contract sector and both works and services in the utilities sector. Article 1, Directive 2004/23/EU.

207 Such as those on exclusions, reserved concessions, modifications and termination, compliance by economic operators and sub-contractors with environmental, social and labour obligations. See Directive 2014/24/EU of the European Parliament and of the Council of 26 February 2014 on public procurement repealing Directive 2004/18/EC OJ L 4/65. Directive 2014/25/EU of the European Parliament and of the Council of 26 February 2014 on procurement by entities operating in the water, energy, transport and postal services sectors repealing Directive 2004/17/EC, OJ L 94.

${ }^{208}$ For instance, the new provisions on the concept of 'economic operator'.

${ }^{209}$ See Article 19, Directive 2014/23/EU.

${ }^{210}$ The Concessions Directive does not cover supplies because they do not entail exploitation of risk.

${ }^{211}$ The actual threshold is of 5.186.000 Euros. Such a value should reflect the clear cross-border interest of concessions for economic operators located in Member States other than that of the contracting authority or contracting entity. Recital 23, Concessions Directive.

${ }^{212}$ See, inter alia, AG Fennelly in C-324/98, Telaustria Verlags GmbH and Telefonadress GmbH v Telekom Austria $A G$, [2000] I-10745. AG Pergola in C-360/96, Gemeente Arnhem v BFI Holding BV, [1998] I-06821. C-231/03, Consorzio Aziende Metano v Comune di Cingia de' Botti, [2005] I-07287. C C-458/03, Parking Brixen GmbH v Gemeinde Brixen and Stadtwerke Brixen AG, [2005] I-08585.

${ }^{213}$ See Recital 20, Concessions Directive.

${ }^{214}$ See Recital 20, Concessions Directive.

${ }^{215}$ See Recital 18, Concessions Directive.

${ }^{216}$ See Recital 18, Concessions Directive.

55
} 
risk does not have to be substantial, as it was indicated in the first wording of the draft Concession Directive. $^{217}$

Directive 2014/23/EU keeps alive the distinction between concession contracts and other public and utility contracts. In this regard, it should be borne in mind that there is no real economic justification behind the distinction between concessions and other regulated public contracts. ${ }^{218}$ The original call was for an alternative and more radical approach and implied the creation of a separate Directive covering complex contracts, including concessions and PPPs. ${ }^{219}$ The idea for such a legislative instrument was to deal with long-term contracts, entailing negotiations, lengthy and costly procurement procedures, consortia bidders and private finance. Instead, it was enacted the 2014 Concessions Directive. Anyway, the latter aimed at enhancing legal certainty, confirmed the CJEU case law and provided certain details on specific aspects. ${ }^{220}$

Not only the definition of concession, but also the set of rules regulating concessions' awards recalls the CJEU line of thinking. These rules require, in fact, the application, by contracting authorities, of the EU general principles of equal treatment, non-discrimination, transparency and proportionality. ${ }^{221}$ However, they do not provide for a specific award procedure. They merely outline a relatively broad awarding process, which includes rules on the initial publication of a concession notice in the OJEU. ${ }^{222}$ No indications are provided on whether the procedure should be carried out in one or more phases. ${ }^{223}$ In addition, selection criteria are not identified. Article 38, Directive 2014/23/EU, merely states that participating conditions have to be included in the concession notice. They have to relate the concessionaire's performance, its professional and economic capability. Award criteria are also not defined. Article 41, Directive 2014/23/EU, only provides that they must be based on objective criteria, comply with the principles of transparency, non-discrimination, equality, proportionality and guarantee an effective competition. ${ }^{224}$ Recital 73 , Directive 2014/23/EU, states that they must allow the identification of the tender that offers an overall economic advantage to the contracting authority. Furthermore, award criteria must be linked to the subject matter of the concession and cannot allow unlimited discretion to contracting authorities. It can be anticipated that award criteria may be environmental, social or innovation related. $^{225}$ They must come along with information requirements allowing the verification of the submitted data. The order of importance of award criteria has to be set out by each contracting authority and may be revised in case of innovative tenders with an unforeseen and exceptional level

\footnotetext{
${ }^{217}$ For an analysis of the concept of operating risk in concession contracts, as defined by the CJEU, see below paragraph 4.2.4.3.

${ }_{218}$ See, for instance, R Craven, 'The EU's 2014 Concessions Directive' [2014] PPLR, 197.

219 European Commission, Evaluation Report: Impact and Effectiveness of EU Public Procurement Legislation (Commission Staff Working Paper) SEC (2011) 853 final.

${ }^{220}$ Such as the tender selection and award criteria.

${ }^{221}$ See Articles 3 and 30, Concessions Directive.

${ }^{222}$ Article 3, para 1 of the 2014/23/EU Directive. The concession notice has to include participating conditions (which have to relate, and be proportionate, to the performance of the economic operator, its technical and financial capability and its economic characteristics).

${ }^{223}$ Anyway, procedural rules cannot compensate for other necessary elements such as good governance, effective competition and anti-corruption law, effective audit, political, medial and civil society control, judicial support, transparency and accountability in public finance, ethical guidelines for the public and private sectors, control of lobbyists, effective whistleblowing protection and contract management. On the key relevance of the latter aspect see, M Burnett, 'PPP contract management-Still in Need of More Attention?' [2013] EPPPL 217, 230.

${ }^{224}$ Article 82, Directive 2014/25/EU.

${ }^{225}$ See Article 41, para 2, Directive 2014/23/EU. 
of functional performance. ${ }^{226}$ Thus, overall, the rules regulating tenders' assessment are significantly fewer if compared to those of Directives 2014/24/EU and 2014/25/EU. ${ }^{227}$ All three 2014 Directives provide, instead, for similar rules on contract performance after the awarding phase. These cover sub-contracting, contract modification, termination, monitoring and reporting. ${ }^{228}$

As final remark, it can be stated that the 2014/23/EU Directive - envisaged since 2004 overall represents an important achievement. However, only little steps forward have been taken. ${ }^{229}$ Because of the disputed nature of EU public contracts law in this area, ${ }^{230}$ most of the steps taken represent an endorsement of the CJEU case law. Thus, on the one hand, the Concessions Directive achieved its goal by providing a somehow clearer legal framework that allows flexibility for awarding bodies. Remarkably, and given the scope of this thesis, it clearly expresses the possibility of having environmental, social and/or innovative-related award criteria. On the other hand, this separate Directive that differentiates concessions from other complex public contracts may likely lead to an over-burocratization and less accessible EU public contracts' regime. ${ }^{231}$

\subsubsection{Concessions, operating risk and CJEU case law.}

The key relevance of the concept of operating risk in the notion of 'concession' has been well clarified by the CJEU in several decisions. This paragraph examines only those that can be considered milestones in the understating of this concept.

First of all, the Parking Brixen case. ${ }^{232}$ In this case, the Municipality of Brixen directly awarded, without an open and competitive procedure, the management of two car parks to a jointly held company. The qualification of the relationship as a public contract or as a concession was at the centre of the first question brought before the CJEU. The Advocate General, recalling the Telaustria case, ${ }^{233}$ the mentioned Commission's Interpretative Communication on concessions ${ }^{234}$ and Directive 2004/18/EC, stated that 'unlike a public service contract, a service concession is characterised by the fact that, in consideration for the service in question, the service provider obtains from the contracting authority the right to exploit for payment its own service. ${ }^{235}$ In other words, 'where a contracting authority assigns the management of a public car park to an undertaking which may charge a fee for the use of the car park and, in return, undertakes to pay annual compensation to the contracting authority does not constitute a public service contract [...]

\footnotetext{
${ }^{226}$ Article 41, para 3, Directive 2014/23/EU.

${ }^{227}$ For instance, see Article 41, Directive 2014/23/EU and Article 67, Directive 2014/24/EU.

${ }^{228}$ See Articles 42, 43, 44 and 45, Directive 2014/23/EU.

${ }^{229}$ In this respect, see for instance, A Sanchez Graells, 'The Continuing Relevance of the General Principles of EU Public Procurement Law after the Adoption of the 2014 Concessions Directive' University of Leicester School of Law, Research Paper n. 15-12, 2015, available at SSRN, http://papers.ssrn.com/sol3/papers.cfm?abstract_id=2581683.

${ }^{230}$ There has been a disparity of views between Member States on concessions since the 1990s. At that time, directives on the award of public works contracts, with limited procedural rules on works concessions (Directive 93/37/EEC), and on public service contracts, with no mention of service concessions (Directive 92/50/EEC), were adopted. See, M Burnett, 'PPP contract management-Still in Need of More Attention?', op. cit., 86.

${ }^{231}$ See M Burnett, 'PPP contract management-Still in Need of More Attention?', op. cit., 98.

${ }^{232}$ C-458/03, Parking Brixen GmbH v Gemeinde Brixen and Stadtwerke Brixen AG, [2005] I-08585.

${ }^{233}$ Paras 57 and 58, C-324/98, Telaustria Verlags GmbH and Telefonadress GmbH v Telekom Austria AG, [2000] I10745 .

${ }^{234}$ Commission Interpretative Communication on Concessions under Community Law (2000/C 121/02).

235 Point 29 of the Opinion of the Advocate General Kokott, delivered on 1 March 2005, C-458/03, Parking Brixen GmbH v Gemeinde Brixen and Stadtwerke Brixen AG, [2005] I-08585. 
but a service concession [...]. ${ }^{236}$ Along the same lines went the decision of the CJEU. It moved from the definition provided by Directive 2004/18/CE and remarked that the existence of an operating risk allows the qualification of a relationship between a contracting authority and a private operator as a concession. ${ }^{237}$

The judgement of the CJEU in the Case 437/07 is also worth mentioning. ${ }^{238}$ Here, the Municipality of the city of L'Aquila qualified and awarded a concession for the planning and realization of a road tram vehicle for public transportation. In this case, the concessionaire had to undertake the construction of the vehicle and, in return, it would have received, as compensation, a sum equal to a percentage of the realization costs $(60 \%)$ and a predetermined annual sum paid by the local public transport entity, who would have in the end managed the public transportation service. $^{239}$ The CJEU clearly held that there can be a service concession contract if the agreed remuneration consists of the right of the concessionaire to exploit the service or asset delivered. In addition, the concession holder must assume the operating risk of the service in question. ${ }^{240}$ Therefore, failing to transfer to the concessionaire the risks linked to the provision of the service, the transaction constitutes a public service contract and not a public service concession. ${ }^{241}$ Upon these considerations, the CJEU re-qualified the contract as a public service contract highlighting that, in the case at stake, the assumed 'concessionaire' would have not managed the asset, which was instead entrusted to the local public transportation entity. Hence, the concessionaire would have not borne any operating risk. This is also the case if it is considered that the private party's compensation was pre-determined. ${ }^{242}$

The centrality of the operating risk element emerged also in the CJEU judgment on the use of urban waste in Sicily. ${ }^{243}$ In this case, the Court firmly excluded that the compensation means provided by the contested agreements implied an operating risk borne by the private operator. In fact, 'not only is the operator essentially remunerated by the Commissioner by means of a fixed royalty per tonne of waste transferred to it [...], but [...] under the agreements at issue, the Commissioner undertakes, first, that all the municipalities concerned will transfer all of the remaining part of their waste to the operator and, secondly, that a minimum annual quantity of waste will be transferred to it. The agreements at issue provide, moreover, for the adjustment of the amount of the royalty if the annual quantity of waste actually transferred falls below $95 \%$ or exceeds $115 \%$ of the guaranteed minimum quantity, in order to ensure the economic and financial equilibrium of the operator. They also provide for the annual adjustment of the royalty in the light of trends in the costs of staff, raw materials and maintenance work, and of an economic index. The agreements provide moreover for a renegotiation of the royalty if, owing to a change to the

\footnotetext{
${ }^{236}$ Point 33 of the Opinion of the Advocate General Kokott, delivered on 1 March 2005, C-458/03, Parking Brixen GmbH v Gemeinde Brixen and Stadtwerke Brixen AG, [2005] I-08585.

${ }^{237}$ Point 40, C-458/03, Parking Brixen GmbH v Gemeinde Brixen and Stadtwerke Brixen AG, [2005] I-08585.

${ }^{238}$ C-437/07, Commission of the European Communities v Italian Republic, [2008] I-00153.

${ }^{239}$ In this regard, see point 33, C-437/07, Commission of the European Communities $v$ Italian Republic, [2008] I-00153.

${ }^{240}$ Point 29, C-437/07, Commission of the European Communities v Italian Republic, [2008] I-00153. It is thereby cited point 34, C-382/05, Commission of the European Communities v Italian Republic, [2007] I-06657.

${ }^{241}$ Point 30, C-437/07, Commission of the European Communities v Italian Republic, [2008] I-00153. The following cases are cited: point 22, C-234/03, Contse SA, Vivisol Srl and Oxigen Salud SA v Instituto Nacional de Gestión Sanitaria (Ingesa), formerly Instituto Nacional de la Salud, [2005] I-09315 and points 35 and 37, C-382/05, Commission of the European Communities v Italian Republic, [2007] I-06657.

${ }^{242}$ Points 32 et ss., C-437/07, Commission of the European Communities v Italian Republic, [2008] I-00153.

${ }^{243}$ C-382/05, Commission of the European Communities v Italian Republic, [2007] I-06657. 
legislative framework, the operator is faced with investment above a certain level in order to comply with the new legislation. ${ }^{244}$

More recently, the CJEU seemed to have somehow reduced the emphasis on the operating risk that has to be borne by the concessionaire. The leading case can be considered Eurawasser. ${ }^{245}$ This case concerned the awarding of the water system by a number of German Municipalities. The issue regarded the fact that the risk entrusted to the private operator was very little. Users had, in fact, to be attached to the watering network and, in addition, there were charges fixed by the concessionaire in compliance with the existing laws. The CJEU once again remarked that the key feature of a concession contract is the concessionaire's remuneration, which consists of the right to manage the service in question. ${ }^{246}$ Therefore, the fact that 'the service provider is remunerated by payments from third parties, in this case from users of the service in question, is one means of exercising the right, granted to the provider, to exploit the service. ${ }^{247}$ By recalling the abovementioned Parking Brixen case, the CJEU held that the right to manage implies that the concessionaire 'takes the risk of operating the services in question. ${ }^{, 248}$ According to the Court's view, in certain sectors, because of the relevant public legal framework, the risk may be limited. Nonetheless, 'even if the risk run by the contracting authority is very limited, it is necessary that the contracting authority transfers to the concession holder all, or at least a significant share, of the operating risk which it faces, in order for a service concession to be found to exist. ${ }^{249}$

In the Acoset case, the CJEU reaffirmed the same considerations. ${ }^{250}$ That case concerned the award of the integrated water service management to an established 'semi- public company with share capital $[\ldots]$ predominantly publicly owned. ${ }^{251}$

Furthermore, the CJEU returned again on the issue in the Stadler case. ${ }^{252}$ This case regarded the award by a consortium of German Municipalities of the emergency ambulance service. The remuneration was agreed between the selected service provider and the social security institution. ${ }^{253}$ It was potentially re-adjustable if it ex post revealed to be insufficient. In addition, privately insured and uninsured persons were obliged to pay the same usage fee as persons insured under the

\footnotetext{
${ }^{244}$ Point 36, C-382/05, Commission of the European Communities v Italian Republic, [2007] I-06657.

245 C-206/08, Wasser und Abwasserzweckverband Gotha und Landkreisgemeinden (WAZV Gotha) v Eurawasser Aufbereitungs und Entsorgungsgesellschaft $\mathrm{mbH}$, [2009] I-08377.

${ }^{246}$ Points 50 et ss., C-206/08, Wasser und Abwasserzweckverband Gotha und Landkreisgemeinden (WAZV Gotha) v Eurawasser Aufbereitungs und Entsorgungsgesellschaft mbH, [2009] I-08377.

247 Point 53, C-206/08, Wasser und Abwasserzweckverband Gotha und Landkreisgemeinden (WAZV Gotha) v Eurawasser Aufbereitungs und Entsorgungsgesellschaft mbH, [2009] I-08377.

${ }^{248}$ Point 59, C-206/08, C-206/08, Wasser und Abwasserzweckverband Gotha und Landkreisgemeinden (WAZV Gotha) $v$ Eurawasser Aufbereitungs und Entsorgungsgesellschaft mbH, [2009] I-08377.

249 Point 77, CC-206/08, Wasser und Abwasserzweckverband Gotha und Landkreisgemeinden (WAZV Gotha) v Eurawasser Aufbereitungs und Entsorgungsgesellschaft mbH, [2009] I-08377. In this respect, see also point 31, C138/11, Compass-Datenbank GmbH v Republik Österreich, published in the electronic Reports of Cases (Court Reports - general), where the contract at stake was qualified as a concession because the concession holder was found to bear the 'commercial' risk of the service provision.

${ }^{250}$ See, for instance, point 39, C-196/08, Acoset SpA v Conferenza Sindaci e Presidenza Prov. Reg. ATO Idrico Ragusa and Others, [2009] I-09913.

${ }^{251}$ Point 17, C-196/08, Acoset SpA v Conferenza Sindaci e Presidenza Prov. Reg. ATO Idrico Ragusa and Others, [2009] I-09913.

${ }^{252}$ C-274/09, Privater Rettungsdienst und Krankentransport Stadler $v$ Zweckverband für Rettungsdienst und Feuerwehralarmierung Passau, [2011] I-01335.

${ }^{253}$ Point 12 C-274/09, Privater Rettungsdienst und Krankentransport Stadler v Zweckverband für Rettungsdienst und Feuerwehralarmierung Passau, [2011] I-01335.
} 
compulsory statutory scheme. ${ }^{254}$ The CJEU recalled the usual distinctive criterion between concessions and public contracts and insisted that the supplier is entitled to collect its payment from third parties as long as it bears the operating risk of the service in question. ${ }^{255}$ Thus, the Court considered that even if the remuneration comes from third parties - which do not have to necessarily be the service's users - the requirement of the right to manage is satisfied. ${ }^{256}$ For what concerns the operating risk, the CJEU reproduced the Eurawasser formula. ${ }^{257}$ Thus, 'while that risk may, at the outset, be very limited, it is necessary for classification as a service concession that the contracting authority transfer to the concession holder all or, at least, a significant share of the risk which it faces. ${ }^{258}$ The operating risk may be, therefore, limited only by the existing legal framework and not by contracting authorities. ${ }^{259}$ The Court further provided some important points clarifying the essential elements of the economic operating risk. First of all, such a risk must be understood as 'the risk of exposure to the vagaries of the market, which may consist in

(i) the risk of competition from other operators,

(ii) the risk that the supply of the services will not match demand,

(iii) the risk that those liable will be unable to pay for the services provided,

(iv) the risk that the costs of operating the service will not fully be met by revenue or

(v) for example also the risk of liability for harm or damage resulting from an inadequacy of the service.' 260

The Court then stated that, on the contrary, 'risks such as those linked to bad management or errors of judgment by the economic operator are not decisive for the purposes of classification as a public service contract or a service concession, since those risks are inherent in every contract, whether it be a public service contract or a service concession. ${ }^{261}$ Clearly, the CJEU requires that the concessionaire must bear market risks arising out of competition and, in any case, market variations. $^{262}$ In the case at stake, the Bavarian regime provided for the possibility of awarding an emergency service to competing private operators. Moreover, the system of fixing charges through

\footnotetext{
${ }^{254}$ Point 14, C-274/09, Privater Rettungsdienst und Krankentransport Stadler v Zweckverband für Rettungsdienst und Feuerwehralarmierung Passau, [2011] I-01335.

${ }^{255}$ Points 24 et ss., C-274/09, Privater Rettungsdienst und Krankentransport Stadler v Zweckverband für Rettungsdienst und Feuerwehralarmierung Passau, [2011] I-01335. Point 25 of the same judgment states that the fact that the supplier is not remunerated directly by the contracting authority, but is entitled to collect payment from third parties, meets the requirement of consideration laid down in Article 1, para 4, Directive 2004/18. However, point 26 specifies that it is also necessary that the service supplier takes the risk of operating the services in question.

${ }^{256}$ Point 28, C-274/09, Privater Rettungsdienst und Krankentransport Stadler v Zweckverband für Rettungsdienst und Feuerwehralarmierung Passau, [2011] I-01335.

${ }^{257}$ See the Eurawasser judjement, paragraphs 77 and 80.

${ }^{258}$ Point 29, C-274/09, Privater Rettungsdienst und Krankentransport Stadler v Zweckverband für Rettungsdienst und Feuerwehralarmierung Passau, [2011] I-01335.

${ }^{259}$ See points 34 et ss., C-274/09, Privater Rettungsdienst und Krankentransport Stadler $v$ Zweckverband für Rettungsdienst und Feuerwehralarmierung Passau, [2011] I-01335.

${ }^{260}$ See point 37, C-274/09, Privater Rettungsdienst und Krankentransport Stadler v Zweckverband für Rettungsdienst und Feuerwehralarmierung Passau, [2011] I-01335. In the same respect, see also point 48, C-348/10, Norma-A SIA and Dekom SIA v Latgales plānošanas Region, [2011] I-10983.

${ }^{261}$ Point 38, C-274/09, Privater Rettungsdienst und Krankentransport Stadler v Zweckverband für Rettungsdienst und Feuerwehralarmierung Passau, [2011] I-01335.

${ }^{262}$ Different kind of risk is the regulatory risk, which is not linked to the management. See, for instance, C-451/08, Helmut Müller GmbH v Bundesanstalt für Immobilienaufgaben, [2010] I-02673. 
negotiations led to low remuneration, which risked being not sufficient to cover all costs. In addition, Bavarian law did not guarantee full coverage of the operator's costs. ${ }^{263}$ Furthermore, the selected service provider was exposed to the risk of default of those liable for the usage fees. ${ }^{264}$

Overall, it can, thus, be held that the operating risk in the Stadler case was not precisely minimum. It was in any case higher than the one of the Eurawasser and Acoset cases. Anyhow, the CJEU seems now to be ready to accept a limited risk if such limitation arises out market conditions and not out contracting authorities' choices.

Notwithstanding the above, if there is no risk at all - because of an over-compensation of the concessionaire - the relationship must be qualified as a public contract and, as it was noticed, there could be an issue of illegal State aid. ${ }^{265}$ This, especially, if the award did not fully comply with a competitive procedure. $^{266}$

Therefore, concessions normally, but not necessarily, have a triangular structure where the involved end-users reimburse at least part of the costs borne by the concessionaire. However, not every triangular relationship is a concession. This depends on the existence of an operating risk. ${ }^{267}$ The fundamental and distinctive criterion between public contracts and concession contracts is, in fact, the existence of an operating risk transferred to the concession holder. ${ }^{268}$

To conclude, it can be mentioned the Eurostat decision entitled 'Treatment of public-private

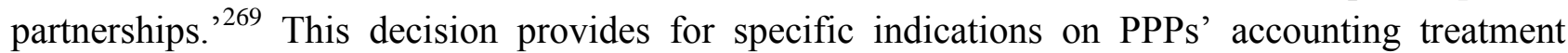
where the public sector is the main service purchaser. In order to define public debt, the registration of assets delivered through these transactions is off public budget only if there is a substantial transfer of risk to the private partner. This occurs only if the concessionaire bears the construction risk and at least one of the following risks: the availability or demand risk. ${ }^{270}$

\footnotetext{
${ }^{263}$ Point 42, C-274/09, Privater Rettungsdienst und Krankentransport Stadler v Zweckverband für Rettungsdienst und Feuerwehralarmierung Passau, [2011] I-01335.

${ }^{264}$ Point 46, C-274/09, Privater Rettungsdienst und Krankentransport Stadler v Zweckverband für Rettungsdienst und Feuerwehralarmierung Passau, [2011] I-01335.

${ }^{265} \mathrm{C}$ H Bovis, 'Financing services of general interest, public procurement and State aids: the delimitation between market forces and protection' [2005] European L Journ, 7 et ss. C H Bovis, 'Developing Public Procurement Regulation: Jurisprudence and its Influence on Law Making' [2006] Common Market L Rev 481 et ss..

${ }^{266}$ See point 95, C-280/00, Altmark Trans GmbH and Regierungspräsidium Magdeburg v Nahverkehrsgesellschaft Altmark GmbH, and Oberbundesanwalt beim Bundesverwaltungsgericht, [2003] I-07747. M E Comba, 'L'esecuzione delle opere pubbliche, con cenni di diritto comparato' in F G Scoca, F A Roversi Monaco, G Morbidelli (eds), Sistema del diritto Amministrativo Italiano, (Giappichelli, 2011) 7 et ss..

${ }^{267}$ See point 27 of the Opinion of Advocate General Szpunar delivered on 11 June 2015, C-552/13, Grupo Hospitalario Quirón SA v Departamento de Sanidad del Gobierno Vasco and Instituto de Religiosas Siervas de Jesús de la Caridad, not yet published (Court Reports - general). In this case, the selected economic operator collected its compensation directly from the contracting authority. However, it did not bear a substantial part of the operating risk related to the provision of the service in question. Thus, the contractual relationship had to be qualified as public contract.

${ }^{268}$ In this respect, see point 27, C-221/12, Belgacom NV v Interkommunale voor Teledistributie van het Gewest Antwerpen (INTEGAN) and others, published in the electronic Reports of Cases (Court Reports - general).

${ }^{269}$ Decision of February 11, 2004. In this respect, see Eurostat Treatment of Public-Private Partnerships Purposes, Methodology and Recent Trends, European PPP Expertise Centre, European Investment Bank, 2010, available at http://www.eib.org/epec/resources/epec-eurostat-statistical-treatment-of-ppps.pdf.

${ }^{270}$ The construction risk refers to events that may arise out the projecting and realization phases; the availability risk refers to the ability of providing the service in accordance with the agreed terms and quality standards; the demand risk refers to the variability of the demand and it is not linked to the quality of the provided service. See, among others, the Unità Tecnica Finanza di Progetto, Partenariato Pubblico-Privato per la realizzazione di opere pubbliche: impatto sulla contabilità nazionale e sul debito pubblico, Rome, June 30, 2001,7 et ss.. Eurostat decisions have a binding nature after the so-called third amendment introduced by the Legislative Decree n. 152/2008 to Article 3, para 15-ter of the former Code of Public Contracts.
}

61 


\section{Public-Private Partnerships in the selected Member States.}

\subsection{Introduction.}

The following paragraphs will provide a general overview of the PPP phenomenon as implemented in the Member States studied, namely the United Kingdom, the Netherlands and Italy, middle-high income and developed countries with a sufficiently established institutional set-up.

\subsubsection{The United Kingdom: general overview.}

The English Conservative Government of the early 1980s began to rethink the traditional in-house practice - especially at a central level - seeking to foster competition and promote efficiency in the delivery of public services and/or assets. Thus, a number of activities began to be privatised through the selling of Government businesses' shares while others were handed to independent Government agencies. Then, several services and works started to be contracted out. With regard to the activities still under the responsibility of the Government - or of Government agencies - it had to be previously verified whether they had to be carried out in-house or if it was better to contract them out to external suppliers. This control, referred to as 'market testing,' was normally undertaken through tendering procedures where the in-house bidder competed along with the private sector. ${ }^{271}$ Such a policy was later implemented at the central Government level by means of guidelines and administrative indications. At a local level, it became mandatory by law. The so-called Compulsory Competitive Tendering ${ }^{272}$ allowed local authorities to keep specific activities in-house exclusively when the in-house bidder won the bid by competing with other private bidders. In addition, this policy was further supported by the Deregulation and Contracting-out Act of 1994, which stated that specific Government functions could be transferred to private contracting parties.

In 1992, the then Chancellor of the Exchequer made an announcement on the 'ways to increase the scope for private financing of capital projects. ${ }^{273}$ This marked the beginning of what became known as the Private Finance Initiative (hereinafter PFI), under which private operators manage the design, build, finance and operation of public services and/or infrastructure. Besides the PFI scheme, the English Government developed other forms of private sector involvement in the delivery of public services and/or infrastructure generally referred to with the broader term of PPPs, which includes, inter alia, the PFI model. PPP is, in fact, an umbrella notion identifying several types of public-private cooperation schemes of public service and/or infrastructure delivery. The notion of PPPs includes, among others, the PFI, the creation of joint ventures established to carry out a certain service provision, the undertaking by private companies of development and regeneration projects and any kind of cooperative arrangement.

Since its introduction in 1992, the PFI became an important source of investment for the support of major capital project developments by various Government departments and local

\footnotetext{
${ }^{271}$ See, inter alia, S Arrowsmith, The Law of Public and Utilities Procurement: Regulation in the EU and UK (Sweet \& Maxwell, 2014) 32.

${ }^{272}$ For an analysis of the so-called CCT refer, among others, to J Wilson, 'Compulsory Competitive Tendering And Local Government Financial Services: An Analysis Of The Views Of Local Government Accountants In The North West Of England' [1999] Public Administration, Blackwell, 541, 563.

${ }^{273}$ Chancellor of the Exchequer Norman Lamont. See for instance, the House of Commons Treasury Committee' Report on Private Finance Initiative, Seventeenth Session 2010-12 available at http://www.publications.parliament.uk/pa/cm201012/cmselect/cmtreasy/1146/1146.pdf.

62
} 
authorities $^{274}$ and expanded significantly, especially under the 1997 Labour Government. However, this Government followed a less dogmatic approach. It did not a priori prefer the public or private service provision. It supported the contracting out policy only when it allowed the achievement of better VfM. ${ }^{275}$ The choice between the two models was, thus, made according to the delivery method that provided the same quantity and quality of a service or infrastructure at a lower overall cost. For instance, at a central level the contracting out policy was supported on a case-by-case basis, and specifically, if it was efficient, provided that an a priori investigation of the various options of service provision was carried out. ${ }^{276}$

Thus, since 1997 the PPP approach has been largely used in the UK. ${ }^{277}$ Private companies began to be broadly involved in public facilities' developments, including their designing, financing, construction, ownership and/or operation. At a local level, the best value approach made its way. On a case-by-case basis, local authorities had the possibility to choose the appropriate means of service provision. The Coalition Government that entered into power in 2010 upheld the PPP policy. Even though at a central level there were no rules such as the ones on the best value, Government departments and agencies were anyway expected to implement them. ${ }^{278}$
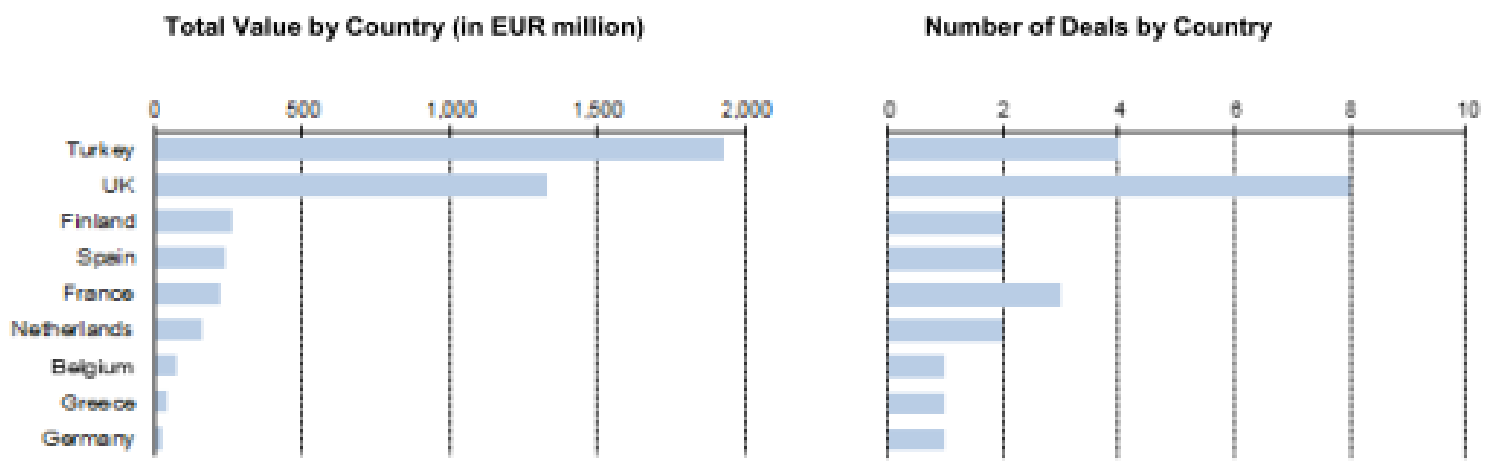

Fig. 2 Country breakdown by value and number of transactions.

\begin{abstract}
The period of reference is the first half of 2015. With 8 deals closed, the UK was the most active market by number of transactions. This is, however, less than the number of deals closed in the country over the same period in the previous 3 years (11, 12 and 16 in 2014, 2013 and 2012 respectively). In terms of numbers of deals, Turkey and France followed the UK.
\end{abstract}

Source EIB. $^{279}$

\footnotetext{
${ }^{274}$ T M Nisar, 'Implementation Constraints in Social Enterprise and Community Public-Private Partnerships' [2013] International Journal of Project Management, 638, 651.

${ }^{275}$ Value for money (VfM) can be defined as the optimum combination and balance of cost and quality that meets clients' needs. It is evaluated by comparing two or more alternatives for potential or actual results. HM Treasury, Value for money and the valuation of public sector assets, 2008, available at https://www.gov.uk/government/uploads/system/uploads/attachment_data/file/191488/Green_book_supplementary_gui dance_asset_valuation.pdf.

${ }^{276}$ See, inter alia, the Better Quality Services: Guidance for Senior Managers, TSO, 1998. Better Quality Services, A Handbook on Creating Public/Private Partnerships through Market Testing and Contracting Out, Cabinet Office, HM Government, 1998.

${ }^{277}$ See G M Winch, 'Institutional Reform in British construction: partnering and private finance' [2000] Building Research and Information, 141, 155.

${ }^{278}$ See the Best Value Statutory Guidance, Department for Communities and Local Government, 2011, available at https://www.gov.uk/government/uploads/system/uploads/attachment_data/file/5945/1976926.pdf.

${ }^{279}$ The study conducted is available at http://www.eib.org/epec/resources/publications/epec_market_update_2015_h1_en.pdf. 
Overall, the most important UK's outsourcing method and public-private arrangement is represented by the PFI scheme, introduced in the early 1990s by the Conservative Government. The reasons lying behind its introduction are the ambition for VfM in capital investment projects and the provision of public infrastructures maintaining a tight fiscal stance without raising taxes. PFIs allow costs to be spread over the life of the contract, instead, of being paid upfront. They also enable alternative sources of funds to be tapped. ${ }^{280}$ As already anticipated, the PFI is a way of outsourcing the provision of asset-intensive services. ${ }^{281}$ Specifically, PFI arrangements are long-term contracts under which the private party - normally a consortium of construction companies and funding entities - designs and builds infrastructure or provides a service, gets the needed funds, and then operates $\mathrm{it}^{282}$ over a period of time sufficient to recoup the costs of funding. This period is of usually of 25-30 years. During the entire contract life, the procuring public sector pays to the private party fees, thereby distributing its expenses over the entire service provision period. At times, the private party - in order to recover costs - obtains income, partially or entirely, from service end users.

PFI schemes were considered to have, in addition to the normal potential benefits of any other outsourcing method, areas of inherent advantages perceived as particularly important. These being, for instance, savings arising out one unique construction and operation phase, high opportunities for innovation in service delivery given that the private party is responsible for all the various stages of the project and great possibilities of allocating risks to the party better equipped to handle them. Moreover, the avoidance of waste, for instance in terms of spare asset capacity, was considered another potential benefit of the PFI scheme. In fact, the public party may not be able to effectively exploit them due to existing legal restrictions or practical limitations, such as lack of experience in that specific field. However, as in any contracting out method, attaining benefits is challenging and downsides are around the corner. For instance, the public sector borrowing is normally cheaper than the private sector's one. ${ }^{283}$ Therefore, PFI schemes had to outweigh the high financing costs borne by the private sector, recovering the investments made in order to obtain VfM.

As anticipated, the Labour Government from 1997 onwards supported the PFI policy, renamed as PPP policy. Later in 2010, with the Labour administration in power, PFI activities significantly increased if one considers the total level of investment, the amount of contracts procured and their overall value. ${ }^{284}$ This holds true even though in 2008 , the financial crisis drastically reduced the approval of funding and related procurements. ${ }^{285}$ The central Government procured many PPP contracts and funded administrations in order to have them doing the same.

\footnotetext{
${ }^{280}$ See, inter alia, Treasury Taskforce, Partnerships for Prosperity, The Private Finance Initiative, November 1997. Public-Private Partnerships: the Government's Approach, March 2000. HM Treasury, PFI: Meeting the Investment Challenge, July 2003, providing the Government's policy on the use of PFI available at http://webarchive.nationalarchives.gov.uk/20130129110402/http:/www.hm-treasury.gov.uk/media/F/7/PFI_604a.pdf.

${ }^{281}$ These is public infrastructure such as schools, hospitals, housing, roads, transports, prisons and waste disposals.

${ }^{282}$ This contract type is the so-called DBFO, design-build-fund and operate contract.

${ }^{283}$ M A Abramson, R S Harris, The Procurement Revolution (Rowman \& Littlefiled, 2003) 242. M Klein, Risk, Taxpayers and the Role of the Government in Project Finance (The World Bank, Private Sector Development Department, 1996) 3. H M Coombs, D E Jenkins, Public Sector Financial Management (Thomson, 2002$) 194$.

${ }^{284}$ See, inter alia, S Arrowsmith, The Law of Public and Utilities Procurement, Regulation in the EU and UK (Sweet \& Maxwell, 2014) 41.

${ }^{285}$ See N Timmins, PFI Projects seek Partners, Financial Times, 2009, available at https://www.ft.com/content/efe3c052-01e2-11de-8199-000077b07658. 
Thus, in many cases the PPP scheme became the only way to assure large investments in the delivery of public services and/or infrastructures. ${ }^{286}$

Nonetheless, in the UK there has been a large disagreement on the use and efficiency of PPP models. Several reports focusing on the PPP/PFI's trend were prepared directly by the Government or commissioned by it. ${ }^{287}$ For instance, the report of the House of Lords, Economic Affairs Committee, of March $2010^{288}$ positively remarked that PFI/PPP arrangements were normally more efficient than traditional procurement schemes in terms of on-time and on-budget delivery. Moreover, it highlighted that PPPs actually guaranteed VfM and overcame high financial costs. Nevertheless, it noted that more transparency in reporting public sector PPP liabilities was needed. In addition, improved commercial skills within the public sector were perceived as desirable in order to develop contract management abilities. Likewise, reliable data on whole life-cycle costs were needed to support a comparative and comprehensive investigation of the best risk allocation. In this respect, in the last years, the UK Government's goal has been to decrease public expenditure through the reduction of funding to its decentralized administrations for investment and infrastructure projects. ${ }^{289}$

Taking into account all the above considerations, on December 2012, the UK Government published a policy document entitled 'New Approach to Public Private Partnerships' (hereinafter 'the new approach'). The new approach represents the conclusions of the Government's 'Call for Evidence and review of PFI' and contains a revised version of the PFI scheme, the Private Finance 2 (hereinafter PF2). ${ }^{290}$ In this respect, the relevant HM Treasury publication highlighted that the Government

\begin{abstract}
'[...] remains committed to private sector involvement in delivering infrastructure and services, but has recognised the need to address the widespread concerns with Private Finance Initiative and the recent changes in the economic context.'
\end{abstract}

\footnotetext{
${ }^{286}$ House of Commons Treasury Committee, Private Finance Initiative, Seventeenth Report of Session 2010-12, available at http://www.publications.parliament.uk/pa/cm201012/cmselect/cmtreasy/1146/1146.pdf.

${ }^{287}$ For instance, the reviews of Sir Malcolm Bates, see

http://www.publications.parliament.uk/pa/cm199900/cmselect/cmtreasy/147/0012602.htm. HM Treasury, Modern Government: Modern Procurement, 1999, London, see

https://www.thenbs.com/PublicationIndex/documents/details?Pub=HMT\&DocID=248092. Treasury Reports 2003 and 2006 available at http://www.treasury.nsw.gov.au/Publications_Page/Financial_Reports\#2003-2004. National Audit Office Reports in 2003 and 2009 available at http://www.nao.org.uk/search/. Commission on Public Private Partnerships, Building Better Partnerships: The Final Report from the Commission on Public Private Partnerships, (Institute for Public Policy Research, 2001). A Pollock, J Shaoul, D Rowland, S Player, 'Public Services and the private sector: a response to the IPPR' [2001] Catalyst Working Paper, available at http://www.allysonpollock.com/wp-content/uploads/2013/04/Catalyst_2001_Pollock_PublicServicesPrivateSector.pdf. D Rowland, A M Pollock, 'Understanding the Private Finance Initiative: value for money?' [2003] Developments in Economics, 133, 48.

${ }^{288}$ House of Lords, Select Committee on Economic Affairs, $1^{\text {st }}$ report of Session 2009-10, Private Finance Projects and off balance sheet debt, March 17, 2010, available at http://www.publications.parliament.uk/pa/ld200910/ldselect/ldeconaf/63/63i.pdf.

${ }^{289}$ This in the light of the funding restrictions imposed by the fiscal policy addressing the deficit arising out the international economic crisis and the rescue of the banking sector.

${ }^{290}$ Details available at

https://www.gov.uk/government/uploads/system/uploads/attachment_data/file/205112/pf2_infrastructure_new_approac h_to_public_private_parnerships_051212.pdf. 
The main concerns with PFIs can be described as follows. Transfers of assets to the private sector may imply a loss of control and accountability by the public sector. Private sector providers need to make a profit while also having to pay higher finance charges than the public sector. The risk transfer to the private sector may result in an increase of costs for the private provider.

Bearing in mind these concerns, the new approach exploits PFIs' key advantages and introduces a number of changes that seek to eliminate waste, enhance efficiency and improve coordination between private and public parties to support the creation of new forms of partnerships capable of delivering better outputs. The new approach applies to all UK PF2 contracts, with the exception of ICT projects, ${ }^{291}$ and is it not suitable for projects with a capital value lower than $£ 50$ million.

The revised version of PFIs describes the approach to be taken when structuring PF2 contracts in order to achieve a better allocation of risks and a true understanding of the new model. The Standardisation of PF2 Contracts contains an explanatory text as well as draft provisions to be incorporated into PF2 contracts on either a required or a recommended basis. ${ }^{292}$ Changes of the required drafting have to be adequately reasoned in the light of project-specific needs. ${ }^{293}$ In addition, the PF2 approach seeks to fill in the standardisation's gap by providing, for instance, a new template for service outputs, a payment mechanism form and a model of shareholder's agreement. The public sector may anyway make changes to the standard drafting in order to deal with project-specific issues. Finally, the new PFI approach aims at reducing procurement time and costs by indicating a number of areas that - by following a standard path - can avoid extended negotiations.

Specifically, it provides for the possibility:

- for the Government, to be a minority public equity investor in a PF2 project,

- to limit the scope of private party's services,

- to allow flexible management of soft services by the public sector,

- to support transparency of operational and financial information on PF2 projects by not over relying on the private party's resources,

- to keep risks on the public sector's side where the latter proves to be more capable of managing them, and

- to enhance the involvement of private sector's investment by encouraging a variety of financing resources.

Thus, the PF2 approach sets out a new policy, procurement, VfM and contractual approach for the creation of a better public-private relationship and delivery of better results for the public sector and citizens.

As mentioned, among the key elements of the new approach, there is the reinforcement of the partnership. This is carried out through a higher public sector involvement. The latter, in fact,

\footnotetext{
${ }^{291}$ For ICT projects, see the Model Services Contract and Guidance available at https://www.gov.uk/government/publications/model-services-contract.

${ }^{292}$ See

https://www.gov.uk/government/uploads/system/uploads/attachment_data/file/207383/infrastructure_standardisation_of contracts_051212.PDF.

${ }^{293}$ Public authorities who need support with regard to the guidance must contact the competent Private Finance Unit and then HMT. Local authorities can ask advice from Local Partnerships, see http://localpartnerships.org.uk/. 66
} 
becomes a minority equity investor in PF2 projects, ${ }^{294}$ with the same - or similar - rights of the private party. In this regard, the new approach aims at aligning interests, supporting a better understanding of the project by both the parties involved. Moreover, projects' performance and ability to deal with risks is improved because the public sector is involved in strategic decisions. In addition, VfM is fostered because the public party can benefit from equity returns of successful projects and limit its overall project's costs. Furthermore, the new PF2 approach aims at extending equity sources by looking for and incentivising longer-term investors at an earlier stage. Several measures have also been set up in order to obtain greater results in terms of transparency and accountability of privately financed PPPs. Such measures, for instance, entail:

- the specification of ownerships details;

- records of costs and other payments (including those relating to the life cycle fund);

- records of building and operating manuals and service performance reports.

The HM Treasury is asked to publish details on the evaluation and approval phases of every PF2 project as well as an annual report with general information on every PF2 in which the Government is a shareholder.

Another main idea of the PF2 approach is to achieve better flexibility in the structure of PF2 contracts. This is pursued through a different range of measures. For instance, the number of services carried out by the private party is reduced to allow the economic operator to focus foremost on the management and maintenance of the PPP, while the contracting authority carries out soft services, such as catering or cleaning. Moreover, the private party is required to allocate in advance prices of minor maintenance activities in order to let the contracting authority decide whether to keep them in or outside the PF2 arrangement. Furthermore, annual efficiency reviews are required to control and enhance service deliveries and life-cycle reports are carried out to improve the effectiveness of life-cycle maintenance. The new approach focuses also on the creation of better risk allocation mechanisms within PF2 schemes. In this respect, the contracting authority is asked to manage a higher level of risk to improve VfM. For instance, it is the case of changes of insurance premiums or increased capital expenditures caused by unforeseen modifications of the law during the operational phase of the project.

Thus, overall the new PF2 approach aims at enhancing VfM for the public party and taxpayers through an increased market evaluation before the commencement of the procurement, public sector's equity, a more flexible service delivery, the use of mandatory projects' schedules and quicker and improved contracting authority's control processes. Lastly, the way has been opened up to a new guide on VfM assessment. ${ }^{295}$

\subsubsection{The Netherlands: general overview.}

The Netherlands PPPs' experience is quite recent, yet very interesting. The Publiek-Private Samenwerking (hereinafter PPS) was firstly used back in 1986 and its implementation began slowly and cautiously. Between 1986 and 1992, only two PPS were carried out and from 1993 onwards,

\footnotetext{
${ }^{294}$ A new independent Central Government Unit - within the HM Treasury - carries out public sector's investments.

${ }^{295}$ Which replaces the 2006 VfM Guide.
} 
PPS went through five years of - foremost public - hesitations and doubts. In fact, at the central level, the public sector had enough national budget to provide public services and/or infrastructure through traditional procurement means. Thus, PPS were considered as neither necessary nor worthwhile.

Roughly around 1999 a change occurred in the cultural and political arena. Specifically, the Ministries of Transport ${ }^{296}$ and Finance began to push forward the use of PPS as means of public services and/or infrastructure delivery. On the one hand, this change of attitude arose out the Ministry of Transport's need to downsize and reduce fixed costs in terms of personnel. For instance, cuts were undertaken at the Rijkswaterstaat ${ }^{297}$ In this perspective, PPS were seen as effective tools to tackle the need of public sector's internal re-structuring. In fact, PPS allowed extra tasks and risks to be outsourced to the private sector, thereby reducing the public sector's internal organization. On the other hand, the Ministry of Finance moved to a PPS support policy because of economic reasons. PPS allowed contracting authorities to pay private operators - for the provision of the public service and/or infrastructure - considerably after the contract awarding date, even after 25 years during the maintenance phase. Hence, as for PFIs, thanks to such payment mechanism, it was possible to invest public money, before the PPS payments, in other public initiatives and projects. In addition, PPS were perceived as potentially capable of fulfilling the Dutch Parliament's objectives. At that time, there was an urgent need to cope with high unemployment rates. The Dutch private business world was, in fact, lobbying, pushing the Government to deal with the issue of unemployment. Therefore, and within this picture, the Dutch Government decided to move towards a policy of strong PPS support promoting them as effective and viable tools in the delivery of public infrastructure and/or services throughout the Netherlands.

An increase in the use of PPS arrangements started from 2006 reaching a peak in 2012 when numerous PPS projects were launched. ${ }^{298}$ Specifically, the Ministry of Transport identified several projects that had to be carried out under PPS schemes. Along the lines of the above-mentioned political pressure coming from the Dutch Cabinet, a national PPS knowledge pool ${ }^{299}$ and centre ${ }^{300}$ were established, both at a national and local level. ${ }^{301}$ Moreover, specific training for civil servants was organized. The latter led to an improvement of public bodies' expertise on tendering and legal

\footnotetext{
296 Among others, it should be recalled that Mrs. Peijs, former Minister of Transport, played an important role in promoting the use of PPS throughout the country. At that time, the Ministry of Transport and Environment were separated. Today there is one unique Ministry of Environment and Infrastructure.

${ }^{297}$ Rijkswaterstaat is part of the Dutch Ministry of Infrastructure and the Environment and responsible for the design, construction, management and maintenance of the main infrastructure facilities in the Netherlands. These include: the main road networks, the main waterway network and water systems. Rijkswaterstaat manages the Netherlands' main highway and waterway networks. It is responsible not only for technical conditions of infrastructure but also for their user-friendliness. Smooth and safe traffic flows, a safe, clean and user-friendly national waterway system and protection from flooding. This is what Rijkswaterstaat aims at.

${ }^{298}$ An extensive list of PPS projects launched in the Netherlands can be found at http://www.ppsnetwerk.nl/Database1. However, some of them still have to go through the decision making phase.

${ }^{299}$ At a national level there is the Dutch PPP Unit that pools, develops and disseminates knowledge and expertise in the area of public-private partnerships, both within Rijkswaterstaat and the Ministry of Transport, Public Works and Water Management. The PPP Unit participates in various Rijkswaterstaat projects and maintains close connections with the private sector, other public authorities (including at national level) and international bodies. See, http://www.epppc.hu/netherlands.

${ }^{300}$ At a national level there is the Public-Private Partnership Knowledge Centre, see http://www2.vlaanderen.be/pps/english/index.html.

${ }^{301}$ At a local level there is the Europa Decentraal which is the local and regional authorities' premier knowledge centre, see http://www.europadecentraal.nl/english/.
} 
aspects related to PPS' structures and awards. Furthermore, the so-called Ruding ${ }^{302}$ Commission for Private Funding of Infrastructure was set-up in order to sustain and develop PPS. ${ }^{303}$ Besides the public sector's support, a positive consensus on the use of these instruments grew also within the private business world.

Today, at a national level, PPS are mostly used in big public infrastructures projects such as highways, ports, dams, tunnels and bridges. At a Province and Municipality level, PPS instead expanded mostly in the housing sector for the development, renovation and refurbishment of housing projects. This because the Dutch housing sector is typically a field where local public authorities have difficulties in creating effective relationships with the private sector. Private businesses, in fact, dominate the housing sector, as its main owners and controllers. Therefore, along with financial reasons, local public authorities at a Province or Municipality level, tend to turn to PPS schemes because PPS ease cooperation arrangements with private housing owners. With PPS, public and private parties collaborate, work together and play on the same level field. In addition, PPS are believed to be beneficial because of their capability of assuring a high overall quality level of projects, thanks, for instance, to the involvement of qualified experts.

Thus, in the NL, the main reasons that pushed forward the use of PPS models are, on the one hand, the increasing need for public services and/or infrastructure and, on the other hand, the private sector's unemployment. In addition, public sectors' organizational cuts, which led to smaller public bodies structures, increasingly made contracting authorities incapable of providing essential public infrastructure investments on their own.

As of today, the NL can count on standardized design, build, finance and maintain (hereinafter DBFM) contracts. ${ }^{304}$ Since 1999, the latter are, in fact, the main legal type through which PPS schemes are carried out. ${ }^{305}$ DBFM contracts represent an integrated approach under which the private sector normally shoulders design, financing, managing and maintenance risks. DBFM contracts are characterised by a high degree of freedom for the private partner especially in the project's planning phase. They are widely used because they allow the arrangement of several project aspects - such as, for instance, life-cycle considerations - within one unique contract. Hence, with DBFM contracts the public sector buys a complete and integrated performance, instead, of fragmented products or services. From the Dutch public authority's point of view, these contracts allow the provision of public infrastructure and/or services through a 'complete buying' scheme, whereby the private sector carries out all project phases, even the maintenance one, without the public sector having to organize or provide any of them. The economic operator generally receives periodical payments during the contract life. The payment mechanism is structured on an availability basis and on contractually agreed output specifications. Moreover, as these contracts entail the involvement of banks for financing aspects, high profile investment programmes can be funded and put forward.

\footnotetext{
${ }^{302}$ Former Minister of Finance of the Netherlands.

${ }^{303}$ Since February 2016, a specific division of the Ministry of Economic Affairs, PIANOo, carries out all PPS support tasks. See https://www.pianoo.nl/public-procurement-in-the-netherlands.

${ }^{304}$ The 4.1 standard form is the current applicable version. Full text available at https://www.rijksoverheid.nl/documenten/richtlijnen/2014/12/19/rijksbrede-modelovereenkomst-dbfm-infrastructuur2014.

${ }^{305}$ As in the case of the construction and reconstruction of the Second Coen Tunnel (DBFM contract); the construction and reconstruction of the A15 Maasvlakte-Vaanplein motorway (DBFM contract) and the motorway reconstruction A12 Utrecht-Veenendaal (DBFM contract). 
Central Government bodies opt for PPS arrangements after carrying out a comparison with other procurement forms. ${ }^{306}$ For accommodation projects with a value of over 25 million Euros and infrastructure projects of over 60 million Euros, such comparison is undertaken through the socalled added value test. The latter entails three major analyses. The first one is called market scan and it is normally carried out at the beginning of the planning phase. In fact, at an early stage, the public sector looks for the best VfM solution that economic operators can offer in terms of best balance between costs, time and quality. Therefore, the market scan allows the contracting authority to identify the private actor that could be involved in a certain project, how and when the latter should be carried out. ${ }^{307}$ However, it is used only for investment projects listed in the national multiyear programme of infrastructure projects. The second analysis is the Public-Private Comparator (hereinafter PPC), which is a tool that aims at verifying the extent to which a PPS arrangement will achieve VfM and, thus, if the PPS scheme represents the best contract option for the contracting authority. ${ }^{308}$ The PPC shows the financial advantages and disadvantages of different procurement methods for a given project. Political, environmental and/or social concerns are not taken into account. The PPC, in fact, requires only a financial comparison of life-cycle costs, gains and risks between traditional procurement models and PPS schemes. The PPC tool overall includes four modules:

- Module 1. An action plan describing the goal of the project, the major assumptions and differences between the contract types.

- Module 2. A qualitative analysis highlighting differences between the traditional procurement model and the PPS scheme. This analysis includes, for instance, risk allocation issues. The following are used as benchmarks: similar projects, literature, researches, experts' knowledge and an ad hoc check-list.

- Module 3. A quantitative analysis evaluating the differences emerged in Module 2. The outcomes of this analysis are calculated through the net present value method, which focuses on cash flows. ${ }^{309}$

- Module 4. The last module sums up what has been done in the previous Modules and offers concluding remarks. Advice is given on the best alternative (which is the one with the lowest net present value). This final report is very important for the contracting authority's final decision. Decisions not in accordance with the PPC outcome are allowed only if extensively reasoned and supported by the consensus of the Director

\footnotetext{
${ }^{306}$ In the NL, in fact, the central Government launches the large majority of PPS. In particular its agencies, namely the Rijkswaterstaat and the Rijksvastgoedbedrijf.

${ }^{307}$ This may be done by, for instance, attending trade fairs, reading trade journals and/or scanning suppliers' websites.

${ }^{308}$ A PPS is considered to generate VfM when the optimal combination of the whole life cycle costs and quality of an infrastructure or service is obtained and end users' requirements are met. HM Treasury, Value for Money Assessment Guidance, London, November 2006, available at

https://www.gov.uk/government/uploads/system/uploads/attachment_data/file/252858/vfm_assessmentguidance061006 opt.pdf.

${ }^{309}$ The net present value can be described as the difference between the present value of cash inflows and the present value of cash outflows. The net present value is used in capital budgeting to analyse the profitability of an investment or project. See, for instance, Rijkswaterstaat, Ministry of Infrastructure and Environment, Evaluating Value for Money, Auditing Public-Private Partnerships, The Work Continues, Seminar for Supreme Audit Institutions, 26 and 27 November 2012, The Hague, the Netherlands. 
General. Moreover, the Ministry of Transport regularly reports on PPC results to the Parliament.

For the purpose of a smooth PPC use, two standard documents, a handbook and checklist were elaborated. Moreover, qualified PPC experts of the Dutch PPS Unit offer their support. ${ }^{310}$ The PPC is normally carried out before the beginning of the tender or procurement phase.

The last analysis is the Public Sector Comparator (hereinafter PSC), which is generally undertaken at the beginning of the tender or procurement phase. The PSC compares the total lifecycle costs and risks of PPS and conventional procurement models. The Figure below shows how PPS phases are structured and when the market scan, the PPC and the PSC tools are usually carried out.

$$
\begin{array}{llll}
4 \text { to } 5 \text { years } & 1 \text { to } 2 \text { years } & 1 \text { to } 2 \text { years } & 20 \text { years } \\
\text { planning phase } & \text { tender phase } & \text { realisation } & \text { operation and maintenance phase }
\end{array}
$$

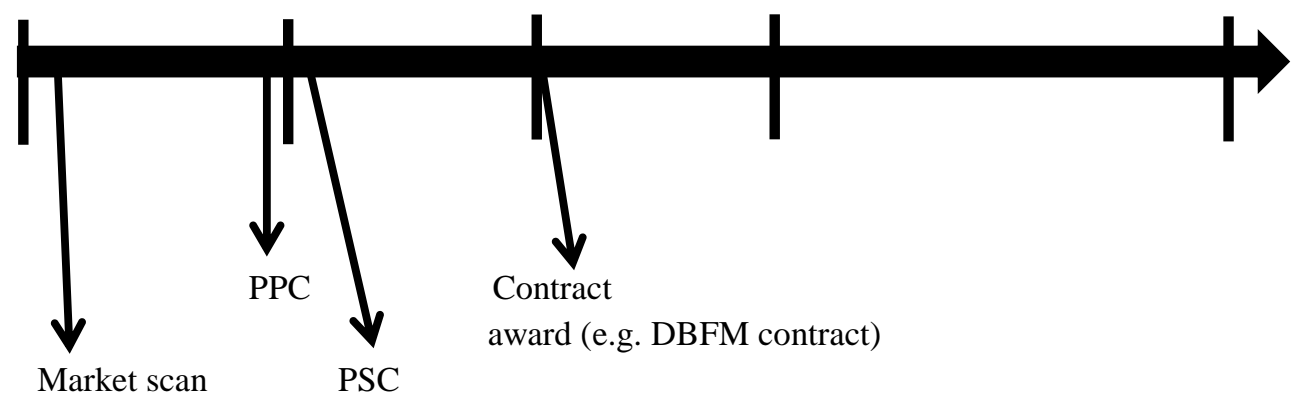

Fig. 3 PPS phases.

The DBFM option has shown so far to create an average added value of $10 \%$ to $15 \%$, if compared to projects carried out under conventional procurement schemes. ${ }^{311}$ Especially since 2013, the PPS market is progressively expanding and economic operators are increasingly willing to engage in these kind of arrangements. ${ }^{312}$ Moreover, as of today, several PPS projects in the housing and infrastructure sectors are in the pipeline $\mathrm{e}^{313}$ and more PPS projects are expected to be launched also by local authorities. ${ }^{314}$ Dutch PPS projects have increasingly proved to be delivered on time and within budget, especially thanks to the allocation of risks to the party that can better control them.

One of the major downfalls in the use of DBFM contracts in the NL arises out the abovementioned bank involvement in PPS structures. Banks, in fact, indeed play a crucial role in the realization of most public-private arrangements. However, because of their specific nature, they tend to avoid all those risks that may negatively affect contractors' revenues and cash inflows. Thus, for instance, banks usually do not look with favour to innovation, given its inherent high

\footnotetext{
${ }^{310}$ Further details are available at http://www.epppc.hu/netherlands.

311 J M Hebly, M Klijn, 'Public-Private partnerships in the Netherlands' [2016] EPPPL 46.

312 J M Hebly, M Klijn, Public-Private partnerships in the Netherlands', ibid., 47.

313 Details on the housing sector available at https://www.government.nl/topics/public-private-partnership-ppp-incentral-government/contents/housing-ppp-projects. Details on the infrastructure sector available at https://www.government.nl/topics/public-private-partnership-ppp-in-central-government/contents/ppp-infrastructureprojects.

${ }^{314}$ M Hebly, M Klijn, Public-Private partnerships in the Netherlands', op. cit., 48. 
degree of risk. In addition, banks are overall inflexible, while PPS models by nature need great flexibility in order to survive and effectively work. Besides banks, PPS difficulties may arise out the organization and management of the first two phases of the awarding procedure: the planning and tendering phases. The latter tend, in fact, to be very long. Together they can last up to seven years. Furthermore, given that once a PPS is awarded under a DBFM contract the contractor benefits of a situation of monopoly, project's changes - that may become necessary during the realization phase may be extremely costly and the public sector may not be able to cover such expenses. Moreover, the inflexible nature of the Dutch national budget represents another reason that can hinder PPS' full exploitation. Hence, a general call for more flexibility ${ }^{315}$ in both contract changes and budget availability should be brought forward for a smoother PPS' use in the NL.

Therefore, it can be overall stated that the PPS implementation in the NL was not a big-bang phenomenon. It, instead, slowly progressed through a step-by step process until expansion occurred. It could be argued that in the NL the number of PPS projects undertaken until today is low. However, if one considers that the NL is a relatively small country, this is not anymore true. Therefore, from this perspective, the number of PPS carried out in this country is quite high. ${ }^{316}$

As mentioned, several issues still hinder smooth PPS' implementation. For instance, a full understanding of PPS' financial added value, which is linked to a resistance towards DBFM contracts of some civil servants that consider them as complex arrangements from both a financial and legal point of view. In this regard, the public sector's tendering and legal expertise did improve in the last decades. However, its financial skills are still limited. In fact, the Dutch public sector usually hires external financial advisors from close neighbour Member States, such as France and Germany. Thus, after a full understanding of PPS' financial added value, it should be important to invest more on public servants' training, as this would help to move towards an out-put way of thinking and improve the formulation of functional specifications. Additionally, the PPS political commitment could be increased in order to assure a true boost of the PPS schemes as delivery means of public services and/or infrastructure. The mentioned issues inevitably hamper the use of PPS arrangements. Therefore, especially an evidence-based financial added value scheme for PPS models and a higher Government's awareness and support should be developed.

\subsubsection{Italy: general overview.}

The rise of PPPs is a quite recent phenomenon also in Italy. The first public-private transactions were carried out after the liberalization of the electric energy market at the beginning of the 1990s'. ${ }^{317}$ Then, in 1998, the so-called Merloni-ter Law introduced the public project-financing scheme and specific provisions on public work concessions became part of the national regulation of public contracts. ${ }^{318}$ These allowed a smoother award of public works to the private sector and their improved economic and functional management. In 1999, Law n. 144 established a specific PPP task force, namely the Unità Tecnica Finanza di Progetto, in support of the structuring and

\footnotetext{
315 The 2014 public procurement Directives aimed at responding to this call for greater flexibility.

${ }^{316}$ For instance, at a central level, respectively for the housing and infrastructure sector, see

https://www.government.nl/topics/public-private-partnership-ppp-in-central-government/contents/housing-ppp-projects and

https://www.government.nl/topics/public-private-partnership-ppp-in-central-government/contents/ppp-infrastructureprojects.

317 The Laws of January 9, 1991, n. 9 and n. 10 introduced the said liberalization.

${ }^{318}$ Law of November 18, 1998, n. 415. 
functioning of PPPs. ${ }^{319}$ From the year 2000 onwards a remarkable positive trend registered an increased use of PPP arrangements in the delivery of especially local public infrastructure and/or services. In fact, from 2000 to 2010 new rules on award procedures and contractors' selection were put into place. ${ }^{320}$ In addition, the general contractor scheme, ${ }^{321}$ the so-called appalto integrato ${ }^{322}$ and the locazione finanziaria immobiliare in costruendo ${ }^{323}$ entered into the Italian scenario as different legal types through which PPPs may take form.

The third amendment of the Italian Legislative Decree of April 12, 2006, n. 163 - the former Code of Public Contracts - provided for a legal definition of PPPs. ${ }^{324}$ However, it was a definition that did not indicate the distinctive features of the PPP category. It merely - and partially implemented EU law guidelines without providing any indication on the legal regime that governed the relationship between the private and public partners. ${ }^{325}$ The mentioned definition recalled, as a

319 The Unità Tecnica Finanza di Progetto was an ad hoc body established by Article 7 of the Italian Law n. 144/1999
within the Comitato Interministeriale per la Programmazione Economica, which is a Committee of the Department for
the planning and coordination of the economic policy set up by the central Government. However, Article 1, para 589,
of the Italian Law n. 208/2015 (so-called Legge di Stabilità 2016) eliminated the UTFP and transferred its competences
to the central Government Department for the planning and coordination of economic policy.
320 Among others, the Law n. 166 of August 1,2002 , widened the number of evaluating subjects including service
companies established by credit institutions registered within specific registries, eliminated the restriction of the
maximum duration of concessions (that was of 30 years) and of the maximum public funding (that was of the 50\%).
Moreover, in 2007 it was eliminated the right of the promoter to adequate its proposal to the bidder's one, hence resulting in the winner of the bid.

${ }^{321}$ The general contractor was introduced into the national legal system by the Law of December 21, 2001, n. 443, socalled Legge Obiettivo, that in order to streamline and speed up the implementation of strategic public works, authorized the Government to define the relevant discipline. Subsequently, the Decree of August 20, 2002, n. 190 (as amended by Legislative Decree n. 189/2002) outlined the nature and the operating procedural aspects of the general contractor through the provisions of Article 6 (procedures for the creation of infrastructure by the general contractor), Article 9 (reliance on general contractor) and Article 10 (procedure for awards to the general contractor), to which were added Articles of Chapter II-bis, on the qualification of the general contractors (Article 20-bis 20-j) introduced by the Legislative Decree n. 9/2005. The latter created a system of qualification of the general contractor of strategic works, different from the system of qualification of businesses that merely execute public works.

322 The introduction of the appalto integrato, which took place with Article 19 of the Merloni Law n. 109 of 1994, regulated public work contracts of special complexity whereby a single entity is entitled of both the designing and execution of a project. With the amending Decree (Legislative Decree n. 113/2007), the appalto integrato became applicable only to complex works of maintenance, refurbishment and archaeological excavations in bids below the European threshold awarded on the basis of preliminary projects, however, leaving it liberalized above the threshold. Article 53 was hence integrated by paragraph 3-bis. Later, there was the introduction of the new Regulation implementing the former Code of Public Contracts through the Presidential Decree of October 5, 2010 n. 207. This new legislation extended the scope of applicability of the appalto integrato to all works by breaking down the original distinction between design and execution.

${ }^{323}$ The so-called leasing in costruendo is a private funding scheme for public infrastructures' deliveries. It was initially regulated by the Law in 2007 and then incorporated into the former Code of Public Contracts (Legislative Decree n. 163/06, Article 160-bis), even if in a non-exhaustive way. It is a form of realization of public infrastructure where a financial entity anticipates to a private firm the funds that are needed to carry out a project. Once the asset is built, the private actor is repaid from the public sector with periodic reimbursements. It is an operation of structural finance where the funding aspect is connected to the construction of an asset in one unique tender procedure. Even though the public sector has a direct operative relationship with the service and maintenance providers, there is only one company responsible for the completion of the project, which will receive the reimbursement only when the infrastructure is completed and approved. The leasing in costruendo differs from project financing because it is not subject to economic and financial feasibility controls. In fact, cash flows deriving from the management of the asset in leasing do not have to repay the costs borne for its realization. Moreover, the leasing in costruendo provides that the management is carried out by the public sector after the payment of the reimbursement to the leasing company.

${ }^{324}$ Legislative Decree n. 152/2008.

${ }^{325}$ See Article 3, para 15-ter, Legislative Decree April 12, 2006, n. 163. PPPs are defined as contracts aiming at the execution of either the projecting, construction, management or maintenance of a public infrastructure or utility or the provision of a service, including in any case the total or partial funding of the private partner with a risk allocation that must follow the relevant Italian and EU provisions of law. 
way of example of PPP arrangements, concessions and financial leases, jointly held companies, and, under certain conditions, awards to a general contractor. ${ }^{326}$ The uncertainties arising out the wording of Article 3, para 15-ter of the former Code of Public Contracts were overcome with an interpretation that delimited the PPP category in the light of the criteria set out by the Commission in the 2004 Green Paper. Accordingly, traditional public procurement schemes did not fall within that definition of PPPs because of the absence of the long-term collaboration element recalled by the Commission. ${ }^{327}$ Concession contracts, instead, fell within the former Code of Public Contracts' definition of PPPs as the characteristics indicated in the 2004 EU document were met. Likewise, jointly held companies, recalled as well by Article 3, para 15-ter of the former Code of Public Contracts, were covered by the PPP notion especially because of the aspects related to the regulation of the private partner's activity, as highlighted by the Commission in the abovementioned Communication on IPPPs and by the CJEU in the Acoset judgement. ${ }^{328}$ Therefore, the common elements that allowed the legal identification of Italian PPP arrangements were the infrastructure and/or service management and the allocation of risks between the parties involved. $^{329}$

Within this picture and following a modification of the relationship between demand and offer, openness towards private contractors' financial participation and infrastructure management increased. ${ }^{330}$ The market started to focus on either big or small infrastructure and/or service provisions in new sectors, or better, in innovative markets. Thereby the boundaries between private and public assets, between works and services, became blurred and undefined. Since 2002, these new markets increased if compared to the entire public infrastructure and service market. Specifically, in 2002, there were 97\% traditional procurements, while ten years later, in 2011, the same value decreased to $74 \%$. Innovative markets, where PPPs - in their various forms - are mostly used, represent today $26 \%$ of the opportunities and $68 \%$ of transactions' value. ${ }^{331}$ The Osservatorio Nazionale del Partenariato Pubblico Privato ${ }^{332}$ showed that between 2002 and 2010 there has been a boost in the use of PPPs stimulated by increased reductions of public resources. ${ }^{333}$ However, this

\footnotetext{
${ }^{326}$ If the remuneration for the realization of the project is totally or partially postponed and linked to the availability of the goods to the public sector or end users.

${ }^{327}$ In this respect see, for instance, M P Chiti, Il partenariato pubblico-privato, concessioni, finanza di progetto, società miste, fondazioni (Editoriale scientifica, 2009) 5.

${ }^{328}$ C-196/08, Acoset SpA v Conferenza Sindaci e Presidenza Prov. Reg. ATO Idrico Ragusa and Others, [2009] I09913. The Commission in its IPPP Communication and the CJEU in the Acoset decision highlighted that the relevant aspects of this type of PPP are the selection of the private partner with regard to the clear delimitation of its managerial and technical contribution.

${ }^{329}$ In this respect, it can be mentioned that within the Italian regulation of project financing Article 153, para 13 has been added. The latter provides that from the beginning of the service execution, the private party has to provide a deposit that guarantees the penalties foreseen in case of breach or non-exact performance of every contractual obligation related to the management of the asset. In addition, the same Article states that not providing the said deposit represents a serious contractual breach.

${ }^{330}$ See 10 Anni di Partenariato Pubblico Privato in Italia, Sintesi, Project Financing, Osservatorio Nazionale, Cresme Europa Servizi, 2011, 2.

${ }^{331}$ Ibid., 3.

${ }^{332}$ The Osservatorio Nazionale del Partenariato Pubblico Privato is promoted by UTFP-CIPE, Dipartimento per la Programmazione e il Coordinamento della Politica Economica - Unità Tecnica Finanza di Progetto, ANCE Associazione Nazionale dei Costruttori Edili and it is run by CRESME Europa Servizi. See http://www.infoppp.it/.

${ }^{333}$ For instance, PPPs' awards between 2002 and 2010 have been 2.925 . From 83 awards in 2002 to 621 awards in 2010. 
increase was not linear nor constant and registered an intensification in 2009. In the last years, PPP percentages remained stable. ${ }^{334}$

In Italy, the most used and common forms of PPPs are public works and services concessions. The latter are more frequent, with 6.191 tenders in the period 2002-2010, representing 58\% of the whole PPP market. Nevertheless, service concessions are largely found in low value delivery projects. Public works concessions are, instead, less numerous, but generally have a higher economic value. ${ }^{335}$ They represent $76 \%$ of the national transaction' volume, for over 40 billion Euros. Furthermore, PPPs delivering so-called opere fredde are quite frequent in Italy. Opere fredde are public infrastructure and/or services with no end-users. Hence, where the private partner's 'client' is, entirely or partially, the public sector. It is the case of infrastructure or services that do not generate any cash inflow, such as schools, public offices or hospitals. On the public side, local Municipalities act as contracting authorities for several medium-sized infrastructure and/or service projects and play a key role in the use of PPPs. ${ }^{336}$ Central public authorities - even if still rarely focus, instead, on PPP arrangements with a higher overall value. PPPs are mostly used in the transport sector, followed by the water, gas and energy system fields, health and sport sectors, cemeteries and parking constructions and renovations of urban areas. ${ }^{337}$ In 2012, the PPP market registered an increase of $1.3 \%$ in terms of the number of initiatives, but a decrease of the economic value of projects of $48 \% .{ }^{338}$ The number of the 2012 PPP projects remained the same as in 2011, which is low if compared to the high values of the previous years - reached mainly because of the Italian Municipalities' boost in the use of PPPs. ${ }^{339}$ In 2014, the PPP market registered a $20 \%$ decrease of initiatives, from 370 tenders in 2013 to 297 in 2014. However, the economic value improved from 262 million Euros in 2013 to 489 million in 2014.

The use of PPPs has been further supported by the introduction, in 2016, of an ad hoc set of rules specifically dedicated to PPPs. In fact, on April 19, 2016, the Legislative Decree n. 50/2016, entered into force, repealed the former Code of Public Contracts ${ }^{340}$ and implemented Directives 2014/24/EU, 2014/23/EU and 2014/25/EU. The new Code re-organized the existing rules on public contracts for works, services and supplies, and notably introduced, for the first time in the Italian system, an ad hoc legal framework specifically devoted to PPPs. The latter preserved the fundamental rules already existing on PPPs and project financing provided by the Legislative Decree n. 163/2006, however, it specified concepts and introduced new provisions.

Part IV of the Legislative Decree n. 50/2016 - entirely dedicated to PPPs - first of all states that the rules of the new Code on general principles, EU thresholds, award procedures and concession contracts apply also to PPPs. Then, Article 180, Legislative Decree n. 50/2016, in order to deal with the uncertainties arising under the former Code, provides for a detailed definition of PPPs indicating their distinctive features. PPPs are defined as contracts for pecuniary interest,

\footnotetext{
${ }^{334}$ See among others, A Petretto, 'Partenariato pubblico-privato e finanziamento degli investimenti pubblici' in G C Feroni (ed), Il Partenariato pubblico-privato: modelli e strumenti, (Giappichelli, 2011) 145.

${ }_{335}$ Being more or less the $30 \%$ of the total PPP bids.

${ }^{336}$ There are figures showing an increase of PPPs' use by Municipalities from a $10 \%$ in 2002 to a $65 \%$ in 2011 in terms of economic value of projects and from $1 \%$ to $24 \%$ in the same years in terms of number of bids.

${ }^{337}$ For further data please refer to 10 Anni di Partenariato Pubblico Privato in Italia, op. cit., 15.

338 This occurred because of the 2011 public work concession of 2,7 billion Euros undertaken by the Autostrade del Lazio S.p.A. for the construction and management of the highway connecting Roma-Latina and Cisterna-Valmontone.

${ }^{339}$ In 2012 there have been 3.204 PPP bids for a value of 8,7 billion Euros. If compared to 2011 the PPP demand increased of $13 \%$ while decreased for value of $35 \%$.

${ }^{340}$ Legislative Decree n. 163/2006. 
concluded in writing, under which one or more contracting authorities give to one or more economic operators, for a specified period and depending on the time needed to recoup the investment made, or on the specific financing mechanism, a number of activities consisting in the:

- realization,

- transformation,

- maintenance, and

- operational management

of an infrastructure in exchange for its availability, economic exploitation, or supply of a service related to its use. Moreover, the Code specifies that in PPP contracts the private operator bears a set of risks according to what is provided by the relevant contract. ${ }^{341}$ Article 180, Legislative Decree $n$. $50 / 2016$, further states that economic operators' revenues consist of fees paid by the public partner, or by any other form of economic consideration, including direct earnings arising out the management of the service or infrastructure. Article 180, para 3, holds that in PPPs risks transfers to the economic operator entail the allocation to the latter of the construction and availability risk or, in cases of profitable projects with respect to third parties, the demand risk for the service delivered during the management period. The recovery of the investments made and of the costs borne by the economic operator depends:

- on the actual delivery of the service, or

- on the availability of the infrastructure, or

- on the volume of service provided with respect to the demand, and

- in any case, if the service or infrastructure complies with the quality levels provided by the contract.

Upon the availability of the infrastructure or demand of the service, the contracting authority may choose to pay a fee, which is proportionally reduced or cancelled in the case of low or nonavailability of the infrastructure, of reduced or non-provision of the services. Such fee modifications must negatively affect the net present value of all investments, costs and revenues of the economic operator. The contracting authority may also choose, upon availability of the infrastructure or demand of the service, to pay a different fee or that the remuneration of the service depends on the direct exploitation of the asset by the economic operator, which, hence, bears the risks of the negative fluctuations of the service's demand. Para 6 of the same Article states that the economic and financial equilibrium is the prerequisite for a proper allocation of risks in PPP contracts. ${ }^{342}$ Para 8 , instead, indicates which are the contracts falling within the notion of PPPs. These are project financing, construction and management concessions, service concessions, financial leases, the contratto di disponibilità as well as any other form of partnership - for the realization of works or services - which meets the characteristics specified under Article 180, Legislative Decree n. 50/2016.

Furthermore, Article 181, Legislative Decree n. 50/2016, holds that the selection of economic operators must be carried out through a public tender procedure. The legislator expressly indicated -

\footnotetext{
${ }^{341}$ Article 3, para 1, letter eee), Code of Public Contracts.

342 The economic and financial equilibrium is defined by Article 3, para 1, letter fff), Code of Public Contracts. 76
} 
as its preferred choice - the competitive dialogue. Article 182, Legislative Decree n. 50/2016, instead, states that the financing of PPP contracts may be carried out using any adequate tool including, among others, project-financing schemes. ${ }^{343}$ The PPP contract must indicate risks transferred, monitoring systems and consequences resulting from an early termination of the contract. Article 184, Code of Public Contracts, further states that a call for tender for the award of a concession for the construction and/or management of an infrastructure or service must foresee the possibility for the contractor to establish a project company, namely a SPV. The project company, by taking over the concession agreement, becomes the concessionaire. Moreover, on financing aspects of PPP contracts, Article 185, Legislative Decree n. 50/2016, provides for the possibility for SPVs, and companies awarded with a PPP contract, to issue bonds and debt securities, to be subscribed by qualified investors, for the realization of a public infrastructure or delivery of a public service. Article 185, para 3, states that the aforementioned bonds and debt securities may be secured by the financial system, private foundations and funds.

Article 187, Legislative Decree n. 50/2016, holds that contracting authorities may also resort to a financial lease for the construction, acquisition and completion of a public infrastructure or service. A financial lease is considered a works contract unless works are merely incidental with respect to the main object of the contract. The following Article 188 regulates, instead, the contratto di disponibilità. Under this contract, the contractor is paid with an availability fee upon the actual availability of the infrastructure, which is proportionally reduced or cancelled in the event of reduced or non-availability. A payment may be also recognized to the economic operator - when works are in progress - in case of transfer to the contracting authority of the ownership of the infrastructure. In any case, the private party shoulders construction and technical management risks and the relevant contract defines the risks' distribution. The provisions set out in the Legislative Decree n. 50/2016 on general requirements for the participation to procurement procedures and qualification of economic operators apply also to the contratto di disponibilità. In addition, Article 191, Legislative Decree n. 50/2016, provides that a call for tender may foresee by way of consideration - partial or total - the transfer to the private party of the ownership of an immovable property belonging to the contracting authority.

Title II, Part IV of the Legislative Decree n. 50/2016, also regulates the special regime of inhouse awards. It provides that in-house awards of contracts relating to services available on the market in a competitive regime require a prior evaluation of the economic adequacy of the offers. Particular attention has to be put on the benefits achievable for the community through the chosen management form.

Article 193, Legislative Decree n. 50/2016, then provides that if for the best use of an infrastructure a coordinated action of several public entities is required, such entities may sign a program agreement and, if necessary, establish a public project company. The latter carries out the project on behalf of its shareholders and makes use of an ad hoc funding scheme. Chambers of commerce, industry and crafts as well as banking foundations may participate in this kind of project companies.

Title II, Part IV of the Legislative Decree n. 50/2016, finally, regulates awards to general contractors. Under these kind of contracts, the contracting authority entrusts to an economic

\footnotetext{
${ }^{343}$ Article 183, Legislative Decree n. 50/2016, provides for a detailed regulation specifically dedicated to project financing. See, among others, M Nicolai, W Tortorella, Partenariato Pubblico Privato e Project Finance (Maggioli Editore, 2016). 
operator with an adequate organizational, technical and financial capacity the realization, by any means, of a project against a consideration paid, in whole or in part, after the completion of the works. The general contractor prepares the final design project, the works' plan, the financing, the management plan and the managers' selection. The contracting authority approves the design project and carries out works' testing. The general contractor is liable to the contracting authority for the proper and timely execution of works, which may be performed directly, through a project company or by third parties.

Notwithstanding the above-mentioned new legal framework that now regulates and supports PPP arrangements, there are still a number of critical concerns affecting an effective use of PPPs in Italy. As of today, the main issues that hinder the effectiveness of public-private transactions are the use of PPPs especially for medium-sized projects, the fragmentation - and often lack - of contracting authorities' expertise and a poor competitive pressure. The latter mainly arises out of the little innovative capacity and specialization of companies and issues related to high taxation and low incentives. Moreover, critical aspects originate from the long period of time that normally separates the award of contracts and their financial close as well as the use of PPPs as elusive means of public finance restrictive measures. ${ }^{344}$ In this latter respect, PPPs may be used to avoid the constraints imposed by fiscal rules on public investment. In fact, by resorting to PPPs, the public sector may formally comply with the relevant fiscal regime, as no upfront public spending is needed. However, the elusion may occur because public spending is only postponed to a future moment, namely at the end of or during the contract life. Lastly, the following aspects affect a full implementation of PPPs in Italy. The potential inadequacy of certain financial feasibility plans, the difficulties related to the possibility of obtaining bank loans and the complexity of the relevant broader national legal framework.

\section{Conclusions to this Chapter.}

This Chapter investigated the nature and features of the PPP category by firstly discussing its understanding at an International and European level in order to later identify the main goals pursued through these arrangements. Then, the focus was put on PPPs' legal background at an International and European level. At an International level, the discussion concentrated on PPPs' best practices developed in the last decades between international market actors. At a European level, the attention was put on the relevant Treaty principles and public contracts and concessions law provisions. Moreover, this Chapter highlighted the elaboration of the PPP phenomenon made by the EU Institutions, particularly by the Commission. Furthermore, it focused on the relevance of the EU public procurement Directives, in particular, of the 2014 Directive on the award of concession contracts. An overview of the importance of the operating risk element in the 'concession' notion, as explained by the CJEU case law, was presented. The second part of this Chapter was devoted to the investigation of PPPs' implementation in the Member States studied, namely the UK, the NL and Italy. For each jurisdiction, specific aspects were highlighted: (i) the Government support in the promotion of PPPs, (ii) PPPs types most commonly used and the sectors in which they progressed, (iii) the relevant legal framework and (iv) the main criticalities connected to their use.

\footnotetext{
${ }^{344}$ See, Dipartimento per la Programmazione e il Coordinamento della Politica Economica, Unità Tecnica Finanza di Progetto, Partenariato pubblico-privato in Italia, Stato dell'arte, futuro, proposte, 2010. 
The study of the PPP phenomenon - both in general terms and as implemented in the Member States studied - along with a review of its legal framework represents the necessary starting point of this thesis. As seen, PPPs cannot rely on an ad hoc regulation specifically dedicated to them, neither at EU nor at an International level. Therefore, Chapter II served the purpose of identifying the International and EU legal regime governing PPPs. At the same time, it highlighted the set of rules that will be analysed in the following Chapters in order to explore the current legal spaces recognised - within these kind of complex public contracts - to sustainable development considerations.

With specific regard to the PPP phenomenon, this preliminary study showed that PPPs entail a different approach to procuring public infrastructure and services from traditional public procurement means. PPPs present a particular set of inherent features, which may range from enhanced feasibility and preliminary studies, public monitoring, long duration, applicability in strategic priority fields, to the need of a sector wide strategy and a policy framework to support them. In this respect, the public sector plays a key role in ensuring the projects' implementation and prompt responses in cases of changes or conflicts, which can in turn avoid potential disputes. PPPs represent an important delivery form of public infrastructure and services re-emerged in the last decades. The PPP phenomenon can count on several different formalizations: numerous legal options, types, structures and strategies are available. The PPP market and the risks that parties are willing to accept vary from place to place and from project to project. PPPs are often described as legal arrangements lying somewhere between public provision and privatization. In fact, until recently, public services and infrastructure facilities were considered to be public goods, hence, they were built by the public sector, financed by taxpayers and managed by public entities. It was more or less in the 1990s that several jurisdictions began to resort to PPPs. These arrangements link together finance, construction and operation into one single long-term contract between the contracting authority and a private company. During the contract life, the private sector receives a set of revenues as compensation for the first investment, operational costs and maintenance expenses. Depending on the contract type chosen, the set of incomes may be users' fees, payments from the contracting authority or a combination of both. At the end of the contract, the asset may be transferred to the public sector.

The importance of PPPs will most likely continue to increase, although at times also for wrong reasons and in the wrong ways. It is, for instance, the case of PPPs used to elude public finance restrictions or to pursue exclusively profitable objectives without considering the related socio-environmental impacts. Therefore, given the erroneous directions toward which PPPs may be oriented, the potentialities of PPPs in the promotion - along with economic concerns - of socioenvironmental benefits will be investigated. To this end, the following Chapters will explore the legal means though which PPPs can act as true and effective public delivery options from a sustainable development point of view. Thus, it will be studied the scope for welfare and environmental considerations gains within PPPs' structures, given that the typical features of public-private relationships indeed allow room for opportunism in this respect. Especially in complex infrastructure and service projects, PPPs have the potential to play an important and positive role in the promotion of sustainable development goals. Therefore, moving from the current state of the art on the PPP phenomenon - which had to be dealt with - it is worthwhile to study the current legal spaces for social and environmental considerations that can be located within PPPs' structures. 
Unsurprisingly, as PPPs spread throughout the globe during the last decades, PPPs' practice went a long way ahead of a clear understanding and acknowledgment of their potential broader implications. Governments and private actors took advantage of the opportunities offered by PPP schemes - especially from an economic perspective - to advance their own specific interests and agendas. Thus, today more than ever, it is important to move towards a smarter PPPs' understanding, use and governance, whereby also social and environmental considerations are fully embraced. 


\section{CHAPTER - PUBLIC-PRIVATE PARTNERSHIPS AND SUSTAINABLE DEVELOPMENT IN THE EUROPEAN UNION}

\section{The concept of sustainable development.}

There are many definitions of sustainable development. ${ }^{1}$ It is a broad and abstract concept, ${ }^{2}$ which brings together various meanings that are often understood differently among individuals, professionals, interest groups, State agencies, political leaders and NGOs. ${ }^{3}$ In this thesis, the term sustainable development will refer to a particular vision of growth where social, economic and environmental considerations are integrated with one another as inseparable and interdependent components of human progress. In this respect, probably the most renowned definition of sustainable development, explains well such understanding. In 1987, the World Commission on Environment and Development ${ }^{4}$ defined sustainable development as a 'development that meets the needs of the present without compromising the ability of future generations to meet their own.' In other words, sustainable development is endorsed when the needs of the present generations are met, while the possibility for future generations to meet their own is not put at risk. This can occur only if an effective balance between economic, social and environmental objectives is found.

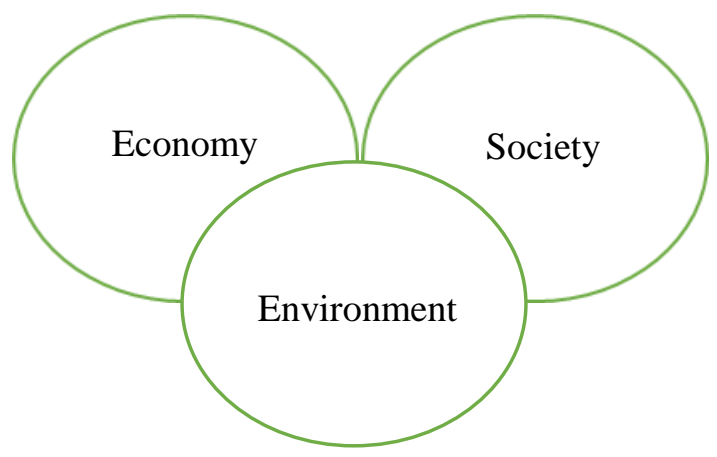

Fig. 4

The concept of sustainable development.

\footnotetext{
${ }^{1}$ D C Dragos, B Neamtu, 'Sustainable Public Procurement in the EU: Experiences and Prospects' in F Lichère, R Caranta, S Treumer (eds), Modernising Public Procurement: the New Directive (DJØF, 2014), 302.

2 B J Brown et all, 'Global Sustainability: Toward Definition' [1987] Environmental Management, 713, 719. C Kidd, 'The Evolution of Sustainability' [1992] Journal of Agricultural and Environmental Ethics, 1, 26.

${ }^{3}$ S Arrowsmith, P Kunzlik, 'Public Procurement and Horizontal Policies in EC Law: General Principles' in S Arrowsmith and P Kunzlik (eds), Social and Environmental Policies in EC Procurement Law (Cambridge University Press, 2009) 35. M Comba, 'Green and Social Considerations in Public Procurement Contracts: A Comparative Approach' in R Caranta and M Trybus (eds), The Law of Green and Social Procurements in Europe (DJØF, 2010$) 307$. K Portney, Taking Sustainable Cities Seriously, (MIT Press, 2003). P Selman, Local Sustainability: Managing and Planning Ecologically Sound Places (St. Martin's Press, 1996). J Zachary, Sustainable Community Indicators: Guideposts for Local Planning (Wiley, 1999).

${ }^{4}$ The so-called Brundtland Commission. World Commission on Environment and Development, From One Earth to One World: An Overview (Oxford University Press, 1987).
} 
On the one hand, it can be argued that - especially in the short term - these objectives are in conflict with one another. On the other hand, by looking at the bigger picture and with a long-term perspective, economic, social and environmental targets are capable of advancing simultaneously and progressing together. Therefore, economic growth goals can, for instance, be pursued along with environmental objectives. The latter view is the one embraced by this thesis: the concept of sustainable development as the establishment of a synergy between the economic, environmental and social dimensions of human life in order to move towards a new approach of human progress.

The principle of sustainable development emerged in the early $1970^{5}$ in order to counteract modern development practices, which were bringing worldwide environmental and social crises. ${ }^{6}$ It became a fundamental objective of the EU in 1997 when the Treaty of Amsterdam included it as an over-reaching goal of EU policies. ${ }^{7}$ On June 2001, at the Gothenburg Summit, the first EU sustainable development strategy was launched. ${ }^{8}$ Objectives and policy measures were set out in order to deal with unsustainable trends. A new approach to policy-making was invoked to ensure that the EU's economic, environmental and social policies mutually support each other. The EU sustainable development strategy added a third environmental dimension to the Lisbon strategy ${ }^{9}$ and aimed at identifying actions allowing the EU to obtain an enduring, long-term improvement of quality of life. This, through an effective management and use of resources capable of tapping economic growth, environmental protection and social cohesion. It asked the Commission to refer every new policy proposal to an impact assessment. ${ }^{10}$ The outcomes of the Gothenburg Summit form the basis of EU's policies towards sustainable development, along with other commitments such as those taken at the 2002 World Summit on sustainable development in Johannesburg ${ }^{11}$ and the 2000 Millennium Development Goals. ${ }^{12}$

Later in 2005, guiding principles on sustainable development were adopted ${ }^{13}$ and a proposal for a reviewed strategy was put forward by the Commission in order to take further action. This proposal moved from the 2001 strategy and called for a stronger shift in focus. The outcome was a new strategy that concentrated on the means available to the EU to pursue its long lasting

\footnotetext{
${ }^{5}$ It is a principle that was developed and elaborated already in the 1970 s. However, only with the Treaty of Amsterdam did it become part of the EU Treaty. Later it was sealed within the Charter of Fundamental rights of the European Union.

${ }^{6}$ S M Wheeler, Planning for Sustainability. Creating Liveable, Equitable, and Ecological Communities (Routledge, 2004) 19.

${ }^{7}$ Articles 1 and 2 of the Treaty of Amsterdam. At the International Level, see the first UN Conference on Environment and Development held in Rio in 1992. This conference represented one of the first commitments towards sustainable development. At the summit, a program of action for sustainable development was adopter, namely Agenda 21, Chapter 4.23 .

${ }^{8}$ Commission Communication of 15 May 2001, 'A Sustainable Europe for a Better World: A European Union Strategy for Sustainable Development' Commission proposal to the Gothenburg European Council, COM (2001) 264 final - not published in the Official Journal.

9 The Lisbon strategy, or Lisbon Agenda or Process, was an action plan for the development of the EU economy between 2000 and 2010 .

${ }^{10}$ See http://ec.europa.eu/smart-regulation/impact/index_en.htm.

${ }^{11}$ Plan of Implementation, Chapter 3, paras 15 and 19 letter c), available at http://www.un.org/esa/sustdev/documents/WSSD_POI_PD/English/WSSD_PlanImpl.pdf.

${ }_{12}$ Data available at http://www.undp.org/content/undp/en/home/sdgoverview.html.

${ }^{13}$ See the Communication from the Commission to the Council and the European Parliament, Draft Declaration on Guiding Principles for Sustainable Development, Brussels, 25.5.2005, COM (2005) 218, final. Also, the Commission Communication of 9 February 2005, 'The 2005 Review of the EU Sustainable Development Strategy: Initial Stocktaking and Future Orientations' [COM (2005) 37 final - not published in the Official Journal].
} 
sustainable development targets. ${ }^{14}$ The focus was put on the need to replace the current consumption and production attitude with a sustainable and integrated approach. Since 2007, the Commission prepares every two years a report on the implementation progress of the sustainable development strategy. ${ }^{15}$ Member States and Eurostat regularly elaborate sustainable development indicators. $^{16}$ Specifically, Eurostat carries out bi-annual monitoring reports on sustainable development in the EU. In 2009, the EU Council remarked that sustainable development remains a fundamental objective of the EU under the Lisbon Treaty. Thus, such a principle became part of a broad range of EU policies. ${ }^{17}$ In 2010, the European Union launched its ten-year jobs and growth strategy, Europe 2020, which aims at promoting a smart, sustainable and inclusive growth throughout the EU. ${ }^{18}$ In 2011, the Commission Communication 'Rio+20: towards the green economy and better governance' dedicated specific attention to sustainable development. ${ }^{19}$ In addition, in 2012, Member States - moving from the Millennium Development Goals - launched another process to develop a renewed set of sustainable development goals. ${ }^{20}$

\section{Sustainable public procurement.}

Sustainable development is a principle that can guide many different choices. This acknowledgment became part of a general EU call for specific actions in support of sustainable development objectives. ${ }^{21}$ Sustainability had to be secured through the adoption of policy measures that included sustainable development considerations. Within this picture, a transition towards sustainable production and consumption was advocated. Thus, public procurement began to be perceived as an effective tool through which sustainable development goals could be positively encouraged. ${ }^{22}$

Traditionally, the main goal of public procurement has been economic efficiency, with little attention put on non-economic considerations. ${ }^{23}$ The 1990 s began, however, to register a reduction

\footnotetext{
${ }^{14}$ Communication from the Commission to the Council and the European Parliament on the Review of the Sustainable Development Strategy, A Platform for Action, Brussels, 13.12.2005 COM (2005) 658, final.

${ }^{15}$ The Commission adopted in 2007 the first progress report, which is available at http://eur-lex.europa.eu/legalcontent/EN/TXT/PDF/?uri=CELEX:52007DC0642\&from=EN. Commission Communication of 22 October 2007 'Progress Report on the Sustainable Development Strategy 2007' [COM (2007) 642 final - not published in the Official Journal].

${ }^{16}$ Sustainable development indicators to monitor the implementation of the EU sustainable development strategy [SEC (2005) 161 - not published in the Official Journal]. Further data available at http://ec.europa.eu/eurostat/statisticsexplained/index.php/Main_Page.

${ }^{17}$ In this respect see, for instance, the Communication from the Commission to the European Parliament, the Council, the European Economic and Social Committee and the Committee of the Regions of 24 July 2009, Mainstreaming sustainable development into EU policies: 2009 Review of the European Union Strategy for Sustainable Development [COM (2009) 400 final - Not published in the Official Journal].

${ }^{18}$ Further details on priorities, targets and initiatives available at http://ec.europa.eu/europe2020/europe-2020-in-anutshell/index_en.htm.

${ }^{19}$ Communication from the Commission to the European Parliament, the Council, the European Economic and Social Committee and the Committee of the Regions, Rio+20: Towards the Green Economy and Better Governance, Brussels, 20.6.2011 COM (2011) 363 final, 2, 4, 8, 9, 10, 13, 14 .

${ }^{20}$ At the UN Conference on sustainable development the focus was on (a) the green economy and (b) the institutional framework for sustainable development. Further details are available at http://www.uncsd2012.org/about.html\#sthash.gt9fepQG.dpuf.

${ }^{21}$ For instance, in 2007, the EU Council stressed the need to prioritise sustainable development implementation measures. See the Presidency Conclusions, Brussels, December 14, 2007, 16, available at http://www.consilium.europa.eu/ueDocs/cms_Data/docs/pressData/en/ec/97669.pdf.

${ }^{22}$ B Sjafjell, A Wiesbrock, 'Why should Public Procurement be about Sustainability?' in B Sjafjell, A Wiesbrock (eds), Sustainable Public Procurement Under EU Law (Cambridge University Press, 2016) 1, 22.

${ }^{23}$ D C Dragos, B Neamtu, 'Sustainable Public Procurement in the EU: Experiences and Prospects', op. cit., 301. 83
} 
in the use of public procurement only to attain policy objectives linked to the Internal Market and competition considerations. $^{24}$ Thereafter, the widespread call for sustainable development promotion, increasingly led the public sector to use its purchasing power to uphold sustainable development targets. As a result, sustainable public procurement - as a specific form of development - grew in terms of endorsement and implementation. Today, contracting authorities have to respect general sustainable development obligations as well as specific targets concerning, for instance, energy use. ${ }^{25}$ Public procurement is now seen as an essential contributor to the achievement of sustainable development objectives representing an effective and concrete policy measure through which governments can pursue socially and environmentally responsible practises through the use of public contracts. ${ }^{26}$

Sustainable public procurement has been defined in many ways. Among all, it has been defined as 'a process whereby public organizations meet their needs for goods, services, works and utilities in a way that achieves value for money on a whole life cycle basis in terms of generating benefits not only to the organization, but also to society and the economy, whilst significantly reducing negative impacts on the environment'. ${ }^{27}$

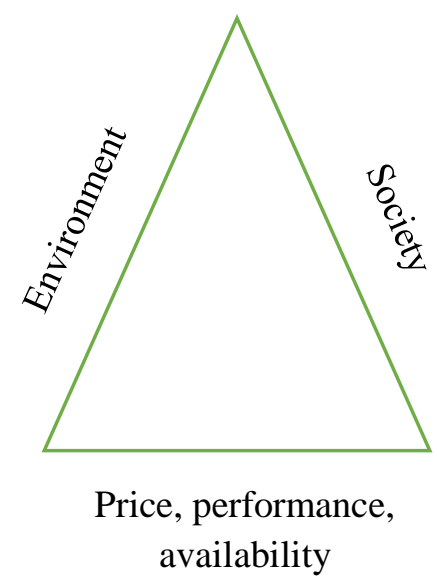

Fig. 5 Sustainable public procurement.

The above Figure pictures the three main areas or pillars of sustainable development that can be addressed by a sustainable public purchasing, which balances economic, social and environmental goals. ${ }^{28}$ Money spent on public contracts should, in fact, contribute to the achievement of all the

\footnotetext{
${ }^{24}$ In this respect, see, C McCrudden, Buying Social Justice: Equality Government Procurement and Legal Change (Oxford University Press, 2007), 331, 363.

${ }^{25}$ A Semple, A Practical Guide to Public Procurement (Oxford University Press, 2015), 171.

${ }^{26}$ Sustainable Public Procurement in EU Member States: Overview of Government Initiatives and Selected Cases, Final Report to the EU High-Level Group on CSR, R Steurer, G Berger, A Konrad, A Martinuzzi, Research Institute for Managing Sustainability, Vienna University of Economics and Business Administration, 2007, available at http://sustainability.eu/pdf/csr/policies/Sustainable\%20Public\%20Procurement\%20in\%20EU\%20Member\%20States_Fi nal\%20Report.pdf.

${ }^{27}$ Definition elaborated by the Multistakeholder Advisory Committee of the 10YFP Program, Procuring the Future, Report of the UK Sustainable Procurement Task Force, June 2006.

${ }^{28}$ Numerous researches, guidance and similar materials on sustainable public procurement are referred to in this Chapter. Among others, see the Buying Green! - A Handbook on Green Public Procurement, 2016, available at http://ec.europa.eu/environment/gpp/pdf/Buying-Green-Handbook-3rd-Edition.pdf. SEAD Initiative, Us Department of Energy, Energy-Efficient Public Procurement: Best Practice in Program Delivery, 2013. The Irish Environmental Protection Agency, Green Procurement Guidance for the Public Sector, 2014, available at http://greenbusiness.ie/wp-content/uploads/2014/09/GreenProcurementGuidanceforPublicSector-web.pdf. 
pictured objectives. For instance, public buildings should be constructed in a cost effective, socially inclusive and environmentally friendly way. Sustainable public procurement entails that contracting authorities are willing to reduce the environmental and social impacts of the goods and/or services that they buy during their entire life cycle, while at the same time pursuing more traditional economic efficiency objectives. ${ }^{29}$ Resources should be managed in a way that guarantees that future society is not left without their benefits. Environmental impacts, such as greenhouse emissions or water and soil pollution, should be reduced as much as possible. Costs should be evaluated over the entire life-cycle of an asset in order to escape from unforeseen future expenses. Activities that negatively affect social value, such as tax evasion or unfair commercial practises, should be avoided.

Indeed, public purchasing decisions that implement social and environmental considerations are complex because they often entail trade-offs between impacts which are neither visible nor, in some cases, measurable. ${ }^{30}$ In addition, from an environmental and/or social perspective, the decision to use a certain new material involves the collection of reliable data on the efficiency of the newer with respect to the existing one as well as any ancillary impact element. Nonetheless, the public sector is overall increasingly committing itself to the identification and prioritization of social and environmental considerations in public purchasing. ${ }^{31}$ At EU level, public procurement has become one of the most important actions through which sustainable development goals are implemented and secured. For instance, the Commission, in its Green Paper on modernisation of EU public procurement policy, identified the strategic use of public procurement as one of its major legislative reform goals. ${ }^{32}$

Given the recognition of public procurement as a strategic policy instrument for the implementation of sustainable development considerations, it is now important that EU public procurement rules concretely enable procurement in line with Europe's 2020 objectives. Hence, contracting authorities must be actually able to carry out public procurement strategies consistent with sustainable development policy objectives. In this respect, and as it will be discussed below, the 2014 Directives indeed provide avenues for the incorporation of sustainable development considerations at each stage of public contracts awarding procedures. However, further steps still need to be taken.

\section{The scope for sustainable development in EU public contracts and concession law.}

Social and environmental aspects, or better, sustainability objectives understood as impacts on longer-term human and environmental welfare, cannot be considered as yet fully implemented into

\footnotetext{
Procura+, European Sustainable Procurement network, The Procura+Manual: A Guide to Implementing Sustainable Procurement, 2016, available at

http://www.procuraplus.org/fileadmin/user_upload/Manual/Procuraplus_Manual_Third_Edition.pdf;

${ }^{29}$ Such as a lower expenditure.

${ }^{30}$ See below paragraph 5.4 and A Semple, A Practical Guide to Public Procurement, op. cit., 184.

${ }^{31}$ In this respect, certain sectors have their own legal framework, such as revised Environmental Impact Assessment Directive 2014/52/EU for the construction (and major infrastructures) sector. The mentioned Directive covers the evaluation of impacts of certain private and public projects on the environment.

${ }^{32}$ Green Paper on the Modernisation of EU Public Procurement Policy: European Commission, 'Towards a more efficient European Procurement Market', Brussels, 27.1.2011, COM (2011) 15 final.
} 
EU public contracts and concessions law. ${ }^{33}$ Indeed, the 2014 Directives represent an important opportunity in this respect as they, for instance, allow the incorporation, into public contracts' awarding procedures, of sustainability considerations, such as tax payments or access of SMEs, sheltered workshops and social enterprises. ${ }^{34}$ However, the large majority of sustainable-related provisions included in the 2014 Directives are optional for the public sector. Thus, their application greatly depends on the political will and relevant regulatory or policy incentives. Bearing this in mind, the following paragraphs will investigate the actual spaces for social and environmental considerations recognised by the EU public contracts and concessions law. Thus, it will be discussed which is the scope for sustainable development objectives within the EU public procurement regime. As it will be seen, the relevant legal framework allows spaces for sustainable development concerns through both mandatory measures ${ }^{35}$ and voluntary initiatives. ${ }^{36}$

\subsection{The International level.}

At an International level, the WTO Plurilateral Agreement on Government Procurement (hereinafter GPA) allows scope for social and environmental sustainability within public procurement ${ }^{37}$ and since the EU is part of this agreement, it is bound by its provisions. The GPA generally refers to the principles of non-discrimination and transparency, sets out rules on technical specifications, tenderers' selection and tenders' evaluation. Then, it specifically and expressly foresees that environmental considerations may be incorporated into technical specifications and award criteria. Article X, para 6, provides that technical specifications may 'promote the conservation of natural resources or protect the environment'. Moreover, environmental features are indicated among the evaluation criteria of Article X, para 9. Social considerations are, instead, not mentioned. Nonetheless, they are considered admissible as long as they respect the general principles' requirements. ${ }^{38}$

\subsection{The European level.}

At European level, a number of primary law provisions support the inclusion of sustainable development concerns within all EU activities, hence, also within public procurement policies.

First of all, the concept of sustainable development is embodied in Article 11 of the TFEU. The latter, in fact, calls for environmental considerations to be included into the structure and implementation of all EU policies and activities, specifically with the aim of promoting sustainable development. Article 11 reads as follows.

\footnotetext{
${ }^{33}$ See, among others, the study on 'The uptake of green public procurement in the EU27, submitted to the European Commission, DG Environment and prepared by the Centre for European Policy Studies, 2012, available at http://ec.europa.eu/environment/gpp/pdf/CEPS-CoE-GPP\%20MAIN\%20REPORT.pdf.

${ }^{34}$ Social considerations may cover several issues. These may be grouped in the following way. Supply chain impacts, such as extraction of raw materials, working conditions, manufacture or processing. End-user impacts, such as characteristics of a product, service or work which determine its social utility, accessibility to all users and the added value related with employment, training or apprenticeship.

${ }^{35}$ Those related to energy-efficiency, vehicle emissions and treatment of abnormally low tenders.

${ }^{36}$ For instance, the use of environmental management systems, life-cycle costing and environmental or social labels.

${ }^{37}$ European Commission, Internal Market and Services, EU public procurement legislation: delivering results, available at http://ec.europa.eu/internal_market/publicprocurement/docs/modernising_rules/executive-summary_en.pdf.

An updated version of the GPA was agreed upon in 2012, see further details at

https://www.wto.org/english/tratop_e/gproc_e/gp_gpa_e.htm.

${ }^{38}$ D C Dragos, B Neamtu, 'Sustainable Public Procurement in the EU: Experiences and Prospects', op. cit., 315. 
'Environmental protection requirements must be integrated into the definition and implementation of the Union's policies and activities, in particular with a view to promoting sustainable development.'

In addition, Article 9 of the TFEU provides that the following aspects have to be implemented into EU policies

'requirements linked to the promotion of a high level of employment, the guarantee of adequate social protection, the fight against social exclusion, and a high level of education, training and protection of human health.'

Along the same lines, Article 10 of the TFEU states that EU policies

'shall aim to combat discrimination based on sex, racial or ethnic origin, religion or belief, disability, age or sexual orientation.'

Finally, it can be mentioned the Charter of Fundamental Rights of the EU, ${ }^{39}$ which is relevant for EU institutions, bodies, offices and agencies, but also for Member States whenever they implement EU law. In the latter case, according to Article 51 of the Charter, they have to respect and promote its application. Thus, for instance, Article 37 of the Charter bound Member States in the implementation of the 2014 public procurement Directives. Article 37 expressively envisages room for sustainability concerns in every EU policy by stating that

\begin{abstract}
'A high level of environmental protection and the improvement of the quality of the environment must be integrated into the policies of the Union and ensured in accordance with the principle of sustainable development.'
\end{abstract}

\title{
3.3. Secondary legislation.
}

At European level, sustainable development objectives are pursued also by secondary legislation adopted in the areas of environmental protection - more specifically, energy and climate change social inclusion and equality. Secondary EU public contracts and concession law deals with a wide range of social and environmental concerns. In some cases, secondary law reaffirms obligations already imposed on suppliers, such as rules on waste disposal or on maximum working hours contractually provided. ${ }^{40}$ For instance, it is the case of the compliance with the Waste Framework Directive, 2008/98/EC, the Packaging and Packaging Waste Directives 94/62/EC and 2004/12/EC and the Working Time Directive, 2003/88/EC. Other times, secondary legislation introduces newly set requirements to be met within the procurement process, such as the obligation to procure only equipment that satisfies certain minimum energy performance levels. In this respect, for instance,

\footnotetext{
${ }^{39}$ The Charter of Fundamental Rights of the European Union, (2012/C 326/02). On December 2009, when the Treaty of Lisbon came into force, the Charter became legally binding on EU institutions and national governments as any other EU Treaty.

${ }^{40}$ See, D C Dragos, B Neamtu, 'Sustainable Public Procurement in the EU: Experiences and Prospects', op. cit., 308. 
the EU Directive on energy efficiency ${ }^{41}$ provides for minimum requirements for ordinarily procured goods and services, which are foremost identified through reference to pre-existing standards, such as the energy efficiency requirements listed in Annex $\mathrm{C}$ of the Agreement attached to the Council Decision 2006/1005/EC. ${ }^{42}$ Compliance with such energy efficiency standards is, however, imposed only if it is cost-effective, economic feasible, sustainable, technically suitable and sufficiently competitive. $^{43}$

The following Tables provide for a non-exhaustive overview of EU secondary legislation allowing room for social and environmental sustainability in public procurement. For most legislative pieces, there are national implementation measures into place. ${ }^{44}$ Unfortunately, the 2014 procurement Directives do not specifically mention the EU legislation indicated in the below Tables. Article 18, para 2, Directive 2014/24/EU, ${ }^{45}$ only mentions in general terms, 'social and labour law established by Union law, national law, collective agreements or by the international environmental, social and labour law provisions listed in Annex X' ${ }^{46}$

\section{EU environmental legislation that allows scope for sustainable development concerns in public procurement}

\section{Piece of Legislation}

Waste Waste Framework Directive, 2008/98/EC

Packaging and Packaging Waste, Directives 94/\&"/EC and 2004/12/EC

Energy

Energy Efficiency Directive, 2012/27/EU

Renewable Energy Directive, 2009/28/EU

Energy Performance of Buildings Directive, 2010/31/EU

\section{Energy Labelling Directive,} 2010/30/EU

Water

Water Framework Directive,

\section{How sustainable development goals are} secured?

Costs and responsibilities in waste management are regulated.

Packaging of waste is regulated (separation and re-use).

Energy efficiency standards are set in order to be included by central government's procurement of supplies, services and works.

Criteria for sustainable biofuels are set.

Origin certificates must be recognised as evidence of renewable production.

The public sector has to own and operate buildings that meet minimum energyefficiency requirements.

Common consumer appliances have to meet efficiency classes and labelling requirements.

Requires recovery of costs of water

\footnotetext{
${ }^{41}$ Article 6 and Annex III, Directive 2012/27/EU of the European Parliament and of the Council of 25 October 2012 on energy efficiency, amending Directives 2009/125/EC and 2010/30/EU and repealing Directives 2004/8/EC and 2006/32/EC Text with EEA relevance.

${ }^{42}$ Council Decision, 18 December 2006, on the conclusion of the Agreement between the Government of the United States of America and the European Community on the coordination of energy-efficiency labelling programmes for office equipment (2006/1005/EC).

${ }^{43}$ Article 6 and Annex III of Directive 2012/27/EU on energy efficiency.

${ }^{44}$ A Semple, A Practical Guide to Public Procurement, op. cit., 173.

${ }^{45}$ Equal provisions can be found in Article 36, para 2, Directive 2014/25/EU and Article 30, para 3, Directive 2014/23/EU.

${ }^{46}$ Indicated in Annex X, Directive 2014/24/EU, Annex XIV, Directive 2014/25/EU and Annex X, Directive 2014/23/EU.
} 
2000/60/EC

\section{IT, electronic and electrical equipment}

Energy Star Regulation n. 106/2008

Restriction of Hazardous Substances

Directive, 2002/95/EC

Waste Electronic and Electrical

Equipment Directive 2012/19/EU

Wood and paper Timber Regulation n. 995/2010

Vehicles Clean Vehicles Directive, 2009/33/EC

European Emission Standards

Regulation n. 715/2007 (Euro 5 and 6)

Certification Ecolabel Regulation n. 66/2010

Eco-management and Audit Scheme Regulation, n. 1221/2009

Organic Regulation n. 834/2007 and n. $889 / 2008$ services.

Government procurement of office IT equipment has to set minimum energyefficiency standards.

Specific hazardous substances cannot be contained in purchased electrical and electronic equipment.

Equipment has to be labelled by producers for recycling purposes and taken back at the end of its life.

Harvest sources must be identifiable for wood and paper products.

Lifetime energy consumption, emissions and noise of road transport vehicles must be considered.

Maximum emissions standards are set for vehicles on the market after a set date.

The identification of environmental friendly products is supported.

Means for contractors to prove compliance with environmental measures are provided.

Certain standards for organic certification and labelling are provided.

Table 7 EU Environmental legislation.

\section{EU social legislation that allows room for sustainable development concerns in public procurement}

Piece of Legislation

Transfer of Undertakings,

Employment

Equality
Protection of Employees

Directive, 2001/23/EC

Working Time Directive, 2003/88/EC

Posted Workers Directive, 96/71/EC

Equal treatment of men and women Directive, 2006/54/EC

Non-discrimination upon racial or ethnic origin Directive, 2000/43/EC

\section{How sustainable development goals are secured?}

Terms and conditions of employees upon transfer of an undertaking are maintained.

Night and shift works are regulated. Daily and weekly rests, breaks and annual leaves are set.

Minimum conditions of employment are guaranteed to workers from other Member States.

Direct or indirect discrimination because of sex is not allowed in employment, training and pay.

Direct or indirect discrimination because of race or ethnicity is not allowed in employment, training and pay. 
Disability

Equal treatment in employment and occupation Framework Directive, 2000/78/EC

Council Decision on Rights of Persons with Disabilities, 2010/48/EC

\section{Services of general interest $^{47}$}

\section{Health and safety}

Protocol n. 26 to the TFEU on Services of General Interest

Universal and Public Service Obligations (several directives)

Health and Safety of Workers at Work Directive, 89/391/EEC

Protection from Exposure to Asbestos Directive, 2009/148/EC
Employers provide disabled persons with accommodation for access or advancement in employment.

Communication, technical specifications, award criteria and contract performance conditions have to respect rights of disabled persons.

National, regional and local authorities can discretionally provide, commission and organize services of general interest.

Specific services in the postal, energy, transport and telecommunication fields can be paid according to different rules.

Specific rules on safety are set.

Working procedures must limit exposure to asbestos and other related risks.

Table 8 EU Social legislation.

\subsection{Soft law.}

The EU Commission has clarified how social and environmental considerations may be integrated within the scope of public procurement through the enactment of a number of soft law measures, which aim at providing guidance to the public sector in the path of sustainable development.

In 2004, it adopted the Buying Green Handbook on green public procurement, which was recently revised in 2011 and in $2016 .{ }^{48}$ This document represents an important tool supporting procurers in the choice of goods and services that have a lower environmental impact. It is also meant to help economic operators to include environmental considerations into their tenders. The Handbook goes through each phase of the procurement process and explains how environmental concerns can be integrated. It also provides for practical experiences from contracting authorities around the EU. Additionally, a specific section of the guide is dedicated to green procurement in certain specific fields, such as buildings, food, catering services, road transport vehicles and energyusing products. ${ }^{49}$ Another insightful soft law measure is the 2008 Communication on 'Public Procurement for a Better Environment. ${ }^{50}$ This document identified Member States' objectives for the achievement of various green public procurement targets before 2010. Accordingly, some Member States committed themselves to $100 \%$ green procurement for certain products, while others

\footnotetext{
${ }^{47}$ Services of general economic interest are economic activities that generate outputs in the general public good, which would not be delivered by the market without public intervention. See the Commission Staff Working Document, Guide to the Application of the European Union Rules on State Aid, Public Procurement and the Internal Market to Services of General Economic Interest and in Particular to Social Services of General Interest SWD, 2013, 53 final/2.

${ }^{48}$ The full text of 'Buying Green! - A Handbook on green public procurement', as revised in 2016, is available at http://ec.europa.eu/environment/gpp/pdf/Buying-Green-Handbook-3rd-Edition.pdf.

${ }^{49}$ See Chapter 7 of the 'Buying Green! - A Handbook on green public procurement', ibid.

${ }^{50}$ Communication from the Commission to the European Parliament, the Council, the European Economic and Social Committee and the Committee of the Regions, Public Procurement for a Better Environment, Brussels, 16.7.2008 COM (2008) 400 final.
} 
set $20 \%$ target. ${ }^{51}$ The Commission's suggestion was that by $2010,50 \%$ of all tender procedures had to be 'green,' meaning compliant with the 'endorsed common "core" GPP criteria'. 52

The Commission's support for socially responsible procurement has been less intense than the one given to green public procurement, but still important. In this respect, the Buying Social Guide can, for instance, be mentioned. This document aims at supporting the public sector in the procurement of goods and services in a socially responsible way. ${ }^{53}$ The guide holds that public procurement has the potential of being used in order to foster greater social inclusion, which is a key element of a sustainable development. The guide contains a range of examples on how to integrate social issues in the procurement process. It takes into consideration aspects of equal employment opportunities, improvement of working conditions and inclusion of vulnerable persons. It also offers examples of compliance with the provisions of the most relevant International Labour Organization (hereinafter ILO) conventions, however, highlighting especially what is not allowed under EU law rather than what can be done. This is probably because of the higher legal uncertainty surrounding the inclusion of social aspects into competitive tender procedures. Social considerations are, in fact, perceived as contradicting the economic objectives underlying the principle of free competition upon which procurement rules are mainly structured. They may affect market competition and secure local protection and, thus, need to be subject to strict proportionality requirements to avoid risk of abuses of discretion and/or protectionism. Therefore, their inclusion in public contracts is seen as complex and time-consuming accompanied by risks of delays for judicial procedures. ${ }^{54}$ Moreover, the discretionary nature of the provisions of the 2014 public procurement Directives allowing the integration of social considerations into public contracts, increases such legal uncertainty and discourages their use by contracting authorities. As it will be seen, ${ }^{55}$ the 2014 public procurement Directives made little, yet important, steps further towards the strengthening of social protection concerns into public purchasing. For instance, one can mention the express possibility to include trading conditions into award criteria. However, the Directives highly rely on Member States and contracting authorities' discretion. In the field of compliance with applicable social and labour provisions, the only over-riding obligation imposed on Members States is the one set out in Article 18, para 2, Directive 2014/24/EU, ${ }^{56}$ which requires national legislators to take 'appropriate measures' to guarantee that in the performance of public contracts the applicable environmental, social and labour laws are respected. This provision is formulated in a vague way, hence, its effectiveness depends on the relevant national implementing measures. Furthermore, the only obligations directly imposed on contracting authorities are those related to sub-contracting at the performance stage ${ }^{57}$ and rejection of abnormally low tenders in case of non-compliance with

\footnotetext{
${ }^{51}$ W Kahlenborn, C Moser, J Frijdal, M Essig, 'Strategic Use of Public Procurement in Europe', Final Report to the European Commission, PPRC, Aldelphi, Belmont, MARKT/2010/02/C, 2011, available at

http://ec.europa.eu/internal_market/publicprocurement/docs/modernising_rules/strategic-use-public-procurementeurope_en.pdf.

52 Point 5.1 of the Communication from the Commission to the European Parliament, the Council, the European Economic and Social Committee and the Committee of the Regions, Public Procurement for a Better Environment, Brussels, 16.7.2008 COM (2008) 400 final.

${ }^{53}$ Buying Social, A Guide to Taking Account of Social Considerations in Public Procurement, European Commission Directorate-General for Employment, Social Affairs and Equal Opportunities, 2010.

${ }^{54} \mathrm{~N}$ Bruun, K Ahlberg, 'Public procurement and labor rights: governing by scaremongering' in S Evju (ed), Regulating transnational labor in Europe: the quandaries of multilevel governance (Privatrettsfondet, 2014) 263, 279.

${ }^{55}$ See below paragraph 3.6.

${ }^{56}$ Also Article 30, para 3, Directive 2014/23/EU.

${ }^{57}$ Article 71, para 1, Directive 2014/24/EU.
} 
social and labour laws. ${ }^{58}$ This means that the actual inclusion of social considerations in procurement procedures largely depends on discretionary measures and decisions, thereby increasing legal uncertainty, which goes against simplification objectives and prevents the creation of a level playing field.

Overall, the adoption of soft law measures in the field of socially sustainable public procurement may be useful to reflect the current wider space recognized by the 2014 Directives to social considerations in the procurement process. ${ }^{59}$ However, a mandatory approach to the inclusion of social concerns in public purchasing procedures would probably be more desirable for a number of reasons. First of all, social standards' respect should be inherently part of any public contract and should not be left to a discretional choice of Member States or contracting authorities. Moreover, the normative choice of making use of public procurement to support also the achievement of objectives other than competition has already been taken with the adoption of the 2014 public procurement Directives. ${ }^{60}$ Furthermore, the mandatory inclusion of social value would not contradict other procurement goals, such as free movement of goods and free provision of services within the EU. Instead, it would support simplification and transparency contributing to the achievement of the single market objectives by creating a level playing field. Economic operators would more easily understand and respect social standards if these were integrated in public contracts as minimum mandatory requirements in every Member State and in all phases of procurement procedures. Accordingly, suppliers would not be able to obtain unfair competitive advantages through the abuse of human rights and the adoption of indecent working conditions by using lower prices than those offered by operators that comply with national and international labour legislations.

At the national level, the overall majority of Member States adopted their own policy measures implementing sustainable public procurement. ${ }^{61}$ Some of them support the procurement of greener services and/or products, while others identify only indicative objectives. Where national policy instruments set criteria to be applied within their procurement process, they usually refer to the common green public procurement criteria elaborated by the EU Commission, which cover more than 20 service and products' areas. ${ }^{62}$ The common green criteria address the most important environmental impacts of specific products and services by taking into consideration their entire life cycle. ${ }^{63}$ Normally, the criteria nationally adopted also include social considerations, such as aspects of accessibility to all end-users, exclusion of child labour, or fair wages of the persons involved in

\footnotetext{
${ }^{58}$ Article 69, para 3, Directive 2014/24/EU.

${ }^{59}$ Again, see below paragraph 3.6.

${ }^{60}$ Recital 2 and 91, Directive 24/2014/EU. In this respect, see A Wiesbrock, 'Socially responsible public procurement, European Value or national choice?' in B Sjafjell, A Wiesbrock (eds), Sustainable Public Procurement Under EU Law, (Cambridge University Press, 2016) 94.

${ }^{61}$ The National GPP Action Plans available at http://ec.europa.eu/environment/gpp/action_plan_en.htm contains a comprehensive overview of the state of art in the EU Member States.

${ }^{62}$ Since 2010, the Commission collects examples of GPP implementations to show how public authorities around the EU are successfully launching green tenders. In this respect, see the 'GPP brochure of good practice examples', which includes useful case studies aiming at inspiring public and private actors to purchase green products and services. The full text is available at http://ec.europa.eu/environment/gpp/pdf/GPP_Good_Practices_Brochure.pdf. The updated status of the EU GPP is, instead, available at http://ec.europa.eu/environment/gpp/eu_gpp_criteria_en.htm.

${ }^{63}$ See, A Semple, A Practical Guide to Public Procurement, op. cit., 176. 
procurement processes. ${ }^{64}$ Moreover, several local and regional entities implement their own specific policies, which often go beyond the general targets set by national measures. ${ }^{65}$

\subsection{The CJEU case law.}

The CJEU case law played an important role in specifying the scope for sustainable development goals within EU public contracts and concessions law. The CJEU opened, in fact, the way to the use of social and environmental considerations into public procurement.

Traditionally, according to the CJEU, the main goal of EU law, in the field of public procurement, was to promote competition within the Member States' public markets and guarantee the free movement of goods and services throughout the EU. ${ }^{66}$ However, the following decisions show that the Court is slowly starting to change its perspective by making room also for other objectives - not purely economic - among those legitimately pursuable by contracting authorities.

In 1988, the CJEU had to decide in Gebroeders Beentjes on a Dutch case where a tenderer for a works contract did not win the bid because of another more expensive tender, which was considered by the public authority more beneficial. ${ }^{67}$ One of the main reasons lying behind the choice of the preferred bid was that the bidder was able to fulfil a condition included in the tender documents concerning the employment of long-term unemployed people for the execution of the works. The CJEU stated that this condition was compatible with EU law as long as it was not directly or indirectly discriminatory with respect to other Member States' tenderers and it was expressly indicated in the contract notice. ${ }^{68}$ Given that this case arose out a reference for a preliminary ruling, the identification of the specific impact of such condition had to be decided by the national legislator. With this judgement, the CJEU, showed itself to be open to the recognition of a wider social function of public procurement.

Ten years later, the Commission questioned the award in the French Nord-Pas de Calais region of school-building contracts covering an 'additional award criterion' related to local

\footnotetext{
${ }^{64}$ For instance, in 2014, the Italian Government issued a document, The Foundations of the Italian Action Plan on the United Nations 'Guiding Principles on Business and Human Rights', English text available at http://www.mit.gov.it/mit/mop_all.php?p_id=18077. This document dedicates an entire Chapter (Chapter 6) to the integration of human rights in public procurement and refers to the Italian guide on the inclusion of social criteria into public contracts elaborated by the Ministry of the Environment. Text available at http://www.minambiente.it/sites/default/files/archivio/allegati/GPP/GUDMxALL.pdf. For further details, see below Chapter IV, paragraph 4.1.

${ }^{65}$ For instance, in the Piemonte Region in Italy, the APE project, initiated in 2003 (with the support of the Regional Agency for the Protection of Environment), committed its partners (local public entities) to integrate environmental criteria in the purchase of numerous products and service categories. Only in 2015, the national law adopted and imposed minimum environmental criteria. For further details, see below Chapter IV, paragraph 4.1. Moreover, the Procura+Campaign (http://www.procuraplus.org/), the United Nations (especially the United Nations Environment Program, UNEP) and the European Investment Bank provide a continuous support, especially to local authorities, in the implementation of sustainable procurement.

${ }^{66}$ See, for instance, para 31, C-454/06, Pressetext Nachrichtenagentur GmbH v Republik Österreich (Bund), [2008] I04401. Para 81, C-513/99, Concordia Bus Finland Oy Ab, formerly Stagecoach Finland Oy Ab v Helsingin kaupunki and HKL-Bussiliikenne, [2002] I-07213. C H Bovis, EU Public Procurement Law (Edward Elgar, 2007) 488. C H Bovis, The Liberalization of Public Procurement and its effects on the Common Market (Ashgate, 1998) 229. M Comba, 'Green and Social Considerations in Public Procurement Contracts: A Comparative Approach' in R Caranta and M Trybus (eds), The Law of Green and Social Procurements in Europe (DJØF, 2010). S Arrowsmith, The Law of Public and Utilities Procurement, Regulation in the EU and UK (Sweet \& Maxwell, 2014) 239.

${ }^{67}$ C-31/87, Gebroeders Beentjes BV v State of the Netherlands, [1988] 04635. A Colabianchi, 'Ancora in tema di direttive comunitarie sugli appalti' [1990] Giustizia Civile, 586, 588.

${ }^{68}$ Point 37, C-31/87, ibid.
} 
employment. ${ }^{69}$ This criterion was defined according to an inter-ministerial circular implementing a French national policy measure on unemployment reduction. According to this policy, when two bids were found to have an equal value, a commitment towards unemployed workers was decisive. In this case (Nord-Pas de Calais), the CJEU stated that conditions pertaining to unemployment could indeed be used as award criteria if they complied with the fundamental principles of Community law, especially with the principle of non-discrimination. ${ }^{70}$ Thus, the Court confirmed the possibility to integrate social considerations - foremost those relating to employment - in award criteria and/or contract performance clauses within procurement procedures.

The PreussenElektra case, instead, regarded State aid in the field of renewable electricity. ${ }^{71}$ The case concerned a German law, which required energy supply companies to purchase, at defined minimum charges, renewable electricity produced in their area of supply. The CJEU stated that this German law was compatible with the Treaty because it aimed at fighting climate change while promoting the integration of renewable electricity markets. ${ }^{72}$ Therefore, the Court expressed its opinion on the legal obligations stemming from the Treaty commitments on sustainable development and on the issue of whether environmental considerations could be taken into consideration when interpreting the Treaty provisions on free movement of goods. Thus, with this judgment, the Court offered an instance of the extent to which environmental actions, which may be considered discriminatory in nature, can be justified.

In 1999, the CJEU then decided on a case concerning an invitation to tender in the city of Helsinki for bus transport services (Concordia Bus Finland). ${ }^{73}$ Nitrogen oxide emissions and noise

${ }^{69}$ C-225/98, Commission of the European Communities v French Republic, [2000] I-07445. K Krüger, 'Noneconomical "soft" and "green" considerations in public contract award procedures' [2002] Europarättslig tidskrift, 57, 67. J Joël, 'A propos des clauses sociales dans les marchés publics de travaux. Un arrêt étonnant de la Cour de justice des Communautés européennes' [2001] Journal des tribunaux, 561, 564. R Williams, 'The proposed Commission Draft Communication on the Environment and the impact of the Nord Pas-de-Calais Region case' [2001] PPLR, 75, 80. J Arnould, 'A Turning Point in the Use of Additional Award Criteria?' [2001] PPLR, 13, 19. P Lefèvre, 'Les considérations sociales et environnementales dans les marchés publics européens' [2000] Journal des tribunaux/droit européen, 245, 247.

${ }^{70}$ Paras 49-54, C-225/98, ibid. Following C-45/87, Commission of the European Communities $v$ Ireland, [1988] 04929, if a criterion did not comply with the non-discrimination principle it could have not been accepted.

${ }^{71}$ C-379/98, PreussenElektra AG v Schhleswag AG, in the presence of Windpark Reußenköge III GmbH and Land Schleswig-Holstein, [2001] I-02099. T Kuhn, 'Implications of the "Preussen Elektra" Judgment of the European Court of Justice on the Community Rules on State Aid and the Free Movement of Goods. Preliminary Ruling of 13 March 2001, Case C-379/98, Preussen Elektra v. Schleswag' [2001] Legal Issues of Economic Integration, 361, 376. L Rubini, 'Brevi note a margine del caso PreussenElektra, ovvero come "prendere seriamente" le norme sugli aiuti di stato e la tutela dell'ambiente nel diritto comunitario' [2001] Diritto Comunitario e degli Scambi Internazionali, 473, 501. M Bronckers, R Van der Vlies, 'The European Court's PreussenElektra Judgment: Tensions Between E.U. Principles and National Renewable Energy Initiatives' [2001] European Competition Law Review, 458, 468. J M Belorgey, S Gervasoni, C Lambert, 'Environnement et libre circulation des marchandises' [2001] L'actualité juridique droit administrative, 944, 946. C Golfinopoulos, 'Legality of National Measures to Promote the Procurement of Energy from Renewable Sources' [2002] PPLR, 8, 11. S Poli, 'National Schemes Supporting the Use of Electricity Produced from Renewable Energy Sources and the Community Legal Framework' [2002] Journal of Environmental Law, 221, 231. C Koenig, J Kühling, 'EC Control of aid granted through State resources' [2002] European State Aid Law Quarterly, 7, 18. A Colavecchio, 'Aiuti di Stato, ostacoli al commercio tra Stati membri ed esigenze di tutela dell'ambiente nella giurisprudenza comunitaria. A proposito della sentenza della Corte di giustizia nel caso "Preussenelektra"' [2003] Il Consiglio di Stato, 631, 664.

${ }^{72}$ C-379/98, ibid., paras 73-81.

${ }^{73}$ C-513/99, Concordia Bus Finland Oy Ab, formerly Stagecoach Finland Oy Ab v Helsingin kaupunki and HKLBussiliikenne, [2002] I-07213. P Kunzlik, 'Making the Market Work for the Environment: Acceptance of (Some) "Green" Contract Award Criteria in Public Procurement' [2003] Journal of Environmental Law, 188, 201. L Bonechi, 'Offerta economicamente più vantaggiosa: la Corte ribadisce la legittimità dei criteri di valutazione di natura non economica' [2003] Diritto pubblico comparato ed europeo, 453, 455. S Izzo, 'La tutela dell'ambiente non é un valore 94 
levels where included in the criteria for the identification of the most economically advantageous tender. The CJEU remarkably upheld the legitimacy of environmental considerations as award criteria if they

(i) were linked to the subject-matter of the contract,

(ii) did not provide an unlimited freedom of choice to the public sector,

(iii) were expressively indicated in the contract notice or tender documents and

(iv) were consistent with the fundamental Treaty principles, especially with the non-discrimination principle. ${ }^{74}$

As it will be explained in more detail below in paragraph 3.6, letter $\mathrm{f}$ ), these criteria are now codified - respectively - in Directive 2014/24/EU, Article 67, paras 2, 4 and 5. Recital 1 and 90, Directive 2014/24/EU, then states that award criteria have to comply with the principles of the TFEU and the principles deriving therefrom, such as, inter alia, the principle of non-discrimination.

The EVN Wienstrom decision on the purchase by the Austrian Government of renewable electricity can be mentioned together with the Concordia judgement. ${ }^{75}$ In the EVN Wienstrom case, the CJEU, first of all, stated that it was possible to use ecological award criteria even if they did not provide an immediate economic benefit to the contracting authority. In addition, it held that a high score in the overall evaluation of bids could be attached to such criteria. Moreover, the Court clarified that it was legitimate to set an award criterion linked to the production method of the purchased product. Nonetheless, such criterion had to be linked with the subject-matter of the contract and be verifiable. ${ }^{76}$ The Court stated that the award criterion that considered the supplier's overall ability to provide renewable electricity did not have the required link with the subject-matter of the contract, because it did not refer to defined quantities indicated in the contract. The CJEU also held that the contracting authority could not effectively verify performance with such criterion. ${ }^{77}$ Additionally, the Court considered that this award criterion manifestly discriminated against other tenderers. The latter were, in fact, treated unequally because they may have not been able to meet the general award criterion that considered the overall ability to provide renewable

assoluto' [2003] Diritto pubblico comparato ed europeo, 455, 458. J Arnould, 'Environmental Criteria and the EC Procurement Directives: A Note on the Concordia Bus Finland Case' [2003] PPLR, 3, 8. M Lottini, 'Appalti comunitari: sull'ammissibilità di criteri di aggiudicazione non prettamente economici' [2002] Il Foro amministrativo, 1950, 1957. A Ménéménis, 'Le recours à des critères environnementaux dans l'attribution des marchés' [2002] Droit administrative, 174.

${ }^{74}$ Para 64, C-513/99, ibid.

${ }^{75}$ C-448/01, EVN AG and Wienstrom GmbH v Republik Österreich, [2003] I-14527. G Garzia, 'Bandi di gara per appalti pubblici e ammissibilità delle clausole c.d. "ecologiche"' [2003] Il Foro amministrativo, 3515, 3525. T Gliozzo, 'L'admissibilité d'un critère environnemental au regard de la réglementation communautaire des marhcés' [2004] L'actualité juridique; droit administratif, 335, 337. M Dischendorfer, 'The Rules on Award Criteria Under the EC Procurement Directives and the Effect of Using Unlawful Criteria: The EVN Case' [2004] PPLR, 74, 84. D U Galetta, 'Vizi procedurali e vizi sostanziali al vaglio della Corte di giustizia (che non si pronuncia sulla questione)' [2004] Rivista italiana di diritto pubblico comunitario, 317, 324. V De Falco, 'L'utilizzo di fonti di energia rinnovabili come criterio di valutazione dell'offerta economicamente più vantaggiosa: la legge austriaca a confronto con l'ordinamento comunitario' [2004] Diritto pubblico comparato ed europeo, 889, 893. F Berrod, 'Critère écologique. Du maniement prudent du critère écologique dans la sélection des offres' [2004] Europe Février Comm, 13, 14.

${ }^{76}$ Para 51, C-448/01, ibid.

${ }^{77}$ Paras 67-71, C-448/01, ibid.

95 
electricity, but they could have met the one specifically referring to defined quantities of renewable electricity provision.

Following both the Concordia and EVN Wienstrom judgements, the CJEU recognised the possibility for contracting authorities to use environmental award criteria related to the specific purchased goods, services or works without referring to the general corporate policy or ability of the tenderer.

The CJEU followed such an approach in the Dutch Coffee case with regard to award criteria concerning social aspects of the supply chain. ${ }^{78}$ In this case, the Court held that award criteria do not have to refer to an intrinsic feature of a product, but may concern also aspects of its production process that do not materially modify the final good. Thus, the CJEU stated that a contracting authority may apply award criteria related to organic agriculture and fair trade in the supply of tea and coffee. The reason is that such aspects can be regarded as contract performance elements and, as such, are linked to its subject-matter. ${ }^{79}$ However, the Court ruled that the contracting authority had breached its obligations under the 2004 public procurement Directives because it awarded marks to bidders who had specific organic and fair trade labels, without indicating the precise criteria lying behind such labels. ${ }^{80}$

In the Dynamiki case, the European Environment Agency carried out a comparative evaluation of tenders in order to verify whether tenderers had put into place their environmental policies. ${ }^{81}$ This assessment showed that only one tenderer had actually implemented its policy. The others had merely stated their intention to do so. ${ }^{82}$ The court of first instance held that the European Environment Agency was allowed to take into consideration such aspects and accordingly award different marks. This case can be considered as useful guidance, even though it was decided having regard to the Financial Regulation, which regulates the award of contracts by the European Environment Agency and other EU bodies. The 2014 public procurement Directives are, in fact, alike in this matter and do not fully address the issue of environmental criteria evaluation, which entails the identification of the extent to which contracting authorities can exercise their discretion in such assessment.

In 2014, the CJEU decided two cases relating to green certificate schemes used in Sweden and Flanders. ${ }^{83}$ It has to be mentioned that the second case related to an activity explicitly sanctioned by a Directive: the use of national support schemes for the development of renewable

\footnotetext{
${ }^{78}$ C-368/10, European Commission v Kingdom of the Netherlands, published in the electronic Reports of Cases (Court Reports - general). E Adobati, 'La Corte di giustizia si pronuncia su un appalto pubblico di fornitura subordinato al rispetto di condizioni di carattere ecologico' [2012] Diritto comunitario e degli scambi internazionali, 278, 280. T Kotsonis, 'Commission v Netherlands (C-368/10): Environmental and fair-trade considerations in the context of a contract award procedure' [2012] PPLR, 234, 244. S Robin-Olivier, 'Verdissement des marchés publics: des exigences environnementales, mais pas un écolabel particulier' [2013] Revue trimestrielle de droit européen, 410.

${ }^{79}$ Paras 89-92, C-368/10, ibid.

${ }^{80}$ Paras 93-97, C-368/10, ibid.

${ }^{81}$ T-331/06, Evropaïki Dynamiki - Proigmena Systimata Tilepikoinonion Pliroforikis kai Tilematikis AE v European Environment Agency (AEE), Reports of Cases, [2010] II-00136, Appeal Case before the Court of Justice C-462/10 P.

${ }^{82}$ Para 76, T-331/06, ibid.

${ }^{83} \mathrm{C}-573 / 12$, Alands vindkraft $A B$ v Energimyndigheten, published in the electronic Reports of Cases (Court Reports general). D Berlin, 'Une harmonisation partielle empêche-t-elle l'application du traité? Non et oui' [2014] La Semaine Juridique - édition générale, 1399. M Lopez Escudero, 'Régimes nationaux d'aide à l'énergie verte face à libre circulation des marchandises dans l'Union européenne' [2014] Revue des affaires européennes, 593, 602. Joined cases C-204/12 to C-208/12, Essent Belgium NV v Vlaamse Reguleringsinstantie voor de Elektriciteits- en Gasmarkt, published in the electronic Reports of Cases (Court Reports - general). J Kröger, 'Nationally Exclusive Support Schemes for RES Electricity Production and the Free Movement of Goods' [2013] Journal for European Environmental \& Planning Law, 378, 393.
} 
energy. ${ }^{84}$ These kind of schemes help the attainment of national renewable energy objectives, which are mandatory in order to achieve the overall EU goal of $20 \%$ renewable electricity by 2020 .

According to the green certificate schemes used in Sweden and Flanders, suppliers had to provide to regulators every year certificates showing their production of renewable electricity. Such certificates were accepted only if they showed production in the area of supply. The objective was to promote the development of the renewable energy market in the territory of supply. In both cases, the CJEU stated that such schemes hindered the free movement of goods and were by nature discriminatory. However, they could have been justified in the light of their specific environmental aim. The Court stated that the proportionality of such measures could have been assessed by considering the schemes' impact in the achievement of the goal of promotion of renewable energy production. However, the CJEU did not mention the issue of whether other means, not constraining the principle of free movement to such extent, could have been equally effective. Given that both cases arose out references for preliminary rulings, the Court left the identification of the final result of the proportionality assessment to the national court.

As it will be seen, the 2014 public procurement Directives largely confirmed the CJEU case law. This will be now discussed.

\subsection{The Scope for sustainable development in the 2014 public procurement Directives.}

The way in which contracting authorities identify their requirements, set their preferences and monitor their compliance can allow the integration of sustainable development considerations into public procurement. ${ }^{85}$ Public purchasing can, in fact, be organized in a way that incorporates and supports the achievement of sustainable development objectives at every stage of its process: when defining the requirements that the contract must have, when selecting suppliers or service providers, when evaluating tenders and identifying contract clauses. ${ }^{86}$

The following paragraphs will provide an overview of the new public procurement rules that allow scope for social and environmental sustainability in public purchasing. The analysis will concentrate only on those rules that actually have the ability to incorporate sustainable development objectives within public contracts and concessions. In other words, only those provisions capable of securing socio-environmental considerations into public procurement will be highlighted. Therefore, it will be outlined how sustainable development considerations can be integrated at each stage of the procurement process under the new public procurement regime.

In this regard, it should be noted that when contracting authorities set or define technical and/or functional specifications, selection and award criteria, label requirements and/or contract performance conditions in order to purchase works, supplies or services that take into account

\footnotetext{
${ }^{84}$ Directive 2009/28/EC of the European Parliament and of the Council of 23 April 2009 on the promotion of the use of energy from renewable sources and amending and subsequently repealing Directives 2001/77/EC and 2003/30/EC.

${ }^{85}$ On sustainable public procurement in the EU see, among others, S Arrowsmith, P Kunzlik, Social and Environmental Policies in EC Procurement Law: New Directives and New Directions (Cambridge University Press, 2009). R Caranta, M Trybus, The Law of Green and Social Procurement, op. cit.. R Caranta, 'Sustainable Procurement' in M Trybus, R Caranta, G Edelstam (eds), European Union Law of Public Contracts: Public Procurement and Beyond (Buylant, 2014). W Kahlenborn, C Moser, J Frijdal, M Essig, 'Strategic Use of Public Procurement in Europe', Final Report to the European Commission, op. cit.

${ }^{86}$ In this respect see, for instance, C McCrudden, Buying Social Justice: Equality Government Procurement and Legal Change, op. cit.. A Semple, 'Reform of EU Procurement Directives and WTO GPA: Forward Steps for Sustainability' [2012] SSRN, available at http://ssrn.com/abstract=2089357 or http://dx.doi.org/10.2139/ssrn.2089357.
} 
specific environmental and/or social issues, they always have to make sure that these elements are linked with the subject-matter of the contract. ${ }^{87}$

The requirement of the link with the subject-matter of the contract was elaborated by the CJEU in the Concordia case ${ }^{88}$ and then included in the 2004 Directives only with regard to award criteria. Today, such a condition refers also to technical specifications, variants, labels and contract performance clauses. The 2014 Directives, however, do not indicate whether this requirement should be interpreted in a restrictive way or not. Only one specific restriction is expressly foreseen. Social or environmental considerations related to the overall business practises of tenderers cannot be considered as linked to the subject-matter of the contract.

In this respect, it can be noted that corporate social responsibility concerns - e.g. tax compliance or socio-environmental friendly production methods - are becoming increasingly important for both private companies and citizens' consumption decisions. ${ }^{89}$ The public sector is, instead, restrained in addressing such issues. ${ }^{90}$ An exception concerns staff qualification, experience and organization, which may be considered at the award stage provided that they are linked with the subject matter of the contract. In addition, the 2014 Directives allow the use of environmental and supply-chain management methods 'that the economic operator will be able to apply when performing the contract,' as means of proof of selection criteria. ${ }^{91}$

With regard to the interpretation of the condition of the link with the subject-matter of the contract, a restrictive approach may be found in the Concordia judgement where the CJEU stated that:
'Since a tender necessarily relates to the subject-matter of the contract, it follows that the award criteria which may be applied in accordance with [the provisions on award criteria set out in the directives] must themselves also be linked to the subject-matter of the contract. ${ }^{, 92}$

Apart from this syllogism used by the Court, it is true that tenders indeed relate to the subject-matter of the contract. However, they may also refer to other aspects, such as the characteristics of the tenderer's company, staff expertise and organization, which, as already mentioned, can now be assessed at the award stage if relevant to the subject-matter of the contract. A restrictive approach towards this requirement would not be desirable especially in view of allowing contracting authorities to implement social and environmental sustainable considerations. If a restrictive

\footnotetext{
${ }^{87}$ The requirement of the link with the subject-matter of the contract can be found in Directive 2014/24/EU, in Recitals 75, 83, 92, 97, 104 and Articles 42, 43, 58, 67 and 70. In Directive 2014/23/EU, in Recitals 63, 67, 73 and Articles 36, 38, 41. In Directive 2014/25/EU, in Recitals 85, 97, 102, 109 and Articles 60, 61, 82, 87. M Martens, S De Margerie, 'The Link to the Subject-Matter of the Contract in Green and Social Procurement' [2013] EPPPL, 8, 18. S Arrowsmith, The Law of Public and Utilities Procurement, op. cit., 739. A Semple, 'The link to the subject matter: a glass ceiling for sustainable public contracts?' in B Sjåfjell, A Wiesbrock (eds), Sustainable Public Procurement Under EU Law, New Perspectives on the State as Stakeholder (Cambridge University Press, 2015), 50, 74.

${ }^{88}$ C-513/99, op. cit..

${ }^{89}$ See the Dutch Coffee case, C-368/10, op. cit..

${ }^{90}$ C-448/01, op. cit..

${ }^{91}$ Annex XII, Part II, letters d) and g), Directive 2014/24/EU. See also Article 80, para 1, Directive 2014/25/EU and Article 38, para 7, Directive 2014/23/EU. P Trepte, Regulating Procurement, Understanding the Ends and Means of Public Procurement Regulation (Oxford University Press, 2007). S Treumer, 'The Distinction between Selection and Award Criteria in EC Public Procurement Law: A Rule without Exception' [2009] PPLR, 103. A Sanchez Graells, 'Exclusion, Qualitative Selection and Short-listing in the New Public Sector Procurement Directive 2014/24' in F Lichère, R Caranta, S Treumer (eds), Modernising Public Procurement: the New Directive (DJØF, 2014), 92, 128. S Arrowsmith, 'Special Issue - The New EU Procurement Directive: Part I, Editors Note' [2014] PPLR, 81.

${ }^{92}$ Para 59, C-513/99, op. cit.. 
interpretation of the link with the subject-matter was endorsed, the attainment of both environmental and social goals would be hindered along with the ability of the market to provide them. For instance, in a supply contract, a criterion that sets the allowed quantity of greenhouse gas emissions during goods transportation according to the distance between the production area and the delivery point, should be considered as linked with the subject-matter of the contract. Otherwise, criteria aiming at addressing climate change would not be effective.

\subsubsection{Contract design and technical specifications.}

Contract designing is an important phase for the inclusion of social and environmental concerns into the overall structure of public contracts. During this preliminary phase, public authorities set the targets and goals that the contract that they are planning to award will aim to achieve. These may be defined in terms of socio-environmental sustainability, being later endorsed into technical specifications drafted accordingly. The 2014 Directives oriented technical specifications towards an overall life-cycle approach allowing greater scope for the integration of environmental and social considerations.

Technical specifications indicate the characteristics of goods, services or works to be purchased and they can be drafted in different ways, being influenced by the subject-matter of the contract, national and local practices. They exist in all procedures, with the exception of the competitive dialogue and design contests where tenderers themselves have to propose such characteristics. Generally, in procurement procedures, when technical specifications are not met, tenders have to be rejected. ${ }^{93}$ Economic operators are, thus, highly motivated to comply with them in order to obtain the award of the contract. Therefore, technical specifications can play an important role in allowing scope for sustainability objectives into public contracts. Technical specifications are true requirements, while award criteria are contracting authorities' preferences subject to weighting. Thereby, technical specifications represent the preferred phase where sustainability considerations are usually included. ${ }^{94}$

Technical specifications may refer to the end-work, service or good, but also to its production process or to a specific process of another stage of its life cycle, even if such aspects do not form part of the material substance of the work, service or good. ${ }^{95}$ Thus, in principle, renewable electricity, biodegradable packages, organic food or recyclable construction materials can be required. Annex VII, Directive 2014/24/EU, provides for a non-exhaustive list of characteristics that may be referred to when drafting technical specifications. Technical specifications merely have to guarantee equal access to economic operators, do not hinder competition, be linked with the subject-matter of the contract and be proportionate to its objectives and value. ${ }^{96}$ Within these limits

\footnotetext{
${ }^{93}$ Article 66, para 1, letter a), Directive 2014/24/EU. Article 76, para 5, Directive 2014/25/EU. Article 36, para 3, Directive 2014/23/EU. R Bickerstaff, 'Applying the EC rules on standards and specifications in public and utilities procurement' [1994] PPLR, 153, 162. D C Dragos, B Neamtu, 'Sustainable Public Procurement in the EU: Experiences and Prospects', op. cit., 317. Buying Green! - A Handbook on Green Public Procurement, 2016, op. cit., 32. The CJEU stated the obligation of rejecting tenders that do not comply with technical specifications in the following cases. C243/89, para 37, Commission of the European Communities v Kingdom of Denmark, [1993] I-03353. C-561/12, paras 37-39, Nordecon AS and Ramboll Eesti AS v Rahandusministeerium, published in the electronic Reports of Cases (Court Reports - general).

${ }_{94}$ D C Dragos, B Neamtu, 'Sustainable Public Procurement in the EU: Experiences and Prospects', op. cit., 316.

95 Article 42, para 1, Directive 2014/24/EU. Article 60, Directive 2014/25/EU. Article 36, para 1, Directive 2014/23/EU.

${ }_{96}$ Article 42, paras 1 and 2, Directive 2014/24/EU. Article 60, paras 1 and 2, Directive 2014/25/EU. 99
} 
contracting authorities can draft them embedding social and/or environmental sustainability concerns. Specifically, technical specifications can be formulated with reference to standards, technical assessments or technical reference systems, in terms of performance of functional levels. ${ }^{97}$

Additionally, technical specifications allow scope for the integration of sustainable development considerations especially because they can set out performance or outcome-based specifications, which are capable of promoting competition, innovative and sustainable solutions. Performance-based specifications focus on the outcome and usually come together with minimum performance targets. In addition, variants, which are alternative solutions proposed by economic operators in order to meet contracting authorities' minimum needs, may also push forward innovation and the delivery of sustainable solutions. ${ }^{98}$ For instance, contracting authorities may use variants to compare traditional diesel or petrol vehicles with alternative-fuelled, electric or hybrid ones. Performance-based specifications and variants may be helpful especially when the public sector does not know which are the available solutions on the market or when different technologies need to be compared and their impact on cost and/or quality has to be assessed. The use of performance-based specifications and variants requires that the public sector knows how to apply effective evaluation methodologies and compare tenders. In other words, performance-based specifications indeed represent an effective way to promote innovative and sustainable solutions. However, they entail assessments and contract management systems, which can be challenging. Anyway, if technical specifications do not indicate optimal levels of performance, these may be achieved by means of variants and/or performance evaluations under contract award criteria and/or performance clauses.

With the exception of accessibility for disabled users, it seems that technical specifications are better able to incorporate environmental considerations than social concerns. With regard to the latter, Recital 76 of Directive 2014/24/EU, only provides that 'for all procurement intended for use by persons, [...] it is necessary for contracting authorities to lay down technical specifications so as to take into account accessibility criteria for people with disabilities or design for all users [...].' However, Recital 76 is not mandatory. Along the same lines, Recital 99, Directive 2014/24/EU, provides that 'in technical specifications contracting authorities can provide [...] social requirements which directly characterise the product or service in question, such as accessibility for persons with disabilities or design for all users.' Thus, the attention is expressly put only on accessibility for disabled users. With respect to other social considerations, such as social and labour conditions within the supply-chain, it may be argued that technical specifications cannot refer to them. However, this is not anymore the case. Social supply-chain considerations, such as fair trade, may, in fact, now be used as technical specifications. First of all, because the latter can refer to both environmental and social labels, with the only obligation to accept equivalents, ${ }^{99}$ and social labels normally entail supply-chain considerations, such as minimum acceptable wages and work conditions.

Moreover, given the current wording of the technical specifications' definition in Directive $2014 / 24 / \mathrm{EU},{ }^{100}$ they can refer also to a certain process or production method even if not part of the material substance of the required work, service or supply, provided that they are linked to the

\footnotetext{
${ }^{97}$ Article 42, para 3, Directive 2014/24/EU. Article 60, para 3, Directive 2014/25/EU.

${ }_{98}^{98}$ Article 45, Directive 2014/24/EU and Article 64, Directive 2014/25/EU.

${ }^{99}$ Article 43, para 1, Directive 2014/24/EU. Article 61, para 1, Directive 2014/25/EU. Article 36, para 1, Directive 2014/23/EU.

${ }^{100}$ See Article 42, para 1, Directive 2014/24/EU.

100
} 
subject-matter of the contract and are proportionate to its value and objectives. According to Directive 2004/18/EU, simply requiring a fair trade label as a technical requirement, without specifically indicating its underlying specifications, was not allowed. ${ }^{101}$ However, today, under Directive 2014/24/EU, if all fair trade label's specifications are required, the mere reference to a certain fair trade label in the procurement documents would be allowed. ${ }^{102}$

Furthermore, under the 2014 rules, contracting authorities can exclude tenders not complying with wage provisions or other labour standards set out in collective agreements, national, EU or international law. ${ }^{103}$ In this respect, however, the Commission stated that wider social concerns, such as a fair trade or observance of non-legislative social considerations, are better integrated into contract performance clauses, while the CJEU held that they might be included into award criteria. ${ }^{104}$

Overall, contracting authorities should be able to integrate general social considerations also in technical specifications as tenders could be rejected in the case of non-compliance. Award criteria and contract performance clauses do not lead to the tenders' exclusion. Thus, the integration of social considerations would be less effective. In fact, if a tender does not meet a certain award criterion, it would merely fail to achieve marks under that criterion. If minimum scores are not required, that tender would still be considered as the most economically advantageous tender. Likewise, contract performance clauses merely 'constitute fixed objective requirements that have no impact on the assessment of tenders. ${ }^{105}$ Thus, both award criteria and contract performance clauses may be insufficient to effectively incorporate social considerations within public procurement procedures.

\subsubsection{Labels.}

The public sector is increasingly resorting to third-party verification of environmental and social performance levels through labels or certificates. As a consequence, available standards, labels and certifications are growing in number making it sometimes difficult to identify those actually independent, not closely linked or controlled by industry. ${ }^{106}$

In general terms, labels allow tenderers to prove that their products and/or services meet certain criteria and ease contracting authorities evaluation processes. As mentioned, labels or certificates can also be used to control compliance with social criteria, such as minimum labour conditions and ethical production methods. ${ }^{107}$ However, labels and certifications are less common in

${ }^{101}$ C-368/10, the Dutch Eco-Labels case, op. cit..

${ }^{102}$ In this respect see, among others, H Schebesta, 'EU Green Public Procurement Policy Modernisation Package, EcoLabelling and Framing Measure' in S Schoenmaekers, W Devroe, N Philipsen (eds), State Aid and Public Procurement in the European Union (Intersentia, 2014), 136.

${ }^{103}$ Articles 18, para 2 and 56, para 1, Directive 2014/24/EU. Articles 36, para 2 and 76, para 6, Directive 2014/25/EU. Recitals 55 and 58, Article 30 para 3, Directive 2014/23/EU.

${ }^{104}$ C-368/10, op. cit..

${ }^{105}$ Recital 104, Directive 2014/24/EU.

${ }^{106}$ On eco-labels see, among others, D C Dragos, B Neamtu, 'Sustainable Public Procurement in the EU: Experiences and Prospects', op. cit., 329. F Rubik, D Scheer, E StØ, P Strandbakken, 'Background: theoretical contributions, ecolabels and environmental policy' in F Rubik, P Frankl (eds), The Future of Eco-labelling: Making Environmental Product Information Systems More Effective (Greenleaf Publishing, 2005) 17. M Bleda, M Valente, 'Graded eco-labels: A demand-oriented approach to reduce pollution' [2009] Technological Forecasting \& Social Change, 512. H Schebesta, 'EU Green Public Procurement Policy Modernisation Package, Eco-Labelling and Framing Measure', $o p$. cit.. Buying Green! - A Handbook on Green Public Procurement, 2016, op. cit., 37.

${ }^{107}$ Article 43, Directive 2014/24/EU. 
the field of social value, with the exception of fair trade. Public procurement incorporating social concerns, in fact, tends to be more local, regional or national.

In public procurement, environmental and social labels can be used to:

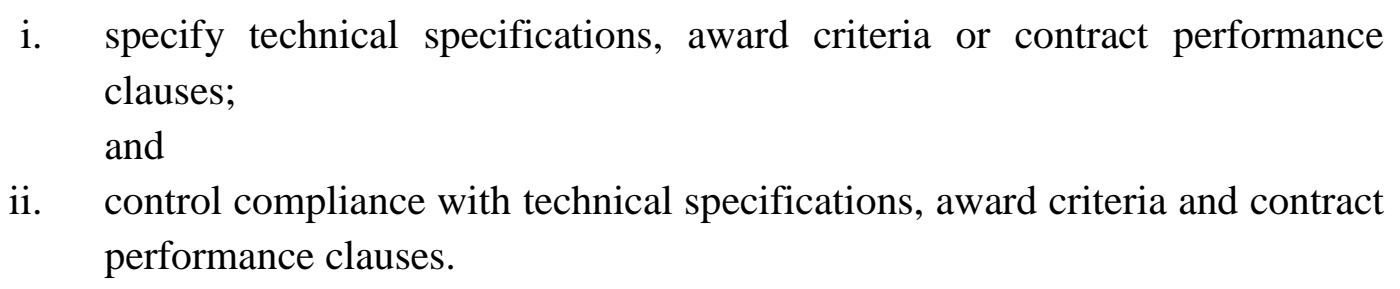

The existence of labels can help to lower the costs of proving compliance with environmental and/or social requirements. Contracting authorities can require specific labels to verify that works, services or suppliers correspond to the required characteristics. ${ }^{108}$ However, they have to accept equivalent labels. Tenderers can also refer to other means of proof, such as a technical dossier of the manufacturer, in case they cannot obtain that specific label or an equivalent one within the set time limits.

The development and alignment to the EU Eco-label and national eco-labels is part of the process towards EU green public procurement. ${ }^{109}$ The EU Eco-label Regulation provides for a voluntary scheme supporting products that have a high level of environmental performance. ${ }^{110}$ The use of eco-labels is encouraged in order to set boundaries to an unlimited creation of labelling schemes and to promote higher environmental performance standards in various sectors. ${ }^{111}$ Functional requirements can, in fact, be defined by reference to an eco-label. Products bearing an eco-label are presumed to be compliant with certain performance targets.

It may be argued that labels and certifications limit innovative solutions. The fact that labels are designed to refer to the state of art of performance in a specific sector may go against innovation. However, labels are frequently revised in order to reproduce the developments occurring in a certain field. Moreover, if a label not yet updated actually inhibits an innovative solution, the benefits of having a unique reference framework for sustainable goods and services, in terms of price reduction and larger availability, would balance the situation.

\subsubsection{Exclusion criteria.}

As in 2004, the new Directives provide for mandatory and discretionary grounds for tenderers' exclusion. Mandatory grounds relate to specific and serious offences, such as fraud or money laundering, which prohibit the award of a public contract for at least a certain period of time to an

\footnotetext{
${ }^{108}$ Article 43, para 1, Directive 2014/24/EU. Article 61, para 1, Directive 2014/25/EU. Article 36, para 1, Directive 2014/23/EU.

${ }^{109}$ H Karl, C Orwat, 'Environmental labelling in Europe: European and national tasks' [1999] Environmental Policy and Government, 214, 217. B Neamtu, D C Dragos, 'Sustainable Public Procurement: The Use of Eco-Labels' [2015] EPPPL, $1,11$.

${ }^{110}$ Regulation n. 66/2010 of the European Parliament and of the Council of 25 November 2009.

${ }^{111}$ H Schebesta, 'EU Green Public Procurement Policy Modernisation Package, Eco-Labelling and Framing Measure' op. cit., 138, 141. 
economic operator. ${ }^{112}$ Exclusions can only take place if there is a conviction by a final judgement for one of the offences specifically indicated in the text of the Directives. Mandatory exclusions are applied in any phase of the procurement procedure and contracting authorities can terminate a contract awarded to an economic operator that should have been excluded under a mandatory ground. Moreover, mandatory exclusion grounds may be exceptionally derogated in case of 'overriding reasons relating to the public interest such as public health or protection of the environment. ${ }^{, 13}$ In terms of sustainable development objectives, the mandatory exclusion ground that relates to the case of non-payment of tax or social security by the economic operator strengthens the integration of social considerations into the procurement process. Under the 2004 regime, it was only a discretionary ground of exclusion. Today, it is a mandatory one. However, it still has a limited effect. It does not apply if the economic operator executes the payment or agrees to pay the sums owed. ${ }^{114}$ Furthermore, a Member State may derogate from this ground of exclusion if it is disproportionate. For instance, when there are small amounts of taxes or social securities not paid. ${ }^{115}$ The maximum exclusion period that can be set is of five years from the date of the final judgement. ${ }^{116}$

Discretionary exclusion grounds are, instead, more extensive and specifically embrace the case of violation of applicable obligations in 'the fields of environmental, social and labour law established by Union law, national law, collective agreements or by the international environmental, social and labour law provisions. ${ }^{117}$ Member States are also allowed to make these discretionary exclusion grounds become mandatory when implementing the Directives in their national law. They have to indicate the maximum period during which the exclusion will apply if there is no indication in this respect in the judgment against the economic operator. The maximum exclusion period is of three years from the relevant event in the case of discretionary grounds. No specific exclusion period is foreseen for the case of non-payment of taxes or social securities. The mentioned periods are included within the possibility provided for by Article 57, para 6, Directive 2014/24/EU. Economic operators - even if there is an exclusion ground - can demonstrate that they are taking actions that prove their reliability.

Under the 2014 Directives, contracting authorities can exclude economic operators in the case of their defective prior performance of a public contract, which may occur also in the field of environmental and/or social sustainability. However, the following cumulative conditions have to be satisfied. ${ }^{118}$ The deficiencies have to be significant, continuative and referring to a substantive requirement of the previous contract. Moreover, they have to affect a public, utility, or concession

\footnotetext{
112 Article 57, Directive 2014/24/EU. Article 80, para 1, Directive 2014/25/EU. Article 38, paras 4 and 5, Directive 2014/23/EU. A Sanchez Graells, 'Exclusion, Qualitative Selection and Short-listing in the New Public Sector Procurement Directive 2014/24', op. cit., 105.

113 Article 57, para 3, Directive 2014/24/EU. Article 38, para 6, Directive 2014/23/EU.

${ }^{114}$ Article 57, para 2, Directive 2014/24/EU. Foremost, see the joined cases C Joined cases C-226/04 and C-228/04, La Cascina Soc. coop. arl and Zilch Srl v Ministero della Difesa and Others (C-226/04) and Consorzio G. f. M. v Ministero della Difesa and La Cascina Soc. coop. arl (C-228/04), [2006] I-01347.

${ }^{115}$ In this respect, it has to be noted that the CJEU held that this exclusion ground based on a very small-unpaid amount is not disproportionate. See C-358/12, Consorzio Stabile Libor Lavori Pubblici v Comune di Milano, published in the electronic Reports of Cases (Court Reports - general). A Brown, 'Is a National Law Requiring the Exclusion of Bidders for Non-Payment of Social Security Contributions Exceeding 100 euros Compatible with the EU Treaty and the Principle of Proportionality? Case C-358/12 Consorzio Stabile Libor Lavori Pubblici v Comune di Milano' [2014] PPLR, 165, 170.

${ }^{116}$ Article 57, para 7, Directive 2014/24/EU.

117 Articles 18, para 2 and 57, para 4, Directive 2014/24/EU. Articles 30, para 3 and 38, para 7, Directive 2014/23/EU.

${ }_{118}$ Article 57, para 4, letter g), Directive 2014/24/EU.
} 103 
contract leading to an early termination, damages or other similar circumstance. ${ }^{119}$ Undoubtedly, such conditions limit the possibility of excluding an economic operator in the case of defective prior performance. This is why - given such restrictions - exclusions of tenderers with poor socioenvironmental records can be more easily achieved through qualitative selection criteria. Another discretionary exclusion basis that can allow the integration of social considerations into procurement procedures is the one concerning the 'grave professional misconduct' of a tenderer, which may render its reliability questionable. ${ }^{120}$ Professional misconduct may result from using hidden employment, from treating workers non-equally or from non-complying with health and safety provisions. ${ }^{121}$ However, the identification of what 'grave professional misconduct' exactly entails is left to Member States' discretion.

\subsubsection{Criteria for qualitative selection.}

In general terms, criteria for qualitative selection, or selection criteria, allow contracting authorities to identify suitable tenderers according to their needs and reduce the number of candidates to be invited to tender. They focus on the past and/or on the present situation of tenderers, while technical specifications and award criteria refer to what will be performed in the future. ${ }^{122}$ Since 2014 , this is no longer completely true because contracting authorities can assess staff experience at the award phase. ${ }^{123}$ Article 67, para 2, letter b), Directive 2014/24/EU states that award criteria may cover the 'organisation, qualification and experience of staff assigned to performing the contract, where the quality of the staff assigned can have a significant impact on the level of performance of the contract.' In any case, selection criteria must relate to the subject matter of the contract and be proportionate to it. The general headings under which selection criteria can be structured are (i) suitability to pursue the professional activity, (ii) economic and financial standing and (iii) technical and professional ability. Under Directive 2014/24/EU, the list of permissible selection criteria is an exhaustive one, ${ }^{124}$ while pursuant to Directives 2014/25/EU and 2014/23/EU there is a greater flexibility concerning the choice of selection criteria. ${ }^{125}$

Selection criteria have a large potential in securing sustainable development objectives. Contracting authorities can decide to take into account, when evaluating selection criteria, tenderers' past performance of environmental and/or social obligations. Moreover, contracting authorities can allow scope for sustainability considerations if they set selection criteria - under the general heading of technical and professional ability - that address tenderers' human and technical resources, skills, efficiency, experience and reliability in the field of environmental sustainability. Hence, if a contract requires specific knowledge in the environmental field, a specific skill may be

\footnotetext{
${ }_{119}$ Article 57, para 4, Directive 2014/24/EU. Article 38, para 7, Directive 2014/23/EU.

${ }^{120}$ Article 57, para 4, letter c), Directive 2014/24/EU. Article 80, Directive 2014/25/EU. Article 38, para 7, letter c), Directive 2014/23/EU.

${ }^{121}$ Point 1.3.1, Interpretative Communication of the Commission on the Community law applicable to Public Procurement and the possibilities for integrating social considerations into Public Procurement (2001/C 333/08) COM (2001) 566 final.

${ }^{122}$ See, C-532/06, Emm. G. Lianakis AE, Sima Anonymi Techniki Etaireia Meleton kai Epivlepseon and Nikolaos Vlachopoulos v Dimos Alexandroupolis and Others, [2008] I-00251. T Kotsonis, 'The Nature of Award Criteria and the Subsequent Stipulation of Weightings and Sub-criteria: Lianakis v Dimos Alexandroupolis (C-532/06)' [2008] PPLR, 128,134

${ }^{123}$ See, for instance, Article 67, para 2, letter b), Directive 2014/24/EU.

${ }^{124}$ Articles 58, para 1, Directive 2014/24/EU.

${ }^{125}$ Articles 78, Directive 2014/25/EU. Article 38, Directive 2014/23/EU. 104
} 
used as a selection criterion allowing the contracting authority to identify the most suitable candidates. In addition, tenderers' corporate social responsibility may be referred to if it helps to prove their ability to perform the contract. ${ }^{126}$

Moreover, selection criteria may allow scope for sustainability when they require evidence of quality assurance and environmental management systems. Evidence that can be provided by tenderers may range from products' samples, to supply chain management or tracking systems. Economic operators can also rely on the capacity of others in order to prove their compliance with selection criteria, irrespective of the link existing between them. ${ }^{127}$ In this case, the contracting authority has to verify that the other entity complies with the mandatory exclusion criteria and, in the case of non-compliance, require its replacement. Furthermore, the economic operator has to prove that it will have access to such capacity during the performance of the contract. ${ }^{128}$

Finally, it can be mentioned that the 2014 regime provides for a greater possibility to reserve contracts to companies that employ disabled or disadvantaged workers. ${ }^{129}$ Hence, social considerations may be integrated in public purchasing also in this way.

\subsubsection{Means of proof.}

Economic operators can use the European Single Procurement Document (hereinafter ESPD) to demonstrate compliance with exclusion and selection criteria. The ESPD is a self-declaration form designed to provide an electronic and standard model that can be easily updated. Contracting authorities have to accept the ESPD as 'preliminary evidence in replacement' of certificates issued by other public authorities or third parties. ${ }^{130}$ The ESPD indicates that supporting documents can be provided 'without delay' by the economic operator and specifies from which databases they can be retrieved. ${ }^{131}$ Supporting documents may be required at any time unless they are freely available in national databases. The winning bidder is, instead, obliged to provide them along with the ESPD. ${ }^{132}$ Article 60, Directive 2014/24/EU, indicates which certificates and declarations can be used as means of proof to demonstrate compliance with exclusion and selection criteria.

Under the 2014 rules, room for sustainable development considerations can be found also when dealing with means of proof. For instance, Article 62 of Directive 2014/24/EU, addresses the use of quality assurance standards and environmental management systems at the selection phase. ${ }^{133}$ Contracting authorities can request certification from independent entities in order to attest

\footnotetext{
${ }^{126}$ Point 1.3.2, Interpretative Communication of the Commission on the Community law applicable to Public Procurement and the possibilities for integrating social considerations into Public Procurement (2001/C 333/08) COM (2001) 566 final.

${ }^{127}$ Article 63, Directive 2014/24/EU. Article 79, Directive 2014/25/EU. Article 38, para 2, Directive 2014/23/EU.

${ }^{128}$ In this respect, see C-389/92, Ballast Nedam Groep NV v Belgian State, 1994 I-01289. C-176/98, Holst Italia SpA v Comune di Cagliari, [1999] I-08607. C-314/01, Siemens AG Österreich and ARGE Telekom \& Partner v Hauptverband der österreichischen Sozialversicherungsträger, [2004] I-02549. C-399/05, Commission of the European Communities $v$ Hellenic Republic, [2007] I-00101. C-95/10, Strong Segurança SA v Município de Sintra and Securitas-Serviços e Tecnologia de Segurança, [2011] I-01865. C-218/11, Észak-dunántúli Környezetvédelmi és Vízügyi Igazgatóság (Édukövízig) and Hochtief Construction AG Magyarországi Fióktelepe v Közbeszerzések Tanácsa Közbeszerzési Döntöbizottság, published in the electronic Reports of Cases (Court Reports - general).

${ }^{129}$ Article 20, Directive 2014/24/EU. Article 38, Directive 2014/25/EU. Article 24, Directive 2014/23/EU.

${ }^{130}$ Article 59, para 1, Directive 2014/24/EU.

${ }^{131}$ Article 59, para 1, Directive 2014/24/EU. Article 61 requires contracting authorities to primarily consult the on-line repository of certificates (e-Certis).

${ }^{132}$ Article 59, para 4, Directive 2014/24/EU.

${ }^{133}$ See also Article 81, Directive 2014/25/EU.

105
} 
tenderers' compliance with sustainable standards or systems. Nonetheless, they also still have to accept equivalent certifications. Moreover, the scope for sustainable objectives can be secured through environmental management systems that can now be requested in all public contracts, while previously such a possibility was limited only to services and works contracts. Furthermore, the possibility to request third-party labels may now also include and refer to labels concerning social and other characteristics, in addition to eco-labels. ${ }^{134}$ In this respect, it can be recalled that the increased number of existing labels makes it sometimes difficult to identify independent and objective labels.

In principle, contracting authorities cannot ask for a specific label. Nonetheless, when drafting technical specifications, award criteria and contract performance clauses, they can specifically refer to one - that for instance attests the environmental sustainability of a product - if the following conditions, set out in Article 43, para 1, Directive 2014/24/EU, are met.

'a) the label requirements only concern criteria which are linked to the subject-matter of the contract and are appropriate to define characteristics of the works, supplies or services that are the subject-matter of the contract; (b) the label requirements are based on objectively verifiable and nondiscriminatory criteria;

(c) the labels are established in an open and transparent procedure in which all relevant stakeholders, including government bodies, consumers, social partners, manufacturers, distributors and non-governmental organisations, may participate;

(d) the labels are accessible to all interested parties;

(e) the label requirements are set by a third party over which the economic operator applying for the label cannot exercise a decisive influence.'

In any case, equivalent labels have to be accepted by contracting authorities. In this respect, it can be mentioned that economic operators now have limited possibilities to rely on internal technical dossiers, which can only be referred to in case of unavailability of the label for reasons not attributable to the tenderer.

Finally, it can be noted that contracting authorities can also request test reports and certification issued by conformity evaluation bodies in order to obtain evidence of compliance with technical specifications, award criteria or contract clauses. ${ }^{135}$ These bodies play a crucial role in the implementation of the principle of mutual recognition within the EU and are accredited under Regulation n. 765/2008 to carry out adjustment, testing, verification and certification of products subject to harmonized standards, including the CE mark.

\subsubsection{Award criteria.}

One of the most significant achievements of the 2014 reform has been the choice of the "most economically advantageous tender' (hereinafter MEAT) as criterion for any award decision, thereby

\footnotetext{
${ }^{134}$ Articles 43 and 44, Directive 2014/24/EU. Articles 61 and 62, Directive 2014/25/EU.

${ }^{135}$ Article 44, para 1, Directive 2014/24/EU. 106
} 
formally eliminating the previous distinction between the MEAT and the lowest price. When this decision was taken, the European Parliament during a press release stated that:

\begin{abstract}
'Thanks to the new criterion of the 'most economically advantageous tender' in the award procedure, public authorities will be able to put more emphasis on quality, environmental considerations, social aspects or innovation while still taking into account the price and life-cycle-costs of what is procured. 136
\end{abstract}

Moreover, Mr Tarabella ${ }^{137}$ pointed out that

'The new criteria will put an end to the dictatorship of the lowest price and once again make quality the central issue.'

Indeed the MEAT is an award criterion capable of accommodating innovative, environmental and social issues, allowing the actual integration of sustainable considerations within the procurement process. ${ }^{138}$ However, the MEAT must still be identified by looking at the price or cost. Thus, the lowest price criterion is somehow still present in the expression 'price or cost' of Article 67, para 2, Directive 2014/24/EU. What is remarkable is that the identification of the MEAT - on the basis of price or cost - entails the application of a cost-effectiveness approach, such as Life Cycle Costs (hereinafter LCC) ${ }^{139}$ and may include the best price-quality ratio. The latter may be evaluated on the basis of qualitative, environmental and/or social criteria linked to the subject-matter of the contract. Such criteria may refer to quality, technical merit, aesthetic and functional features, accessibility, design for all users, social, environmental and innovative characteristics and trading conditions of the goods, works, or services to be purchased. Moreover, the way in which contracting authorities decide to weigh costs and qualitative criteria may actually support the inclusion of sustainable considerations in the procurement process. Contracting authorities have to clarify which approach they will follow to verify tenderers' performance. Therefore, they have to state whether they will refer to economic operators' statements or third-party evidence, such as labels, certifications or test reports.

As mentioned, the MEAT criterion implies that contracting authorities cannot exclude price or cost from their evaluation. Public bodies may still adopt the lowest price criterion if deemed more adequate for the award of a certain public contract. However, when implementing the 2014 Directives, Member States may choose to limit the use of lowest-price or lowest-cost awards. ${ }^{140}$ Thus, Member States may exclude or restrict the use of price or cost, but cannot impose the use of

\footnotetext{
${ }^{136}$ New EU-procurement rules to ensure better quality and value for money, European Parliament press release, 2014, available at

http://www.europarl.europa.eu/news/en/news-room/20140110IPR32386/New-EU-procurement-rules-to-ensure-betterquality-and-value-for-money.

${ }^{137}$ Belgian politician and member of the EU Parliament.

${ }^{138}$ D C Dragos, B Neamtu, 'Sustainable public procurement in the EU: Experiences and Prospects', op. cit., 318. M Burgi, B Brandmeier, 'Quality as an Interacting Award Criterion under Current and Future EU-Law' [2014] EPPPL. S Arrowsmith, P Kunzlik, Social and Environmental Policies in EC Procurement Law: New Directives and New Directions, op. cit.. R Caranta, M Trybus, The Law of Green and Social Procurement, op. cit.. P Bordalo Faustino, 'Award criteria in the new EU Directive on public procurement' [2014] PPLR, 124, 133.

${ }^{139}$ See below, paragraph 3.6.6.

${ }^{140}$ Article 67, para 2, Directive 2014/24/EU.
} 
price and cost only. This view seems to be supported by the increasing tendency to limit - if not eliminate - the use of the lowest price criterion promoting greater attention to quality considerations. $^{141}$

Overall, award criteria (i) must be linked to the subject matter of the contract, (ii) be clearly indicated in the procurement documents and (iii) should not allow an unrestricted freedom of choice on the public authority. The requirement of the link with the subject-matter of the contract means that award criteria have to relate to the works, supplies or services to be purchased in any respect and in any phase of their life cycle. ${ }^{142}$ Award criteria cannot refer to the general practices of tenderers, but only to the specific goods, services or works to be provided under the contract. ${ }^{143}$ Recital 97, Directive 2014/24/EU, clearly explains that the requirement of the link with the subjectmatter excludes criteria that refer to the general corporate policy of tenderers. ${ }^{144}$ Thus, within these limits, contracting authorities have a considerable leeway in the formulation, weighting and performance evaluation against award criteria, which may include sustainable considerations.

Such broad understanding of the requirement of the link with the subject-matter of the contract allows the inclusion of environmental, social and innovative considerations. Recital 67, para 3, Directive 2014/24/EU, highlights that:

\begin{abstract}
'Award criteria shall be considered to be linked to the subject-matter of the public contract where they relate to the works, supplies or services to be provided under that contract in any respect and at any stage of their life cycle, including factors involved in: (a) the specific process of production, provision or trading of those works, supplies or services; or (b) a specific process for another stage of their life cycle, even where such factors do not form part of their material substance.'
\end{abstract}

Therefore, award criteria may not only refer to the technical characteristics of the works, supplies or services to be provided under the contract, but can also include various elements related in any respect and at any stage of the life-cycle of the works, supplies or services to be purchased. In addition, the so-called technical characteristics may cover different aspects of the works, supplies or services, such as their process, method of production, provision, specific stage of their life-cycle, even if not part of their material substance. Overall, this flexible approach to the requirement of the link with the subject-matter of the contract seeks to ease and promote the integration of environmental, social and innovative award criteria under the MEAT. ${ }^{145}$

Moreover, as in the case of technical specifications, award criteria have the ability to address sustainable considerations through the application of the life-cycle costing approach, which entails the consideration of the entire life-cycle of a good, service or work. Specific rules on LCC have been introduced in 2014. They allow a significant flexibility in the range of cost factors that can be covered by LCC. Costs related to the purchase, use, maintenance or end of life of the goods,

\footnotetext{
${ }^{141}$ See, for instance, Recital 90, para 2, Directive 2014/24/EU. See among others, S Arrowsmith, The Law of Public and Utilities Procurement, op. cit., 761. A Semple, A Practical Guide to Public Procurement, op. cit., 11, 115.

${ }_{142}$ Article 67, para 3, Directive 2014/24/EU. Article 82, para 3, Directive 2014/25/EU.

${ }^{143}$ A Semple, 'Reform of EU Procurement Directives and WTO GPA: Forward Steps for Sustainability,' op. cit..

${ }^{144}$ See also Recital 104, Directive 2014/24/EU.

${ }^{145}$ See, inter alia, P B Faustino, 'Award Criteria in the New EU Directive on Public Procurement', op. cit., 131. A Semple, A Practical Guide to Public Procurement, op. cit., 186. 
services or works to be purchased may be included. ${ }^{146}$ LCC may also include costs allocated to environmental externalities, such as greenhouse gas emissions. ${ }^{147}$ Social externalities are not yet included. However, Recital 96 of Directive 2014/24/EU, provides that 'the feasibility of [...] a common methodology on social life cycle costing should be examined, taking into account existing methodologies such as the Guidelines for Social Life Cycle Assessment of Products adopted within the framework of the United Nations Environment Programme.'

Other significant 2014 changes, in terms of the inclusion of socio-environmental objectives, are the possibility of taking into account staff experience of tenderers as well as the production processes or trade of goods, services or works. Staff qualification and skills can be assessed if they have 'a significant impact on the level of performance of the contract' and they were not already evaluated at the selection phase. ${ }^{148}$ Staff qualification and skills may indeed be important in the performance of many public contracts delivering public infrastructure or services in a sustainable way. ${ }^{149}$ Moreover, following the Dutch Coffee case, ${ }^{150}$ award criteria may refer to a certain production process, trading or provision method of the goods, services or works to be purchased. In addition, they may refer to a certain process for another phase of their life-cycle, even if such aspects are not part of their material substance. In other words, the 2014 regime explicitly provides for the possibility of integrating environmental features, innovative characteristics and trading conditions in award criteria. Recital 99 of Directive 2014/24/EU, provides guidance on the social considerations that can be integrated within award criteria or performance clauses. These can be social concerns concerning health protection and social integration of disadvantaged people or persons of vulnerable groups. For instance, the employment of long-term job seekers and the implementation of training measures for unemployed or young people. Anyway, as held before, the key requirement for social and innovative award criteria is always the link with the subject-matter of the contract.

As seen, Article 67, para 2, Directive 2014/24/EU, states that the MEAT has to be identified on the basis of the price or cost, using a cost-effectiveness approach such as the LCC. One of the most important changes of the 2014 reform is the explicit reference to the concept of LCC in the text of the Directives. ${ }^{151}$ LCC is a tool that allows the assessment of the costs of a product, work or service throughout its life-cycle. ${ }^{152}$ In fact, the purchase price alone does not cover all the financial and non-financial benefits attainable through sustainable goods, work or services and accumulated during its operation, use, maintenance and disposal.

\footnotetext{
${ }_{146}$ Article 68, para 1, Directive 2014/24/EU. Article 83, para 1, 2014/25/EU.

${ }_{147}$ Article 68, Directive 2014/24/EU. Article 83, Directive 2014/25/EU.

${ }_{148}$ Article 67, para 2, letter b), Annex XII, Part II, point f), Directive 2014/24/EU. Article 82, para 2, letter b) Directive 2014/25/EU.

${ }^{149}$ C-532/06, Emm. G. Lianakis AE, Sima Anonymi Techniki Etaireia Meleton kai Epivlepseon and Nikolaos Vlachopoulos v Dimos Alexandroupolis and Others, [2008] I-00251. C-199/07, Commission of the European Communities v Hellenic Republic, [2009] I-10669.

${ }^{150}$ C-368/10, op. cit..

151 Article 68, Directive 2014/24/EU. LCC can be used also when contracting authorities opt for the lowest price/cost criteria.

${ }^{152}$ W Scharnhorst, 'Life Cycle Assessment in the Telecommunication Industry: A Review', op. cit., 75, 86. D Dragos, B Neamtu, 'Sustainable Public Procurement: Life-cycle Costing in the New EU Directive Proposal' [2013] EPPPL, 19, 30. P Kunzlik, 'From suspect practice to market-based instrument: policy alignment and the evolution of EU law's approach to "green" public procurement' [2013] PPLR, 97, 115. A Semple, A Practical Guide to Public Procurement, op. cit., 190. R Caranta, 'Helping Public Procurement Go Green: The Role of International Organisations' [2013] EPPPL. 
The LCC approach covers costs borne by end-users, contracting authorities and the environment, which may range from costs related to consumption and maintenance, to end of life aspects, such as collection or recycling. The 2014 Directives set out the limits within which LCC can be applied in procurement and, in particular, they provide for the inclusion of environmental externalities in the evaluation of costs. ${ }^{153} \mathrm{LCC}$ can also, in fact, take into account costs associated with environmental externalities related to the product, service or work to be purchased under a certain contract during its life cycle, provided that their value can be monetised. These may be costs of greenhouse gas emissions or other pollutant and climate change mitigation costs. ${ }^{154}$ When using the LCC approach, contracting authorities have to specify which method they will use to calculate LCC in the procurement documents and indicate the data that tenderers have to submit. Such method must be objectively verifiable and non-discriminatory. Recital 96, Directive 2014/24/EU, explains that

"the notion of life-cycle costing includes all costs over the life-cycle of
works, supplies or services. This means internal costs, such as research to
be carried out, development, production, transport, use, maintenance and
end-of-life disposal costs but can also include costs imputed to
environmental externalities, such as pollution caused by extraction of the
raw materials used in the product or caused by the product itself or its
manufacturing, provided they can be monetized and monitored."

Article 68, para 1 of Directive 2014/24/EU provides for a sample list of internal costs covered by $\mathrm{LCC}^{155}$ and an indication of the external costs generated during the life-cycle of a certain product, service or work. ${ }^{156}$ Scope for sustainability is explicitly allowed when external costs related to the delivered work, product or service are covered, thus, when externalities are internalized and associated to a financial value. Article 68 of Directive 2014/24/EU specifically refers only to environmental externalities, such as those generated, for instance, during transport. Other kinds of externalities, such as social ones, are not yet included within the LCC approach. ${ }^{157}$ Even though the European Parliament called for an inclusion of social externalities into LCC, they were not referred to in the final text of the 2014 Directives, thereby hindering the full potential of LCC. The actual feasibility of a social LCC is still under scrutiny. ${ }^{158}$ A social LCC approach would mean taking into account, for instance, labour conditions, equal opportunities and accessibility criteria. Anyway, if

\footnotetext{
153 The expression environmental externalities is an economic concept that refers to the uncompensated impacts of production and consumption (outside the market mechanism) that have an effect on consumers and on private sector costs. See, D C Dragos, B Neamtu, 'Sustainable public procurement in the EU: Experiences and Prospects', op. cit., 326.

${ }_{154}^{15}$ Article 68, para 1, letter b), Directive 2014/24/EU. Article 83, para 1, letter b), Directive 2014/25/EU.

155 Article 68, para 1, letter a), Directive 2014/24/EU: (i) costs relating to acquisitions; (ii) costs of use, such as the consumption of energy and other resources; (iii) maintenance costs; (iv) end of life costs, such as collection and recycling costs.

${ }_{156}$ Such costs may refer to the costs of greenhouse gas emissions, other pollutant emissions and climate change mitigation costs. Article 68, para 1, letter a), Directive 2014/24/EU.

${ }^{157}$ D C Dragos, B Neamtu, 'Sustainable public procurement in the EU: Experiences and Prospects', op. cit., 25.

158 See, for instance, T E Swarr, 'Societal Life Cycle Assessment - Could You Repeat The Question?' [2009] International Journal Life Cycle Assessment, 285, 289. R Grießhammer, C Benoît, L C Dreyer, A Flysjö, 'Feasibility Study: Integration of Social Aspects into LCA' [2006] available at http://www.saiplatform.org/uploads/Library/UNEPSETACLifeCycleInitiativeTFonSocialIssues-FeasibilityStudy.pdf. A Jørgensen, A Le Bocq, L Nazarkina, M Hauschild, 'Methodologies for Social Life Cycle Assessment' [2008] International Journal of Life Cycle Assessment, $96,103$. 110
} 
public authorities decide to use a cost-effectiveness approach other than the LCC, considerations of any kind, including social ones, could be included. LCC is, in fact, just one of the possible costeffectiveness approaches that can be used by contracting authorities. The public sector is free to choose any cost-effectiveness approach to evaluate the cost element of the MEAT. ${ }^{159}$ In any case, social concerns should be directly or indirectly linked with the product, service or work to be purchased and their monetary value should be measurable, ${ }^{160}$ as monetisation is a requirement for any cost-effectiveness approach. Thus, their inclusion would be possible, yet challenging.

Article 68, para 3 of Directive 2014/24/EU provides that if a common method of LCC calculation becomes mandatory at EU level, such a method has to be applied for the assessment of life-cycle costs. Currently the only common and mandatory EU methodology for calculating LCC is the one set out in the Clean Vehicles Directive. ${ }^{161}$ According to this Directive, contracting authorities must consider energy consumption and emissions when purchasing road transport vehicles, for instance, by setting a cost to these elements in the evaluation of tenders. The Annex to the Directive provides for a set of costs to be applied so that emissions can be priced and included in the evaluation and comparison of bids. Higher costs may be assigned, up to a maximum of two times the indicated values. ${ }^{162}$ The Directive also provides for values on the energy content of different fuel types and the lifetime mileage of various vehicles. A series of LCC tools and methods are anyway available for the purchase of certain categories of goods, services and works ${ }^{163}$ and contracting authorities can develop and adopt their own, provided that it complies with the conditions set out in the 2014 Directives. ${ }^{164}$

\subsubsection{Award criteria vs technical specifications.}

Given the above, the following points can be specified in order to distinguish the role played by award criteria and technical specifications in the integration of socio-environmental objectives within public contracts. There are specific rules governing the way in which technical specifications can be expressed and contracting authorities must verify tenders' compliance with such conditions. As opposed to technical specifications, award criteria are not governed by the same degree of detail. They have to be defined in a clear and precise way and have to be accompanied by specifications that allow the verification of the information provided by economic operators in order to check how well bids meet the set award criteria. Moreover, technical specifications are minimum mandatory requirements applied to all economic operators. Thus, if there is a certain degree of knowledge on what the private sector can offer, they can effectively address, for instance, environmental aspects essential to the contract. Award criteria, instead, allow contracting authorities to distinguish tenders

\footnotetext{
${ }^{159}$ See the Non-paper prepared by the Commission services, DG Internal Market, on Cluster 2, Strategic use of public procurement, January 20, 2012, available at http://register.consilium.europa.eu/doc/srv?l=EN\&f=ST\%205369\%202012\%20INIT.

D C Dragos, B Neamtu, 'Sustainable public procurement in the EU: Experiences and Prospects', op. cit., 324.

${ }^{160}$ Article 67, para 1, letter b), of the Proposal for a Directive on Public Procurement, not included into the final 2014 text.

${ }^{161}$ Directive 2009/33/EC of the European Parliament and of the Council of 23 April 2009 on the promotion of clean and energy-efficient road transport vehicles.

${ }_{162}$ Article 6, para 1, letter c), Directive 2009/33/EC.

${ }^{163}$ For instance, the National Agency for Public Procurement in Sweden developed several product-specific LCC calculation tools that are available on-line. In addition, The SMART SPP project elaborated and tested a tool for contracting authorities to evaluate $\mathrm{LCC}$ and $\mathrm{CO}_{2}$ emissions and compare bids, see http://www.smart-spp.eu/guidance.

${ }^{164}$ Recital 96, Directive 2014/24/EU.
} 
upon environmental performance and can be used even if there is no prior knowledge on the minimum or maximum level of such performance. Furthermore, technical specifications may cover minimum requirements with regard to any or all of the elements affecting, for instance, the environmental footprint of a service, such as the choice of vehicles and/or routes, methods for separating, collecting or separating waste. Award criteria are, instead, more adequate to analyse the overall impact of the methods proposed by the economic operators.

Finally, it can be hereby mentioned that contracting authorities are - remarkably - obliged to reject abnormally low tenders that do not comply with environmental, social or labour law. ${ }^{165}$ The 2014 reform, in fact, opens the way - also in this respect - to the use of public purchasing as a tool to promote the enforcement of social, labour and environmental law. Thus, enhancing the possibility to use procurement to achieve social and environmental targets. ${ }^{166}$ Specifically, contracting authorities may decide not to award a public contract to the economic operator submitting the MEAT if they establish that the tender does not comply with the relevant obligations in the field of environmental, social and labour law set by EU, domestic law and collective agreements. Additionally, this may happen if the tender does not comply with obligations arising out international environmental, social and labour law provisions indicated in Annex X, Directive 2014/24/EU. ${ }^{167}$

\subsubsection{Contract performance clauses.}

The 2014 Directives explicitly acknowledge that contract performance clauses can include social and environmental requirements. ${ }^{168}$ They clearly state that contracting authorities may lay down special contractual performance conditions that include economic, innovation-related, environmental, social or employment-related considerations. ${ }^{169}$ These are referred to with the term 'special conditions' and have to be indicated in the call for competition or in the procurement documents. The expression 'special conditions' has not been defined, however. Specific examples are provided in text of the Directives along with the requirement to monitor compliance with such conditions. $^{170}$

Social considerations can more easily be integrated into contract performance clauses. ${ }^{171}$ Contract performance conditions may, in fact, - for instance - refer to the purchase of products from small-scale producers in developing countries at favourable trading standards (fair trade) or to measures aiming at the protection of health of the staff involved in the performance of the contract. Moreover, they can require compliance with ILO and human rights conventions. Contractual

\footnotetext{
${ }^{165}$ Article 69, para 3, Directive 2014/24/EU. Article 84, para 3, Directive 2014/25/EU. On the rejection of abnormally low tenders see, among others, A Semple, A Practical Guide to Public Procurement, op. cit., 117. A Sanchez Graells, 'Rejection of Abnormally Low and Non-Compliant Tenders in EU Public Procurement: A Comparative View on Selected Jurisdictions' in M Comba, S Treumer (eds), Award of Contracts in EU Procurement, European Procurement Law Series (DJØF, 2013) 289, 293.

${ }^{166}$ A Sanchez Graells, 'Exclusion, Qualitative Selection and Short-listing in the New Public Sector Procurement Directive 2014/24', op. cit., 101.

${ }^{167}$ See Article 18, para 2, Directive 2014/24/EU.

${ }_{168}$ Article 70, Directive 2014/24/EU. Article 87, Directive 2014/25/EU. Recitals 64 to 66, Directive 2014/23/EU.

169 Article 70, Directive 2014/24/EU. Article 87, Directive 2014/25/EU. Recitals 64 to 66, Directive 2014/23/EU.

${ }^{170}$ See, for instance, Article 56, para 1, Directive 2014/24/EU.

${ }^{171}$ Buying Social, A Guide to Taking Account of Social Considerations in Public Procurement, European Commission Directorate-General for Employment, Social Affairs and Equal Opportunities, 2010, 43, 44. 
conditions may also refer to environmental considerations, such as the re-use of products or of packaging or, in general, the delivery of products in an environmental friendly way.

Overall, contractual conditions have the potential of stressing the socio-environmental commitments of economic operators, which are normally safeguarded by adequate remedies in case of breach. Contract terms are, in fact, usually accompanied by penalties or incentives - in terms of bonus payments - to encourage the achievement of high performance standards. ${ }^{172}$ Thus, contract performance clauses can effectively allow scope for sustainable development objectives as they give contracting authorities the possibility to set conditions that incorporate also socioenvironmental considerations. The 2004 Directives already envisaged such a possibility. ${ }^{173}$ However, the 2014 rules added the requirement of the link with the subject-matter of the contract. This means that contract performance clauses setting, for instance, corporate responsibility requirements are not allowed. Thus, an economic operator cannot be asked to participate in a carbon-offsetting scheme or to make its investments in a certain territory outside the scope of a specific contract. Instead, it can be asked to offset carbon emissions during the delivery of the goods or services under a certain contract or to offer specific social benefits related to the contract performance, such as traineeships or training programs.

\subsubsection{Contract review clauses.}

Public contracts may include review clauses allowing adjustments. For instance, review clauses may secure modifications of the way in which certain services or products are delivered in order to improve or update their sustainable characteristics. However, they have to meet the following three conditions. ${ }^{174}$ First of all, they have to be indicated in the initial procurement documents. In multiphase procedures - such as the competitive dialogue - this means that the need for review clauses has to be indicated in the relevant procurement documents, hence, in those setting out contract terms. The second condition requires that review clauses have to be clear, precise, unequivocal and indicate the scope and nature of the potential amendments or options as well as any circumstances in which they may be used. Thus, for instance, the frequency with which the modifications may become necessary and how their value will be assessed, has to be specified. A high level of forecast is, thus, necessary to draft adequate review clauses. Lastly, review clauses may not alter the overall nature of the public contract.

\section{The scope for sustainable development concerns in public-private partnerships.}

The previous paragraphs examined the actual spaces for social and environmental considerations recognised by the 2014 public procurement Directives into tender procedures for the award of public contracts. The following paragraphs will narrow down the analysis and offer insights on how sustainable development objectives can be integrated into tender procedures for the award of a specific type of public contract, PPPs. It will be discussed how the planning, award, structure, operation and management of these public-private collaborations may be shaped upon sustainable considerations. Hence, the role played by the various procurement phases in the inclusion of

\footnotetext{
${ }^{172}$ A Semple, 'Reform of EU Procurement Directives and WTO GPA: Forward Steps for Sustainability', op. cit.

${ }^{173}$ Article 26, Directive 2004/18/EC. Article 38, Directive 2004/17/EC.

${ }^{174}$ Article 72, para 1, letter a), Directive 2014/24/EU.
} 
sustainable development concerns into PPPs will be first of all highlighted. Then, it will be briefly seen how public sector financial management choices may influence the integration of socioenvironmental concerns in these complex, long-term public contracts.

\subsection{The procurement process: overview.}

PPPs have been defined as arrangements that combine government or public resources with those of private entities in order to deliver societal goals. ${ }^{175}$ Other authors have argued that PPPs can answer general economic growth and sustainable issues that States and local public entities today have to face. ${ }^{176}$ Beyond these and others theoretical definitions and statements, it is, however, important to have an understanding of how PPPs can concretely integrate and promote sustainable development goals.

The particular features of PPPs do have the ability of effectively supporting the achievement of also socio-environmental objectives. Nonetheless, there is no universal, a priori or correct formula for the structuring of sustainable PPPs. In general terms, PPPs which are planned, operated and managed in a sustainable way deliver a better allocation of resources among the public and the private sector, weighting both economic and socio-environmental aspects. ${ }^{177}$ However, the specific ways through which socio-environmental objectives can be concretely integrated and pursued through PPPs may vary widely according, for instance, to the type of infrastructure or service to be delivered and the political, economic and social environment where the public and private sector have to carry out the project. ${ }^{178}$ The planning, operation and management of a public-private cooperation that promotes sustainable development objectives is, thus, highly challenging. It requires the ability to balance a number of competing objectives: short and long-term value, overall project's costs to be recouped during the contract life and the achievement of innovation, social and environmental targets. All this, in a way that complies with EU and national public procurement rules.

In this respect, the EU legal framework within which PPPs can be awarded and structured offers considerable spaces for the inclusion of socio-environmental considerations in such arrangements. For instance, the new rules on LCC approach allow the parties involved in a PPP to take into full account the life cycle of a service or infrastructure delivered under such scheme. Moreover, the most straightforward answer to the question of where sustainable development objectives can find space in a PPP is that sustainable development goals can easily be integrated when project's proposals are evaluated and scored against award criteria. Price can, in fact, be weighed against sustainable development considerations upon pre-defined models or schemes. Nonetheless, decisions taken also during other phases of the procurement process can affect the

\footnotetext{
${ }^{175}$ C Skelcher, 'Public-Private Partnerships and Hybridity' in E Ferlie, L J Lynn Jr, C Pollitt (eds), The Oxford Handbook of Public management (Oxford University Press, 2005) 347.

${ }^{176}$ See, for instance, S P Mullin, 'Public-Private Partnerships and State and Local Economic Development: Leveraging Private Investment' [2002] Reviews of Economic Development Literature and Practice, available at http://fresnostate.edu/academics/oced/documents/Public-Private\%20Partnerships.pdf.

${ }^{177}$ S Colverson, O Perera, 'Harnessing the Power of Public-Private Partnerships: The role of hybrid financing strategies in sustainable development' [2012] International Institute for Sustainable Development, available at

http://www.iisd.org/pdf/2012/harnessing_ppp.pdf. G Hodge, C Greve, 'Public-Private Partnerships: an International Review' [2007] Public Administration Review, 545, 558.

${ }^{178}$ S H Linder, 'Coming to Terms with the Public-Private Partnerships, A Grammar of Multiple Meanings' [1999] American Behavioral Scientist, 35, 51. E H Klijn, 'Public-Private Partnerships: deciphering meaning, message and phenomenon' in G Hodge, C Greve (eds), International Handbook of PPP (Edgar Elgar, 2010) 68, 80. 
inclusion of socio-environmental concerns in PPP arrangements. The first step to be taken for the structure of private-public cooperation oriented towards the achievement of socio-environmental benefits is the precise identification and classification of the public sector's needs. The decisions taken at this initial stage by the contracting authority on needs' assessment are, in fact, crucial, being capable of affecting the degree of sustainability that will be included in the PPP. ${ }^{179}$ Such decisions may, for instance, concern the extent to which environmental or maintenance concerns are desired during the performance of the contract.

Once all needs, especially in terms of socio-environmental sustainability, are clearly set, contracting authorities should have an idea of the solutions that the private market can offer. The engagement in some form of pre-procurement can be beneficial in this respect and for the structuring of a PPP that allows scope for sustainable development considerations. ${ }^{180}$ Preliminary answers to questions on the overall feasibility of the project can be obtained. The engagement with potential private partners during pre-procurement can also promote competition levels that can contribute to the award of the PPP contract to the best private partner. ${ }^{181}$ In order to secure competition, pre-procurement could be carried out through open days dedicated to economic operators or by distributing questionnaires or project's booklets. In addition, web searchers in online databases or catalogues could be carried out. Pre-procurement can be an important moment for the public sector to understand which could be the best contract's requirements, tender deadlines and payment mechanisms that can better secure sustainable development considerations. ${ }^{182}$ This phase can also encourage the creation of consortia, which normally represent the private side of PPPs, since they are normally more capable of delivering a full range of objectives.

The decisions taken during this phase can influence the degree of sustainability included in a PPP and they are more likely to be taken in the right way if the public sector fully understands the market within which it can cooperate. ${ }^{183}$ From a sustainable development perspective, the advantages of pre-procurement vary according to the ability of the public sector to use the information collected, without giving any economic operator a real or perceived advantage. Thus, the engagement with private operators must maintain a competitive tension.

Further steps, which can allow the integration of socio-environmental considerations in the structure of PPP arrangements, are the definition of the subject-matter and scope of the contract and the choice of the more adequate PPP legal type for the achievement of the set goals. ${ }^{184}$ Contracting authorities must have a clear idea of which could be the best legal scheme, given the specific circumstances of the case at stake and the exact nature of the needs to be satisfied. This is a prerequisite for the choice of the best way through which to structure the competitive tender. The

\footnotetext{
${ }^{179}$ P H Pattberg, Public-Private Partnerships for Sustainable Development: Emergence, Influence and Legitimacy (Edward Elgar, 2012). P D Rwelamila, P Fewings, C Henjewle, 'Addressing the Missing Link in PPP Projects: What Constitutes the Public?' [2014] Journal of Management in Engineering.

${ }^{180}$ On pre-procurement under the 2014 Directives, see Chapter II, para 4.2.4.1., letter a).

${ }^{181}$ A Semple, A Practical Guide to Public Procurement, op. cit., 71.

182 A R Apostol, 'Pre-commercial Procurement in Support of Innovation: Regulatory Effectiveness?' [2012] PPLR.

${ }^{183}$ B Ryan, Public-Private Partnerships and Sustainability, Principles Guiding Legislation and Current Practice, 2004, available at http://arrow.dit.ie/cgi/viewcontent.cgi?article=1007\&context=futuresacrep.

${ }^{184}$ Typologie des PPP: Comparaison Juridique et Terminologique des PPP dans les Conceptions Française et Anglosaxonne, Mission d'appui aux partenariats public-privé (MAPPP), 2013, available at

http://www.economie.gouv.fr/files/files/directions_services/ppp/glossaire_fr_en.pdf. G Hodge, C Greve, 'Theorizing Public-Private Partnership Success: A Market-Based Alternative to Government?' paper for the Public Management Research Conference at Syracuse University, 2-4 June 2011, Themed Panel on 'Market-Based Alternatives to Government', available at http://openarchive.cbs.dk/bitstream/handle/10398/8573/Greve_2011_c.pdf?sequence=1. 
choice of the procedure, in fact, normally reflects the nature of the contract to be awarded and the private market operator with which it will be signed. As seen, the competitive dialogue, the CPN or the innovation partnership appear to be the most suitable procedures for the award of PPP contracts. ${ }^{185}$ The decisive factors that should orient public authorities in the choice of the procedure for the delivery of an investment project under a PPP are the following. The desired level of interaction with potential private partners, which is fundamental for the identification of the best proposal, resources and expertise available to carry out the procedure. ${ }^{186}$ So the choice of the most adequate procedure, depends on the specific features of the project to be delivered and on the ability of the public sector to manage negotiations or dialogues, maintaining a competitive tension among private operators. ${ }^{187}$

Technical specifications also play a crucial role in the award of PPPs that incorporate sustainable development concerns. As seen in the previous paragraphs, specifications have the potential of positively affecting the attainment of sustainability targets. They control which tenders will proceed towards the assessment against award criteria. Thus, the substance of technical specifications determines what will be offered and how it will be delivered. Unclear or unnecessarily complicated specifications can hinder the scope of sustainability into PPP arrangements by reducing the number of proposals submitted or the achievable quality. Technical specifications have to avoid negative effects during the contract management phase, such as outputs that do not satisfy the public sector's needs. ${ }^{188}$ In complex public contracts, such as PPPs, this issue can be covered by the definition in advance of the required results, rather than the specification of how outputs should be achieved, which is instead determined by the private party. Unarguably, some ambiguities in specifications sometimes cannot be avoided or are even intentional, for instance, when the contracting authority wants to test the private sector to see what it can offer and in which conditions. In this case, the public sector may include options in the scope of a tender, identify minimum requirements and indicate how options or variants will be valued. In the competitive dialogue procedure, technical specifications do not have to be defined in advance. Proposals have to meet the contracting authority's requirements description that can be later specified and defined. For complex public contracts, this can reduce costs in the long-run because it guarantees that the solution proposed actually fits with the public sector's needs reducing risks of underperformance. ${ }^{189}$

Furthermore, selection criteria can secure sustainable development considerations within the structure of PPPs. They limit the number of candidates and ensure that those invited to tender have the specific technical, financial and professional capability to carry out the project. If such

\footnotetext{
${ }^{185}$ See above Chapter II, para 4.2.4.1., letters d), e) and f). J Davey, 'Procedures Involving Negotiation in the New Public Procurement Directive: Key Reforms to Grounds of Use and the Procedural Rules' [2014] PPLR, $103,111$.

${ }^{186}$ A Brown, 'The Impact of the New Procurement Directive in Large Public Infrastructure Projects: Competitive Dialogue or Better the Devil you Know' [2004] PPLR, 173. S S Charveron, 'Competitive Dialogue threatens PFI' [2007] Construction Law, 29.

${ }^{187}$ S Arrowsmith, S Treumer, 'Competitive Dialogue in EU Law: A Critical Review' in S Arrowsmith, S Treumer (eds), Competitive Dialogue in EU Procurement (Cambridge University Press, 2012). A Goddard, 'Procedures Involving Negotiation in the New Public Procurement Directive: Key Reforms to the Grounds for Use and the Procedural Rules' [2014] PPLR, 103, 111. M Burnett, 'The New Rules for Competitive Dialogue and Competitive Procedure with Negotiation in Directive 2014/24 - What Might They Mean for PPP?' [2015] EPPPL, 62, 71.

${ }^{188}$ C Skelcher, 'Governing Partnerships' in G A Hodge, C Greve, A E Boardman Van Dusen (eds), Handbook on Public-Private Partnerships (Edward Elgar, 2012).

${ }^{189}$ M Burnett, 'The New European Directive on the Award of Concession Contracts, Promoting Value for Money in PPP Contracts?' [2014] EPPPL, 86, 103.
} 
assessment is not undertaken properly, it may hinder the scope for sustainable development considerations. For instance, private partner's deficiencies that could have been identified at an earlier stage through an in depth investigation may lead to under-performance and limited scope for sustainability. Thus, in order to secure socio-environmental considerations within the structure of PPPs, it is important to set the bar of selection at an adequate level, which means upon the specific requirements of the project.

Moreover, a crucial role is played by award criteria. ${ }^{190}$ They have to be linked to the subject matter of the contract and may refer to qualitative, environmental and/or social aspects. Their weighting and application is also very important. In fact, their weighing has to adequately reflect the importance given to sustainable development objectives. Moreover, contracting authorities may use the LCC approach to calculate costs in a broader way, including operating and end-life costs as well as environmental externalities.

Furthermore, contract terms allow the inclusion of sustainable development considerations in the structure of PPPs in a number of different ways. First of all, they frame the content and purpose of a PPP. Then, they can contain special performance conditions. These have to be linked to the subject-matter of the contract and be indicated in the call for competition or in the procurement documents. The 2014 Directives expressly provide that such conditions can include economic, innovative, environmental, social or employment-related considerations. ${ }^{191}$ Moreover, contract terms can secure sustainability by foreseeing well-drafted, appropriate and proportionate penalties and bonus payments in case the private partner under-performs or achieves better results than those agreed upon. Financial incentives or penalties linked to performance levels are, in fact, an effective way through which to foster sustainable development goals. ${ }^{192}$ Additionally, socio-environmental considerations can be supported through an effective risk allocation - which is specified through contract clauses - between the parties involved. A transfer of excessive or inappropriate risk to one party may represent an obstacle to an effective generation of socio-environmental benefits under PPPs.

The operation or delivery phase per se falls outside procurement as generally defined. ${ }^{193}$ Nonetheless, the way in which PPP contracts are managed is very important to secure sustainable development issues. The private partner must have the actual capacity and willingness to perform what is agreed upon in the contract, while the contracting authority must be able to verify outcomes and identify potential difficulties at an early stage. This requires that an effective contract management should be in place. Without it, the value attained in the previous tender phases may become irrelevant. Therefore, specific contractual clauses must identify the operational responsibilities of the private partner and how its performance can be measured, in order to allow the contracting authority to carry out compliance monitoring. In this respect, the inclusion of key performance indicators can support the public sector. Key indicators may vary according to the specific project that has to be delivered. For instance, they can refer to fuel efficiency, route optimizations, emissions levels, use of certain materials, energy performance or use of renewable

\footnotetext{
${ }^{190}$ A Semple, A Practical Guide to Public Procurement, op. cit., 186.

${ }^{191}$ Article 70, Directive 2014/24/EU. Article 87, Directive 2014/24/EU.

${ }^{192}$ L Butler, 'Innovation in Public Procurement: Towards the 'Innovation Union' in F Lichère, R Caranta, S Treumer, Modernising Public Procurement: the New Directive, op. cit., 369.

${ }^{193}$ R Caranta, 'Mapping the Margins of EU Public Procurement Law: Covered, Mixed, excluded and special contracts' in F Lichère, R Caranta, S Treumer, Modernising Public Procurement, The New Directive, op. cit., 67, 96. R Noguellou, 'Scope and Coverage of the EU Procurement Directives' in M Trybus, R Caranta, G Edelstam (eds), EU Public Contract Law, Public Procurement and Beyond (Bruylant, 2014).
} 
energy sources. Provided that the public and private parties involved in a PPP are willing to invest in applying them, they can secure sustainable development objectives. The specific way through which contractual performance is then assessed varies on a case-by-case basis, being less or more complex depending on the specific characteristics of the considered PPP. ${ }^{194}$

\subsection{Public sector budgeting: overview.}

A complete and in depth analysis of the public sector's financial management is not the intention of this paragraph. The aim of this section is, instead, to provide a brief overview of the public sector's budgeting characteristics capable of having an impact on the inclusion of sustainable development considerations into PPPs. The highlight is specifically put on their potential direction of influence.

During the last decades, public budgets became overall more responsive to local needs. Spending capacity was transferred to sub-national public authorities and flexible management practices were implemented. ${ }^{195}$ Moreover, the focus was put on competition and on incentives for the delivery of cost-effective services or infrastructure. Local public authorities not linked to central objectives progressively became capable of preserving and obtaining efficiency savings. ${ }^{196}$ In fact, a contracting authority that knows that it can benefit from its own procurement savings is more easily motivated to achieve them. ${ }^{197}$ These features of public sector budgeting, along with an improvement of the public sector's organizational culture and internal process mechanisms, have the potential of positively influencing the creation of PPPs that integrate and foster also socio-environmental considerations. Sub-national public authorities are typically inclined to engage in partnerships that support local sustainable development goals. Flexibility, competition and incentives on costeffective outputs are other typical elements that can direct public-private parties towards the delivery of high quality level projects.

Furthermore, performance or delivery based budgets link public funds to measurable results, which can in turn be set in terms of sustainable development goals. Thus, delivery based budgets may well fit with PPP arrangements that allow scope for sustainability. Performance assessment methods may vary significantly and range from purely quantitative indicators to those including quality evaluations or users' satisfaction. In order to support sustainable development goals, performance-based budgets should be based on qualitative evaluation of outcomes, rather than on merely numeric quantity of outputs. ${ }^{198}$ Moreover, multi-year budgets are likely to allow flexibility and longer-term assessment of sustainability, thus, securing sustainable development considerations within PPPs, which are by nature long-term and flexible public contracts. ${ }^{199}$

Public budgets normally account capital costs separately from current expenditure. Such division in accounting can lead to difficulties in the consideration and evaluation of life-cycle costs of a public infrastructure or service. In PPPs, capital costs and operational costs are, instead,

\footnotetext{
${ }^{194}$ Assessment methods are more developed in some sectors - such as the health and education fields - than in others.

${ }^{195}$ T Curristine, Z Lonti, I Joumard, 'Improving Public Sector Efficiency: Challenges and Opportunities' [2007] OECD Journal on Budgeting, 5.

${ }^{196}$ A Semple, A Practical Guide to Public Procurement, op. cit., 162.

${ }^{197}$ Among others see, R Hamson, L Bird, 'Devolved Budgets in the Public Sector: A New Conceptual Framework for Consultancy Evaluation' [2008] Journal of Finance and Management in Public Services, 33.

${ }^{198}$ T Curristine, Z Lonti, I Joumard, 'Improving Public Sector Efficiency: Challenges and Opportunities', op. cit., 4. Unarguably, a part from specific sectors - such as health and education - there is a lack of data on the use and impact of different approaches to performance budgeting.

${ }^{199}$ M Spackman, 'Multi-Year Perspective in Budgeting and Public Investment Planning' [2002] draft paper, session III, OECD Global Forum on Sustainable Development, 5.
} 
typically borne both and entirely - or at least in large part - by the private party. Hence, the issue of separation of public accounting is overtaken and longer-term investments in sustainable projects can be carried out. ${ }^{200}$

Furthermore, discount rate policies have an impact on any procurement choice and on the extent to which innovative and sustainable solutions can be offered. In fact, the higher the discount rate is, the lower the actual value of future cash flows is. On the contrary, a lower discount rate entails less expensive capital and a higher value of future cash flows, which supports investments in larger longer-term projects where sustainability issues can be integrated. ${ }^{201}$ In PPPs, the discount rate is usually set according to the individual project level. ${ }^{202}$ Project-tailored discount rates normally lead to a higher value of future cash flows, allowing the private partner to recoup the overall investments made in innovative and sustainable solutions. Therefore, depending on the discount rate policy applied, PPPs are to a varying degree capable of investing in sustainability.

\subsection{Concluding remarks.}

Overall, including sustainable development considerations within PPP contracts entails a number of conceptual and practical challenges that vary from case to case and from project to project. In addition, the little agreement on the precise boundaries of socio-environmental concerns leads to uncertainties on the ways through which they should be compared with other important objectives such as transparency, fairness and competition. Nonetheless, there is a high motivation to pursue sustainable development goals in PPPs.

The Table below aims at summing up the role that the various procurement phases may play in the inclusion of sustainable development considerations in PPPs. It is a general reference framework that needs to be adapted on a case-by-case basis, tailored to the specific PPP legal type used and project's characteristics.

\section{Phase}

Budgeting and Planning

Market examination

\section{Suggested measures}

The public sector should prefer multi-year, performance or availability budgeting and evaluate long-term sustainable needs with stakeholders and end-users. Life-cycle costs should be also considered.

The public sector should properly advertise its needs and look for detailed input from potential private partners, consult other public authorities for advice and use the collected information to clearly identify the scope and specifications of the contract to be awarded. Any competitive advantage to economic operators should be avoided.

\footnotetext{
${ }^{200}$ Among others, see, J Shaoul, A Stafford, P Stapleton, 'The Cost of Using Private Finance to Build, Finance and Operate Hospitals' [2008] Public Money and Management, 101, 108.

${ }^{201}$ A Richard, 'Overview of Budget Systems and Public Procurement in OECD Countries' in OECD, Environmental Performance of Public Procurement: Issues of Policy Coherence (OECD, 2003), 118.

${ }^{202}$ By the way, the discount rate applied may be particularly important when a public sector comparator is used to decide whether to undertake a project with or without private funding. A public sector comparator is a tool used by the public sector to make decisions by verifying whether a private investment proposal offers value for money in comparison with the most effective form of traditional procurement.
} 
The public sector should choose the level of interaction needed to select the best solution. The contracting authority should also verify the available time and resources and

Choice of Procedure

\author{
Technical \\ Specifications
}

Selection

Evaluation

Contract terms

Contract management preferably opt for the competitive dialogue procedure or the CPN. The competitive dialogue procedure should be used when data from potential private partners are needed in order to draft specifications.

The public sector should lay down clear requirements possibly allowing variants for verification of effectiveness.

The public sector should apply selection criteria according to the specific goals to be achieved, verify tenderers' prior performance and the content of the European Single Procurement Document.

The public sector should set award criteria and weightings, which adequately reflect the qualitative, environmental and/or social needs identified. The contracting authority should apply minimum scores to such criteria and use a life-cycle costing approach whenever there is available supporting data.

Contract terms should allocate risks to the party better capable of managing them. Standards conditions should be avoided as they may hinder the achievement of projecttailored sustainable goals.

The public sector should apply adequate and proportionated performance indicators allowing sufficient time and resources for compliance monitoring.

Table 9

Measures that can support the integration of sustainability in PPPs.

\section{Public-Private Partnerships' socio-environmental benefits.}

Through an effective integration of sustainable development considerations, PPPs have the potential for generating a high level of socio-environmental benefits. These can be intentional or unintentional and vary according to the specific structure of the public-private scheme adopted and the public service and/or infrastructure delivered. ${ }^{203}$ In order to better identify them, they are conceptualized into three macro-categories, namely accelerated delivery benefits, enhanced delivery benefits and wider socio-environmental benefits. ${ }^{204}$

\subsection{Accelerated delivery benefits.}

The first category of socio-environmental benefits refers to those gains arising out of events of accelerated deliveries, thus, all those advantages enjoyed by end-users, society and environment connected to an early availability of the public infrastructure and/or service. It is the case of roads,

\footnotetext{
${ }^{203}$ On sustainability and innovation in public contracts see, among others, E Uyarra, K Flanagan, 'Understanding the Innovation Impacts of Public Procurement' [2010] European Planning Studies, 123. L Hommen, M Rolfstam, 'Public Procurement and Innovation: Towards a Taxonomy' [2009] Journal of Public Procurement, 17. J JR Cibinic, R C Nash, C R Yukins, Formation of Government Contracts (CCH, 2011).

${ }^{204}$ The Non-Financial Benefits of PPPs, A Review of Concepts and Methodology, European PPP Expertise Centre, European Investment Bank, June 2011, available at http://www.eib.org/epec/resources/epec-non-financial-benefits-ofppps-public.pdf.
} 
schools or hospitals, which are delivered earlier than normally expected or planned under traditional procurements. In such cases, broader society can profit sooner from the estimated socioenvironmental benefits arising out the anticipated functioning of public transportations, education or health services. Thus, accelerated delivery benefits vary according to how quickly public services and/or infrastructure are made operational as well as to the inherent characteristics of the project.

PPP arrangements are capable of accelerating the delivery of an infrastructure and/or of a service by guaranteeing quick or on-time construction performances, ${ }^{205}$ thereby providing investment projects that actually start to operate in a short time or at the pre-arranged date.

Traditional public procurement means may as well deliver on-time public infrastructure or services. However, in PPPs there is a higher pressure to complete investment projects on-time. Normally, this pressure comes from banks and/or financial institutions who lend money only if it is agreed that the infrastructure or service will be delivered in a relatively short time so that the private party can start to pay back the loan. Moreover, PPP contracts usually have a well-functioning penalty mechanism, which financially burdens the private party for every day of delay in the completion of works. ${ }^{206}$ Furthermore, PPPs have the ability of guaranteeing quick deliveries because of the higher availability of budgetary funds. These increase the possibilities of using technology and construction methods that are more effective and allow quicker projects deliveries. Thus, on-time construction performances are mainly achieved through high levels of budgetary funds and ad hoc financial incentives set out in the terms and conditions of the PPP contract. ${ }^{207}$ In the latter respect, whenever it is agreed that public payments will occur only when the planned service and/or infrastructure is actually delivered, the private partner is highly motivated to deliver it on-time. Empirical data showed that this happens also if the private sector has to shoulder additional costs for the fulfilment of an on-time delivery contractual obligation. ${ }^{208}$ One of the objectives of financial planning, feasibility studies and due diligence activities is to identify the conditions that can better guarantee an on-time delivery of the planned infrastructure and/or service. PPPs are usually structured in order to easily foresee and handle unexpected developments or events of delay.

\footnotetext{
205 See, for instance, National Audit Office, PFI: Construction Performance, 2003, available at https://www.nao.org.uk/wp-content/uploads/2003/02/0203371.pdf. Performance of PFI Construction, Report of the National Audit Office, 2009, available at https://www.nao.org.uk/wp-content/uploads/2009/10/2009_performance_pfi_construction.pdf. Standard and Poor's, Infrastructure finance, The Anatomy of Construction Risk: Lessons from a Millennium of PPP Experience, 2007, available at http://www.robbain.com/The\%20Anatomy\%20Of\%20Construction\%20Risk.pdf. A Kappeler, M Nemoz, Economic and Financial Report, Public-Private Partnerships in Europe before and during the recent financial crisis, European Investment Bank, 2010, available at http://www.eib.org/epec/resources/efr_epec_ppp_report1.pdf. University of Melbourne, National PPP Forum, Benchmarking Study, Phase II, Report on the Performance of PPP projects in Australia when compared with a representative sample of traditionally procured infrastructure projects, 2008, available at http://infrastructureaustralia.gov.au/policy-publications/publications/files/PC_Submission_Attachment_K.pdf.

${ }^{206}$ See, for instance, the United Kingdom Treasury - Standardisation of PF2 Contracts, 8.6 Bonus Payments for Early Service Commencement, 63, available at

https://www.gov.uk/government/uploads/system/uploads/attachment_data/file/207383/infrastructure_standardisation_of contracts_051212.PDF.

${ }^{207}$ See National Audit Office, Department of Health, Innovation in the NHS: Local Improvement Finance Trusts, 2005, available at https://www.nao.org.uk/wp-content/uploads/2005/05/050628.pdf.

${ }^{208}$ Op. cit., footnote 159.
} 
Still lingering is, however, the issue of identifying the best way through which to include ${ }^{209}$ accelerated delivery benefits in the ex-ante cost minimisation analysis that public authorities undertake to decide whether to deliver an investment through a PPP or a traditional procurement. The private partner should detail how the PPP project can offer an early availability of the planned infrastructure, identifying and - where possible - measuring the socio-environmental benefits that could be generated. In this respect, the French MAPPP $^{210}$ studied how to assess the value of accelerated delivery benefits. Thanks to numerical assumptions, diagrams and calculations comparing private and public deliveries, the findings hold that the value of the additional benefits arising out PPPs was larger than the additional costs. Hence, the PPP option was justifiable on efficiency grounds. $^{211}$

\subsection{Enhanced delivery benefits.}

The second category of socio-environmental benefits covers all those advantages, enjoyed by endusers, related to enhanced deliveries of public services and/or infrastructure. ${ }^{212}$ Enhanced deliveries occur when a certain project is delivered with an added value in terms of sustainability. Thus, enhanced delivery benefits arise out of a high quality level of a given public service or infrastructure. ${ }^{213}$ They can be generated mainly in three ways. Firstly, when PPPs apply LCC methodologies. ${ }^{214}$ In this case, PPP contractual obligations for infrastructure and/or service maintenance can guarantee duration overtime, providing long-lasting high quality conditions and outstanding benefits. Secondly, when contractual arrangements are set out in a way that allow the application of specific and project-tailored performance standards, better planned and high quality deliveries are assured. ${ }^{215}$ Lastly, provided that a clearly defined PPP governance structure is in place, enhanced delivery benefits are generated, for instance, by due diligence activities carried out by lenders and/or investors, by a well-functioning infrastructure or service management and by the public sector focusing on its core monitoring task.

Moreover, whenever the public partner identifies only the desired output, the generation of enhanced delivery benefits increases. In fact, if the private sector is free to choose the best way

\footnotetext{
${ }^{209}$ For an overview of the followed approaches and evaluation methods see, among others the European Commission, 'Guide to Cost-Benefit Analysis of Infrastructure Projects, Structural Funds, Cohesion Fund and Instrument for PreAccession', Directorate General Regional Policy, 2008, available at http://ec.europa.eu/regional_policy/sources/docgener/guides/cost/guide2008_en.pdf. Extensive data on socio-economics benefits can be, for instance, found at HEATCO, Developing Harmonized European Approaches for Transport Costing and Project Assessment, Proposal for Harmonized Guidelines, 2006, available at

http://heatco.ier.uni-stuttgart.de/HEATCO_D5.pdf.

${ }^{210}$ Mission d'appui à la réalisation des contrats de partenariat, available at http://www.tresor.economie.gouv.fr/missiondappui-aux-partenariats-public-prive.

${ }^{211}$ The Non-Financial Benefits of PPPs, A Review of Concepts and Methodology, European PPP Expertise Centre, European Investment Bank, op. cit..

${ }^{212}$ The number of users may increase if the quality of the infrastructure improves. This is because better services raise the infrastructure or service demand, consequently there are more users that profit of the enhanced delivery.

${ }^{213}$ Op. cit, footnote 159. '4Ps Review of Operational PFI and PPP projects, Local Government's project delivery specialist, 2005, available at https://www.bipsolutions.com/docstore/pdf/11980.pdf. On the quality of services see also, KPMG in collaboration with University College London, Operating Healthcare Infrastructure: Analysing the Evidence, 2010, available at http://www.kpmg.com/TW/zh/IssuesAndInsights/Documents/IGH/Global-infrastructure-spotlight-Benchmarkinghealthcare.pdf.

${ }^{214}$ On LCC applications see, for instance, S Fuller, National Institute of Standards and Technology, Life Cycle Cost Analysis for Sustainable Buildings, available at https://www.wbdg.org/resources/lcca.php.

${ }^{215}$ Op. cit., footnote, 164.
} 
through which to deliver the service and/or build the infrastructure, innovation and socioenvironmental benefits are promoted. ${ }^{216}$ PPPs are typically designed to provide innovative solutions by applying the best available technology, infrastructure designs or service delivery methods. ${ }^{217}$ Thus, by stimulating innovative solutions in the delivery of public services and/or infrastructure, enhanced delivery benefits are generated. For instance, a well-designed and functioning school can support the educational achievement of students. A well-structured hospital can help patients in their recovery. ${ }^{218}$ Since PPPs are long-term contracts, the private partner has strong incentives to invest in solutions that account for the entire life-time of the infrastructure or service, recouping the investments made in the long run.

Investing in innovative and sustainable solutions indeed implies a certain degree of risk. Such risk is generally avoided if there are no advantages or incentives to do so. In traditional procurement, the public sector usually picks from the solutions that worked in the past and adapts them to new circumstances in order to bear fewer risks. Instead, in PPPs, the innovation challenge is crucial. Innovation and sustainability are powerful competitive incentives for the private sector. In order to obtain the award of a PPP contract, private actors are normally strongly encouraged to develop new and innovative delivery methods, leading the way to the generation of enhanced delivery benefits. ${ }^{219}$

\subsection{Wider socio-environmental benefits.}

The third category of socio-environmental benefits refers to all those advantages arising out of a specific PPP investment project and enjoyed by wider society, local community, environment and economy. These may range from job creation to improvement of social cohesion, from better connectivity between cities to the creation of green areas. Further examples of wider socioenvironmental benefits can be innovative solutions or learning environments from which to draw inspiration and exploit best practices, innovative management techniques applied by the private sector capable of being exploited for other public service or infrastructure deliveries, the reliance of consumers on long-term fixed prices and specifically set out outputs. The precise identification of such benefits cannot, however, be provided a priori as it varies from project to project and from PPP to PPP.

\subsection{The open issue of measurement of socio-environmental benefits.}

Socio-environmental benefits can present themselves in various ways and can be largely yielded by PPPs that integrate sustainable development considerations in their structure in an effective way.

\footnotetext{
${ }^{216}$ Cambridge Economic Policy Associates Ltd, Report on Public-Private Partnerships in Scotland, Evaluation of Performance, 2005, available at http://www.gov.scot/Resource/Doc/917/0011854.pdf. CBI, Building on Success: the Way forward for PFI, 2007, available at

http://infrastructureaustralia.gov.au/policy-

publications/publications/files/Bldg_on_success_The_way_forward_4_PFI_UK_CBI.pdf.

${ }^{217}$ E R Yescombe, Public-Private Partnerships: Principles of Policy and Finance, op. cit..

${ }^{218}$ The Non-Financial Benefits of PPPs, A Review of Concepts and Methodology, European PPP Expertise Centre, European Investment Bank, op. cit., 3.

${ }^{219}$ In this respect, two studies carried by KPMG showed that PPP projects can enhance the delivery in the education and health sectors. KPMG, Infrastructure Spotlight Report, PFI in school building - does it influence educational outcomes?, 2009, available at http://www.kpmg.eu/docs/20100120_PFI-in-school-building.pdf.KPMG in collaboration with University College London, Operating Healthcare Infrastructure: Analysing the Evidence, op. cit. . 
However, difficulties related to their measurement still hamper their full consideration. In fact, there is no consensus on how they can be best calculated. Emblematic, in this respect, is the following quote attributed to Albert Einstein.

\section{'Not everything that can be counted counts and not everything that counts can be counted.'}

The question of measurement of socio-environmental benefits is an open issue. It is a subject of debate and empirical studies entailing practical and conceptual complex challenges. However, it is an issue that must be dealt with in order to truly allow a full integration of sustainable development considerations into the structure of any public contract and, especially, of PPPs. ${ }^{220}$ In the field of public-private collaborations, evaluation methods of socio-environmental benefits are still modest and data on applications of life-cycle costing methodologies are rare. ${ }^{221}$ This leads to a high risk of misrepresentations of PPPs' costs and benefits, which in turn should be avoided if PPP projects are to be promoted for an economic and socio-environmental sustainable development within the EU. ${ }^{222}$ Well-structured forecasting methods of socio-environmental benefits identification and support of empirical evidence could, instead, decrease mistakes and bias in the choice and structuring of PPP projects. Assessments should be carried out by referring to classes of similar PPPs and measurement of socio-environmental benefits should entail engagement with stakeholders and end-users. Furthermore, details on the benefits achievable through a certain PPP project should be provided in advance by the private sector. This is because once identified and measured, socioenvironmental benefits should be considered alongside with economic benefits providing contracting authorities with a comprehensive knowledge that can allow them to make coherent decisions for a sustainable delivery of public services and/or infrastructure.

Ongoing studies and researches keep on putting efforts into finding ways through which measure socio-environmental benefits when market prices are not available. ${ }^{223}$ Some approaches refer to consumers' perceptions or willingness to purchase certain goods and/or pay for the provision of a service, for instance, by relying on interviews and questioners. ${ }^{224}$ A complex task remains, however, the recognition of a monetary value for users' satisfaction. In this respect, scales comparing satisfaction levels may be used. They should, however, be applied over various investment projects within a specific sector and be supported by empirical evidence and a certain degree of consensus. ${ }^{225}$

\footnotetext{
220 See, among others, the European Investment Bank Evaluation Report, Operations Evaluation Department, Evaluation of PPP projects financed by the EIB - Synthesis Report March, 2005, available at

http://www.eib.org/attachments/ev/ev_ppp_en.pdf. HM Treasury, Value for Money Assessment Guidance, 2008, available at

http://webarchive.nationalarchives.gov.uk/20130129110402/http://www.hm-

treasury.gov.uk/d/vfm_assessmentguidance061006opt.pdf.

${ }^{221}$ See, for instance, E Hochschorner, M Noring, 'Practitioners' use of life-cycle costing with environmental costs--a Swedish study' [2011] International Journal of Life Cycle Assessment.

${ }^{222}$ B Flyvbjerg, 'Policy and planning for large-infrastructure projects: problems causes, cures' [2007] Environment and Planning B: Planning and Design, 578, 597.

${ }^{223}$ See, for instance HM Treasury, The Green Book, Appraisal and Evaluation in Central Government, 2003, available at https://www.gov.uk/government/uploads/system/uploads/attachment_data/file/220541/green_book_complete.pdf.

${ }^{224}$ See, The Non-Financial Benefits of PPPs, A Review of Concepts and Methodology, European PPP Expertise Centre, European Investment Bank, op. cit..

${ }^{225}$ In this regard, see, for instance, the Department of Treasury and Finance, Investment Evaluation: Policy and Guidelines, 1996, State of Victoria, Australia.
} 
In principle, environmental benefits are generally measurable, while social ones are considered by nature more difficult to measure. The main difficulty is to isolate their causal effect. Thus, to ascribe them to the PPP and not to other sources. Hence, from an econometric point of view, the situation produced with a PPP should be compared against a counterfactual, which is a hypothetical identical situation without the PPP. Typically, socio-environmental benefits are being measured by referring to cost reductions, minimized risks and revenue growth. ${ }^{226}$

Management tools allow the measurement of cost reductions achieved through the inclusion of sustainable development considerations. ${ }^{227}$ Therefore, socio-environmental benefits, such as an improved education, workplace safety, social inclusion, $\mathrm{CO}_{2}$ emissions, water and solid waste, are measured by looking at the savings obtained. ${ }^{228}$ Moreover, the management of the different risks arising out of socio-environmental factors represents another measurement technique. The improvement of the quality of technical management of water, energy, waste or greenhouse gas emissions reduces the risk of fines and environmental risks. The improvement of working conditions does not only reduce the risk of ILO conventions violations, but also has a beneficial effect on costs and quality. In this respect, analyses on externalities allow private operators to map, compare, rate and identify the most significant sustainability risk. When the most relevant riskcause is identified, possible mitigation measures are assessed and benchmarked against one another. An alternative process is identified and a monetary value is given to the socio-environmental externality. ${ }^{229}$ Finally, socio-environmental benefits are measured by evaluating the increased growth revenue obtained through the inclusion of sustainable development considerations. Studies have shown that consumers are willing to pay high premiums for sustainable products. ${ }^{230}$ An increasing number of consumers is, in fact, looking for sustainable products. ${ }^{231}$

Under the 2014 Directives, in order to consider environmental benefits contracting authorities have to indicate which will be the method used to monetize them. Such a method has to (i) be based on accessible, verifiable, objective and non-discriminatory criteria and (ii) use readily available data to any diligent tenderer. ${ }^{232}$ If there is a common methodology at EU level for LCC calculations in a certain sector, it has to be used. Reference is explicitly made to the Clean Vehicles Directive. ${ }^{233}$ Usually, LCC calculations methods are based on purely financial assessments that consider four main factors: investment, operation, maintenance and end of life-disposal costs. The effectiveness of the LCC approach depends on the extent of its scope and on the methodology used. At times, the latter may be incomplete ${ }^{234}$ or based only on expert's evaluations, not on hard evidence. ${ }^{235}$

\footnotetext{
${ }^{226}$ O Bruel, O Menuet, P F Thaler, R Kromoser, Time to Measure Value Creation!, Whitepaper, HEC, EcoVadis, Sustainable Procurement Barometer, 2013, available at https://www.atkearney.de/documents/856314/4303900/HEC_AT+Kearney_EcoVadis_Sustainable+Procurement+Baro meter+2013.pdf/8b1e9a61-52e3-4f1f-8e77-e0f3c21757e9.

${ }^{227}$ O Bruel, O Menuet, P F Thaler, R Kromoser, Time to Measure Value Creation!, ibid., 26.

${ }^{228}$ Ibid., 28.

${ }^{229}$ O Bruel, O Menuet, P F Thaler, R Kromoser, Time to Measure Value Creation!, ibid., 31.

${ }^{230}$ The Sustainability Imperative, New insights on Consumer Expectations, Nielsen, 2015, available at http://www.nielsen.com/content/dam/nielsenglobal/dk/docs/global-sustainability-report-oct-2015.pdf.

${ }^{231}$ D Hunkeler, K Lichtenvort, G Rebitzer, Environmental Life Cycle Costing (CRC Press, 2008).

${ }^{232}$ Article 68, para 2, Directive 2014/24/EU. Article 83, para 2, Directive 2014/25/EU.

${ }^{233}$ Directive 2009/33/EC of the European Parliament and of the Council of 23 April 2009 on the promotion of clean and energy-efficient road transport vehicles.

${ }^{234}$ E Hochschorner, M Noring, 'Practitioners' Use of Life Cycle Costing with Environmental Costs - a Swedish Study', op. cit, $897,902$.

${ }^{235}$ E Korpi, T Ala-Risku, 'Life Cycle Costing: A Review of Published Case Studies' [2008] Managerial Auditing Journal, 240, 261. 
Calculation methodologies are, in fact, usually tailored to the specific circumstances of the case at stake $^{236}$ and their outcomes vary according to the reliability of the data used, the discount rate applied and the life-cycle phases considered.

An adequate methodology supporting sustainable public procurement is the Environmental Life Cycle Costing (hereinafter ELCC), which takes into account the environmental impact of products, works or services provided through a Life Cycle Assessment (hereinafter LCA) analysis. $^{237}$ LCA assesses the impacts of a product on the environment during its lifetime. Environmental costs are evaluated, for instance, with regard to acidification, eutrophication, land use or other measurable effects. ${ }^{238}$ The UK and the Netherlands have been carrying out LCC analyses for the procurement of, especially, energy-efficiency and refurbishment of existing buildings (e.g. heat, light, ventilation and management systems), in some cases of indoor and outdoor lighting, solar systems, office equipment, such as computers, and printer copy machines. Italy is, instead, experiencing the use of LCC methodologies especially in the procurement of energy-efficient buildings. ${ }^{239}$

As mentioned, social benefits, such as social cohesion, are more challenging to forecast and measure with any degree of certainty. ${ }^{240}$ Nevertheless, attempts in this direction have been made. ${ }^{241}$ For instance, work has been done to elaborate a common methodology to measure social returns on investment $^{242}$ and social life-cycle assessment ${ }^{243}$ of certain products and services. In this respect, Recital 96, Directive, 24/2014/EU, calls for an investigation at EU level of the feasibility of a common methodology for social life-cycle costing using as starting point the Guidelines developed by the United Nations Environment Program. ${ }^{244}$ Moreover, public authorities around Europe are experiencing new methods of inclusion of social value in public procurement especially through contract management techniques, such as inspections and verification of private sector's compliance with a specifically agreed upon code of conduct. ${ }^{245}$ These contract management techniques may be

\footnotetext{
${ }^{236}$ Ibid.

${ }^{237}$ D Hunkeler, K Lichtenvort, G Rebitzer, Environmental Life Cycle Costing, op. cit..

${ }^{238}$ For instance, see the evaluation tool for $\mathrm{LCC}$ and $\mathrm{CO}_{2}$ emissions developed by the SMART - SPP project. Guidance on the use of the tool is available at http://www.smartspp.eu/fileadmin/template/projects/smart_spp/files/Guidance/Final_versions/EN_SMART_SPP_Tool_User_Guide_201 1_FINAL.pdf

${ }^{239}$ O Perera, B Morton, T Perfrement, Life Cycle Costing in Sustainable Public Procurement: a Question of Value, International Institute for Sustainable Development, Winnipeg, 2009, available at https://www.iisd.org/pdf/2009/life_cycle_costing.pdf.

${ }^{240}$ C Jobse, N Dimitri, LCC-Calculations and the Principles of Public Procurement, available at https://underpinn.portals.mbs.ac.uk/Portals/70/docs/2.1\%20-\%20Jobse\%20\&\%20Dimitri\%20-

$\% 20 \mathrm{LCC} \% 20$ calculations\%20v1\%200.pdf.

${ }^{241}$ D Hunkeler, 'Societal LCA Methodology and a Case Study' [2006] International Journal of Life Cycle Assessment, 371, 382. A Bala, M Raugei, G Benveniste, C Gazulla et all, 'Simplified Tools for Global Warming Potential Evaluation: When 'Good Enough' Is Best' [2010] International Journal of Life Cycle Assessment, 489, 498.

${ }^{242}$ Details on the methodology can be found at http://impactinvesting.marsdd.com/simt/social-return-on-investmentsroi/.

${ }^{243}$ The Guidelines for social life cycle assessment of products is available at http://www.unep.org/pdf/DTIE_PDFS/DTIx1164xPA-guidelines_sLCA.pdf.

${ }^{244}$ Ibid.

${ }^{245}$ Good Practice in Socially Responsible Public Procurement, Approaches to Verification from Across Europe, The Landmark Project, Moving Towards Socially Responsible Procurement, 2012, available at http://www.landmark-project.eu/fileadmin/files/en/latest-achievements/LANDMARK-good_practices_FINAL.pdf. 
relevant also for the measurement of social benefits. ${ }^{246}$ For instance, by looking at the extent to which codes of conduct are complied with, the social value achieved may be measured. Codes of conduct, in fact, normally refer to core ILO conventions and work related health and safety legislation, labour law rules on minimum wages and social insurance. Codes of conduct are used as a list of commitments that economic operators have to agree upon in order not to be excluded from tender procedures. Contracting authorities also use labels, verifications schemes and follow-up questionnaires - as part of their contract management process - which are usually followed by inspections. $^{247}$ Thus, even though the verification and monitoring aspect is complex because of a lack of an effective auditing process, the public sector has found ways to embark in the path of social benefits' measurement.

\section{Conclusions to this Chapter.}

In $2009^{248}$ the EU Commission - with the purpose of promoting PPPs - published a Communication 'Developing Public Private Partnerships' stressing their importance specifically in connection with climate change fighting, renewable forms of energy and sustainable transport promotion. Outlining new paths of concern for potential EU intervention, this document of the Commission defined PPPs as

\section{[...] interesting vehicles for the long-term structural development of infrastructure and services, bringing together distinct advantages of the private sector and the public sector, respectively. ${ }^{249}$}

Moreover, the Agenda 'Transforming Our World: the 2030 Agenda for Sustainable Development ${ }^{250}$ set 17 new Sustainable Development Goals and 169 targets. It called for action in five areas critically important: people, planet, prosperity, peace and partnership. UN member States were asked to develop, accordingly, indicators for the implementation of the Sustainable Developments Agenda. The majority of participants agreed upon the need for an implementation of measures based on an innovative partnership between governments, businesses and civil society within the framework of PPPs. ${ }^{251}$ PPPs were specifically recognized as important tools for the achievement of the Sustainable Development Goals. ${ }^{252}$ The main reasons lying behind such recognition are the following:

\footnotetext{
${ }^{246}$ Good Practice in Socially Responsible Public Procurement, Approaches to Verification from Across Europe, The Landmark Project, ibid., 12.

${ }^{247}$ Good Practice in Socially Responsible Public Procurement, Approaches to Verification from Across Europe, The Landmark Project, ibid., 8.

${ }^{248}$ See the Communication from the Commission to the European Parliament, the Council, the European Economic and Social Committee and the Committee of the Regions, 'Mobilizing private and public investment for recovery and longterm structural change: developing Public Private Partnerships', Brussels, 19.11.2009, COM (2009) 615 final, 10.

${ }^{249}$ Ibid.

${ }^{250}$ The Agenda was greed by the 193 United Nations members at the Sustainable Development Summit held at the UN Headquarters in New York on September 2015.

${ }^{251}$ See, Goal 17 of the Sustainable Development Goals.

${ }^{252}$ I Zapatrina, 'Sustainable Development Goals for Developing Economies and Public-private Partnership' [2016] EPPPL, 39. 
1. The need to mobilize the private sector and institutional capital investors to achieve sustainable development goals through modern, environmental friendly, energy efficient and smart infrastructure. PPPs are, in fact, the spotlight of International institutions, such as multilateral development banks, donor countries, private commercial lenders and institutional investors. In this respect, these entities have recently created the Global Infrastructure Facility, which is a global, open platform supporting the planning and structuring of PPPs in order to mobilize the private sector and institutional investor capital. ${ }^{253}$

2. The need to ensure a global partnership between governments, private businesses and society. In this respect, PPPs are arrangements focusing on results, risk sharing and cooperation between public and private actors.

3. PPPs are perceived as effective tools for the provision of socially inclusive development, which is one of the key elements of sustainable development growth. ${ }^{254}$ Without partnerships, and so without understanding and trust between public authorities, economic operators and society, it is difficult to realize shared public investment projects. In addition, PPPs are believed to create incentives for job creation, entrepreneurship, innovation development, scientific and technological capacity improvement.

In complex contractual formats - such as PPPs - sustainability and innovation are distinctive features. They characterise the private market by feeding competition among economic operators through costs reduction and quality improvement. ${ }^{255}$ They allow consumers to enjoy enhanced products, infrastructure or services. In public markets, innovation and sustainability are, instead, usually not a priority. The demand is institutionalised and it normally functions according to budgetary considerations, rather than on price mechanisms. Public markets are based on the achievement of specific tasks, above all, the pursuit of the public interest. Thus, products, infrastructure, services are seldom innovative, sustainable or technologically advanced and the price is mostly defined in tenders. ${ }^{256}$ In principle, innovation does not fit well within the legal fundamentals of the procurement regime, being also expensive in terms of capital and resources needing many years to recoup the investments made. The desirability for sustainability and innovation in public contracts is hindered by the difficulties of their regulation. They are, in fact, aspirational and intangible elements, which do not typically adapt with the procedural uniformity of awarding procedures.

It is within this picture that this Chapter aimed at investigating the relationship between PPPs and sustainable development, or better, the way in which public-private cooperation schemes can integrate and promote sustainable development objectives. In order to do so, this Chapter, first of all, examined the meaning and boundaries of the concept of sustainable development. Then, it discussed the ability of public procurement as an effective implementing measure of sustainable development goals. Then, it delved into the extent to which EU law allows scope for sustainability into public procurement. Specifically, attention was put on the 2014 Directives. Furthermore, it discussed how sustainable development considerations can be included into the choice, award and

\footnotetext{
253 World Bank, Global Infrastructure Facility, available at http://www.worldbank.org/en/programs/globalInfrastructure-facility.

${ }^{254}$ I Zapatrin, 'Sustainable Development Goals for Developing Economies and Public-private Partnership', op. cit., 40.

${ }^{255}$ C H Bovis, Editorial, [2015] EPPPL, 59, 61.

${ }^{256} \mathrm{C}$ Edquist, L Hommen, L Tsipouri, Public Technology Procurement and Innovation (Kluwer Academic Publishers, 2000).
} 
structure of PPPs. Finally, this Chapter analysed the possible socio-environmental benefits achievable, with an overview on the open issue of their measurement.

Overall, it emerged that through PPPs innovation and sustainable development goals have the possibility to be effectively promoted. In public-private cooperative models, the private partner's motivation, in fact, creates a favourable environment for innovation and sustainability. PPPs can balance price, cost, risk, quality and performance with ongoing improvements, which in turn support the achievement of sustainable development objectives. PPP models and mechanisms can be adapted to the demands of sustainable development. Their choice, planning, structure and management can be designed in a sustainably oriented way. Financial feasibility studies can be adjusted to incorporate the assessment of socio-environmental benefits in the light of sustainable development objectives. However, capacity building measures and supporting institutions have to be functioning and in place. Moreover, the overall ability of PPPs to integrate and promote sustainable considerations largely depends on the efficiency and innovation capacity of the private partner. Thus, an incentive-based regulation is fundamental. Therefore, at EU level, a system that improves outputs, defines prices in a sustainable manner, sets boundaries to monopoly profits, increases incentives for the private sector to be more efficient and innovative, while reducing costs, should be promoted. 


\section{CHAPTER - MEMBER STATES' EXPERIENCE: THE UNITED KINGDOM, THE NETHERLANDS AND ITALY}

\section{Introduction.}

This Chapter will examine if the previous theoretical and academic discourse can be validated on practical grounds. Therefore, if in the every-day practice PPPs are actually capable of promoting sustainable development considerations through the generation of socio-environmental benefits.

The research questions that will be addressed through this Chapter will be. which are the spaces for sustainable development considerations that can be located within PPP schemes according to national policies and public procurement regimes of the Members States studied? Through which practical means (i.e. tender and contractual strategies) public and private actors can actually integrate sustainability concerns within PPPs' structures and, therefore, deliver also socioenvironmental benefits?

Therefore, it will be first of all explored the room for sustainable development concerns into the public contracts and concession law regimes of the Member States studied. It will be, hence, provided an overview of the policy and legal framework allowing space for sustainability considerations into public contracts within each jurisdiction. All three Member States enacted domestic laws that closely follow the content of the EU 2014 Directives. The UK did so through two different Acts, which came into force on February 2015 and April 2016, ${ }^{1}$ while the NL amended on July 2016, the 2012 Dutch Procurement Act, the Aanbestedingswet. ${ }^{2}$ On April 2016, Italy took advantage of the Directives' transposition period to enact a full and comprehensive reform that revised and updated the existing public contracts and concession law. ${ }^{3}$

A general theoretical reconstruction of the stated national rules, transposing the EU 2014 Directives, will be provided, however, highlighting only those provisions (and policies) that allow room for sustainable development considerations in public contracts, and so into PPPs.

Secondly, an empirical and field research will follow in order to explore the concrete strategies through which public and private actors may implement socio-environmental considerations within PPPs ${ }^{2}$ structures and, thus, foster sustainable development throughout the EU. To this end, for each Member State studied, three representative case studies will be presented. These were chosen according to the following criteria:

i. operational PPPs carried out in the UK, the NL and Italy.

The generation of socio-environmental benefits through PPPs can be investigated only if the considered PPP projects are in the operation and maintenance phase.

\footnotetext{
${ }^{1}$ See below, paragraph 2.1 .

${ }^{2}$ See below, paragraph 3.1 .

${ }^{3}$ See below, paragraph 4.1 . 


\section{CHAPTER - GENERAL CONCLUSIONS TO THIS STUDY}

\section{Overview of the Research carried out.}

This thesis discussed the ability of PPPs to generate socio-environmental benefits, thus, their capability to promote sustainable development throughout the EU. It acknowledged PPPs as an effective public delivery means of both economic and sustainable gains. In other words, it recognised public-private arrangements as key elements, not only for the functioning of the Internal Market, but also for the generation of socio-environmental benefits, such as social justice issues and shared environmental policy purposes.

Chapter I preliminarily clarified the aim of the study and the research questions as well as the definitions used and the literature reviewed. Moreover, it explained the structure and the methodology adopted as well as the research's limitations and exclusions. Before delving into the study of the actual scope for sustainability considerations within public contracts and concessions, according to the EU public procurement regime and relevant national rules of the Member States considered, Chapter II provided an understanding of the PPP phenomenon as a whole. The concept of PPPs was investigated at both the International and EU level. It was highlighted that at both levels there is no unique or widely accepted definition of PPPs and that their actual implementation displays a heterogeneous and complex universe where a vast variety of definitions, categories and models fall within the PPP notion. The term PPP, in fact, broadly describes different types of contractual arrangements. It is understood in different ways according to the country context, the sector, the different legal, regulatory and investment considerations involved, the specific market structure, industry, organization and project-related features. The definition of PPPs used by the OECD states that PPPs are 'long-term agreements between the government and a private partner whereby the private partner delivers and funds public services using a capital asset, sharing the associated risks. PPPs may deliver public services both with regards to infrastructure assets (such as bridges, roads) and social assets (such as hospitals, utilities, prisons).'

PPPs come in a wide variety of models and legal types ranging, for instance, from concession contracts to joint ventures. The different levels of formalization have the overall objective of creating a partnership between public and private actors in order to deliver infrastructure and/or services to the public. The degree of involvement of the private partner depends on the specific features of the project and on the output specifications set out by the contracting authority. Moreover, PPPs imply various ideological and managerial choices that are firmly connected to the relationship established between the private and public actors involved. To sum up, they are complex transactions leading to long duration, high-value contracts in high profile sectors where normally an adequate length of time is needed to ensure the private party's investment and profit recovery. In addition, these typical long-term commitments usually represent for the public sector an incentive to choose and invest in more rational and long-term projects and, for the private partner, another reason to plan and deliver more coherent and effective public investment projects.

\footnotetext{
1 'OECD Principles for Public Governance of Public-Private Partnerships' available at http://www.oecd.org/governance/oecdprinciplesforpublicgovernanceofpublic-privatepartnerships.htm. 245
} 
After acknowledging that both at an International and EU level there is no real agreement on a single definition of PPPs, Chapter II showed that there is a wider consensus on PPPs' features and goals. It explained that PPPs are perceived as legal tools capable of delivering public infrastructure and/or services through an enhanced partnership between the public and the private sectors. PPPs, in fact, aim at obtaining an efficient project's risk management and a clear prior identification of its critical success factors, along with an adequate financial analysis according to the specific public asset and/or service that has to be delivered. One of the central goals of PPPs is to save resources and to use those available in an efficient manner. This is done in different ways. For instance, the public sector concentrates on its best skills without using its resources for the realization of projects where it has no expertise. In addition, and thanks to an effective involvement of the private sector in every project's phase, a final product with an improved overall quality can be delivered. A smart use of private sector's skills, expertise, funding, technology and innovation actually supports the achievement of high quality standards. Moreover, PPPs' risk sharing mechanisms functioning at different projects' stages normally entail fewer risks of costs overruns and projects' delays. The vital role of the private sector in the funding and provision of integrated public infrastructure or services requires a continuous coordination between the private and public actors.

Chapter II also provided an understanding of PPPs' legal background by focusing first on the International level and then on the EU level. It was acknowledged that at both levels there is no uniform or ad hoc set of regulation specifically dedicated to PPPs. At a supra-national level, the PPPs' legal background mainly consists of best practices, hence, guidelines, techniques, methodologies, ethics or ideas that, through experience and research, have proven to be the most efficient or prudent course of action. ${ }^{2}$ At the EU level, PPPs are governed by the Treaty principles and by the relevant public contracts and concessions law regime. Treaty principles are general principles that integrate the regulation of each legal category falling within the notion of PPP. They are the first and main regulating legal framework of the PPP phenomenon. Even if general in nature, Treaty principles govern PPPs by adapting themselves to their distinctive features. They are fundamental values and criteria that characterize and integrate a uniform PPP regulation that is still missing. Along the same lines, EU public contracts and concessions law does not provide for a specific regulation of PPPs. Nonetheless, PPP arrangements do fall within the scope of the EU public procurement Directives as they represent a particular category of public contracts. Therefore, Chapter II provided a detailed overview of the reformed public contracts' award procedures and highlighted their relevance and suitability for PPP contracts' awards. Moreover, given that concession contracts are one of the main legal types through which PPPs take form, the key reasons that led to the enactment of the 2014 Concession Directive and its essential characteristics were identified. An understanding of the concept of 'operating risk' was also provided as it is highly relevant in the framework of concessions and, thus, for PPPs. Finally, Chapter II provided an analysis of the PPP phenomenon as implemented in the studied Member States, namely the UK, the NL and Italy.

\footnotetext{
2 See, for instance, the PPPIRC, World Bank guidelines available at http://ppp.worldbank.org/public-privatepartnership/overview/practical-tools/procurement-bidding/standardized-guidelines. The PPPIRC provides sample PPP agreements and concessions, checklists and sample clauses, terms of reference, risk matrices, standard bidding documents developed by government agencies and sample PPP and sector legislation and regulation. These were designed for government officials, project managers and lawyers involved in PPP projects in developing countries. They provide for international experience and precedents to help the development of well-functioning PPPs. 246
} 
As PPPs were studied from the specific perspective of sustainable development promotion, Chapter III delved into the concept of sustainable development, which is a broad and abstract term that brings together various meanings that are often understood differently among individuals, professionals, interest groups, State agencies, political leaders and NGOs. The definition of sustainable development whereby social, economic and environmental considerations are integrated with one another as inseparable and interdependent components of human progress was endorsed.

Next, the relationship between sustainable development and public procurement was analysed. The latter, in fact, is an effective tool through which sustainable development goals can be actually achieved. It is an effective and concrete policy measure through which governments can pursue socially and environmentally responsible practises through the use of public contracts. It is noteworthy that sustainable public procurement, as a specific form of development is growing in terms of both endorsement and implementation.

Chapter III further showed the spaces that EU law recognises to social and environmental aspects, or better, to sustainability objectives, understood as impacts on longer-term human and environmental welfare, within public contracts and concessions. To this end, an overview of the Treaty principles, secondary legislation, soft law and CJEU case law that allow scope for sustainability objectives into public purchasing was presented. Moreover, how sustainable development considerations can be actually integrated at each stage of the procurement process under the new 2014 EU public procurement Directives was specifically explained. Thereafter, the scope for sustainable development objectives into PPPs was investigated. How sustainability concerns can be integrated into tender procedures for the award of PPP contracts, highlighting the role played by each procurement phase in the inclusion of sustainable development considerations in such schemes, was discussed as well. Attention was paid to how the planning, award, structure, operation and management of these public-private collaborations can be shaped upon sustainable considerations. Furthermore, how public sector financial management choices may influence the integration of sustainable concerns in these complex, long-term public contracts was described as well. Overall, the focus was put on how sustainability considerations can be integrated into PPPs in order to show their potentials in the generation of socio-environmental benefits.

Chapter III showed that through an effective integration of sustainable development concerns, PPPs have the actual capability of delivering socio-environmental benefits. Moreover, it explained that the latter can be intentional or unintentional and that they vary according to the specific structure of the public-private scheme adopted and the public service and/or infrastructure delivered. In order to better identify them, socio-environmental benefits were conceptualized into three macro-categories, namely accelerated delivery benefits, enhanced delivery benefits and wider socio-environmental benefits. Then, after recalling that socio-environmental benefits can present themselves in various ways and that they can be effectively promoted by PPPs that integrate in their structure sustainable development considerations, Chapter III highlighted the difficulties related to their measurement, which still hamper their full consideration. In fact, there is no consensus on how socio-environmental benefits can best be calculated. In principle, environmental benefits are generally measurable, while social ones, instead, are by nature more difficult to measure. Nonetheless, ongoing studies and researches keep on putting efforts into finding ways through which both of them can be measured.

Finally, Chapter IV examined if the previous theoretical and academic discourse could be validated on practical grounds, namely if PPPs are actually capable of promoting sustainable 
development objectives in the every-day practice through the generation of socio-environmental benefits. To this end, first, the room for sustainable development concerns in public contracts and concessions recognised by the relevant policies and national laws of the Member States studied was explored. For each jurisdiction, an overview of the legal and policy framework that allows space for sustainability considerations into public contracts was provided. Secondly, three representative case studies for each considered Member State were carried out. These are examples of PPP arrangements structured in a way that actually fosters the generation of socio-environmental benefits and, thus, promotes sustainable development objectives. This empirical research allowed the identification of the socio-environmental benefits generated by each PPP project studied as well as the tender and contractual strategies, inherent to the particular structure of the PPPs considered, which allow the generation, along with economic gains, of sustainable benefits. Thus, this study showed that PPP arrangements can effectively be structured in order to promote sustainable development goals.

A comparative analysis of the UK, Dutch and Italian case studies was then carried out. This led to the identification of the overall key contractual and tender strategies that allowed the integration of sustainability concerns within the considered PPP arrangements.

To conclude, a comparative analysis of such strategies - disengaged as much as possible from the specific context of the projects in which they were used - allowed the identification of general guidelines or reference points for public and private actors willing to award, structure and manage PPPs that promote sustainable development objectives. These will be outlined here below under paragraph 3.

\section{Acknowledgments and Achievements of this Study with respect to the Research Questions.}

This study showed that PPPs can be considered as public services and/or infrastructure delivery models actually capable of promoting sustainable development goals through the generation of socio-environmental benefits. The following are the main reasons for this. First, (i) EU public contracts and concessions law - as well as the relevant legal regimes of the Members States studied - do allow and encourage spaces for the integration of socio-environmental considerations within public contracts and concessions. ${ }^{3}$ Secondly, (ii) PPPs have attached, or better, are characterised by inherent features that - if actually endorsed to pursue sustainability goals - are capable of effectively fostering also sustainable development objectives in the delivery of public infrastructure and/or services.

PPPs represent a public procurement option, which re-emerged in the last decades. They can count on several different formalizations: numerous legal options, types, structures and strategies are available. Public-private schemes and related risks vary from place to place and from project to project. PPPs may be described as legal arrangements lying somewhere between public provision and privatization. In fact, until recently, public services and infrastructure facilities were considered public goods. Hence, they were built by the public sector, financed by taxpayers and managed by public entities. It was more or less in the 1990s that several jurisdictions began to resort to PPPs. These arrangements link together finance, construction, operation and management into one single long-term contract between the contracting authority and a private operator. During the contract

\footnotetext{
${ }^{3}$ These spaces where explored in Chapters III and IV. 
life, the private sector receives a set of revenues as compensation for the first investment, operational costs and maintenance expenses. Depending on the contract type chosen, the set of incomes may be users' fees, payments from the contracting authority or a combination of both. At the end of the contract, the asset may be transferred to the public sector.

The use of PPPs will likely continue to increase. However, at times this may happen for the wrong reasons and in wrong ways. It is, for instance, the case of PPPs used to elude public finance restrictions or to pursue exclusively profit objectives without considering socio-environmental concerns. In addition, as PPPs have spread throughout the globe during the last decades, PPPs' practice went way ahead of a clear understanding of their legal, economic, political and policy implications. Governments and private actors took advantage of the opportunities offered by PPP schemes to advance their own interests and agendas. Therefore, today more than ever, there is the need to move towards a smarter understanding, use and governance of PPPs. It is within this picture that this study explored if PPPs can act as true and effective public delivery means from a sustainable point of view. This thesis investigated their ability to generate - along with economic gains - socio-environmental benefits. It was assessed that PPPs indeed have scope for large welfare and environmental gains given that their inherent features and related structures allow room for opportunism in this respect. Especially in complex infrastructure and service projects, PPPs do have the potential of playing an important and positive role in the delivery of sustainability objectives.

Overall, it was found that including sustainable development considerations within PPP schemes entails a number of conceptual and practical challenges that vary from case to case and from sector to sector. Moreover, the little agreement on the precise boundaries of the concept of sustainability may lead to uncertainties on the ways through which it should be balanced with other important objectives such as transparency, fairness and competition. Nonetheless, there is a high motivation to pursue sustainable development goals through PPPs. The Table below, displayed in Chapter III, sums up the role that the various procurement phases can play in the inclusion of sustainable development considerations into PPPs. It is a general reference framework that needs to be adapted on a case-by-case basis, tailored to the specific PPP legal type used and the project's characteristics.

\begin{tabular}{|c|l|}
\hline Phase & \multicolumn{1}{|c|}{ Suggested measures } \\
\hline $\begin{array}{c}\text { Budgeting and } \\
\text { Planning }\end{array}$ & $\begin{array}{l}\text { The public sector should opt for a multi-year, performance or availability budgeting and } \\
\text { evaluate long-term sustainable needs with stakeholders and end-users. Life-cycle costs } \\
\text { should also be considered. }\end{array}$ \\
\hline Market examination & $\begin{array}{l}\text { The public sector should properly advertise its needs and look for detailed input from } \\
\text { potential private partners, consult other public authorities for advice and use the collected } \\
\text { information to clearly identify the scope and specifications of the contract that has to be } \\
\text { awarded. Any competitive advantage to economic operators should be avoided. }\end{array}$ \\
\hline Choice of Procedure & $\begin{array}{l}\text { The public sector should choose the level of interaction needed to select the best solution. } \\
\text { The contracting authority should also verify the available time and resources and } \\
\text { preferably opt for the competitive dialogue procedure or the CPN. The competitive } \\
\text { in order to draft specifications. }\end{array}$ \\
\hline $\begin{array}{c}\text { Technical } \\
\text { Specifications }\end{array}$ & $\begin{array}{l}\text { The public sector should lay down clear contractual requirements and, if possible, allow } \\
\text { variants and effectiveness monitoring. }\end{array}$ \\
\hline
\end{tabular}




\begin{tabular}{|c|l|}
\hline Selection & $\begin{array}{l}\text { The public sector should apply selection criteria according to the specific goals that have } \\
\text { to be achieved, verify tenderers prior contractual performances and the content of the } \\
\text { European Single Procurement Document. }\end{array}$ \\
\hline Evaluation & $\begin{array}{l}\text { The public sector should set award criteria and weightings, which adequately reflect the } \\
\text { qualitative, environmental and/or social needs identified. The contracting authority } \\
\text { should apply minimum scores to such criteria and use a life-cycle costing approach } \\
\text { whenever there is available supporting data. }\end{array}$ \\
\hline Contract terms & $\begin{array}{l}\text { Contract terms should allocate risks to the party better capable of managing them. } \\
\text { Standard conditions should be avoided as they may hinder the achievement of project- } \\
\text { tailored sustainable goals. }\end{array}$ \\
\hline $\begin{array}{c}\text { Contract } \\
\text { management }\end{array}$ & $\begin{array}{l}\text { The public sector should apply adequate and proportionate performance indicators } \\
\text { allowing sufficient time and resources for compliance monitoring. }\end{array}$ \\
\hline
\end{tabular}

It has to be recalled that sustainability and innovation are overall aspects that specifically characterise the private market by feeding competition among economic operators through costs reductions and quality improvements. They allow consumers to enjoy enhanced products, infrastructure or services. Instead, innovation and sustainability are not usually a priority in public markets. In the public sector the demand is institutionalised and it normally works upon budgetary considerations, rather than on price mechanisms. Public markets are based on the achievement of specific tasks, above all, the pursuit of the public interest. Thus, products, infrastructure and services are seldom innovative, sustainable or technologically advanced and the price is mostly defined in tenders. Often innovation and sustainability do not fit well within the legal fundamentals of the procurement regime, being also expensive in terms of capital and resources needing many years to recoup the investments made. In addition, the desirability for sustainability and innovation in public contracts is hindered by the difficulties related to their regulation. They are, in fact, aspirational and intangible elements, which do not typically adapt themselves to the classic procedural uniformity of award procedures. ${ }^{4}$

Through PPPs innovation and sustainability may, however, find their way. Private partners' incentives create a favourable environment for innovation and sustainability, being the latter distinctive features of complex contractual formats. PPPs are capable of balancing price, cost, risk, quality and performance with ongoing asset's improvements in an effective way. Public-private models and mechanisms can easily be shaped upon sustainable demands. Their planning, structure and management allow potentially large spaces for the integration of sustainability considerations. Given the current inherent features of contracting authorities' structures and organizations (e.g. budget restraints, general lack of skills and knowledge in carrying out especially complex, innovative and sustainable projects), the public sector is highly interested in availing itself of private sector's advantages to pursue - in a cooperatively way - public interests' objectives, which embed also sustainable development considerations.

The following are the main PPPs' features that are capable of effectively fostering sustainable development objectives in the delivery of public infrastructure and/or services:

\footnotetext{
${ }^{4}$ See, in this respect, C H Bovis, Editorial, [2015] EPPPL. 
- extra budgetary funds for investments in sustainable and innovative practices;

- private know-how and skills applied in every project's phase for sustainable and innovative solutions;

- allocation of tasks and risks to the party better capable of handling them;

- payment mechanisms based on availability and performance targets. Incentives for over performances and penalties for under-performances;

- long duration of contractual relationships. Investments are made in more coherent projects with a high level of maintenance over time.

Therefore, contracting authorities across the EU, in order to promote the submission of sustainable, innovative and flexible tenders and, thus, the structure of PPPs that effectively embed socioenvironmental concerns, should exchange data on the following:

- efficient multi-year, performance or availability budgeting schemes;

- effective output specifications in terms of environmental and social sustainability;

- award criteria (and related weighting) that adequately reflect the qualitative, environmental and/or social needs identified;

- well-functioning life-cycle costing approaches and relevant available supporting data;

- contract terms that allocate risks to the party better capable of managing them;

- monitoring systems which apply adequate and proportionate performance indicators and allow sufficient time and resources for compliance monitoring.

Capacity building measures and supporting institutions, however, need to be into place and functioning. In fact, the overall ability of PPPs to integrate and promote sustainable objectives largely depends on the efficiency and innovation capacity of the private sector. Thus, an incentivebased regulation is fundamental. A system based on improved outputs that defines prices in a sustainable manner, sets boundaries to monopoly profits, increases incentives for the private sector to be more efficient and innovative, while reducing costs, should be promoted.

\section{Conclusive Remarks and Findings.}

As above-mentioned, this thesis found that PPPs are actually capable of promoting sustainable development considerations through the generation of socio-environmental benefits.

First, the studied national public contracts and concessions law regimes do allow the inclusion of sustainability objectives into the structure of public contracts, hence, also into PPPs. ${ }^{5}$ All the three Member States considered enacted policies and provisions that highly support the EU's goal for smart, innovative and sustainable public procurement. There is an overall homogenous recognition of the spaces for sustainable concerns within public contracts. Therefore, the key question becomes, rather than the identification of 'the most efficient system', ${ }^{6}$ the identification of

\footnotetext{
${ }^{5}$ See Chapter IV.

${ }^{6}$ Which would entail the measurement of outputs (i.e. socio-environmental benefits) which are by nature normally intangible and abstract concepts and on which ongoing studies and researches keep on putting efforts into finding ways through which measure them. See paragraph 5.4, Chapter III.
} 
'the most effective tender and contractual strategies' capable of actually including sustainable development considerations within PPPs, allowing them to deliver also socio-environmental benefits. This cannot be anyway done aprioristically, but on a case-by-case basis taking into account all the specific project-related features and objectives. ${ }^{7}$ Nonetheless, the study of the public contracts and concession law regimes of the Member States considered showed that the UK and the NL could learn from the Italian experience. As seen, the Italian legislator - while transposing the 2014 EU public procurement Directives - enacted an ad hoc regulation specifically dedicated to PPPs, which supports, inter alia, the inclusion of sustainable development considerations within these public contracts. Therefore, the UK and the NL could follow the Italian example and foresee an ad hoc regulation of PPPs, which would increase legal certainty in a field characterised by a high level of complexity.

Secondly, PPPs have attached, or better, are characterised by inherent features that - if actually endorsed to pursue sustainability goals - are capable of effectively fostering sustainable development objectives in the delivery of public infrastructure and/or services.

Thirdly, an empirical and field research showed that PPP projects can be structured in a way that potentially largely embeds sustainability concerns and, thus, fosters the generation of socioenvironmental benefits. ${ }^{8}$ Moreover, the PPP case studies presented in this thesis allowed the identification of the specific tender and contractual strategies through which sustainability considerations were integrated in the PPPs considered, thereby allowing the generation of socioenvironmental benefits.

With respect to the case studies presented in this thesis, it may be argued that they lack a 'generalization attitude' and, hence, that they do not allow general conclusions to be drawn. However, the following aspects have to be taken into consideration:

i. a comparative analysis of the above-mentioned tender and contractual strategies - disengaged as much as possible from the specific context of the projects in which they were used - does allow the identification of general key tender and contractual strategies. These will be presented here below and aim at serving as guidelines or as reference points for EU public and private actors willing to award, structure and manage PPPs capable of actually promoting sustainable development objectives;

ii. moreover, three case studies per each Member State considered allowed the provision of sufficient evidence to support the statement according to which if PPPs integrate in a smart way sustainability considerations within their structures by implementing, on a case-by-case basis, the identified strategies, a link between the perceived cause (i.e. the PPP) and the perceived effect (i.e. the generation of socio-environmental benefits) can be drawn;

iii. furthermore, the ability of PPPs to deliver socio-environmental benefits ultimately varies according to the extent to which they integrate sustainability concerns within their structures and, thus, according to how the means provided by the applicable laws are implemented. In this respect, public procurement regimes have shown to be - in the Member States studied overall homogenous with respect to the recognition of spaces for sustainable concerns within public contracts and concessions. Moreover, PPPs' features

\footnotetext{
${ }^{7}$ Overall strategies that can serve as reference models in this respect will be highlighted here below.

${ }^{8}$ These were identified, for each case study, in Chapter IV. 
that - if actually endorsed to pursue sustainability goals - are capable of effectively fostering sustainable development objectives, are typical of any PPP model. Therefore, three case studies per Member State were deemed sufficient to identify overall tender and contractual strategies that - if effectively integrated into PPP schemes to pursue sustainability goals - allow the delivery of socio-environmental benefits;

iv. finally, any research has to set its boundaries and identify its limits. Therefore, also this thesis had to, inter alia, limit the number of case studies per Member State in the light of the scope of this research. In this respect, three case studies per country were deemed sufficient to, on the one hand, pursue one of the main research objectives of this thesis (i.e. the identification of the concrete strategies through which public and private actors can actually integrate sustainability concerns within PPPs' structures and, therefore, deliver socio-environmental benefits); and, on the other hand, draw concrete conclusions to this research without leaving it on a mere academic and theoretical level.

To conclude, hereunder key general tender and contractual strategies, which may allow the inclusion of sustainable development concerns into PPPs will be outlined. These emerged from a comparative analysis of the specific strategies used in the PPP projects presented in Chapter IV and aim at serving as guidelines for public and private sectors across the EU in the award, structure and management of PPPs capable of promoting sustainable development objectives.

Tender's strategies.

Tenders' strategies that allow the embedding of sustainability considerations into PPPs overall consist of the following. Contract notices that require:

- the submission of sustainable, innovative and flexible proposals;

- the delivery of projects in accordance with defined output specifications (drafted in terms of both environmental and social sustainability); and

- the submission of a comprehensive life-cycle maintenance programme that includes scheduled and reactive maintenance activities.

Moreover, criteria used to evaluate tenders that concern the following:

- quality of the project (including the use of sustainable materials in the construction phase);

- time-schedule for the completion of the project;

- performance and technical value of the project;

- usage and maintenance process;

- management plan (including an environmental and health and safety management plan);

- environmental impact of the project (including energy management initiatives);

- social benefits for the society. 
Contractual strategies.

The contractual terms and conditions that generally allow the integration of sustainability considerations into PPP arrangements concern the different project's phases and can overall be described as follows. Depending on the country and/or the sector involved and/or the specific legal scheme chosen to carry out the project under a PPP, certain contractual provisions may vary and provide for a different and/or additional content.

Works.

Works must meet set availability criteria and the contracting authority verifies whether they are carried out accordingly. Additionally, PPP contracts should provide for financial penalties for every day of delay in the completion of works.

In DBFM contracts, normally project plans are subject to a probabilistic assessment in accordance with specific analytical methods and the contractor's evaluations must prove their feasibility. PFIs generally allow the contracting authority to accept an early handover of the infrastructure or service commencement, if it provides VfM. If this is case, the private party is entitled to a bonus payment. Concessions contracts may also foresee that the contractor is entitled to a bonus premium for each day of early delivery of the infrastructure or service. Such a bonus payment is determined according to the benefits enjoyed by the contracting authority as a result of the early completion and delivery of the infrastructure or service.

Strict service levels and incentive mechanisms.

Overall, the contractor must comply with the applicable legislative standards and the contract's quality-related obligations. Additionally, the contractor must achieve specific performance levels that were set in advance. PPP contracts should provide for performance levels through the specification of output requirements.

In PFIs, the contracting authority normally rewards events of over performance - with respect to the set levels - through bonus payments or reward points (if over performance offers VfM). DBFM contracts generally provide as well for bonus payments, for instance, when no deductions for underperformance are applied on the payments made by the public party in a given period. DBFM and concessions contracts may provide that if the contractor breaches its contractual obligations without remedying them within a set period, the contracting authority can rectify the contractor's default itself, have it rectified by a third party or terminate the agreement. In the first two cases, the contractor must pay the contracting authority an amount equal to the payment made to the third parties or the costs borne to remedy the breach, increased by any further damage and of a surcharge.

Payment mechanism.

1. Clear definitions of availability and performance targets.

PPP contracts have to define the concept of availability and the levels of performance required. They must detail which are the unacceptable levels of performance and set out the relevant thresholds. In PFIs, customer satisfaction surveys may be also foreseen, while this is normally not the case for DBFM and concessions contracts.

2. No payments are made until the service or infrastructure is completed and operational and payments are not executed prior to the period to which they refer to.

3. Cash deductions or penalties have to be envisaged in case of unavailability and underperformance. The payment mechanism has to financially regulate the consequences of service's 
failure. Penalty deductions may vary according to the type of failure or project area affected. The contractor has to carry out performance audits.

4. The functioning of the payment mechanism should not substitute claims for specific performance or injunctive reliefs. Furthermore, the contracting authority has to have the possibility to rely on adequate termination rights in the event of unavailability or service underperformance. In addition, lenders must have their own remedies.

Quality management.

PPPs have to provide for a quality management strategy that allows the contracting authority to obtain the infrastructure or service in accordance with set output specifications. The contracting authority has to carry out periodical controls of the contractor's quality management system. Moreover, the contractor must provide data, assistance and access whenever the contracting authority requires it. The contractor must submit adequate information to assess the efficiency, effectiveness and sustainability of the service's management.

Generally, in DBFM contracts the contractor has to obtain a quality system certificate and carry out a process assessment according to specific standards. DBFM and concession contracts normally foresee that the contractor's management system includes an environmental and safety management plan according to specific standards. Additionally, they provide for financial and non-financial mitigating measures that have to be implemented according to defined work protocols.

Constant improvement of the efficiency of the service or infrastructure during the contract life.

PPP contracts should expressly provide for a constant cooperation between the contracting authority and the contractor, which is aimed at identifying and improving performance, efficiency and effectiveness. In this respect, periodical efficiency reviews may be carried out. Moreover, the contractor should be required to submit improvement reports identifying measures undertaken to advance effectiveness, as well as any opportunity for improvement.

Promotion of social value.

Overall, PPP contracts should provide that the private party, and each contractor-related party, complies with the relevant national and EU laws in the field of social protection. DBFM contracts normally emphasise more the private party's compliance with the relevant domestic and EU laws in the field of environmental protection. Moreover, DBFM contracts foresee that the contractor must coordinate itself with stakeholders and provide them with timely information on the project's outcomes before they are directly confronted with them. Likewise, PFIs and concessions contracts generally foresee that the contractor must take stakeholders' needs into account and provide them with any information on the conditions, quality and functioning of the service or infrastructure delivered.

Lifecycle fund.

PFIs may foresee that contracting authority's payments are allocated to cover the contractor's future maintenance costs through the creation - by the private party - of a lifecycle fund. The latter anticipates the relevant future maintenance expenditures. The contractor renovates or replaces assets by tapping into the lifecycle fund in accordance with a lifecycle maintenance plan agreed upon by the contracting authority. The contractor must prepare also a lifecycle funding report. All risks related to lifecycle arrangements - which are verified by an independent and external body - are borne by the contractor. 
Maintenance.

PPP arrangements should provide that maintenance is at the contractor's risk. Maintenance is required to ensure that the private party keeps the infrastructure or service delivered at the set standards and that it meets the specific output specifications throughout the contract life. The contractor should be generally required to submit a maintenance schedule or a plan specifying all maintenance works to be carried out. The contracting authority then ensures compliance - by the contractor - with maintenance requirements through payment and termination provisions. 


\section{BIBLIOGRAPHY}

\section{Case law}

- C-120/78, Rewe-Zentral AGv Bundesmonopolverwaltung für Branntwein, [1979] 00649;

- C-810/79, Peter Überschär v Bundesversicherungsanstalt für Angestellte, [1980] I-02747;

- C-31/87, Gebroeders Beentjes BV v State of the Netherlands, [1988] 04635;

- C-45/87, Commission of the European Communities v Ireland, [1988] 04929;

- C-243/89, Commission of the European Communities v Kingdom of Denmark, [1993] I03353;

- C-340/89, Irène Vlassopoulou v Ministerium für Justiz, Bundes- und Europaangelegenheiten Baden-Württemberg, [1991] I-02357;

- C-76/90, Manfred Säger v Dennemeyer \& Co. Ltd., [1991] I-04221;

- C-330/91, The Queen v Inland Revenue Commissioners, ex parte Commerzbank AG, [1993] I-04017;

- C-389/92, Ballast Nedam Groep NV v Belgian State, 1994 I-01289. C-176/98, Holst Italia SpA v Comune di Cagliari, [1999] I-08607;

- C-360/96, Gemeente Arnhem v BFI Holding BV, [1998] I-06821;

- C-324/98, Telaustria Verlags GmbH and Telefonadress GmbH v Telekom Austria AG, [2000] I-10745;

- C-225/98, Commission of the European Communities v French Republic, [2000] I-07445;

- C-379/98, PreussenElektra AG v Schhleswag AG, in the presence of Windpark Reußenköge III GmbH and Land Schleswig-Holstein, [2001] I-02099;

- C-513/99, Concordia Bus Finland Oy Ab, formerly Stagecoach Finland Oy Ab v Helsingin kaupunki and HKL-Bussiliikenne, [2002] I-07213;

- C-280/00, Altmark Trans GmbH and Regierungspräsidium Magdeburg $v$ Nahverkehrsgesellschaft Altmark GmbH, and Oberbundesanwalt beim Bundesverwaltungsgericht, [2003] I-07747;

- Case T-169/00, Esedra SPRL v Commission of the European Communities, [2002] II-00609;

- C-448/01, EVN AG and Wienstrom GmbH v Republik Österreich, [2003] I-14527;

- C-314/01, Siemens AG Österreich and ARGE Telekom \& Partner v Hauptverband der österreichischen Sozialversicherungsträger, [2004] I-02549;

- C-422/02 P, Europe Chemi-Con (Deutschland) GmbH v Council of the European Union, [2005] I-00791;

- T-345/03, Evropaïki Dynamiki v Commission, [2008] II-00341;

- C-26/03, Stadt Halle, ECR [2005], I-1;

- C-458/03, Parking Brixen GmbH v Gemeinde Brixen and Stadtwerke Brixen AG, [2005] I08585 ;

- C-231/03, Consorzio Aziende Metano v Comune di Cingia de’ Botti, [2005] I-07287; 
- C-234/03, Contse SA, Vivisol Srl and Oxigen Salud SA v Instituto Nacional de Gestión Sanitaria (Ingesa), formerly Instituto Nacional de la Salud, [2005] I-09315;

- C-21/03 and C-34/03, Fabricom SA v Belgian State, [2005] I-01559;

- C-410/04, ANAV v Comune di Bari and AMTAB Servizio SpA, [2006] I-03303;

- Joined cases C-226/04 and C-228/04, La Cascina Soc. coop. arl and Zilch Srl v Ministero della Difesa and Others (C-226/04) and Consorzio G. f. M. v Ministero della Difesa and La Cascina Soc. coop. arl (C-228/04), [2006] I-01347;

- Case T-148/04, TQ3 Travel Solutions Belgium SA v Commission of the European Communities, [2005] II-02627;

- C-382/05, Commission of the European Communities v Italian Republic, [2007] I-06657;

- C-399/05, Commission of the European Communities v Hellenic Republic, [2007] I-00101,

- T-331/06, Evropaïki Dynamiki - Proigmena Systimata Tilepikoinonion Pliroforikis kai Tilematikis AE v European Environment Agency (AEE), Reports of Cases, [2010] II-00136, Appeal Case before the Court of Justice C-462/10 P;

- C-454/06, Pressetext Nachrichtenagentur GmbH v Republik Österreich (Bund), [2008] I04401;

- C-532/06, Emm. G. Lianakis AE, Sima Anonymi Techniki Etaireia Meleton kai Epivlepseon and Nikolaos Vlachopoulos v Dimos Alexandroupolis and Others, [2008] I-00251;

- C-573/07, Sea Srl v Comune di Ponte Nossa, [2009] I-08127;

- C-437/07, Commission of the European Communities v Italian Republic, [2008] I-00153;

- C-199/07, Commission of the European Communities v Hellenic Republic, [2009] I-10669.

- C-196/08, Acoset SpA v Conferenza Sindaci e Presidenza Prov. Reg. ATO Idrico Ragusa and Others, [2009] I-09913;

- C-206/08, Wasser und Abwasserzweckverband Gotha und Landkreisgemeinden (WAZV Gotha) v Eurawasser Aufbereitungs und Entsorgungsgesellschaft mbH, [2009] I-08377;

- C-451/08, Helmut Müller GmbH v Bundesanstalt für Immobilienaufgaben, [2010] I-02673;

- C-274/09, Privater Rettungsdienst und Krankentransport Stadler v Zweckverband für Rettungsdienst und Feuerwehralarmierung Passau, [2011] I-01335;

- C-348/10, Norma-A SIA and Dekom SIA v Latgales plānošanas Region, [2011] I-10983;

- C-368/10, European Commission v Kingdom of the Netherlands, published in the electronic Reports of Cases (Court Reports - general);

- C-95/10, Strong Segurança SA v Município de Sintra and Securitas-Serviços e Tecnologia de Segurança, [2011] I-01865;

- C-138/11, Compass-Datenbank GmbH v Republik Österreich, published in the electronic Reports of Cases (Court Reports - general);

- C-218/11, Észak-dunántúli Környezetvédelmi és Vizügyi Igazgatóság (Édukövízig) and Hochtief Construction AG Magyarországi Fióktelepe $v$ Közbeszerzések Tanácsa Közbeszerzési Döntőbizottság, published in the electronic Reports of Cases (Court Reports general);

- C-221/12, Belgacom NV v Interkommunale voor Teledistributie van het Gewest Antwerpen (INTEGAN) and others, published in the electronic Reports of Cases (Court Reports general);

- C-573/12, Ålands vindkraft AB v Energimyndigheten, published in the electronic Reports of Cases (Court Reports - general); 
- C-561/12, Nordecon AS and Ramboll Eesti AS v Rahandusministeerium, published in the electronic Reports of Cases (Court Reports - general);

- C-358/12, Consorzio Stabile Libor Lavori Pubblici v Comune di Milano, published in the electronic Reports of Cases (Court Reports - general);

- Joined cases C-204/12 to C-208/12, Essent Belgium NV v Vlaamse Reguleringsinstantie voor de Elektriciteits- en Gasmarkt, published in the electronic Reports of Cases (Court Reports - general);

- C-552/13, Grupo ositalario Quirón SA v Departamento de Sanidad del Gobierno Vasco and Instituto de Religiosas Siervas de Jesús de la Caridad, published in the electronic Reports of Cases (Court Reports - general);

- C-549/13, Bundesdruckerei GmbH v Stadt Dortmund, published in the electronic Reports of Cases (Court Reports - general);

- C-115/14, RegioPost GmbH \& Co. KG v Stadt Landau in der Pfalz, published in the electronic Reports of Cases (Court Reports - general);

- Cons. Stato, Sez. V. [2004] n. 7555, in Foro Amm. CDS, 3244;

- Cons. Stato, Sez. V, [2007] n. 256, in www.giustizia-amministrativa.it;

- Cons. Stato, Sez. V, [2009] n. 4028, in Giur. It., 456;

- Corte Cost. n. 331/2003, Foro it., [2004], I, 1364.

\section{Legislation}

- Charter of Fundamental Rights of the European Union (2012/C 326/02);

- Concession Contracts Regulations 2016;

- Council Decision, 18 December 2006, on the conclusion of the Agreement between the Government of the United States of America and the European Community on the coordination of energy-efficiency labelling programmes for office equipment (2006/1005/EC);

- Council Directive 93/37/EEC of 14 June 1993 concerning the coordination of procedures for the award of public works contracts, O J L 199;

- Directive 2004/17/EC of the European Parliament and of the Council of 31 March 2004 coordinating the procurement procedures of entities operating in the water, energy, transport and postal services sectors, OJ L 134, 30.4.2004;

- Directive 2004/18/EC of the European Parliament and of the Council of 31 March 2004 on the coordination of procedures for the award of public works contracts, public supply contracts and public service contracts, OJ L 134, 30.4.2004;

- Directive 2007/66/EC of the European Parliament and of the Council of 11 December 2007 amending Council Directives 89/665/EEC and 92/13/EEC with regard to improving the effectiveness of review procedures concerning the award of public contracts (Text with EEA relevance ), OJ L 335;

- Directive 2009/28/EC of the European Parliament and of the Council of 23 April 2009 on the promotion of the use of energy from renewable sources and amending and subsequently repealing Directives 2001/77/EC and 2003/30/EC (Text with EEA relevance),OJ L 140, 5.6.2009; 
- Directive 2009/28/EC of the European Parliament and of the Council of 23 April 2009 on the promotion of the use of energy from renewable sources and amending and subsequently repealing Directives 2001/77/EC and 2003/30/EC (Text with EEA relevance), OJ L 140, 5.6.2009;

- Directive 2009/33/EC of the European Parliament and of the Council of 23 April 2009 on the promotion of clean and energy-efficient road transport vehicles (Text with EEA relevance), OJ L 120, 15.5.2009;

- Directive 2009/33/EC of the European Parliament and of the Council of 23 April 2009 on the promotion of clean and energy-efficient road transport vehicles (Text with EEA relevance), OJ L 120, 15.5.2009;

- Directive 2010/75/EU of the European Parliament and of the Council of 24 November 2010 on industrial emissions (integrated pollution prevention and control) Text with EEA relevance, OJ L 334;

- Directive 2012/27/EU of the European Parliament and of the Council of 25 October 2012 on energy efficiency, amending Directives 2009/125/EC and 2010/30/EU and repealing Directives 2004/8/EC and 2006/32/EC Text with EEA relevance, OJ L 315, 14.11.2012;

- Directive 2014/23/EU of the European Parliament and of the Council of 26 February 2014 on the award of concession contracts Text with EEA relevance, OJ L 94;

- Directive 2014/24/EU of the European Parliament and of the Council of 26 February 2014 on public procurement and repealing Directive 2004/18/EC Text with EEA relevance, OJ L 94;

- Directive 2014/25/EU of the European Parliament and of the Council of 26 February 2014 on procurement by entities operating in the water, energy, transport and postal services sectors and repealing Directive 2004/17/EC Text with EEA relevance, OJ L 94;

- Legislative Decree n. 163/2006;

- Legislative Decree n. 50/2016;

- Public Contracts Regulations 2015;

- Public Services Act, 2012;

- Regulation (EC) No 66/2010 of the European Parliament and of the Council of 25 November, 2009, on the EU Ecolabel, (Text with EEA relevance), L 27/1.

\section{Books}

- A Deering, The Difference Engine: Achieving Powerful and Sustainable Partnering (Gower, 1998);

- A Jashapara, J Barlow, M Cohen, Y Simpson, Towards Positive Partnering: Revealing the Realities in the Construction Industry (University of Bristol Policy Press, 1997);

- A Mattera, Le marché unique Européen: ses règles, son fonctionnement (Jupiter, 1990);

- A Sanchez Graells, Public procurement and the EU competition rules (Hart Publishing, 2015);

- $\quad$ A Semple, A Practical Guide to Public Procurement (Oxford University Press, 2015);

- B Addis, R Talbot, Sustainable Construction procurement: a guide to delivering environmentally responsible projects (CIRIA, 2001);

- C C Ragin, The Comparative Method: Moving Beyond Qualitative and Quantitative Strategies (University of California Press, 2014); 
- C Edquist, L Hommen, L Tsipouri, Public Technology Procurement and Innovation (Kluwer Academic Publishers, 2000);

- C Egbu, CIB Proceedings 2015: Going north for sustainability: Leveraging knowledge and innovation for sustainable construction and development (IBEA Publications Ltd, 2016);

- C H Bovis, EU public procurement law (Edward Elgar, 2007);

- C H Bovis, Public Private Partnerships (Routledge, 2013);

- C H Bovis, Research Handbook on EU Public Procurement Law (Edward Elgar, 2016);

- C H Bovis, The Liberalization of Public Procurement and its effects on the Common Market (Ashgate, 1998);

- C McCrudden, Buying Social Justice: Equality Government Procurement and Legal Change (Oxford University Press, 2007);

- C Risvig Hamer, Contracts not covered or not fully covered by the Public Sector Directive (DJØF, 2012);

- Commission on Public Private Partnerships, Building Better Partnerships: The Final Report from the Commission on Public Private Partnerships (Institute for Public Policy Research, 2001);

- D Argyriades, O P Dwivedi, J G Jabbra, Public Administration in Transition: a fifty-year Trajectory Worldwide, Essays in Honor of G. E. Caiden, (Edgware, 2007).

- D E Gray, Doing research in the real world (SAGE, 2013);

- D Hunkeler, K Lichtenvort, G Rebitzer, Environmental Life Cycle Costing (CRC Press, 2008);

- D J Maurrasse, Strategic Public Private Partnerships: Innovation and Development (Edward, Elgar, 2014);

- E Elgar, M K Lewis, Public Private Partnerships, The World-Wide Revolution in Infrastructure Provision and Project Finance (Edward Elgar Publishing, 2007);

- E Engel, R D Fischer, A Galetovic, The economics of public-private partnerships: a basic guide (Cambridge University Press, 2014);

- E R Yescombe, Public-Private Partnerships: Principles of Policy and Finance (Elsevier, 2007);

- E S Savas, Privatization and Public-Private Partnerships (Seven Bridges Press, 2000);

- F Lichere, Partenariats public-privé: rapports du XVIIIe congrès de l'Académie Internationale de Droit Comparé / Public-Private Partnership: Reports of the XVIII Congress of the International Academy of Comparative Law (Bruylant, 2011);

- F Lichère, R Caranta, S Treumer, Modernising Public Procurement, The New Directive (DJØF, 2014);

- F Mastragostino, La collaborazione pubblico-privato e l'ordinamento amministrativo: dinamiche e modelli di partenariato in base alle recenti riforme (Giappichelli, 2011);

- F Saitta, Appalti e Contratti Pubblici: Commentario sistematico (Cedam, 2016);

- G C Feroni, Il Partenariato Pubblico-Privato: Modelli e Strumenti (Giappichelli, 2011);

- G Tesauro, Diritto dell'Unione Europea (Cedam, 2010);

- Germà Bel, Trevor Brown, Rui Cunha Marques, Public-Private Partnerships: Infrastructure, Transportation and Local Services (Routledge, 2014);

- Great Britain Cabinet Office, Better Quality Services, A Handbook on Creating Public/Private Partnerships through Market Testing and Contracting Out (HM Government, 1998); 
- Great Britain Cabinet Office, Better Quality Services: Guidance for Senior Managers (TSO, 1998);

- $\quad$ H M Coombs, D E Jenkins, Public Sector Financial Management (Thomson, 2002);

- J D Donaghue, R Zeckhauser, Collaborative Governance: Private Roles for Public Goals in Turbulent Times (Princeton University Press, 2011);

- J Delmon, Public-Private Partnership Projects in Infrastructure: an Essential Guide for Policy Makers (Cambridge University Press, 2011);

- J Gernet, A History of Chinese Civilization (translation J. Foster, Cambridge University Press, 1982);

- J JR Cibinic, R C Nash, C R Yukins, Formation of Government Contracts (CCH, 2011);

- J Sussex, The Economics of the Private Finance Initiative in the NHS (Office of Health Care Economics, 2001);

- J Xia, Sustainable Buildings and Structures: Proceedings of the 1st International Conference on Sustainable Buildings and Structures (CRC Press, 2015);

- J Zachary, Sustainable Community Indicators: Guideposts for Local Planning (Wiley, 1999);

- K Ginther, E Denters, P J I M de Waart, Sustainable Development and Good Governance (Martinus Nijhoff Publishers, 1995);

- $\quad$ K Portney, Taking Sustainable Cities Seriously (MIT Press, 2003);

- L Harvey, D Green, Defining quality, Assessment and Evaluation in Higher Education (Routledge, 1993);

- L Miniace, Partenariato Pubblico-Privato (_oucanprint, 2014);

- M A Abramson, R S Harris, The Procurement Revolution (Rowman \& Littlefiled, 2003);

- M Burnett, Competitive Dialogue and Negotiated Procedures, A Practical Guide (EIPA, 2015);

- M Cafagno, A Botto, G Fidone, G Bottino (eds), Negoziazioni Pubbliche: Scritti su Concessioni e Partenariati Pubblico-Privati (Giuffrè, 2013);

- M J Epstein, Making Sustainability Work: Best Practices in Managing and Measuring Corporate Social, Environmental and Economic Impacts (Greenleaf Publishing Limited, 2008);

- M Klein, Risk, Taxpayers and the Role of the Government in Project Finance (The World Bank, Private Sector Development Department, 1996);

- M Nicolai, Primo rapporto sulla finanza pubblica, Finanza pubblica e federalismo (Maggioli Editore, 2000);

- M P Chiti, Il partenariato pubblico-privato, concessioni, finanza di progetto, società miste, fondazioni (Editoriale scientifica, 2009);

- N Budina, H P Brixi, T Irwin, Public Private Partnerships in the New EU Member States: Managing Financial Risks (World Bank Working Papers, 2007);

- OECD, Effective Delivery of Large Infrastructure Projects (OECD, 2015);

- OECD, Policy Guidance on Resource Efficiency (OECD, 2016);

- OECD, Public Governance Reviews Effective Delivery of Large Infrastructure Projects (OECD, 2015);

- P C Nutt, R W Bachoff, Strategic Management of Public and third Sector Organizations (Jossey-Bass, 1992); 
- P H Pattberg, Public-Private Partnerships for Sustainable Development: Emergence, Influence and Legitimacy (Edward Elgar, 2012);

- P Krugmann, M Obstfeld, International Economics, Theory and Policy (10th ed, Prentice Hall, 2014);

- P Selman, Local Sustainability: Managing and Planning Ecologically Sound Places (St. Martin's Press, 1996);

- P Trepte, Regulating Procurement, Understanding the Ends and Means of Public Procurement Regulation (Oxford University Press, 2007);

- P Vesan, V Sparano, I Partenariati per lo Sviluppo Locale: Logica Politica e Dinamiche di Consolidamento (Carocci, 2009);

- $\quad$ R Caranta, M Trybus, The Law of Green and Social Procurement (DJOF, 2010);

- R Dipace, Partenariato Pubblico Privato e Contratti Atipici (Giuffrè, 2006);

- R Mclvor, The Outsourcing Process, Strategies for Evaluation and Management (Cambridge University Press, 2005);

- S Arrowsmith, J Linarelli, D Jr Wallace, Regulating Public Procurement: National and International Perspectives (Kluwer Law International, 2000);

- S Arrowsmith, P Kunzlik, Social and Environmental Policies in EC Procurement Law: New Directives and New Directions (Cambridge University Press, 2009);

- S Arrowsmith, S Treumer, Competitive Dialogue in EU Procurement (Cambridge University Press, 2012);

- S Arrowsmith, The Law of Public and Utilities Procurement (Sweet and Maxwell, 2014);

- S Kingston, European Perspective on Environmental Law and Governance (Routledge, 2013);

- S M Wheeler, Planning for Sustainability. Creating Liveable, Equitable, and Ecological Communities (Routledge, 2004);

- $\quad$ S Ponzio, I capitolati negli appalti pubblici (Novene, 2006);

- T A Cellucci, A Guide to Innovative Public-Private Partnerships: Utilizing the Resources of the Private Sector for the Public Good (Government Institutes Inc. U.S., 2011);

- World Commission on Environment and Development, From One Earth to One World: An Overview (Oxford University Press, 1987);

- Y Kaya, K Yokobori, Environment, Energy and Economy: Strategies for Sustainability, (United Nations University Press, 1997);

- Y L Doz, G Hamel, Alliance Advantage, The Art of Creating Value through Partnering (Harvard Business School Press, 1998);

- Yseult Marique, Public-Private Partnerships and the Law: Regulation, Institutions and Community (Edward Elgar, October 29, 2014).

\section{Contributions within edited books}

- A Akintoye, M Beck, C Hardcastle, 'Introduction: public-private partnerships in infrastructure development' in A Akintoye, M Beck, C Hardcastle (eds), Public-private partnerships: managing Risks and Opportunities (Blackwell Science Ltd, 2003);

- A Massera, 'I Principi Generali' in M P Chiti, G Corso (eds), Trattato di Diritto Amministrativo Europeo (Giuffrè, 2007);

- A Petretto, 'Partenariato pubblico-privato e finanziamento degli investimenti pubblici' in G C Feroni (ed), Il Partenariato pubblico-privato: modelli e strumenti (Giappichelli, 2011); 
- A Richard, 'Overview of Budget Systems and Public Procurement in OECD Countries' in OECD, Environmental Performance of Public Procurement: Issues of Policy Coherence (OECD, 2003);

- A Sanchez Graelles, 'Are the Procurement Rules a Barrier for Cross-border Trade within the European Market? A view on proposals to lower that barrier and spur growth' in G Skovgaard Ølykke, C Risvig Hansen, C D TvarnØ (eds), EU Public Procurement Modernisation, Growth and Innovation, Discussions on the 2011 proposals for Procurement Directives (Jurist-og Økonomforbundets Forlag, 2012);

- A Sanchez Graells, 'Exclusion, Qualitative Selection and Short-listing in the New Public Sector Procurement Directive 2014/24' in F Lichère, R Caranta, S Treumer (eds), Modernising Public Procurement: the New Directive (DJØF, 2014);

- A Sanchez Graells, 'Rejection of Abnormally Low and Non-Compliant Tenders in EU Public Procurement: A Comparative View on Selected Jurisdictions' in M Comba, S Treumer (eds), Award of Contracts in EU Procurement, European Procurement Law Series (DJØF, 2013);

- A Semple, 'The link to the subject matter: a glass ceiling for sustainable public contracts?' in B Sjåfjell, A Wiesbrock (eds), Sustainable Public Procurement Under EU Law, New Perspectives on the State as Stakeholder (Cambridge University Press, 2015);

- A Wiesbrock, 'Socially responsible public procurement, European Value or national choice?' in B Sjafjell, A Wiesbrock (eds), Sustainable Public Procurement Under EU Law (Cambridge University Press, 2016);

- B Craig, C Wilson, 'PPPs in the European Union' in N Avery (ed), Public-Private Partnerships: A Practical Analysis (Globe Business Publishing, 2010);

- B K Altes, S Vermeulen, 'Netherlands' in J Davey, Amy Gatenby (eds), The Government Procurement Review (Law Business Research, 2016);

- B Li, A Akintoye, 'An overview of Public-Private Partnerships' in A Akintoye, M Beck, C Hardcastle (eds), Public-private partnerships: managing Risks and Opportunities (Blackwell Science Ltd, 2003);

- B Sjafjell, A Wiesbrock, 'Why should Public Procurement be about Sustainability?' in B Sjafjell, A Wiesbrock (eds), Sustainable Public Procurement Under EU Law (Cambridge University Press, 2016);

- C D TvarnØ, 'Public - Private partnerships in the European Union' in R Nielsen, S Treumer, The New EU Public Procurement Directives, [2005] DJØF.

- C D TvarnØ, 'Why the EU Public Procurement Law should contain Rules that allow Negotiation for Public Private Partnerships, Innovation calls for negotiating opportunities' in G Skovgaard Ølykke, C Risvig Hansen, C D TvarnØ (eds), EU Public Procurement Modernisation, Growth and Innovation, Discussions on the 2011 proposals for Procurement Directives, (Jurist-og Økonomforbundets Forlag, 2012);

- C H Bovis, 'Innovation and Public Private Partnerships', in Piga, Tatrai (eds), Public Procurement Policy - The Economics of Legal Relations (Routledge, 2015);

- C H Bovis, 'Public-Private Partnerships: An essential instrument in delivering public services', in S Muller, D Radic (eds), Globalisation, the Nation-State and Private Actors: Rethinking Public-Private Cooperation in Shaping Law and Governance, (Eleven International Publishing, 2013); 
- C H Bovis, 'The Function of Public Procurement in the EU', in Turk, Hoffman, Rowe (eds), Specialised Administrative Law (Oxford University Press, 2016);

- C McCrudden, 'Social Policy Issues in Public Procurement: A Legal Overview' in S Arrowsmith, A Davies (eds), Public Procurement: Global Revolution, Public Procurement: Global Revolution (Kluwer Law International, 1998);

- C Skelcher, 'Governing Partnerships' in G A Hodge, C Greve, A E Boardman Van Dusen (eds), Handbook on Public-Private Partnerships (Edward Elgar, 2012);

- C Skelcher, 'Public-Private Partnerships and Hybridity' in E Ferlie, L J Lynn Jr, C Pollitt (eds), The Oxford Handbook of Public Management (Oxford University Press, 2005);

- D C Dragos, B Neamtu, 'Sustainable Public Procurement in the EU: Experiences and Prospects' in F Lichère, R Caranta, S Treumer (eds), Modernising Public Procurement: the New Directive (DJØF, 2014);

- D Dragos, B Neamtu, R Veliscu, 'Secondary Considerations in Public Procurement in Romania' in R Caranta, M Trybus (eds), The Law of Green and Social Procurement in Europe (DJØF, 2010);

- E H Klijn, 'Public-Private Partnerships: deciphering meaning, message and phenomenon' in G Hodge, C Greve (eds), International Handbook of PPP (Edgar Elgar, 2010);

- F Rubik, D Scheer, E StØ, P Strandbakken, 'Background: theoretical contributions, ecolabels and environmental policy' in F Rubik, P Frankl (eds), The Future of Eco-labelling: Making Environmental Product Information Systems More Effective (Greenleaf Publishing, 2005);

- G F Cartei, 'Le Varie Forme di Partenariato Pubblico-Privato. Il Quadro Generale' G C Feroni (ed), Il Partenariato pubblico-privato: modelli e strumenti (Giappichelli, 2011);

- G Ferrante, P Marasco, 'Equilibrio economico finanziario e valutazione di congruità del contributo pubblico in un'operazione di finanza di progetto' in G Cartei, M Ricchi (eds), Finanza di Progetto, Temi e prospettive, Approfondimenti sistemativi ed interdisciplinari (Editoriale Scientifica, 2010);

- G R Teisman, E H Klijn, 'Public-Private Partnerships in the European Union: Officially Suspect' in S P Osborne (ed), Public-Private Partnerships: Theory and Practice in International Perspective (Routledge, 2000);

- G Sciullo, 'Le dinamiche collaborative tra pubblico e private ed i principi generali di riferimento' in F Mastragostino (ed), La collaborazione pubblico-privato e l'ordinamento amministrativo, Dinamiche e modelli di partenariato in base alle recenti riforme (Giappichelli, 2011);

- H Schebesta, 'EU Green Public Procurement Policy Modernisation Package, Eco-Labelling and Framing Measure' in S Schoenmaekers, W Devroe, N Philipsen (eds), State Aid and Public Procurement in the European Union (Intersentia, 2014);

- L Butler, 'Innovation in Public Procurement: Towards the 'Innovation Union' in F Lichère, R Caranta, S Treumer, Modernising Public Procurement: the New Directive (DJØF, 2014);

- L Butler, 'Qualification, Selection and Exclusion in EU Procurement' in M Burgi, M Trybus, S Treumer (eds), Exclusion, Qualification and Selection in the UK under the Public Contracts Regulations 2015 (DJØF, 2016); 
- M E Comba, 'Green and Social Considerations in Public Procurement Contracts: A Comparative Approach' in R Caranta, M Trybus (eds), in R Caranta, M Trybus (eds), The Law of Green and Social Procurement in Europe (DJØF, 2010);

- M E Comba, 'L'esecuzione delle opere pubbliche, con cenni di diritto comparato' in F G Scoca, F A Roversi Monaco, G Morbidelli (eds), Sistema del diritto Amministrativo Italiano (Giappichelli, 2011);

- M Lu, M Faure, 'The regulation of corporate environmental responsibility' in N J Philipsen, $\mathrm{S}$ E Weishaar, G Xu (eds), Market Integration: The EU Experience and Implications for Regulatory Reform in China (Springer, 2014);

- M Nagelkerke, J Muntz-Beekhuis, 'Competitive Dialogue in the Netherlands' in S Arrowsmith, S. Treumer (eds), Competitive Dialogue in EU Procurement (Cambridge University Press, 2012);

- M Nicolai, W Tortorella, Partenariato Pubblico Privato e Project Finance (Maggioli Editore, 2016);

- M Occhiena, 'Norme di gestione ambientale' in M A Sandulli, R De Nictolis, R Garofoli (eds), Trattato sui contratti pubblici (Giuffrè, 2008);

- M P Chiti, 'I Principi' in M A Sandulli, R De Nictolis, R Garofoli (eds), Trattato sui contratti pubblici (Giuffrè, 2008);

- M Pollitt, "The Declining Role of the State in Infrastructure Investment in the UK" in S V Berg (ed), Private Initiatives in Infrastructure: Priorities, Incentives and Performance (Aldershot, Edward Elgar, 2002);

- M Trybus, 'Public Contracts in European Union internal market law' in R Nogouellou, U Stelkens (eds), Traité de droit compare des contrats publics (Bruylant, 2010);

- M Trybus, 'Sustainability and Value for Money: Social and Environmental Considerations in the United kingdom Public Procurement Law' in R Caranta, M Trybus (eds), The Law of Green and Social Procurement in Europe (DJØF, 2010);

- M Trybus, 'The Promotion of Small and Medium Sized Enterprises in Public Procurement: a Strategic Objective of the New Public Sector Directive?' in F Lichère, R Caranta, S Treumer (eds), Modernising Public Procurement: the New Directive (DJØF, 2014);

- N Bruun, K Ahlberg, 'Public procurement and labor rights: governing by scaremongering' in S Evju (ed), Regulating transnational labor in Europe: the quandaries of multilevel governance (Privatrettsfondet, 2014);

- P Kunzlik, 'Environmental Issues in International Procurement' in S Arrowsmith, A Davies (eds), Public Procurement: Global Revolution (Kluwer Law International, 1998);

- P P Craig, M Trybus, 'Public Contracts: England and Wales' in R Nogouellou, U Stelkens (eds), Traité de droit compare des contrats publics (Bruylant, 2010);

- P Telles, L Butler, 'Public Award Procedures in Directive 2014/24/EU' in F Lichère, R Caranta, S Treumer (eds), Modernising Public Procurement: the New Directive (DJØF, 2014);

- R Caranta, 'I contratti pubblici, in F G Scoca' in F A Roversi Monaco, G Morbidelli (eds), Sistema del diritto amministrativo italiano (Giappichelli, 2004);

- R Caranta, 'Mapping the Margins of EU Public Procurement Law: Covered, Mixed, excluded and special contracts' in F Lichère, R Caranta, S Treumer, Modernising Public Procurement, The New Directive (DJØF, 2014); 
- R Caranta, 'Sustainable Procurement' in M Trybus, R Caranta, G Edelstam (eds), European Union Law of Public Contracts: Public Procurement and Beyond (Buylant, 2014);

- R Caranta, 'The Borders of EU Public Procurement Law' in R Caranta, D Dragos (eds), Outside the EU Procurement Directives - Inside the Treaty? (DJØF, 2012);

- R Caranta, S Richetto, 'Sustainable Procurements in Italy: Of Light and Some Shadows,' in R Caranta, M Trybus (eds), The Law of Green and Social Procurement in Europe (DJØF, 2010);

- R Greco, 'I requisiti di ordine generale' in M A Sandulli, R De Nictolis, R Garofoli (eds), Trattato sui contratti pubblici (Giuffrè, 2008);

- R Invernizzi, 'Specifiche tecniche' in M A Sandulli, R De Nictolis, R Garofoli (eds), Trattato sui contratti pubblici (Giuffrè, 2008);

- R Noguellou, 'Scope and Coverage of the EU Procurement Directives' in M Trybus, R Caranta, G Edelstam (eds), EU Public Contract Law, Public Procurement and Beyond (Bruylant, 2014);

- R Wettenhall, 'The Public-Private Interface: Surveying the History' in G A Hodge, C Greve, The Challenge of Public-Private Partnerships (Edward Elgar, 2005);

- RW McQuaid, 'The Theory of Partnerships, Why have Partnerships' in S P Osborne (ed), Managing Public-Private Partnerships for Public Services: an International Perspective (Routledge, 2000);

- S Arrosmith, 'Application of EC Treaty and Directives to horizontal policies: a critical review' in S Arrowsmith, $\mathrm{P}$ Kunzilk (eds), Social and Environmental Policies in EC Procurement Law: New Directive and New Directions (Cambridge University Press, 2009);

- S Arrowsmith, P Kunzlik, 'Public Procurement and Horizontal Policies in EC Law: General Principles' in S Arrowsmith and P Kunzlik (eds), Social and Environmental Policies in EC Procurement Law (Cambridge University Press, 2009);

- S Arrowsmith, S Treumer, 'Competitive Dialogue in EU Law: A Critical Review' in S Arrowsmith, S Treumer (eds), Competitive Dialogue in EU Procurement (Cambridge University Press, 2012);

- S E Pommer, 'Public-Private Partnerships' in M Trybus, R Caranta, G Edelstam (eds), EU Public Contract Law, Public Procurement and Beyond (Bruylant, 2014);

- S H Linder, P Vaillancourt Rosenau, 'Mapping the Terrain of the Public-Private Policy Partnership' in P Vaillancourt Rosenau (ed), Public-Private Policy Partnerships (MIT Press, 2000);

- S L Conner \& M R Hyman, 'Adjusting prices for externalities' in M Taghian, M Polonsky, C D'Souza (eds), Readings and Cases in Sustainable Marketing: A Strategic Approach to Social Responsibility (Tilde Publishing and Distribution, 2011);

- S Treumer, 'Green Public Procurement and Socially Responsible Public Procurement: An Analysis of Danish Regulation and Practice' in R Caranta, M Trybus (eds), The Law of Green and Social Procurement in Europe (DJØF, 2010);

- W R Van Eck, 'Netherlands' in Global Legal Group (ed), The International Comparative Legal Guide to Public Procurement 2017 (GlG, 2016).

\section{Journal Articles}


- A Akintoye, E Chinyio, 'Private Finance Initiative in the Healthcare Sector: Trends and Risk Assessment' [2005] Engineering Construction and Architectural Management;

- A Akintoye, M Beck, C Hardcastle, 'Achieving best value in private finance initiative project procurement' [2003] Construction Management and Economics;

- A Bala, M Raugei, G Benveniste, C Gazulla et all, 'Simplified Tools for Global Warming Potential Evaluation: When 'Good Enough' Is Best' [2010] International Journal of Life Cycle Assessment;

- A Brown, "The Lawfulness of a National Rule Requiring a Subcontractor of a Bidder for a Public Contract to Pay its Workers a Minimum Wage, Where the Services Will be Carried Out Exclusively in a Lower-Cost Third Country: Case C-549/13 Bundesdruckerei GmbH v Stadt Dortmund' [2015] PPLR;

- A Brown, 'Is a National Law Requiring the Exclusion of Bidders for Non-Payment of Social Security Contributions Exceeding 100 euros Compatible with the EU Treaty and the Principle of Proportionality? Case C-358/12 Consorzio Stabile Libor Lavori Pubblici v Comune di Milano' [2014] PPLR;

- A Brown, 'The Impact of the New Procurement Directive in Large Public Infrastructure Projects: Competitive Dialogue or Better the Devil you Know' [2004] PPLR;

- A C Jr Aman, J C Dugan, 'The Human Side of Public-Private Partnerships: From New Deal Regulation to Administrative Law Management', Iowa Law Review, 2017, 883, 938;

- A Ciric, P Cvetkovic, 'Ex Ante and Ex Post Control of the Public Interest in Public-Private Partnership Agreements', Collection of Papers, Faculty of Law, Nis, 145, 160;

- A Colabianchi, 'Ancora in tema di direttive comunitarie sugli appalti' [1990] Giustizia Civile;

- A Colavecchio, 'Aiuti di Stato, ostacoli al commercio tra Stati membri ed esigenze di tutela dell'ambiente nella giurisprudenza comunitaria. A proposito della sentenza della Corte di giustizia nel caso "Preussenelektra"' [2003] Il Consiglio di Stato;

- A Erridge, J Greer, 'Partnerships and public procurement: building social capital through supply relations' [2002] Public Administration;

- A Goddard, 'Procedures Involving Negotiation in the New Public Procurement Directive: Key Reforms to the Grounds for Use and the Procedural Rules' [2014] PPLR;

- A J Edkins, H J Smith, 'Contractual management in PPP projects: evaluation of legal versus relational contracting for service delivery' [2006] Journal of Professional Issues in Engineering Education and Practice;

- A Jørgensen, A Le Bocq, L Nazarkina, M Hauschild, 'Methodologies for Social Life Cycle Assessment' [2008] International Journal of Life Cycle Assessment;

- A M A Aziz, 'Successful delivery of Public-Private Partnerships for Infrastructure Development' [2007] Journal of Construction Engineering and Management;

- A Ménéménis, 'Le recours à des critères environnementaux dans l'attribution des marchés' [2002] Droit administrative;

- A Ng, M Loosemore, "Risk allocation in the private provision of public infrastructure" [2007] International Journal of Project Management, 25(1), 66, 76;

- A Pollock, J Shaoul, D Rowland, S Player, 'Public Services and the private sector: a response to the IPPR' [2001] Catalyst Working Paper, available at 
http://www.allysonpollock.com/wp-

content/uploads/2013/04/Catalyst_2001_Pollock_PublicServicesPrivateSector.pdf;

- A R Apostol, 'Pre-commercial Procurement in Support of Innovation: Regulatory Effectiveness?' [2012] PPLR;

- A Sanchez Graells, 'The Continuing Relevance of the General Principles of EU Public Procurement Law after the Adoption of the 2014 Concessions Directive' University of Leicester School of Law, Research Paper n. 15-12, 2015, available at SSRN, http://papers.ssrn.com/sol3/papers.cfm?abstract_id=2581683;

- A Saunders, 'Aspects of funding for BOO projects' [1998] Engineering, Construction and Architectural Management;

- A Semple, 'RegioPost judgment: CJEU upholds minimum wage clause' [2015] available at http://www.procurementanalysis.eu/;

- A Semple, 'Reform of EU Procurement Directives and WTO GPA: Forward Steps for Sustainability' [2012] available at SSRN, http://ssrn.com/abstract=2089357 or http://dx.doi.org/10.2139/ssrn.2089357;

- B Flyvbjerg, 'Policy and planning for large-infrastructure projects: problems causes, cures' [2007] Environment and Planning B: Planning and Design;

- B J Brown, 'Global Sustainability: Toward Definition’ [1987] Environmental Management;

- B Li, A Akintoye, P J Edwards, C Hardcastle, 'Critical success factors for PPP/PFI projects in the UK construction industry' [2005] Construction Management and Economics;

- B Li, A Akintoye, P J Edwards, C Hardcastle, 'Perceptions of Positive and Negative Factors Influencing the Attractiveness of PPP/PFI Procurement for Construction Projects in the UK', [2005] Engineering, Construction and Architectural Management;

- B Li, A Akintoye, P J Edwards, C Hardcastle, 'The allocation of risk in PPP/PFI construction projects in the UK' [2005] International Journal of project Management;

- B Neamtu, D C Dragos, 'Sustainable Public Procurement: The Use of Eco-Labels' [2015] EPPPL;

- C Golfinopoulos, 'Legality of National Measures to Promote the Procurement of Energy from Renewable Sources' [2002] PPLR;

- C H Bovis, 'Developing Public Procurement Regulation: Jurisprudence and its Influence on Law Making' [2006] Common Market L Rev;

- C H Bovis, 'Efficiency and Effectiveness in Public Sector Management: the Regulation of Public Markets and Public-Private Partnerships and its Impact on Contemporary Theories of Public Administration' [2013] EPPPL;

- C H Bovis, 'Financing services of general interest, public procurement and State aids: the delimitation between market forces and protection' [2005] European Law Journal;

- C H Bovis, 'The Notion of Public Concession as a Component of Public Private Partnerships' [2007] EPPPL;

- C H Bovis, Editorial, [2015] EPPPL;

- C Kennedy-Loest, 'What can be done at the Preferred Bidder Stage in Competitive Dialogue?' [2006] PPLR;

- C Kidd, 'The Evolution of Sustainability' [1992] Journal of Agricultural and Environmental Ethics; 
- C Koenig, J Kühling, 'EC Control of aid granted through State resources' [2002] European State Aid Law Quarterly;

- D Berlin, 'Une harmonisation partielle empêche-t-elle l'application du traité? Non et oui' [2014] La Semaine Juridique - édition générale;

- D Cumming, 'Government policy towards entrepreneurial finance, Innovation investment funds' [2007] Journal of Business Venturing;

- D Dragos, B Neamtu, 'Sustainable Public Procurement: Life-Cycle Costing in the New EU Directive Proposal' [2013] EPPPL;

- D Grimsey, M K Lewis, 'Evaluating the risks of public-private partnerships for infrastructure projects' [2002] International Journal of project Management;

- D Grimsey, M Lewis, "Public private partnerships and public procurement" [2007] Agenda: A Journal of Policy Analysis and Reform, 14(2), 2007, 171, 188;

- D Heald, "Value for money tests and accounting treatment in PFI schemes" [2003] Accounting, Auditing \& Accountability Journal, 16(3), 342, 371;

- D Heald, G Georgiou, "The Substance of Accounting for Public-Private Partnerships" [2011] Financial Accountability \& Management, 27(2), 217, 247;

- D Hunkeler, 'Societal LCA Methodology and a Case Study' [2006] International Journal of Life Cycle Assessment;

- D Parker, K Hartley, "Transaction costs, relational contracting and public private partnerships: a case study of UK defence" [2003] Journal of Purchasing and Supply Management, 9(3), 97, 108;

- D Podhraški, 'Real Options in Public-Private Partnerships' [2014] EPPPL;

- D Rowland, A M Pollock, 'Understanding the Private Finance Initiative: value for money?' [2003] Developments in Economics;

- D Savvides, 'The Conceptualisation of a Build - Operate - Transfer (BOT) Project', EPPPL, 2016, 130, 141;

- D U Galetta, 'Vizi procedurali e vizi sostanziali al vaglio della Corte di giustizia (che non si pronuncia sulla questione)' [2004] Rivista italiana di diritto pubblico comunitario;

- E Adobati, 'La Corte di giustizia si pronuncia su un appalto pubblico di fornitura subordinato al rispetto di condizioni di carattere ecologico' [2012] Diritto comunitario e degli scambi internazionali;

- E Bennett, P Grohmann, B Gentry, 'Public-Private Partnerships for the Urban Environment, Options and Issues' [1999] United Nations Development Programme (UNDP), Yale University and PPPUE, Working Paper Series, Volume I, available at

- E Chong, F Huet, S Saussier, "Auctions, ex post competition and prices: the efficiency of public-private partnerships" [2006] Annals of Public and Cooperative Economics, 77(4), 521, 554;

- E Chong, F Huet, S Saussier, F Steiner, "Public-private partnerships and prices: Evidence from water distribution in France" [2006] Review of Industrial Organization, 29(1-2), 149, 169 ;

- E Degiorgis, M Glisoni, 'Progetto APE: l'esperienza della provincia di Torino negli acquisti pubblici ecologici’ [2007] Ambiente e Sviluppo;

- E Hochschorner, M Noring, 'Practitioners' use of life-cycle costing with environmental costs--a Swedish study' [2011] International Journal of Life Cycle Assessment; 
- E Korpi, T Ala-Risku, 'Life Cycle Costing: A Review of Published Case Studies' [2008] Managerial Auditing Journal;

- E Maskin, J Tirole, "Public-private partnerships and government spending limits" [2008] International Journal of Industrial Organization, 26(2), 412, 420;

- E Mazuyer, 'La légitimation de la concurrence salariale entre États membres' [2014] Revue Lamy Droit Des Affaires;

- E Uyarra, K Flanagan, 'Understanding the Innovation Impacts of Public Procurement' [2010] European Planning Studies;

- F Berrod, 'Critère écologique. Du maniement prudent du critère écologique dans la sélection des offres' [2004] Europe Février Comm;

- F Nicotra, "Nozione di servizio pubblico nel diritto interno e comunitario" [2015] available at https://www.diritto.it/la-nozione-di-servizio-pubblico-nel-diritto-interno-e-comunitario/;

- F Trionfetti, 'Public Procurement, Market Integration and Income Inequalities' [2001] Review of International Economics;

- G Garzia, 'Bandi di gara per appalti pubblici e ammissibilità delle clausole c.d. "ecologiche"' [2003] Il Foro amministrativo;

- G Hodge, C Greve, 'Public-Private Partnerships: an International Performance Review' [2007] Public Administration Review;

- G Hodge, C Greve, 'Public-Private Partnerships: an International Review' [2007] Public Administration Review;

- G K C Ding, 'Sustainable Construction - the role of environmental assessment tools' [2008] Journal of Environmental Management;

- G M Winch, 'Institutional Reform in British construction: partnering and private finance' [2000] Building Research and Information;

- G Teiseman, E H Klijn, 'Partnerships Agreements: Governmental Rhetoric or Governance Scheme?' [2002] Public Administration Review;

- G Torrisi, "Public infrastructure: definition, classification and measurement issue" [2009] Munich Personal RePEc Archive, 1, 34;

- H Karl, C Orwat, 'Environmental labelling in Europe: European and national tasks' [1999] Environmental Policy and Government;

- H Smyth, A Edkins, 'Relationship Management in the Management of PFI/PPP Projects in the UK' [2007] International Journal of Project Management;

- H Van Ham, J Koppenjan, 'Building Public-Private Partnerships: Assessing and managing risks in port development' [2001] Public Management Review;

- I Zapatrina, 'Sustainable Development Goals for Developing Economies and Public-Private Partnership', EPPPL, 2016, 39, 45;

- I Zapatrina, 'Sustainable Development Goals for Developing Economies and Public-private Partnership' [2016] EPPPL;

- J Arnould, 'A Turning Point in the Use of Additional Award Criteria?' [2001] PPLR;

- J Arnould, 'Environmental Criteria and the EC Procurement Directives: A Note on the Concordia Bus Finland Case' [2003] PPLR;

- J Broadbent, J Gill, R Laughlin, "Identifying and controlling risk: The problem of uncertainty in the private finance initiative in the UK's National Health Service" [2008] Critical Perspectives on Accounting, 19(1), 40, 78; 
- J Broadbent, J Gill, R Laughlin, "Identifying and controlling risk: The problem of uncertainty in the private finance initiative in the UK's National Health Service" [2008] Critical Perspectives on Accounting, 19(1), 40, 78;

- J Broadbent, R Laughlin, 'The Role of PFI in the UK Government's Modernization Agenda' [2005] Financial Accountability and Management;

- J Davey, 'Procedures Involving Negotiation in the New Public Procurement Directive: Key Reforms to Grounds of Use and the Procedural Rules' [2014] PPLR;

- J Froud, 'The Private Finance Initiative Risk, Uncertainty and the State' [2003] Accounting, Organizations and Society;

- J Guasch, J L Laffont, S Straub, "Concessions of infrastructure in Latin America: Government-led renegotiation" [2007] Journal of Applied Econometrics, 22(7), 1267, 1294;

- J Hill, J Collins, 'PFI: Meeting the Sustainability Challenge' [2004] Green Alliance, London;

- J Joël, 'A propos des clauses sociales dans les marchés publics de travaux. Un arrêt étonnant de la Cour de justice des Communautés européennes' [2001] Journal des tribunaux;

- J Kitsos, 'Construction Investments in Public Works through Public Private Partnerships' [2014] EPPPL;

- J Kitsos, 'Privitisation and Public Private Partnerships: Defining the Legal Boundaries from an International Perspective', EPPPL, 2015, 17, 28;

- J Kröger, 'Nationally Exclusive Support Schemes for RES Electricity Production and the Free Movement of Goods' [2013] Journal for European Environmental \& Planning Law;

- J L Guasch Laffont, S Straub, "Concessions of infrastructure in Latin America: Government-led renegotiation" [2007] Journal of Applied Econometrics, 22(7), 1267, 1294;

- J M Belorgey, S Gervasoni, C Lambert, 'Environnement et libre circulation des marchandises' [2001] L'actualité juridique droit administrative;

- J M Hebly, M Klijn, 'Public-Private Partnership in the Netherlands', EPPPL, 2016, 46, 48;

- J M Hebly, M Klijn, 'Public-Private partnerships in the Netherlands' [2016] EPPPL;

- J M Sarmento, L Renneboog, Anatomy of public-private partnerships: their creation, financing, and renegotiations, ISSN, 2014;

- J Saparauskas, Z Turskis, 'Evaluation of Construction Sustainability by multiple criteria methods' [2006] Technological and Economic Development of Economy;

- J Shaoul, "A critical financial analysis of the Private Finance Initiative: selecting a financing method or allocating economic wealth?" [2005] Critical Perspectives on Accounting, 16(4), 441, 471;

- J Shaoul, A Stafford, P Stapleton, 'The Cost of Using Private Finance to Build, Finance and Operate Hospitals' [2008] Public Money and Management;

- J Wilson, 'Compulsory Competitive Tendering And Local Government Financial Services: An Analysis Of The Views Of Local Government Accountants In The North West Of England' [1999] Public Administration, Blackwell;

- J Yuan, M J Skibniewski, Q Li, L Zheng, 'Performance objectives selection model in public-private partnership projects based on the perspective of stakeholders' [2010] Journal of Management in Engineering;

- K Christian, W Julia, 'The Relevance of EC State Aid Control for PPP Infrastructure Funding' [2007] EPPPL; 
- K Krüger, "Non-economical "soft" and "green" considerations in public contract award procedures' [2002] Europarättslig tidskrift;

- Klijn, "Institutional and strategic barriers to public-private partnerships: an analysis of the Dutch case" [2003] Public Money \& Management, 23(3), 137, 146;

- L B Sagalyn, 'Public Private Development: Lessons from History, Research and Practice' [2007] Journal of the American Planning Association;

- L Bonechi, 'Offerta economicamente più vantaggiosa: la Corte ribadisce la legittimità dei criteri di valutazione di natura non economica' [2003] Diritto pubblico comparato ed europeo;

- L Hommen, M Rolfstam, 'Public Procurement and Innovation: Towards a Taxonomy' [2009] Journal of Public Procurement;

- L Lomas, 'Does the development of mass education necessarily mean the end of quality?' [2002] Quality in higher education;

- L Rubini, 'Brevi note a margine del caso PreussenElektra, ovvero come "prendere seriamente" le norme sugli aiuti di stato e la tutela dell'ambiente nel diritto comunitario' [2001] Diritto Comunitario e degli Scambi Internazionali;

- $\quad$ L Y Shen, A Platten, X Deng, 'Role of public-private partnerships to manage risks in public sector projects in Hong Kong' [2006] International Journal of project Management;

- L Y Tang, Q Shen, E W L Cheng, 'A review of Studies on Public-Private Partnerships Projects in the Construction Industry' [2010] International Journal of Project Management;

- L Zhou, R Keivani, E Kurul, 'Sustainability Performance Measurement Framework for PFI projects in the UK' [2013] Journal of Financial Management of Property and Construction;

- Li Bing, A Akintoye, P J Edwards, C Hardcastle, 'The Allocation of Risk in PPP/PFI Construction Projects in the UK' [2005] International Journal of Project Management;

- M Andrecka, 'Institutionalised Public-Private Partnership as a Mixed Contract under the Regime of the New Directive 2014/24/EU', [2014] 3 EPPPL;

- M Barzelay, F Cortazar, J C \& Cejudo, 'Research on Public Management Policy Change in the Latin America Region: A Conceptual Framework and Methodological Guide’ [2003] International Public Management Review;

- M Bleda, M Valente, 'Graded eco-labels: A demandoriented approach to reduce pollution' [2009] Technological Forecasting \& Social Change;

- M Bronckers, R Van der Vlies, 'The European Court's PreussenElektra Judgment: Tensions Between E.U. Principles and National Renewable Energy Initiatives' [2001] European Competition Law Review;

- M Burgi, B Brandmeier, 'Quality as an Interacting Award Criterion under Current and Future EU-Law' [2014] EPPPL;

- M Burnett, 'Beyond the New Public Procurement Directive - the Future for Public Private Partnerships' [2005] Eipascope;

- M Burnett, 'PPP contract management-Still in Need of More Attention?' [2013] EPPPL;

- M Burnett, 'The New European Directive on the Award of Concession Contracts, Promoting Value for Money in PPP Contracts?' [2014] EPPPL;

- M Burnett, 'The New Rules for Competitive Dialogue and Competitive Procedure with Negotiation in Directive 2014/24 - What Might They Mean for PPP?' [2015] EPPPL; 
- M Dischendorfer, 'The Rules on Award Criteria Under the EC Procurement Directives and the Effect of Using Unlawful Criteria: The EVN Case' [2004] PPLR;

- M E Comba, 'Selection and award criteria in Public Procurement Law' [2008] PPLR;

- M Lopez Escudero, 'Régimes nationaux d'aide à l'énergie verte face à libre circulation des marchandises dans l'Union européenne' [2014] Revue des affaires européennes;

- M Lottini, 'Appalti comunitari: sull'ammissibilità di criteri di aggiudicazione non prettamente economici' [2002] Il Foro amministrativo;

- M M Kumaraswamy, D A Morris, 'Build-Operate-transfer type procurement in Asian megaprojects' [2002] Journal of Construction Engineering and Management;

- M Martens, S De Margerie, 'The Link to the Subject-Matter of the Contract in Green and Social Procurement' [2013] EPPPL;

- M Nagelkerke, M Van Valkenburg, 'Lacking Partnership in PPP Projects', EPPPL, 2016, 346, 360;

- M Rossi, R Civitillo, 'Public-Private Partnerships: a general overview in Italy' [2014] 2nd World conference on Business, Economics and Management - WCBEM 2013, Procedia Social and Behavioural Sciences;

- M Sagoff, 'The rise and fall of ecological economics. A cautionary tale' [2012] Breakthrough Journal;

- M Spackman, 'Multi-Year Perspective in Budgeting and Public Investment Planning' [2002] draft paper, session III, OECD Global Forum on Sustainable Development;

- N C Frommelt, 'Better Buying Power and Incentives Public-Private Partnerships through Non-Monetary Incentives', Army Lawyer, 2017, 14, 23;

- N Pongsiri, 'Regulation and Public-Private Partnership' [2002] International Journal of Public Sector Managament;

- N Wang, 'Risk allocation in the operational stage of private finance initiative projects' [2011] Journal of Performance of Constructed Facilities;

- N Wang, K Wei, H Sun, 'Whole Life Project Management Approach to Sustainability' [2014] J. Manage. Eng.;

- N Wang, R Ding, M Radosavljevic, H Sun, 'Practicing Sustainability in PFI Project Management', [2011] Technology Management Conference, IEEE International;

- O E Williamson, "The organisation of work: a comparative institutional assessment" [1980] Journal of Economic Behaviour and Organisation, 1, 38;

- O H Petersen, 'Emerging Meta-Governance as a Regulation Framework for Public-private partnerships: an examination of the European Union's Approach' [2010] International Public Management Review;

- O Hart, 'Incomplete contracts and public ownership: remarks, and an application to publicprivate partnerships' [2003] Economic Journal;

- O Perera, B Morton, T Perfrement, 'Life Cycle Costing in Sustainable Public Procurement:

A Question of Value' [2009] IISD Paper, available at

- O Soloviov, 'Government Is Struggling to Streamline PPPs through Better Legislation: Many Issues Remain to Be Solved', EPPPL, 2016, 149, 153;

- P Bordalo Faustino, 'Award Criteria in the New EU Directive on Public Procurement' [2014] PPLR; 
- P Braun, 'Selection of Bidders and Contract Award Criteria: the Compatibility of Practice in PFI Procurement with European Law' [2001] PPLR;

- P Braun, 'Strict Compliance versus Commercial Reality: the Practical application of EC Public Procurement Law to the UK's Private Finance Initiative' [2003] ELJ;

- P Cerqueira Gomes, 'The Innovative Innovation Partnerships Under the 2014 Public Procurement Directive' [2014] PPLR;

- P D Rwelamila, P Fewings, C Henjewle, 'Addressing the Missing Link in PPP Projects: What Constitutes the Public?' [2014] Journal of Management in Engineering;

- P Ichino, La clausola sociale di garanzia del salario minimo negli appalti pubblici al vaglio della Corte di giustizia europea: il caso Bundesdruckerei' [2015] Rivista Italiana di Diritto del Lavoro;

- P Kunzlik, 'From suspect practice to market-based instrument: policy alignment and the evolution of EU law's approach to "green" public procurement' [2013] PPLR;

- P Kunzlik, "Making the Market Work for the Environment: Acceptance of (Some) "Green" Contract Award Criteria in Public Procurement' [2003] Journal of Environmental Law;

- P Lefèvre, 'Les considérations sociales et environnementales dans les marchés publics européens' [2000] Journal des tribunaux/droit européen;

- P Rwelamila, P Fewings, C Henjewele, 'Addressing the Missing Link in PPP Projects: What Constitutes the Public?' [2015] J Manage Eng;

- R A Frosch, N E Gallopoulos, 'Strategies for Manufacturing, Waste from one industrial process can serve as the raw materials for another, thereby reducing the impact of industry on the environment' [1989] Scientific American;

- R Ball, H Maryanne, D King, "The Private Finance Initiative in the UK" [2007] Public Management Review, 9(2), 289, 310;

- R Ball, M Heafey, D Kin, "The Private Finance Initiative in the UK" [2007] Public Management Review, 9(2), 289, 310;

- R Bickerstaff, 'Applying the EC rules on standards and specifications in public and utilities procurement' [1994] PPLR;

- R Caranta, 'Helping Public Procurement Go Green: The Role of International Organisations' [2013] EPPPL;

- R Caranta, 'La Corte di Giustizia definisce le condizioni di legittimità dei partenariati pubblico-privati' [2010] Giur. it.;

- R Craven, 'The EU's 2014 Concessions Directive' [2014] PPLR;

- R De Bondt, 'Spillovers and Innovative Activities' [1997] International Journal of Industrial Organization;

- R Garwood, 'Sustainability Lessons from Private Finance and Similar Private Initiatives', [2002] Information Paper, BRE;

- R Grießhammer, C Benoît, L C Dreyer, A Flysjö, 'Feasibility Study: Integration of Social Aspects into LCA' [2006] available at http://www.saiplatform.org/uploads/Library/UNEPSETACLifeCycleInitiativeTFonSocialIssues-FeasibilityStudy.pdf;

- R H Weber, 'Development promotion as a secondary policy in public procurement' [2009] PPLR;

- R Hamson, L Bird, 'Devolved Budgets in the Public Sector: A New Conceptual Framework for Consultancy Evaluation' [2008] Journal of Finance and Management in Public Services; 
- R Hrab, "Private delivery of public services: public private partnerships and contractingout" [2004] SSRN, available https://ssrn.com/abstract=694582;

- R Luciano, L Andriola, M D’Amico, 'Quando la Pubblica Amministrazione Acquista Verde' [2005] Ambiente e Sviluppo;

- R Osei-Kyei, A P C Chan, 'Review of Studies on the Critical Success Factors for PublicPrivate Partnership (PPP) Projects from 1990 to 2013' [2015] International Journal of Project Management;

- R Williams, 'The proposed Commission Draft Communication on the Environment and the impact of the Nord Pas-de-Calais Region case' [2001] PPLR;

- S Arrowsmith, 'Special Issue - The New EU Procurement Directive: Part I, Editors Note' [2014] PPLR;

- S Arrowsmith, 'The European Procurement Rules and Public-Private Partnerships: EU Policies in Conflict?' [2000] CML Rev;

- S Charveron, 'Competitive Dialogue threatens PFI' [2007] Construction Law;

- S H Linder, 'Coming to Terms with the Public-Private Partnerships, A Grammar of Multiple Meanings' [1999] American Behavioral Scientist;

- S Hodkinson, 'The Private Finance Initiative in English Council Housing Regeneration: a Privatisation too Far?' [2011] Housing Studies;

- S Izzo, 'La tutela dell'ambiente non é un valore assoluto' [2003] Diritto pubblico comparato ed europeo;

- S Ng, J M Wong, K Wong, 'A Public Private People Partnerships (P4) Process Framework for Infrastructure Development in Hong Kong' Department of Civil Engineering, The University of Hong Kong, available at

- S O Kahn-Freund, 'Legislation through Adjudication: the Legal Aspects of the Fair Wages Clauses and Recognised Conditions' [1948] Modern Law Review;

- S P Ho, 'Model for Financial renegotiation in Public-private partnerships projects and its policy implications: game theoretic view' [2006] Journal of Construction Engineering and Management;

- S P Ho, L Y Liu, "Analytical model for analyzing construction claims and opportunistic bidding" [2004] Journal of construction engineering and management, 130(1), 94, 104;

- S P Mullin, 'Public-Private Partnerships and State and Local Economic Development: Leveraging Private Investment' [2002] Reviews of Economic Development Literature and Practice;

- S Poli, 'National Schemes Supporting the Use of Electricity Produced from Renewable Energy Sources and the Community Legal Framework' [2002] Journal of Environmental Law;

- S R Norwood, N R Mansfield, 'Joint venture issues concerning European and Asian construction markets of the 1990's' [1999] International Journal of Project Management;

- S Robin-Olivier, 'Verdissement des marchés publics: des exigences environnementales, mais pas un écolabel particulier' [2013] Revue trimestrielle de droit européen;

- S Treumer, 'The Distinction between Selection and Award Criteria in EC Public Procurement Law: A Rule without Exception' [2009] PPLR;

- S Van Garsse, E Van den Broek, J Buyck, 'PPP Contracts: Amendments to PPP Projects Based on Experience in Flanders', EPPPL, 2016, 111, 118; 
- S Witjes, R Lozano, 'Towards a more Circular Economy: Proposing a framework linking sustainable public procurement and sustainable business models' [2016] Resources, Conservation and Recycling;

- T Curristine, Z Lonti, I Joumard, 'Improving Public Sector Efficiency: Challenges and Opportunities' [2007] OECD Journal on Budgeting;

- T De Lemos, L Almeida, M Betts, D Eaton, 'An Examination on the Sustainable Competitive Advantage of Private Finance Initiative Projects' [2003] Construction Innovation, Information, Process, Management;

- T E Swarr, 'Societal Life Cycle Assessment - Could You Repeat The Question?' [2009] International Journal Life Cycle Assessment;

- T Gliozzo, 'L'admissibilité d'un critère environnemental au regard de la réglementation communautaire des marhcés' [2004] L'actualité juridique; droit administratif;

- $\mathrm{T}$ Kotsonis, 'Commission $\mathrm{v}$ Netherlands (C-368/10): Environmental and fair-trade considerations in the context of a contract award procedure' [2012] PPLR;

- T Kotsonis, 'The 2014 Utilities Directive of the EU: Codification, Flexibilisation and Other Misdemeanours' [2014] PPLR;

- T Kotsonis, 'The Nature of Award Criteria and the Subsequent Stipulation of Weightings and Sub-criteria: Lianakis v Dimos Alexandroupolis (C-532/06)' [2008] PPLR;

- T Kuhn, 'Implications of the "Preussen Elektra" Judgment of the European Court of Justice on the Community Rules on State Aid and the Free Movement of Goods. Preliminary Ruling of 13 March 2001, Case C-379/98, Preussen Elektra v. Schleswag' [2001] Legal Issues of Economic Integration;

- T M Nisar, 'Implementation Constraints in Social Enterprise and Community Public-Private Partnerships' [2013] International Journal of Project Management, Elsevier, 638, 651;

- T Ysa, 'Governance forms in urban public-private partnerships' [2007] International Public Management Journal;

- V De Falco, 'L'utilizzo di fonti di energia rinnovabili come criterio di valutazione dell'offerta economicamente più vantaggiosa: la legge austriaca a confronto con l'ordinamento comunitario' [2004] Diritto pubblico comparato ed europeo;

- W Scharnhorst, 'Life Cycle Assessment in the Telecommunication Industry: A Review' [2008] International Journal of Life Cycle Assessment;

- X Q Zhang, 'Concessionaire selection: methods and criteria' [2004] Journal of Construction Engineering and Management;

- X Q Zhang, 'Improving concessionaire selection protocols in public-private partnered infrastructure projects' [2004] Journal of Construction Engineering and Management;

- X Q Zhang, M M Kumaraswamy, 'Hong Kong experience in managing BOT projects' [2001] Journal of Construction Engineering and Management;

- X Q Zhang, M M Kumaraswamy, W Zheng, E Palaneeswaran, 'Concessionaire selection for build-operate-transfer tunnel projects in Hong Kong' [2002] Journal of Construction Engineering and Management;

- Y L Huang, S P Chou, 'Valuation of the minimum revenue guarantee and the option to abandon in BOT infrastructure projects' [2006] Construction Management and Economics. 


\section{Reports and other types of publications}

- 10 Anni di Partenariato Pubblico Privato in Italia, Sintesi, Project Financing, Osservatorio Nazionale, Cresme Europa Servizi, 2011;

- 4Ps Review of Operational PFI and PPP projects, Local Government's project delivery specialist, 2005, available at https://www.bipsolutions.com/docstore/pdf/11980.pdf;

- A Schuurmans, Arno Fluitman, P Spiertz, J Broers, G Schweitzer, J Duijsens, DuboCalc: LCA tool for design of constructions in the ground, road and waterworks sector, available at http://www.irbnet.de/daten/iconda/CIB2921.pdf;

- Asian Development Bank, Inter-American Development Bank, World Bank Group, PublicPrivate Infrastructure Advisory Facility, Public-Private Partnerships Reference Guide, 2014, available at

https://ppp.worldbank.org/public-private-partnership/library/public-private-partnershipsreference-guide-version-20;

- Autorità per la Vigilanza sui Contratti Pubblici di Lavori Servizi e Forniture, L'affidamento dei contratti pubblici di importo inferiore alla soglia comunitaria mediante procedura negoziata, 2010, available at

http://arrow.dit.ie/cgi/viewcontent.cgi?article=1007\&context=futuresacrep;

- Autorità per la Vigilanza sui Contratti Pubblici di Lavori Servizi e Forniture, of January, 14, 2009, n. 1, Linee guida sulla finanza di progetto dopo l'entrata in vigore del cd. Terzo Correttivo, D. Lgs. 11 settembre 2008, n. 152;

- Barriers to Innovation in Public-Private Partnerships (PPP), Gunnigan, Eaton, Conference Papers School of Construction, Dublin Institute of Technology, 2008, available at http://arrow.dit.ie/cgi/viewcontent.cgi?article=1087\&context=beschreccon;

- Barts and the London NHS Trust, Sustainable Regeneration Program, 2006, available at http://www.apho.org.uk/resource/item.aspx?RID=92888;

- Best Value Statutory Guidance, Department for Communities and Local Government, 2011, available at

https://www.gov.uk/government/uploads/system/uploads/attachment_data/file/5945/197692 6.pdf;

- BRE, Profiting from Sustainability: Business and Sustainability, London, 2002;

- BREEAM, UK New Construction, Technical Manual, available at http://www.breeam.com/filelibrary/BREEAM\%20UK\%20NC\%202014\%20Resources/SD5 076_DRAFT_BREEAM_UK_New_Construction_2014_Technical_Manual_ISSUE_0.1.pdf ;

- C McCabe, "What is cost-utility analysis?" [2009], Hayward Medical Communications, available at http://www.whatisseries.co.uk/what-is-cost-utility-analysis/;

- C Phillips, What is cost effectiveness?, Health Economics, 2009, available at http://www.bandolier.org.uk/painres/download/whatis/Cost-effect.pdf;

- Cambridge Economic Policy Associates Ltd, Report on Public-Private Partnerships in Scotland, Evaluation of Performance, 2005, available at http://www.gov.scot/Resource/Doc/917/0011854.pdf; 
- Capital Hospitals and Barts and the Royal London, Transforming London's historic hospital, Skanska, available at http://skanska-sustainability-case-studies.com/index.php/latest-casestudies/item/128-barts-and-the-london-hospitals-uk;

- CBI, Building on Success: the Way forward for PFI, 2007, available at http://infrastructureaustralia.gov.au/policypublications/publications/files/Bldg_on_success_The_way_forward_4_PFI_UK_CBI.pdf;

- Choosing our Future: Scotland's Sustainable Development Strategy, 2005, available at http://www.gov.scot/resource/doc/47121/0020703.pdf;

- CIPE, Revisione delle Linee Guida per le Politiche e Misure Nazionali di Riduzione delle Emissioni dei Gas Serra (Legge 120/2002), available at

http://www.minambiente.it/sites/default/files/archivio/allegati/vari/deliberaCIPE_19_12_02. pdf;

- D Eamonn, Butler, M P Allan Stewart, Seize the Initiative, Adam Smith Institute, 1996;

- D Ehrhardt, T Erwin, Avoiding Customer and Taxpayer Bailouts in Private Infrastructure Projects, World Bank Policy Research Working Paper 3274, 2004;

- D Katz, New Zealand Treasury Financing Infrastructure Projects: Public Private Partnerships (PPPs), Policy Perspectives Paper 06/02, 2006, 7;

- Department for Environment, Food and Rural Affairs, 'Greening Government Commitments: operations and procurement', 2011, available at https://www.gov.uk/government/publications/greening-government-commitmentsoperations-and-procurement;

- Department for Environment, Food and Rural Affairs, Mainstreaming Sustainable Development: the government's vision and what this means in practice', 2011, available at https://www.gov.uk/government/publications/mainstreaming-sustainable-development-thegovernment-s-vision-and-what-this-means-in-practice;

- Department of Treasury and Finance, Investment Evaluation: Policy and Guidelines, 1996, State of Victoria, Australia;

- Development of an Embedded Carbon Emissions Indicator, Producing a Time Series of Input-Output Tables and Embedded Carbon Dioxide Emissions for the UK by Using a MRIO Data Optimisation System, Final Report to the Department for Environment, Food and Rural Affairs, 2008;

- Dipartimento per la Programmazione e il Coordinamento della Politica Economica, Unità Tecnica Finanza di Progetto, Partenariato pubblico-privato in Italia, Stato dell'arte, futuro, proposte, 2010;

- Documento di Economia e Finanza 2014, Relazione del Ministero dell'Ambiente e della tutela del territorio e del mare sullo stato di attuazione degli impegni per la riduzione delle emissioni di gas ad effetto serra, L. n. 39/2011, art. 2, co. 9., available at http://ec.europa.eu/europe2020/pdf/csr2014/ghg2014_italy_it.pdf;

- Drawbacks of PPP, Toolkit for Public - Private Partnerships in roads \& Highways, PublicPrivate Infrastructure Advisory Facility (PPIAF), 2009;

- DuboCalc: LCA tool for design of constructions in the ground, road and waterworks sector, A Schuurmans, A Fluitman, P Spiertz, J Broers, G Schweitzer, J Duijsens, available at http://www.irbnet.de/daten/iconda/CIB2921.pdf; 
- Eco-innovation achieved through advanced policy and procurement mechanisms, Innovation seeds, available at

http://www.innovationseeds.eu/Policy-Library/Core-Articles/Eco-Innovation-AchievedThrough-Advanced-Policy-And-Procurement-Mechanisms.kl;

- Economic and Financial Report, Public-Private Partnerships in Europe before and during the recent financial crisis, A Kappeler, M Nemoz, European Investment Bank, 2010, available at http://www.eib.org/epec/resources/efr_epec_ppp_report1.pdf;

- European Commission, Evaluation Report: Impact and Effectiveness of EU Public Procurement Legislation (Commission Staff Working Paper) SEC (2011) 853 final;

- European Investment Bank Evaluation Report, Operations Evaluation Department, Evaluation of PPP projects financed by the EIB - Synthesis Report March, 2005, available at http://www.eib.org/attachments/ev/ev_ppp_en.pdf;

- European Investment Bank, The Non-financial Benefits of PPPs: a Review of Concepts and Methodology, European PPP Expertise Centre, 2001, available at http://www.eib.org/epec/resources/epec-non-financial-benefits-of-ppps-public.pdf;

- Eurostat Treatment of Public-Private Partnerships Purposes, Methodology and Recent Trends, European PPP Expertise Centre, European Investment Bank, 2010, available at http://www.eib.org/epec/resources/epec-eurostat-statistical-treatment-of-ppps.pdf;

- Evaluating the Operation of PFI in Road and Hospital Projects, P Edwards, J Shaoul, A Stafford, L Arblaster, ACCA Research Report No 84, London, 2004;

- F Blanc-Brude, H Goldsmith, T Valila, Ex-Ante Construction Costs in the European Road Sector: A Comparison of Public-Private Partnerships and Traditional Public Procurement, European Investment Bank, European and Financial Report, 2006/01, available at http://www.eib.org/attachments/efs/efr_2006_v01_en.pdf;

- G Allen, The Private Finance Initiative (PFI), House of Commons Library Research Paper 01/117, 2001;

- G Van Herpen, Public Private Partnerships, the advantages and disadvantages examined, Dutch Ministry of Transport, Public Works and Water Management, Directorate-General of Public Works and Water Management, Transport Research Centre, 2002;

- Good Practice in Socially Responsible Public Procurement, Approaches to Verification from Across Europe, The Landmark Project, Moving Towards Socially Responsible Procurement, 2012, available at

http://www.landmark-project.eu/fileadmin/files/en/latest-achievements/LANDMARKgood_practices_FINAL.pdf;

- Government Procurement Service annual report and accounts 2013 to 2014 available at https://www.gov.uk/government/publications/government-procurement-service-annualreport-and-accounts-2013-to-2014;

- Guidebook on Public-Private Partnership in Infrastructure, Economic and Social Commission for Asia and the Pacific, 2011, available at http://www.unescap.org/sites/default/files/ppp_guidebook.pdf;

- Harnessing the Power of Public-Private Partnerships: the Role of Hybrid Financing Strategies in Sustainable Development, International Institute for Sustainable Development, Colverson, Perera, available at http://www.iisd.org/pdf/2012/harnessing_ppp.pdf; 
- HEATCO, Developing Harmonized European Approaches for Transport Costing and Project Assessment, Proposal for Harmonized Guidelines, 2006, available at http://heatco.ier.uni-stuttgart.de/HEATCO_D5.pdf;

- HM Treasury, Modern Government: Modern Procurement, 1999;

- HM Treasury, PFI: Meeting the Investment Challenge, 2003, Providing the Government's policy on the use of PFI, available at

http://webarchive.nationalarchives.gov.uk/20130129110402/http:/www.hmtreasury.gov.uk/media/F/7/PFI_604a.pdf;

- HM Treasury, Private Finance Initiative, Seventeenth Report, 2011, available at http://www.publications.parliament.uk/pa/cm201012/cmselect/cmtreasy/1146/1146vw.pdf

- HM Treasury, The Green Book, Appraisal and Evaluation in Central Government, 2003, available at

https://www.gov.uk/government/uploads/system/uploads/attachment_data/file/220541/green _book_complete.pdf;

- HM Treasury, UK Private Finance Initiative Projects: Summary Data as at March 2012, available at

https://www.gov.uk/government/uploads/system/uploads/attachment_data/file/207369/sum mary_document_pfi_data_march_2012.pdf;

- HM Treasury, Value for money and the valuation of public sector assets, 2008, available at https://www.gov.uk/government/uploads/system/uploads/attachment_data/file/191488/Gree n_book_supplementary_guidance_asset_valuation.pdf;

- HM Treasury, Value for Money Assessment Guidance, 2006, available at https://www.gov.uk/government/uploads/system/uploads/attachment_data/file/252858/vfm_ assessmentguidance061006opt.pdf;

- HM Treasury, Value for Money Assessment Guidance, 2008, available at http://webarchive.nationalarchives.gov.uk/20130129110402/http://www.hmtreasury.gov.uk/d/vfm_assessmentguidance061006opt.pdf;

- House of Lords, Select Committee on Economic Affairs, 1st report of Session 2009-10, Private Finance Projects and off balance sheet debt, 2010, available at http://www.publications.parliament.uk/pa/ld200910/ldselect/ldeconaf/63/63i.pdf;

- Innovation in Governance and Public Administration: Replicating What Works, Department of Economic and Social Affairs, United Nations Publications, 2006, available at http://unpan1.un.org/intradoc/groups/public/documents/UN/UNPAN021963.pdf;

- J Hill, J Collins, PFI: meeting the Sustainability challenge, Green Alliance, London, 2004, available at http://www.greenalliance.org.uk/resources/PFI\%20Meeting\%20the\%20sustainability\%20challenge.pdf;

- J L Guasch, Renegotiation of concession contracts in Latin America, World Bank Publications, 2003;

- KPMG in collaboration with University College London, Operating Healthcare Infrastructure: Analysing the Evidence, 2010, available at http://www.kpmg.com/TW/zh/IssuesAndInsights/Documents/IGH/Global-infrastructurespotlight-Benchmarking-healthcare.pdf; 
- KPMG, Infrastructure Spotlight Report, PFI in school building - does it influence educational outcomes?, 2009, available at http://www.kpmg.eu/docs/20100120_PFI-inschool-building.pdf;

- L Zhou, E Kurul, R Keivani, Sustainability Evaluation in the PFI industry: Analysis of the questionnaire survey. Proceedings of Symposium on 'Sustainability and Value through Construction Procurement', Manchester, 2006;

- L Zhou, E Kurul, R Keivani, The Economic Benefits of Sustainable PFI Project: A case study of Newport Southern Distributor Road, Proceedings of the 2008 World Sustainable Building Conference, Melbourne, Australia, 2008;

- La nuova finanza di progetto nel Codice dei contratti, UTPF, M Ricchi, 2009;

- Linee guida per l'affidamento delle concessioni di lavori pubblici e di servizi ai sensi dell'articolo 153 del decreto legislativo 12 aprile 2006, n. 163, Autorità Nazionale Anticorruzione Vigilanza Contratti Pubblici, Bozza di Determinazione, available at http://www.anticorruzione.it/portal/rest/jcr/repository/collaboration/Digital\%20Assets/anacd ocs/Attivita/ConsultazioniOnline/20150108/Cons.PF.03.0315.pdf;

- M Walther, Partnering Capacity in White-Collar Public-private Partnerships, 2009, University of St. Gallen, available at http://www1.unisg.ch/www/edis.nsf/SysLkpByIdentifier/3580/\$FILE/dis3580.pdf;

- Making the Most of Markets: the Role of IFIs, N Stern, H P Lankers, International Financial Institutions in the $21^{\text {st }}$ century, European Investment Bank Papers, 1998, available at http://www.eib.org/attachments/efs/eibpapers/eibpapers_1998_v03_n02_en.pdf;

- Meeting the Infrastructure Challenge with Public-Private Partnerships: Bridging the Gap, M Airoldi, J Chua, P Gerbet et all, The Boston Consulting Group, 2013, available at http://www.bcg.de/documents/file128534.pdf;

- Mission d'appui aux partenariats public-privé, Typologie des PPP: Comparaison Juridique et Terminologique des PPP dans les Conceptions Française et Anglo-saxonne, 2013, available at http://www.economie.gouv.fr/files/files/directions_services/ppp/glossaire_fr_en.pdf;

- NAO, Department of Health, Innovation in the NHS: Local Improvement Finance Trusts, 2005, available at https://www.nao.org.uk/wp-content/uploads/2005/05/050628.pdf;

- NAO, Performance of PFI Construction, 2009, available at https://www.nao.org.uk/wpcontent/uploads/2009/10/2009_performance_pfi_construction.pdf;

- NAO, PFI in Housing, Project Details, 2010, available at https://www.nao.org.uk/wpcontent/uploads/2010/06/101171.pdf;

- NAO, PFI: Construction Performance, 2003, available at https://www.nao.org.uk/wpcontent/uploads/2003/02/0203371.pdf;

- NAO, Sustainable Procurement in Government, 2013, available at https://www.nao.org.uk/wpcontent/uploads/2013/03/EAC_briefing_sustainable_procurement_government.pdf;

- National Institute for Health and Clinical Excellence, Guide to the methods of technology appraisal, 2013, available at https://www.nice.org.uk/process/pmg9/chapter/foreword;

- National Institute of Standards and Technology, S Fuller, Life Cycle Cost Analysis for Sustainable Buildings, available at https://www.wbdg.org/resources/lcca.php;

- OECD, Country Case, Green Public Procurement in the Netherlands, Public Procurement Toolbox, 2016, available at 
https://www.oecd.org/governance/procurement/toolbox/search/green-public-procurementnetherlands.pdf;

- OECD, Country Case, Green Public Procurement in the Netherlands, Public Procurement Toolbox, 2016, available at https://www.oecd.org/governance/procurement/toolbox/search/green-public-procurementnetherlands.pdf;

- OECD, Public - Private partnerships, in pursuit of risk sharing and value for money, 2008;

- OECD, Recommendation of the Council on Principles for Public Governance of PublicPrivate Partnerships, 2012, available at https://www.oecd.org/governance/budgeting/PPPRecommendation.pdf;

- Office of the Deputy Prime Minister, Private Finance Initiative Schemes for HRA/NonHRA Housing, Guidance for Authorities Making Proposals, Private Finance Initiative, Creating Sustainable Communities, 2005, London, available at https://www.gov.uk/government/uploads/system/uploads/attachment_data/file/7874/142805. pdf;

- One Future Different Paths - The UK's shared framework for sustainable development, 2005, available at http://www.sd-commission.org.uk/publications.php?id=215;

- Performance of PFI Construction, Report of the National Audit Office, 2009, available at https://www.nao.org.uk/wpcontent/uploads/2009/10/2009_performance_pfi_construction.pdf;

- PFI Projects seek Partners, N Timmins, Financial Times, 2009, available at https://www.ft.com/content/efe3c052-01e2-11de-8199-000077b07658;

- PFI: Construction Performance, Report by the controller and auditor general HC 371, 2003, available at https://www.nao.org.uk/wp-content/uploads/2003/02/0203371es.pdf;

- PPPIRC, World Bank guidelines available at http://ppp.worldbank.org/public-privatepartnership/overview/practical-tools/procurement-bidding/standardized-guidelines;

- Procura+, European Sustainable Procurement network, The Procura+Manual: A Guide to Implementing Sustainable Procurement, 2016, available at http://www.procuraplus.org/fileadmin/user_upload/Manual/Procuraplus_Manual_Third_Edi tion.pdf;

- Project 2002, Full Business Case, available at http://www.gov.scot/resource/doc/923/0050881.pdf;

- Proposal for a Directive of the European Parliament and of the Council on Public Procurement, Brussels, 20.12.2011, COM (2011) 896 final, 2011/0438 (COD) 60;

- Public-Private Partnerships and Sustainability, Principles Guiding Legislation and Current Practice, B Ryan, 2004, available at http://arrow.dit.ie/cgi/viewcontent.cgi?article=1007\&context=futuresacrep;

- Public-Private Partnerships: the Government's Approach, 2000;

- Quality Assurance and the Development of Course Programs. Papers on Higher Education, Regional University Network on Governance and Management of Higher Education in South East Europe, C Campbell, C Rozsnyai, Bucharest, UNESCO, 2002, available at http://unesdoc.unesco.org/images/0012/001295/129526eo.pdf;

- R Webb, B Pulle, Public Private Partnerships: an Introduction, Research Paper no. 1, Parliamentary Library, Commonwealth of Australia, 2003; 
- Report on the proposal for a Directive of the European Parliament and of the Council on public procurement of January 11, 2013, European Parliament's Committee on the Internal Market and consumer Protection;

- Report on the Public Consultation on the Green Paper on Public-Private Partnerships and Community Law on Public Contracts and Concessions, Commission Staff Working Paper, SEC (2005) 629;

- Residenza Sociale Sharing Ivrea 24, Programma di riqualificazione urbana, available at http://www.unioncamere.gov.it/P42A2186C189S123/Il-Partenariato-pubblico-privato-e-1edilizia-sostenibile-in-Italia-nel-2013.htm;

- Rijkswaterstaat, GPP 2020, Procurement for a low carbon economy, Construction of a lowcarbon motorway exit, available at ec.europa.eu/environment/gpp/pdf/news_alert/Issue36_Case_Study78_Rijkswaterstaat.pdf;

- Rijkswaterstaat, GPP In practice, Using LCA and CO2 performance to assess bidders, Issue n. 36, November 2013, available at http://ec.europa.eu/environment/gpp/pdf/news_alert/Issue36_Case_Study78_Rijkswaterstaat .pdf;

- Rijkswaterstaat, Sustainable procurement using DuboCalc and the CO2 performance ladder, 2015, available at http://www.gpp2020.eu/fileadmin/files/Training_materials/Training_reports_photos_etc/Sus tainable-procurement-using-DuboCalc-and-the-CO2-performance-ladder_lr....pdf;

- SEAD Initiative, US Department of Energy, Energy-Efficient Public Procurement: Best Practice in Program Delivery, 2013;

- Securing the Future: the UK sustainable Development Strategy, 2005, available at https://sustainabledevelopment.un.org/content/documents/1408uk.pdf;

- Skanska, Barts and the London Hospital, UK, Aspects of Sustainability, Case Study 65, 2010, available at http://www.businessperformance.org/sites/default/files/65_Barts_v001.pdf;

- SMEs' Access to Public Procurement Markets and Aggregation of Demand, EU G W Thomassen et all, study prepared for the European Commission by PwC, ICF GHK and Ecorys, 2014, available at

http://ec.europa.eu/internal_market/publicprocurement/docs/modernising_rules/smesaccess-and-aggregation-of-demand_en.pdf;

- Standard and Poor's, Infrastructure finance, The Anatomy of Construction Risk: Lessons from a Millennium of PPP Experience, 2007, available at http://www.robbain.com/The\%20Anatomy\%200f\%20Construction\%20Risk.pdf;

- Standardisation of PFI Contracts, available at http://webarchive.nationalarchives.gov.uk/20130129110402/http://www.hmtreasury.gov.uk/d/pfi_sopc4pu101_210307.pdf;

- Strategic Use of Public Procurement in Europe, W Kahlenborn, C Moser, J Frijdal, M Essig, Final Report to the European Commission, PPRC, Aldelphi, Belmont, MARKT/2010/02/C, 2011, available at http://ec.europa.eu/internal_market/publicprocurement/docs/modernising_rules/strategicuse-public-procurement-europe_en.pdf; 
- Sustainable Development in a Dynamic World: Transforming Institutions, Growth and Quality of Life, World Development Report 2003, co-publication of the World Bank and Oxford University Press, 2003;

- Sustainable Development Indicators in Your Pocket, 2009, available at https://www.gov.uk/government/uploads/system/uploads/attachment_data/file/69414/pb132 65-sdiyp-2009-a9-090821.pdf;

- Sustainable Development Unit, Case Study, Energy Engagement, Barts and the London NHS Trust, 2013, available at http://greenhospitals.net/wp-content/uploads/2012/03/EnergyBarts-UK.pdf;

- Sustainable Public Procurement in EU Member States: Overview of Government Initiatives and Selected Cases, Final Report to the EU High-Level Group on CSR, R Steurer, G Berger, A Konrad, A Martinuzzi, Research Institute for Managing Sustainability, Vienna University of Economics and Business Administration, 2007, available at

http://sustainability.eu/pdf/csr/policies/Sustainable\%20Public\%20Procurement\%20in\%20E U\%20Member\%20States_Final\%20Report.pdf;

- The EU explained, Europe 2020: Europe's growth strategy, Growing to a sustainable and job-rich future, 2012, available at http://ec.europa.eu/europe2020/pdf/europe_2020_explained.pdf.;

- The Foundations of the Italian Action Plan on the United Nations 'Guiding Principles on Business and Human Rights', available at http://www.mit.gov.it/mit/mop_all.php?p_id=18077;

- The Irish Environmental Protection Agency, Green Procurement Guidance for the Public Sector, 2014, available at http://greenbusiness.ie/wpcontent/uploads/2014/09/GreenProcurementGuidanceforPublicSector-web.pdf;

- The Millennium Development Goals, 2015, available at http://www.un.org/millenniumgoals/2015_MDG_Report/pdf/MDG\%202015\%20rev\%20(Ju ly\%201).pdf.;

- The Non-Financial Benefits of PPPs, A Review of Concepts and Methodology, European PPP Expertise Centre, European Investment Bank, 2011, available at http://www.eib.org/epec/resources/epec-non-financial-benefits-of-ppps-public.pdf;

- The Private Finance Initiative for Housing Revenue Account Housing, The Pathfinder Schemes Baseline Report, Communities and Local Government, 2008, available at https://www.thenbs.com/PublicationIndex/documents/details?Pub=DCLG\&DocID=287294;

- The Public Contracts Regulations 2015, Guidance on Awarding Contracts, Crown Commercial Service, available at https://www.gov.uk/government/uploads/system/uploads/attachment_data/file/417934/Guid ance_on_Awarding_Contracts.pdf;

- The Public Contracts Regulations 2015, Unravelling the key changes, Eversheds, available at

http://www.eversheds.com/documents/sectors/tmt/The-Public-Contracts-Regulations-2015Unravelling-the-key-changes.pdf;

- The Sustainability Imperative, New insights on Consumer Expectations, Nielsen, 2015, available at 
http://www.nielsen.com/content/dam/nielsenglobal/dk/docs/global-sustainability-report-oct2015.pdf;

- The uptake of green public procurement in the EU27, submitted to the European Commission, DG Environment and prepared by the Centre for European Policy Studies, 2012, available at http://ec.europa.eu/environment/gpp/pdf/CEPS-CoE-GPP\%20MAIN\%20REPORT.pdf;

- The World Bank, Procurement Policy Review, Feedback Summary, 2012, available at https://consultations.worldbank.org/Data/hub/files/meetings/HagueFeedbackSummary.pdf;

- The World Bank, The Role and Impact of Public-Private Partnerships in Education, 2009, available at http://www.ungei.org/resources/files/Role_Impact_PPP_Education.pdf;

- Theorizing Public-Private Partnership Success: A Market-Based Alternative to Government? G Hodge, C Greve, paper for the Public Management Research Conference at Syracuse University, 2-4 June 2011, Themed Panel on 'Market-Based Alternatives to Government', available at

http://openarchive.cbs.dk/bitstream/handle/10398/8573/Greve_2011_c.pdf?sequence=1;

- Time to Measure Value Creation!, Whitepaper, HEC, EcoVadis, Sustainable Procurement Barometer, 2013, available at

https://www.atkearney.de/documents/856314/4303900/HEC_AT+Kearney_EcoVadis_Susta inable+Procurement+Barometer+2013.pdf/8b1e9a61-52e3-4f1f-8e77-e0f3c21757e9;

- Treasury Taskforce, Partnerships for Prosperity, The Private Finance Initiative, 1997;

- UK's Local government sustainable procurement strategy, 2007, available at http://www.local.gov.uk/publications/-/journal_content/56/10180/3372545/PUBLICATION;

- UN Documents, Gathering a body of global agreements, Our Common Future, From One Earth to One World, available at http://www.un-documents.net/ocf-ov.htm;

- Understanding the Private Finance Initiative: the school governor's essential guide to PFI, D Rowland, A Pollock, UNISON, 2002, available at http://www.allysonpollock.com/wpcontent/uploads/2013/04/UNISON_2002_Pollock_PFISchoolGovernors.pdf;

- Unioncamere, Camere di Commercio d'Italia, Cresme Europa Servizi, 'Il partenariato pubblico privato e l'edilizia sostenibile in Italia nel 2013', available at http://www.unioncamere.gov.it/P42A2186C189S123/Il-Partenariato-pubblico-privato-e-1edilizia-sostenibile-in-Italia-nel-2013.htm;

- Unità Tecnica Finanza di Progetto, Partenariato Pubblico-Privato per la realizzazione di opere pubbliche: impatto sulla contabilità nazionale e sul debito pubblico, Roma, 2001;

- United Kingdom Treasury - Standardisation of PF2 Contracts, available at https://www.gov.uk/government/uploads/system/uploads/attachment_data/file/221556/infras tructure_standardisation_of_contracts_051212.pdf;

- United Nations Development Programme (UNDP), What are Public-Private Partnerships, 2005, available at http://pppue.undp.org/;

- United Nations Economic Commission for Europe, Guidebook on Promoting Good Governance in Public-Private Partnerships, New York and Geneva, 2008, available at https://www.unece.org/fileadmin/DAM/ceci/publications/ppp.pdf;

- United Nations General Assembly, The Road to Dignity by 2030: Ending Poverty, Transforming all lives and Protecting the Planet - Synthesis Report of the Secretary General on the Post-2015 Sustainable Development Agenda, 2014, available at 
http://www.un.org/disabilities/documents/reports/SG_Synthesis_Report_Road_to_Dignity_ by_2030.pdf;

- University of Melbourne, National PPP Forum, Benchmarking Study, Phase II, Report on the Performance of PPP projects in Australia when compared with a representative sample of traditionally procured infrastructure projects, 2008, available at http://infrastructureaustralia.gov.au/policypublications/publications/files/PC_Submission_Attachment_K.pdf;

- Value For Money Studies in Higher Education, J Erlendsson, 2002, available at https://notendur.hi.is// joner/eaps/wh_vfmhe.htm;

- W Kahlenborn, C Moser, J Frijdal, M Essig, Strategic use of Public Procurement in Europe - Final Report to the European Commission MARKT/2010/02C, 2010, available at http://ec.europa.eu/internal_market/publicprocurement/docs/modernising_rules/strategicuse-public-procurement-europe_en.pdf;

- What Makes Public-Private Partnerships Work? An Economic Analysis, J Bensaid, F Marty, Prisme, n. 27, Cournot Centre, 2014, available at http://www.osservatorioappalti.unitn.it/content.jsp?id=31;

- White Paper, A Better Quality of Life - a Strategy for Sustainable Development, 1999, available at https://www.publications.parliament.uk/pa/cm200102/cmselect/cmenvaud/824/824.pdf;

- Working document on a Proposal for a Directive of the European Parliament and of the Council on public procurement, from the European Parliament's Committee on the Internal Market and Consumer Protection of February 23, 2012;

- World Economic Forum, Global Agenda Council on Infrastructure 2012-2014, available at https://www.weforum.org/reports/global-agenda-council-infrastructure-2012-2014/;

- WRAP, Recycling Demolition Arisings at Barts and the London Hospital, WAS006-002, Demolition Exemplar Case Study, 2007, available at http://www.wrap.org.uk/sites/files/wrap/Barts\%20and\%20The\%20London\%20Report\%20f ull\%20case\%20study.pdf;

\section{EU soft law}

- Buying Green! - A Handbook on Green Public Procurement, 2016, available at http://ec.europa.eu/environment/gpp/pdf/Buying-Green-Handbook-3rd-Edition.pdf;

- Buying Social, A Guide to Taking Account of Social Considerations in Public Procurement, European Commission Directorate-General for Employment, Social Affairs and Equal Opportunities, 2010;

- Commission Communication of 15 May 2001, 'A Sustainable Europe for a Better World: A European Union Strategy for Sustainable Development' Commission proposal to the Gothenburg European Council, COM/2001/264 final;

- Commission Communication of 22 October 2007 'Progress Report on the Sustainable Development Strategy 2007' COM/2007/642 final - not published in the Official Journal; 
- Commission Communication of 9 February 2005, 'The 2005 Review of the EU Sustainable Development Strategy: Initial Stocktaking and Future Orientations’ COM/2005/37 final not published in the Official Journal;

- Commission Interpretative Communication on Concessions under Community Law, OJ C 121 ;

- Commission interpretative communication on the application of Community law on Public Procurement and Concessions to institutionalized PPP (IPPP) [2008/C 91/02 - Official Journal C 91 of 12.4.2008];

- Commission Interpretative Communication on the application of Community law on Public Procurement and Concessions to Institutionalised Public-Private Partnerships (IPPP), COM/2007/6661 final;

- Communication from the Commission to the Council and the European Parliament, Draft Declaration on Guiding Principles for Sustainable Development, COM/2005/218, final;

- Communication from the Commission to the Council and the European Parliament on the Review of the Sustainable Development Strategy, A Platform for Action, COM/2005/658, final;

- Communication from the Commission to the European Parliament, the Council, the European Economic and Social Committee and the Committee of the Regions Closing the loop - An EU action plan for the Circular Economy COM/2015/0614 final;

- Communication from the Commission to the European Parliament, the Council, the European Economic and Social Committee and the Committee of the Regions Public procurement for a better environment COM/2008/0400 final;

- Communication from the Commission to the European Parliament, the Council, the Economic and Social Committee and the Committee of the Regions, COM/2002/82 final;

- Communication from the Commission to the European Parliament, the Council, the European Economic and Social Committee and the Committee of the Regions Mainstreaming sustainable development into EU policies: 2009 Review of the European Union Strategy for Sustainable Development COM/2009/0400 final;

- Communication from the Commission to the European Parliament, the Council, the European Economic and Social Committee and the Committee of the Regions, Rio+20: Towards the Green Economy and Better Governance, COM/2011/363 final;

- Communication from the Commission to the European Parliament, the Council, the European Economic and Social Committee and the Committee of the Regions, Taking Stock of the Europe 2020 Strategy for Smart, Sustainable and Inclusive Growth, COM/2014/130 final;

- Communication from the Commission to the European Parliament, the Council, the European Economic and Social Committee and the Committee of the Regions, 'Mobilizing private and public investment for recovery and long-term structural change: developing Public Private Partnerships', COM/2009/615 final;

- Communication from the Commission to the European parliament, the council, the European economic and social committee and the committee of the regions on PublicPrivate Partnerships and Community Law on Public Procurement and Concessions, COM /2005/569 final; 
- Communication from the Commission to the European Parliament, the Council, the European Economic and Social Committee and the Committee of the Regions on the Sustainable Consumption and Production and Sustainable Industrial Policy Action Plan, COM/2008/397 final;

- Communication from the Commission, Europe 2020, A strategy for smart, sustainable and inclusive growth, European Commission, COM/2010/2020 final;

- European Commission, Buying Social: A Guide to Taking Account of Social Considerations in Public Procurement, Brussels, Belgium, Directorate General for Employment, Social Affairs and Inclusion, 2010;

- European Commission, Guide to Cost-Benefit Analysis of Infrastructure Projects, Structural Funds, Cohesion Fund and Instrument for Pre-Accession, Directorate General Regional Policy, 2008;

- European Commission, Guidelines for Successful Public-Private Partnerships, 2003, available at http://ec.europa.eu/regional_policy/sources/docgener/guides/ppp_en.pdf;

- European Parliament Resolution on Public-Private Partnerships and Community law on Public Procurement and Concessions (2006/2043(INI));

- Green Paper on Public-Private Partnerships and Community law on Public Contracts and Concessions, COM/2004/327 final;

- Green Paper on the Modernisation of EU Public Procurement Policy Towards a More Efficient European Procurement Market, COM/2011/15 final;

- House of Commons Treasury Committee, Private Finance Initiative, Seventeenth Report of Session 2010-12, available at

http://ec.europa.eu/internal_market/publicprocurement/docs/modernising_rules/executivesummary_en.pdf;

- Interpretative communication of the Commission on the Community law applicable to public procurement and the possibilities for integrating social considerations into public procurement COM/2001/0566 final;

New EU-procurement rules to ensure better quality and value for money, European Parliament press release, 2014, available at http://www.europarl.europa.eu/news/en/newsroom/20140110IPR32386/New-EU-procurement-rules-to-ensure-better-quality-and-valuefor-money;

- Non-paper prepared by the Commission services (DG Internal Market) on Cluster 2 (Strategic use of public procurement) of January 20, 2012;

- Opinion of the European Economic and Social Committee on the 'Communication from the Commission to the European Parliament, the Council, the European Economic and Social Committee and the Committee of the Regions: Single Market Act - Twelve levers to boost growth and strengthen confidence - "Working together to create new growth" COM/2011/ 206 final (2012/C 24/22);

- Proposal for a Directive of the European Parliament and of the Council on Public Procurement, COM/2011/896 final;

- Sustainable development indicators to monitor the implementation of the EU sustainable development strategy [SEC (2005) 161 - not published in the Official Journal]. 
Valorization addendum

\section{WHAT IS THE SOCIETAL AND ECONOMIC RELEVANCE OF THIS THESIS?}

The research questions addressed by this thesis are the following. Can PPPs be considered as public services and infrastructure delivery models actually capable of promoting also sustainable development goals through the generation of socio-environmental benefits? Which are the spaces for sustainable development concerns that can be located within PPPs' structures according to EU public contracts and concessions law? Which are the spaces for sustainable development considerations that can be located within PPP schemes according to public contracts and concessions laws of the Members States studied in this thesis? Through which means (i.e. tender and contractual strategies) public and private actors may actually integrate sustainability concerns within PPPs' structures and, therefore, deliver also socio-environmental benefits?

Therefore, the focus of this thesis lies on the study of the scope for sustainable development considerations within PPPs according to EU and national public contracts and concessions laws of the considered Members States. Moreover, this thesis aims at investigating the concrete strategies through which PPPs can embed sustainability considerations within their structure and, thus, generate socio-environmental benefits fostering sustainable development objectives.

The societal and economic relevance of this thesis follows primarily from the circumstance that its research questions relate to a pressing current-day challenge in the field of public services and infrastructure delivery: the need to boost economic growth and the functioning of the Internal Market along with the other equally important goals of socio-environmental sustainability. The thesis has established that the applicable public procurement regime as well as the inherent PPPs' features and mechanisms indeed allow public and private actors to shape PPPs upon both economic and sustainable demands. PPPs are capable of effectively balancing price, cost, risk, quality and performance with on-going assets' improvements. Moreover, PPPs create a favorable environment for innovation and sustainability. This PPP ability constituted an important justification to further investigate the tender and contractual strategies that can actually be used to embed socioenvironmental concerns within their structures and, thus, to promote sustainable development.

A second comment on the societal and economic relevance of this thesis relates to the legal basis of sustainable development. Article 3 of the TEU specifically foresees that the Union should work for its realization in the context of Europe. Therefore, the principle of sustainable development must guide Members States in the definition and implementation of the Union's policies and activities. This shared legal basis is directly connected with the EU's ambition of achieving and promoting the functioning Internal Market within the EU (Article 3 TEU; Articles 26 and 113 TFEU). Since, sustainable development consists of the establishment of a synergy between the economic, environmental and social dimensions of human life in order to move towards a new approach of human progress, by working for the sustainable development of Europe the functioning of the Internal Market is promoted at the same time.

Taking into account the positive impact that the promotion of sustainable development may also have on the functioning of the Internal Market, the study of PPPs as effective public delivery means capable of supporting also sustainable considerations constitutes a research subject with broad, EUbased societal and economic relevance. 
It is also for this reason that this thesis has explored the various strategies, which may enhance, through PPPs, the generation of socio-environmental benefits and, thus, the promotion of sustainable development throughout Europe.

\section{TO WHOM MAY THE RESEARCH RESULTS BE OF INTEREST?}

The research for this thesis has, amongst other matters, provided insight into the legal background of PPPs at an International, European and Member States' level. In that regard, the research results may be employed by various International organizations active in the field of PPPs or by the EU and national legislative bodies which are looking for a uniform or more comprehensive regulation of PPPs, an ambition which is at the forefront of EU policymaking especially following the EU Commission's Communication of 2009 'Mobilizing private and public investment for recovery and long-term structural change: developing Public Private Partnerships' (COM(2009)615final). The thesis identifies, in the absence of an ad hoc and comprehensive PPP's legal regime in most legal systems, the current norms of positive (EU and national) public contracts and concessions law applicable to PPPs. A comprehensive review of their regulation could start from here. Further, the research has discussed the (legal) spaces for sustainable development considerations within EU and national public contracts and concessions laws, which have the potential of allowing PPPs to promote sustainable development through public service and infrastructure delivery. Particular attention may be devoted to such findings in order to shape public contracts' legal regimes to better embed sustainable development concerns.

Besides (EU and national) legislative bodies, there are various other parties and/or institutions to whom the research results may be relevant. First, since the thesis has explored and has identified the various tender and contractual strategies (e.g. defined output specifications, payment mechanism) which can support the generation of socio-environmental benefits through PPPs, the outcomes of the research may be of particular interest for the public and private sectors engaged into innovative and sustainable PPPs. In fact, the thesis clarifies how PPPs can be awarded, structured and managed in a way that allows the promotion of sustainable development gains, along with economic objectives. Second, such a research outcome is relevant also for practitioners and legal experts in the field of complex public contracts. The considerations outlined throughout the research constitute a comprehensible theoretic and practical foundation for practitioners and legal experts whenever they are engaged in the support of the private sector involved in PPP projects. Finally, the thesis, by focusing on a subject (i.e. promotion of sustainable development through PPPs) which until now has not been systematically addressed by scholars and academics in the legal field, provides them with a foundation for further research into the PPP phenomenon as an alternative public service and infrastructure delivery method that can also effectively promote sustainable development considerations. In this regard, various starting points for further and future research are raised throughout the research.

\section{INTO WHICH CONCRETE PRODUCTS, SERVICES, PROCESSES, ACTIVITIES OR COMMERCIAL ACTIVITIES WILL THE RESEARCH RESULTS BE TRANSLATED?}

Firstly, the author's intention is to adapt the thesis into a commercial edition, which is to be marketed by an internationally operating publishing house. This will allow the research results to be properly distributed amongst the various interest groups mentioned under point (2) above (i.e. 
International organizations active in the field of PPPs, legislative bodies, public and private sectors, practitioners and legal experts, (EU) public contracts scholars). By means of the commercial edition, the author intends to maximize the (potential) legal, societal, environmental, economic and academic impact and relevance of the research results.

The thesis identifies various tender and contractual strategies, which can be employed to award and structure PPPs capable of promoting sustainable development. Thus the research results can be employed as guidelines by entrepreneurs and public servants to identify which are - on a case-bycase basis - the most effective strategies which allow socio-environmental considerations to be embedded within PPP structures. Subsequently, award procedures and contractual schemes can be adjusted upon the identified sustainable development considerations. Therefore, by means of the research results, the thesis allows both public and private actors to support the generation of socioenvironmental benefits through PPPs. This will enhance the promotion of sustainable development in the EU. Even though the ultimate decision to translate the research results into concrete adaptations or revisions by current (EU and national) public and private actors remains at their discretion, the thesis has provided them with the essential instruments to do so.

In any case, the research results of the thesis incentivize private entities and civil servants to work together towards a more precise balancing of the economic, environmental and social dimensions of human life.

\section{TO WHAT DEGREE CAN THE RESEARCH RESULTS BE CALLED INNOVATIVE?}

The research results are innovative because PPPs, understood as effective public service and infrastructure delivery means capable of delivering also socio-environmental benefits, have not yet been addressed in a structural or in-depth way by scholars and academics in the legal field - even though the promotion of sustainable development through public procurement represents a pressing current-day challenge within the EU. Thus, the subject matter of the thesis can be regarded as a new research area, which relates to a largely unexplored feature or ability of the PPP phenomenon.

The thesis has unveiled that PPPs are actually capable of promoting sustainable development within the EU if they are effectively shaped upon socio-environmental considerations, from the preprocurement to the maintenance phase. The underlying research processes have, therefore, led to new insights and conclusions which, in conjunction with each other, contribute to a move towards a new understanding of PPPs as effective public delivery means of also socio-environmental benefits (i.e. accelerated and enhanced delivery benefits, wider socio-environmental gains).

\section{HOW WILL THE VALORIZAZION OF THE RESEARCH REUSLTS BE SHAPED?}

As addressed in point (3) above, the author intends to distribute the research results as widely as possible. One intended initiative to this end is the publication of a commercial edition through an internationally operating professional publisher. In addition, the author will be pro-actively involved in (EU) public contracts and focused academic gatherings such as seminars, conferences and symposia. These initiatives will contribute to spread the research results and possibly their translation into concrete guidelines and/or practical handbooks. Further, they will allow the research results to be tested, evaluated and, ultimately, to be supplemented or even revised. This will ensure that the thesis results will effectively contribute to 1) the promotion of sustainable development within the EU through PPPs and 2) the academic progression in the legal field of innovative and complex public contracts. 


\section{CURRICULUM VITAE}

Annalisa Aschieri was born on September 8th, 1988 in Torino. After graduating from high school (Liceo Classico - Collegio San Giuseppe) in 2007, Annalisa earned bachelor and master degrees in Law at the University of Torino, graduating in 2012. During her masters, in 2010, she studied Comparative and International Law at the Centre for Transnational Legal Studies (Georgetown University Law School program) in London and, in 2011, she deepened her knowledge of Comparative and European Law at the Faculty of Law of Maastricht University within an LLP/Erasmus program with the University of Torino. She later graduated in Private Comparative Law magna cum laude at the University of Torino in July 2012 with a thesis drafted entirely in English declared as worth publishing. As of February 2012, Annalisa began practicing law in a renowned Italian law firm in the corporate and M\&A department. She continued to work in the field of company law, national and international contract drafting, both in Italian and in English, at a different law firm based in Torino. In 2014, she entered a joint doctoral research program in European Public Law at the Faculty of Law of the University of Maastricht and University of Torino, engaging in research activities in relation to this dissertation until 2016. At the same time, Annalisa tutored at the Master of Laws (LL.M.) in International Trade Law, Contracts and Dispute Resolution at the International Training Center of the International Labor Organization (United Nations) based in Torino. Annalisa's tutoring tasks were performed in English. In 2017, Annalisa made a career switch as an in-house lawyer specialized in national and international contract drafting, both in Italian and English, at a Torino based company. 